\title{
A PROTEÇÃO JURÍDICA DOS INVESTIMENTOS BRASILEIROS NO EXTERIOR
}

\author{
Dissertação de Mestrado \\ Orientador: Professor Associado Dr. José Augusto Fontoura Costa
}

UNIVERSIDADE DE SÃO PAULO

FACULDADE DE DIREITO

São Paulo - SP

2015 


\section{A PROTEÇÃO JURÍDICA DOS INVESTIMENTOS BRASILEIROS NO EXTERIOR}

Dissertação apresentada à Banca Examinadora do Programa de Pós-Graduação em Direito, da Faculdade de Direito da Universidade de São Paulo, como exigência parcial para obtenção do título de Mestre em Direito, na área de concentração de Direito Internacional e Comparado, sob a orientação do Professor Associado Dr. José Augusto Fontoura Costa.

Versão corrigida em 01 de fevereiro de 2016. A versão original, em formato eletrônico (PDF), encontra-se disponível na CPG da Unidade.

\section{UNIVERSIDADE DE SÃO PAULO \\ FACULDADE DE DIREITO \\ São Paulo - SP




\section{FOLHA DE APROVAÇÃO}

Nome: Gabriel, Vivian Daniele Rocha

Título: A proteção jurídica dos investimentos brasileiros no exterior

Dissertação apresentada à Faculdade de Direito da Universidade de São Paulo para obtenção do título de Mestre em Direito.

Aprovado em:

Banca Examinadora

Prof. Dr. Instituição:

Julgamento: Assinatura:

Prof. Dr. Instituição:

Julgamento: Assinatura:

Prof. Dr. Instituição:

Julgamento: Assinatura: 


\section{AGRADECIMENTOS}

Em primeiro lugar, agradeço aos meus pais Terezinha e Dárcio que, como bons educadores, sempre me inspiraram e me deram o suporte necessário, e nunca deixaram de me apoiar, desde cedo, nos estudos e em minha jornada acadêmica. Ao meu padrinho José Lázaro e às minhas tias Maria Aparecida, Fátima e Bernadete, por todo o carinho e incentivo, que são suas marcas registradas. A Rafael, por todo o carinho e apoio, que me foram tão importantes durante o processo e finalização desta dissertação.

Gostaria de agradecer especialmente ao meu orientador, Professor José Augusto Fontoura Costa, pela oportunidade de orientação séria e precípua, e por todo o solícito e zeloso acompanhamento acadêmico desde o momento em que entrei nas Arcadas.

À minha banca de qualificação, representada pela Professora Michelle Sanchez Ratton Badin, que com suas críticas e reflexões pontuais me fizeram amadurecer as ideias quanto ao tema, e ao Professor Gilberto Bercovici, também pelas observações relevantes apontadas.

À Professora Vera Thorstensen, por todos os ensinamentos e sabedoria diariamente compartilhados no âmbito do comércio internacional, que servem sempre como inspiração à excelência acadêmica e a todos do Centro de Estudos do Comércio Global e Investimento (CCGI/FGV) pela convivência e companheirismo.

Ao Professor Wagner Menezes pelo estímulo à persistência e a nunca desistir de meus objetivos acadêmicos.

À Ligia Veronese, Gabriela Vieira, Mariana Araújo, Talitha Borges, Bárbara Hashimoto Martins, Alexandre Miguel e Bruno Passadore, boas amizades que fiz durante minha vida franciscana no mestrado, e que com certeza fizeram toda a diferença. A Ely Caetano Xavier Júnior, por toda ajuda e conversas elucidativas que tivemos durante a elaboração deste trabalho, que me foram muito esclarecedoras.

Ao terceiro-secretário Pedro Mendonça Cavalcante e a Abrão Árabe Neto, analista de comércio exterior do Ministério do Desenvolvimento, Indústria e Comércio (MDIC), por todos os esclarecimentos acerca do tema, desde à época de Brasília até a véspera da entrega desta dissertação. 
Agradeço também ao terceiro-secretário Leonardo Rocha Bento, pela amizade e a presteza sempre quando necessário, e a todos da Coordenação Geral de Contenciosos (CGC), do Ministério das Relações Exteriores (MRE), por toda a experiência adquirida à época de meu estágio-profissional na CGC, em 2014, em especial ao terceiro-secretário Leandro Rocha de Araújo, por todos os ensinamentos compartilhados, pela parceria e amizade.

Às amigas leais e que sempre estiveram ao meu lado, apoiando este percurso, mesmo em Curitiba, Renata Dal-Prá Ducci e Maria Vitória Costaldello Ferreira.

E a todos que participaram e fizeram diferença de alguma maneira na concretização deste trabalho e em minha vida acadêmica na Velha e Sempre Nova Academia. 
GABRIEL, Vivian Daniele Rocha. A proteção jurídica dos investimentos brasileiros no exterior. 2015. 266 f. Dissertação (Mestrado em Direito) - Faculdade de Direito, Universidade de São Paulo, 2015.

\section{RESUMO}

A regulamentação internacional dos investimentos passa por um contexto de mudanças e, inserido nesse âmbito, encontra-se o Brasil participando ativamente. A mudança de posição brasileira quanto ao regime regulatório dos investimentos será objeto desta dissertação, bem como se o método de solução de controvérsias adotado nos novos acordos brasileiros estimula a negociação entre as partes, em aplicação dos preceitos da teoria da sombra do direito. A análise iniciou-se com a apresentação do regime de proteção internacional dos investimentos e sua evolução e, em seguida, foi descrita a posição do Brasil, que apesar de resistente, tentou adentrar aos acordos de investimento na década de 1990, sem sucesso. Foi demonstrada a atual mudança de paradigma brasileiro, de não mais apenas receptor de investimentos para também investidor e a criação dos Acordos de Cooperação e Facilitação de Investimento que, só em 2015, já foram assinados com 5 países. Descritos o contexto de negociação e as cláusulas materiais do novo acordo, examinou-se os sistemas de solução de controvérsia sobre investimentos existentes, com ênfase na via jurisdicional, pela arbitragem investidor-Estado, consideradas as principais regras e instituições aplicáveis, como o Centro Internacional para Resolução de Disputas sobre Investimentos, entre outros; os sistemas alternativos de solução de controvérsias e os sistemas preventivos de resolução de disputas. Dentro deste estudo, foi trabalhada a teoria da sombra do direito como instrumento para explicar o comportamento dos agentes na negociação na fase pré-contenciosa. Foram analisados os mecanismos de prevenção de controvérsias instituídos nos ACFIs, representados pelo ombudsman ou Pontos Focais e o Comitê Conjunto, e o mecanismo de solução de controvérsias, pela arbitragem entre Estados. No mais, foi estudado o sistema de prevenção e solução de controvérsias sulcoreano, uma vez que o Brasil se inspirou neste para instaurar seu mecanismo preventivo. Assim, feito isso, foi contextualizada a teoria da sombra do direito aos ACFIs, chegando-se ao resultado se a arbitragem entre Estados propugnada estimula ou não a negociação entre as Partes.

Palavras-chave: Acordos de Cooperação e Facilitação de Investimentos (ACFIs). Arbitragem investidor-Estado. Ombudsman. Teoria da sombra do direito. Negociação. 
GABRIEL, Vivian Daniele Rocha. The legal protection of Brazilian investments abroad. 2015. 266 f. Dissertação (Mestrado em Direito) - Faculdade de Direito, Universidade de São Paulo, 2015.

\begin{abstract}
The international investment regulation is changing and Brazil is inserted in this context, participating actively in it. The subject of this dissertation is the change in the Brazilian position on the regulatory regime of investments, as well as if the dispute resolution method adopted in the new Brazilian agreements encourages the negotiation between the parties under the precepts of the theory of the shadow of the law. The analysis started with the introduction of the international protection regime for investments and its evolution. Afterwards, the Brazilian position was described, pointing out that, despite its resistance to the model, the country tried without success to engage itself and subscribe a series of investment agreements during the 1990s. Furthermore, the current transition in the Brazilian investment politics has been demonstrated; hence, the passing from solely position of receptor of investments to a position of an investor as well. In that sense, the importance of the analysis of the creation of the Cooperation Facilitation Investment Agreements, which have been signed with five countries in 2015. Once the negotiation context and the material terms of the new agreement have been described and analyzed, the present work examined the dispute settlement systems on existing investments, specially the judicial process, emphasizing the investor-state arbitration, considered its main rules and institutions such as the International Centre for Dispute Resolution Investment, among others; the alternative systems of dispute resolution; and the preventive dispute resolution systems. Within the study of the preventive dispute resolution systems, the theory of the shadow of the law was conceived as a tool to explain the behavior of the agents while negotiating during the pre-litigation phase. Thus, the dispute prevention mechanisms within the ACFIs - represented by the ombudsman, or Focal Points, and the Joint Committee - and the dispute settlement mechanism - represented by the between States arbitration - have been also analyzed. In addition, the South Korean controversies' prevention and resolution system have been studied, since it has inspired the current Brazilian preventive mechanism. Therefore, the theory of the shadow of the law was adapted to the analyses of the ACFIs, coming to the result if the between State arbitration advocated stimulates or not the negotiations between the Country-parties.
\end{abstract}

Keywords: The Cooperation and Facilitation Investment Agreement (CFIAs). InvestorState arbitration. Ombudsman. The theory of the Shadow of the Law. Negotiation. 


\section{LISTA DE ILUSTRAÇÕES}

Gráfico 1 - Entrada de Investimento Estrangeiro Direto no Brasil (2007-

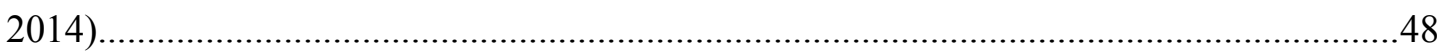

Gráfico 2 - Número de casos registrados nos termos da Convenção CIRDI e das Regras do Mecanismo Complementar por

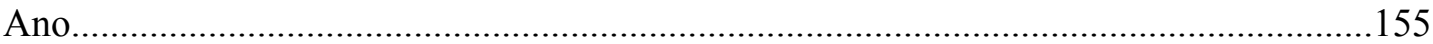

Gráfico 3 - Tipo de casos registrados nos termos da Convenção CIRDI e das Regras do Mecanismo

Complementar.. 156

Gráfico 4 - Controvérsias Resolvidas pelo Sistema Home

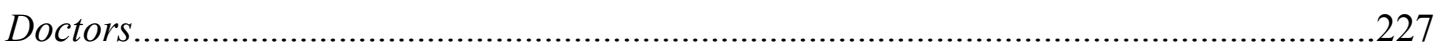




\section{LISTA DE TABELAS}

Tabela 1 - Estoque de Investimentos Diretos do Brasil no Exterior em bilhões (2001-2013).

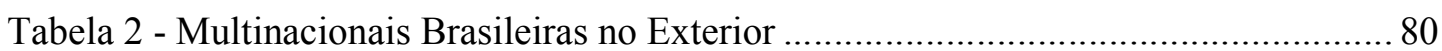

Tabela 3 - Países com Maior Presença de Empresas Brasileiras - 2015 .......................... 82 


\section{LISTA DE ABREVIATURAS E SIGLAS}

ACFI: Acordo de Cooperação e Facilitação de Investimentos

ADCT: Ato das Disposições Constitucionais Transitórias

AGNU: Assembleia Geral das Nações Unidas

AGU: Advocacia Geral da União

AID: Associação Internacional do Desenvolvimento

AII: Acordos Internacionais de Investimento

API: Agência de Promoção de Investimentos

APPRI: Acordo de Promoção e Proteção de Investimentos

BATNA: better alternative to a negotiated agreement

BCB: Banco Central do Brasil

BIRD: Banco Internacional para Reconstrução e Desenvolvimento

BNDES: Banco Nacional para o Desenvolvimento Econômico e Social

BOT: Build-Operate-Transfer

CAFTA-DR: Tratado de Livre Comércio República Dominicana-América Central

CAMEX: Câmara de Comércio Exterior

CBE: Capitais Brasileiros no Exterior

CCE: Câmara de Comércio de Estocolmo

CCI: Câmara de Comércio Internacional

CCJC: Comissão de Constituição e Justiça e de Cidadania

CDEIC: Comissão de Desenvolvimento Econômico, Indústria e Comércio

CFT: Comissão de Finanças e Tributação

CGU: Controladoria Geral da União

CIJ: Corte Internacional de Justiça

CIRDI: Centro Internacional para Resolução de Disputas sobre Investimentos

CMN: Conselho Monetário Nacional

CNI: Confederação Nacional da Indústria

CREDN: Comissão de Relações Exteriores e de Defesa Nacional

CPA: Corte Permanente de Arbitragem

FTA: Free Trade Agreement

GATS: Acordo Geral sobre Comércio de Serviços (General Agreement on Trade in Services) 
GTI: Grupos de Trabalho Interministeriais

ICSID: Centro Internacional para Arbitragem de Disputas sobre Investimentos

IED: Investimento Externo Direto

INPI: Instituto Nacional de Propriedade Intelectual

KOTRA: Korea Trade-Investment Promotion Agency

MAI: Acordo Multilateral sobre Investimentos

MIGA: Multilateral Investment Guarantee Agency

NAFTA: North American Free Trade Agreement

NOEI: Nova Ordem Econômica Internacional

OCDE: Organização para a Cooperação e o Desenvolvimento Econômico

OFIO: Office of the Foreign Investment Ombudsman

OIC: Organização Internacional do Comércio

OMC: Organização Mundial do Comércio

ONU: Organização das Nações Unidas

PBR: Petrobrás Bolivia Refinación SA

RAMC: Regulamento de Arbitragem

RCMC: Regulamento de Conciliação

RDE: Registro Declaratório Eletrônico

RPPA: Regulamento de Produção de Prova Antecipada

SFI: Sociedade Financeira Internacional

SISBACEN: Sistema de Informações do Banco Central

SPE: Special Purpose Entities ou Entidades de Propósito Especial

SUMOC: Conselho da Superintendência da Moeda e do Crédito

SUS: Sistema Único de Saúde

TBI: Tratado Bilateral de Investimentos

TRIMS: Acordo sobre Medidas de Investimentos Relacionadas ao Comércio (Trade Related Measures on Investment)

UNCITRAL: Comissão das Nações Unidas para o Direito Comercial Internacional UNCTAD: United Nations Conference on Trade and Development 


\section{SUMÁRIO}

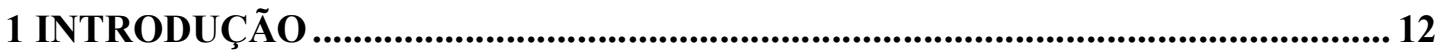

2 O REGIME JURÍDICO DA PROTEÇÃO INTERNACIONAL DOS

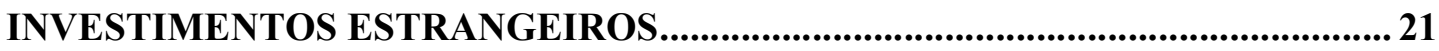

2.1 FORMAÇÃO HISTÓRICA DOS PADRÕES JURÍDICOS DE PROTEÇÃO

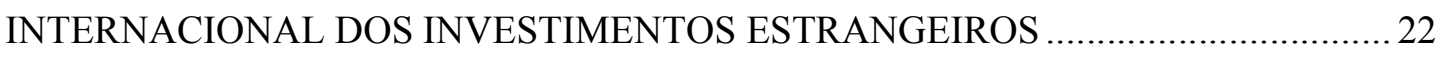

2.2 OS ACORDOS DE PROMOÇÃO E PROTEÇÃO RECÍPROCA DE

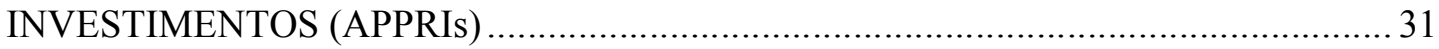

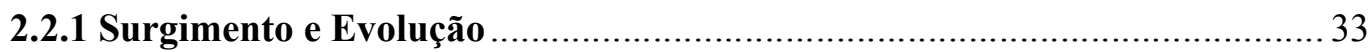

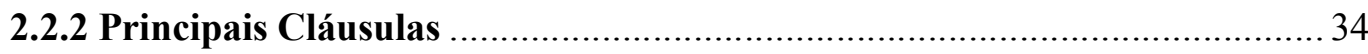

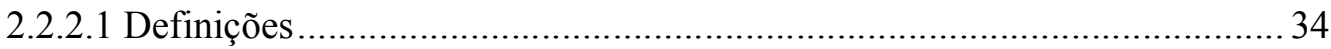

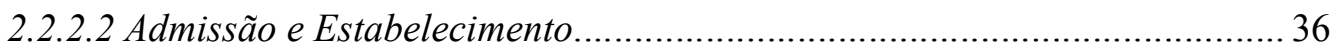

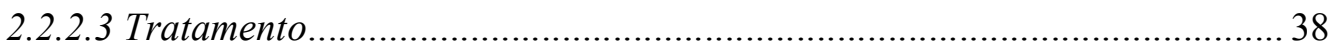

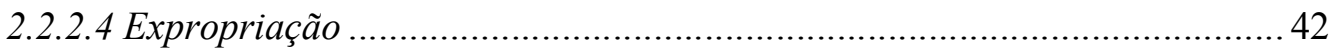

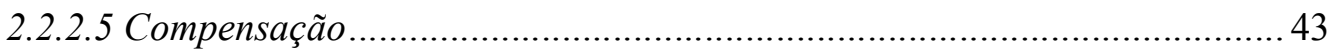

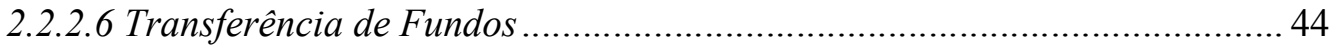

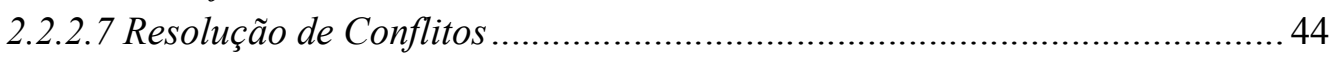

2.3 O BRASIL E O REGIME JURÍDICO DA PROTEÇÃO DOS INVESTIMENTOS

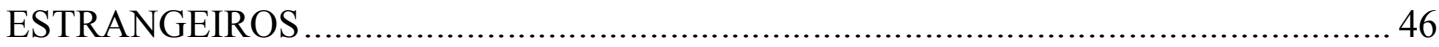

2.3.1 Brasil e o Fluxo de Investimentos Estrangeiros Diretos........................... 47

2.3.2 O Tratado Bilateral de Investimentos Brasileiro na Década de 1990 .......... 49

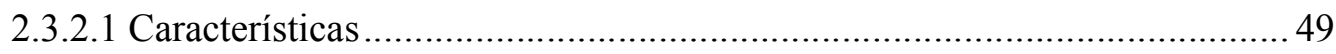

2.3.2.2 A Resistência Brasileira: Fundamentos e Reflexões.................................. 54

2.3.3 As Fontes Internas do Direito dos Investimentos no Brasil ......................... 58

2.3.3.1 Os Investimentos e a Constituição Federal............................................ 58

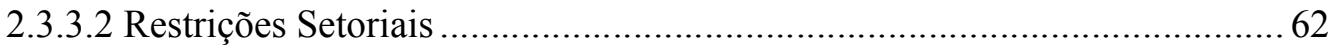

2.3.3.3 Legislação Infraconstitucional Brasileira sobre Investimentos Estrangeiros67

2.3.4 Perfil das Empresas Brasileiras no Exterior.............................................. 76

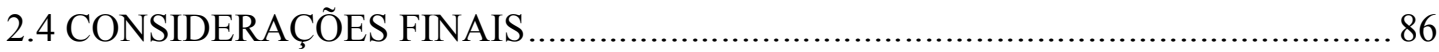

\section{ACORDOS DE COOPERAÇÃO E FACILITAÇÃO DE INVESTIMENTOS}

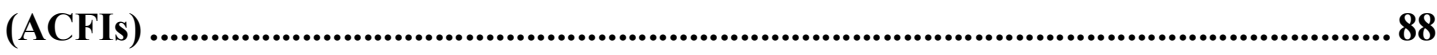

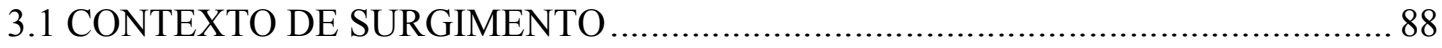

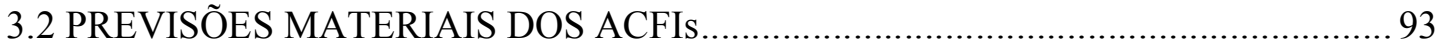

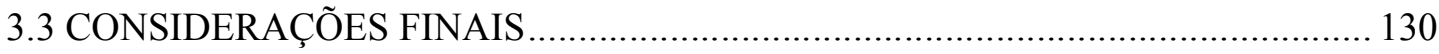

4 SOLUÇÃO E PREVENÇÃO DE CONTROVÉRSIAS SOBRE INVESTIMENTOS 
4.1 MEIOS JUDICIAIS DE SOLUÇÃO DE CONTROVÉRSIAS SOBRE INVESTIMENTOS

4. 1.1 Centro Internacional para Resolução de Disputas sobre Investimentos (CIRDI)

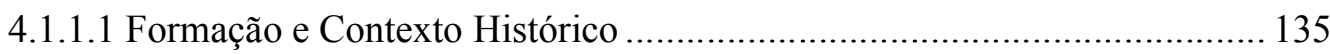

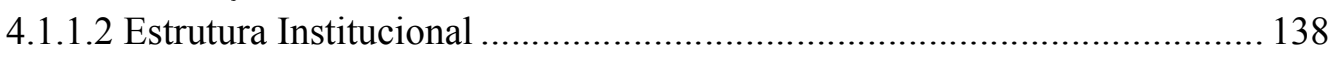

4.1.1.3 Consentimento para Submissão ao CIRDI .......................................... 139

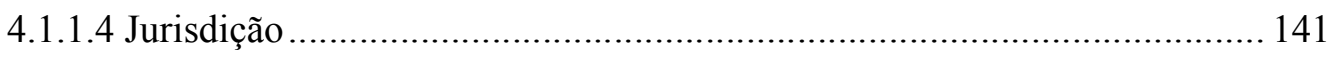

4.1.1.5 Mecanismo Complementar................................................................. 144

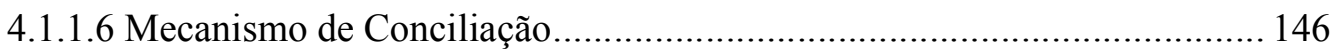

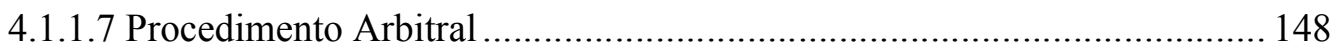

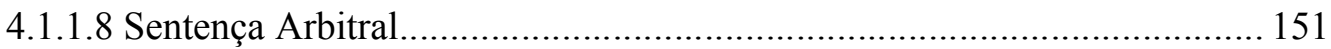

4.1.1.9 Situação Atual e Perspectivas .............................................................. 153

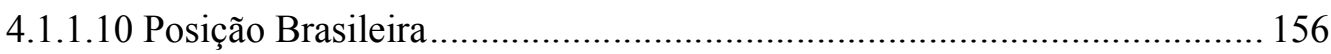

4.1.2 As Regras de Arbitragem da UNCITRAL.............................................. 158

4.1.3 Câmara de Comércio Internacional (CCI) ................................................ 161

4.1.4 Câmara de Comércio de Estocolmo (CCE) ............................................... 162

4.2 A TEORIA DA SOMBRA DO DIREITO E SUA UTILIDADE PARA O DIREITO

4.3 MEIOS ALTERNATIVOS DE SOLUÇÃO DE CONTROVÉRSIAS EM

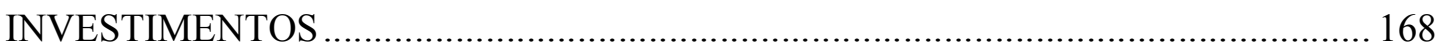

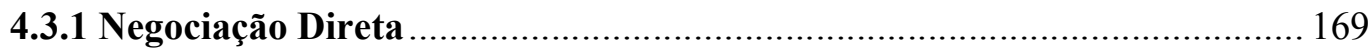

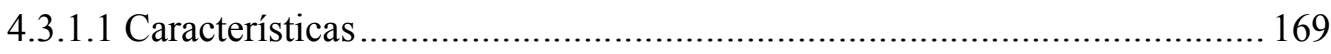

4.3.1.2 Fundamentos da Teoria da Negociação com Base em Interesses.............. 171

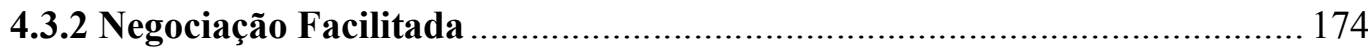

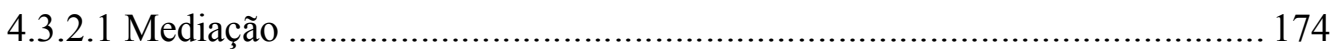

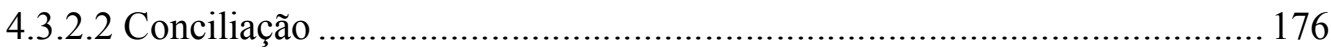

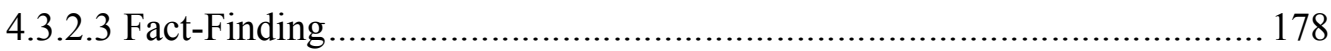

4.4 MEIOS PREVENTIVOS DE SOLUÇÃO DE CONTROVÉRSIAS EM

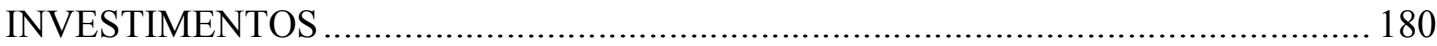

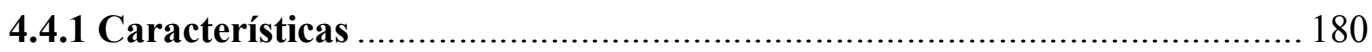

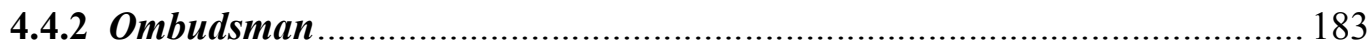

4.4.3 Comissões Interministeriais de Alto Nível ............................................ 187

4.4.4 Prevenção de Controvérsia Setor a Setor ................................................ 188

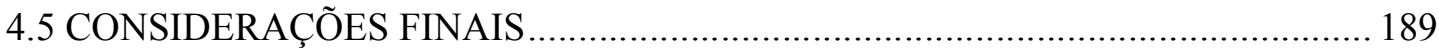

5 OS MECANISMOS DE PREVENÇÃO E SOLUÇÃO DE CONTROVÉRSIAS

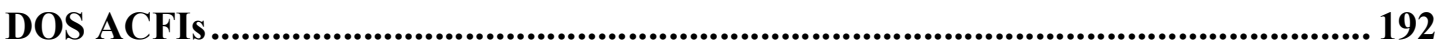

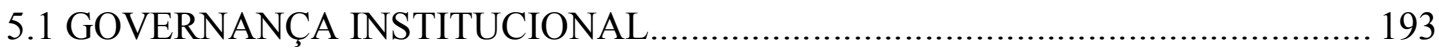

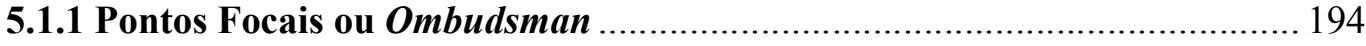

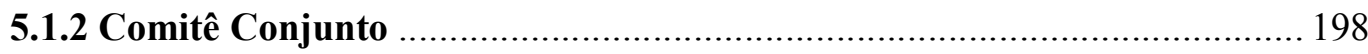

5.1.3 Troca de Informações entre as Partes................................................... 202 
5.1.4 Relação com o Setor Privado.

203

5.1.5 Tratamento da Informação Protegida

5.2 AGENDAS TEMÁTICAS PARA COOPERAÇÃO E FACILITAÇÃO DE INVESTIMENTOS

5.3 PREVENÇÃO DE CONTROVÉRSIAS NOS ACFIs

5.4 SOLUÇÃO DE CONTROVÉRSIAS NOS ACFIs: ARBITRAGEM ENTRE ESTADOS 209

5.5 SOLUÇÃO DE CONTROVÉRSIAS NA COREIA DO SUL 215

5.6 SISTEMA DE PREVENÇÃO E SOLUÇÃO DE CONTROVÉRSIAS DOS ACFIs: CRÍTICAS E REFLEXÕES 221

5.6.1 Legitimidade na Prevenção e Solução de Controvérsias

222

5.6.2 A Aplicação da Teoria da Sombra do Direito na Solução e Prevenção de Controvérsias dos ACFIs 226

5.6.3 A Falta de Coordenação Institucional entre os Mecanismos 231

5.7 CONSIDERAÇÕES FINAIS 233

6 CONCLUSÃO 235 REFERÊNCIAS 


\section{INTRODUÇÃO}

O mundo contemporâneo encontra-se em constante transformação, principalmente, no que tange ao desabrochar de um Direito transnacional ${ }^{1}$ que rege a Novíssima Ordem Internacional ${ }^{2}$. Nesta seara, a empresa multinacional resta-se como a principal agente e força dinâmica ${ }^{3}$ da integração do comércio global e da produção ${ }^{4}$. Expandindo-se em busca de novos mercados em decorrência de fatores competitivos mais favoráveis, como mão de obra menos custosa, o acesso a matérias-primas, a intenção de se evitar a concorrência local e, sobretudo, o propósito de multiplicar seus lucros 5 , a empresa multinacional revela-se como principal investidora estrangeira.

Entretanto, vale destacar que, "à medida que uma firma aumenta seus investimentos, os riscos de incorrer numa dada probabilidade de perda vão se tornando mais sérios" ${ }^{6}$. Com a internacionalização produtiva dessas empresas não é diferente. Nessa esteira, ao se investir em um novo território, os riscos enfrentados vão desde os comerciais, relativos às instabilidades no desenvolver da atividade econômica, até os não comerciais, como no que concerne às instabilidades políticas, decisões arbitrárias e ações governamentais imprevisíveis ${ }^{7}$, consubstanciadas em nacionalizações, expropriações e transferência de controle da propriedade estrangeira, sem compensação, ou, ainda, na obstrução na remessa de valores para os Estados de origem da atividade empresarial estrangeira.

\footnotetext{
${ }^{1}$ Nomenclatura utilizada pelo autor Philip C. Jessup "para incluir todas as normas que regulam atos ou fatos que transcendem as fronteiras nacionais. Tanto o direito público quanto o privado estão compreendidos, como estão outras que não se enquadram inteiramente nessas categorias clássicas". Cf. JESSUP, Philip C. Direito transnacional. Brasil: Editora Fundo de Cultura Brasil Portugal, 1965. p. 12.

${ }^{2}$ RIBEIRO, Marilda Rosado de Sá. Direito dos investimentos e o petróleo. Revista da Faculdade de Direito da UERJ, v. 1, p. 1-37, 2010. p. 05.

${ }^{3}$ FRIEDMAN, Thomas. O mundo é plano: uma breve história do século XXI. Rio de Janeiro: Objetiva, 2005. p. 18.

${ }^{4}$ MUCHLINSKI, Peter. Policy Issues In: MUCHLINSKI, Peter; ORTINO, Federico; SCHREUER, Christoph. (Org.).The oxford handbook of international investment law. Oxford: Oxford University Press, p. 3-48, 2008. p. 11.

${ }^{5}$ BRASIL, Deilton Ribeiro. Empresas transnacionais sob o império da nova ordem mundial e sua integração no direito internacional. Revista dos Tribunais, n. 792, p. 35-62, 2001. p. 50. GÓMEZ-PALACIO, Ignacio; MUCHLINSKI, Peter. Admission and establishment. In: MUCHLINSKI, Peter; ORTINO, Federico; SCHREUER, Christoph. (Org).The oxford handbook of international investment law. Oxford: Oxford University Press, p. 227-258, 2008. p. 233.

${ }^{6}$ PENROSE, Edith. A teoria do crescimento da firma. Campinas: Editora Unicamp, 2006. p. 106.

${ }^{7}$ ZIEGLER, Andreas R.; GRATTON, Louis-Philippe. Investment assurance In: MUCHLINSKI, Peter; ORTINO, Federico; SCHREUER, Christoph. (Org.).The oxford handbook of international investment law. Oxford: Oxford University Press, p. 524-548, 2008. p. 525.
} 
De modo a prover um arcabouço jurídico e institucional mais protetivo e adequado às necessidades dos investidores no plano internacional, surge o Direito Internacional dos Investimentos. Dentre os principais suportes deste sub-ramo do direito encontram-se os acordos de promoção e proteção recíproca de investimentos (APPRIs), instrumentos jurídicos internacionais formados por uma gama de direitos e obrigações, engendrados inicialmente com a finalidade proteger o investidor em território estrangeiro. Entretanto, importante destacar que as disposições previstas nesses instrumentos regulatórios, por abrangerem temas amplos e sensíveis, envolvendo muitas vezes políticas públicas, produzem múltiplos impactos para os atores envolvidos.

Um desses impactos refere-se ao mecanismo de solução de controvérsias estabelecido, visto que, após a Segunda Guerra Mundial, desenvolveu-se no plano internacional a arbitragem investidor-Estado, a qual possibilita o acesso direto do investidor estrangeiro aos tribunais arbitrais internacionais. Por este motivo, atualmente, esta tem sido preferida em detrimento de outros sistemas jurisdicionais de solução de controvérsias, como o judiciário estatal, que muitas vezes é tido como enviesado e pendente aos interesses nacionais do Estado receptor de investimentos, e ao mecanismo da proteção diplomática, muito utilizado até a primeira metade do século XX, contudo, dotado de extremo caráter político, haja vista que se faz necessário passar primeiro pelo crivo do Estado de origem do investidor para que este decida levar a demanda aos foros internacionais.

Nesse sentido, destaca-se que os APPRIs não tiveram a adesão imediata dos Estados. Um dos motivos para tanto foi a alta rejeição do Terceiro Mundo à interferência do capital estrangeiro na soberania dos países recém-independentes provenientes do movimento de descolonização afro-asiáticos, durante as décadas de 1960 e 1970, os quais promoveram, ainda, uma onda de expropriações e nacionalizações contra os investidores ali instalados. No entanto, esse comportamento foi se alterando a partir das décadas seguintes, principalmente, tendo em vista que as nações em desenvolvimento passaram a depender da entrada de capital estrangeiro em seu território para rearranjar suas economias e promover o seu desenvolvimento econômico ${ }^{8}$.

\footnotetext{
${ }^{8}$ UNITED NATIONS CONFERENCE ON TRADE AND DEVELOPMENT. The entry into force of bilateral investment treaties (BITs). IIA MONITOR, n. 3. New York; Geneva: United Nations, 2006, p. 3. Disponível em: $\quad<\mathrm{http}$ //bit.escwa.org.lb/CMSPages/GetFile.aspx?nodeguid=6f33da83-a49d-48fb-8c0da6eec1a0b62e>. Acesso em: 29 jun. 2014.
} 
Apesar disso, alguns Estados permaneceram em condição de resistência, como foi o caso do Brasil. O país manteve-se durante toda a década de 1990 (e assim permanece até os dias de hoje) como um dos maiores receptores de investimentos do mundo. Conforme estima a Confederação Nacional da Indústria (CNI), entre 1990 e 2000, a entrada de IED no Brasil evoluiu de US\$ 208 bilhões para US\$ 1,4 trilhão ${ }^{9}$. Assim sendo, em função de possuir um fluxo de entrada de capitais elevado mesmo sem aderir ao regime regulatório dos investimentos estrangeiros, o Brasil preferiu manter-se afastado desta seara ${ }^{10}$, somando-se a isso, o fato de o país apresentar reticência à Convenção de Washington de 1965, que criou o Centro Internacional para Resolução de Disputas sobre Investimentos (CIRDI), instituição desenvolvida com o objetivo de administrar procedimentos de conciliação e arbitragem entre investidores e Estados, e principal jurisdição para a arbitragem entre investidores e Estados receptores de investimentos.

Ademais, verifica-se que, na década de 1990, o país sinalizou intenções de finalmente aderir ao regime internacional dos investimentos ao assinar 14 tratados bilaterais de investimento, bem como o Protocolo de Colônia, de 1993, e o de Buenos Aires, de 1994, no âmbito do Mercosul, todos versando sobre a proteção e promoção dos investimentos estrangeiros. Todavia, ressalta-se que, apesar dos esforços empregados, nenhum deles foi ratificado pelo Congresso Nacional, o que fez com que o Estado brasileiro retornasse à sua posição de isolamento.

Nesse diapasão, a partir dos anos 2000, o que se constatou foi um fenômeno de avanço progressivo no número de empresas brasileiras internacionalizadas, inclusive, nos mais diversos destinos geográficos, como América Latina, América do Norte, Ásia e África. Entretanto, nem sempre as empresas brasileiras foram bem-recebidas nos outros países, havendo episódios em que estas sofreram graves atentados à sua propriedade ${ }^{11}$, como foi o caso, em 2006, da nacionalização dos ativos da Petrobrás na Bolívia e, em 2008, com a ocupação dos empreendimentos da Odebrecht no Equador, e posterior expulsão da empresa do país.

\footnotetext{
${ }^{9}$ CONFEDERAÇÃO NACIONAL DA INDÚSTRIA. Investimentos estrangeiros diretos no Brasil - 2014 os regimes e políticas de IED: tendências recentes no mundo e no Brasil. Brasília: CNI, 2015. p. 5.

${ }^{10}$ COSTA, José Augusto Fontoura. Proteção internacional do investimento estrangeiro no MERCOSUL. Florianópolis: GEDAI, 2012. p. 21.

${ }^{11}$ RIBEIRO, Marilda Rosado de Sá. Sovereignty over natural resources investment law and expropriation: the case of Bolivia and Brazil. The Journal of World Energy Law and Business, Oxford Journals. v. 2, n. 2, p. 129-148, 2009. p. 132.
} 
Assim sendo, nota-se duas premissas principais: (i) a mudança de posicionamento do Brasil de apenas grande receptor de investimentos, para também investidor e (ii) a posição de vulnerabilidade dos investimentos brasileiros no exterior, frente aos riscos existentes. Diante disso, em 2013, o governo brasileiro iniciou esforços para uma mudança de posição, inclusive, com a participação do setor privado brasileiro, em direção à regulação internacional dos investimentos.

Após realizados os trabalhos para a estruturação de um novo acordo, bem como depois de várias missões comerciais empreendidas à África e à América Latina, foram assinados, em 2015, os Acordos de Cooperação e Facilitação de Investimentos (ACFIs). Estes acordos já foram pactuados com Moçambique, Angola, Malaui, México e Colômbia, havendo a expectativa de que mais acordos sejam firmados em breve.

Nessa esteira, frente à atual mudança da condição do Brasil, que passa de apenas receptor de investimentos estrangeiros, para a condição de investidor e, diante da recente adesão do Brasil ao regime internacional dos acordos de investimentos, a presente pesquisa se justifica em razão da atualidade do tema, de sua importância para o Brasil enquanto política pública e, também, de sua relevância para o Direito Internacional dos Investimentos e para o Comércio Internacional. O novo acordo brasileiro é assinado em um momento de grandes transformações para esse sub-ramo do direito, com a atualização de vários padrões de proteção e a emergência de novas especificidades nos acordos, como por exemplo, o respeito ao desenvolvimento sustentável, a responsabilidade social e corporativa das empresas, as agendas temáticas de cooperação, a priorização dos métodos preventivos de resolução de controvérsias, dentre outros. Além disso, os ACFIs também marcam o reconhecimento pelo Estado brasileiro da necessidade de proteção de seus investidores nacionais no exterior e do auxílio necessário à facilitação de seus investimentos mundo à fora, visto que que muitas vezes estes encontram dificuldades regulatórias e burocráticas em território estrangeiro, o que acaba por dificultar o desenvolvimento de seus investimentos ${ }^{12}$.

Ademais, esses acordos possuem um arcabouço regulatório que mescla os padrões tradicionais de proteção de investimentos com algumas inovações. Dessa forma, o presente estudo fará um exame pormenorizado tanto das previsões materiais do acordo, quanto das

\footnotetext{
${ }^{12}$ PANZINI, Fabrizio; NEGRI, Constanza. O retorno dos acordos de investimentos na agenda comercial brasileira. Revista Brasileira de Comércio Exterior. Rio de Janeiro, ano 29, n. 123, p.58-72, abr.jun. 2015. p.70.
} 
disposições processuais, contudo, a ênfase analítica se centrará nos meios de prevenção e solução de controvérsias instaurados. Essa escolha foi realizada e se justifica também em razão de se ter observado que, apesar de haver um sistema de solução de controvérsias, os ACFIs dão primazia ao alcance de uma solução negociada, que ocorrerá no âmbito dos mecanismos preventivos estabelecidos, quais sejam os Pontos Focais ou ombudsman, e o Comitê Conjunto. Entretanto, questiona-se se em função do mecanismo de solução de controvérsias escolhido (arbitragem entre Estados), mesmo assim haverá estímulos para a negociação, haja vista que o comportamento dos negociadores será distinto daquele exercido quando da arbitragem investidor-Estado.

Nesse ínterim, o objetivo central da presente dissertação reside na análise dos ACFIs, em especial, dos mecanismos de prevenção e de solução de controvérsias adotados pelos acordos, examinando sua sistemática para que se possa chegar à resposta e à conclusão se mesmo diante do método arbitral escolhido há estímulo para a máxima da negociação com base na conciliação dos interesses das partes envolvidas.

Ressalta-se que o trabalho se encontra na fronteira entre o Direito Internacional Público e o Direito Internacional Privado, haja vista que dialoga na realidade com diversas instâncias do Direito. O tema possui enquadramento de Direito Internacional Público ao relacionar-se com outros ramos, como o Direito Administrativo, que visa à proteção do administrado $^{13}$. Além disso, após a Segunda Guerra Mundial a matéria investimentos tornou-se ainda equivalente ao Direito Privado, por abordar elementos do Direito Civil e Direito Comercial, como contratos internacionais, e envolvendo também foros arbitrais de resolução de controvérsia, fortemente utilizados em matéria comercial.

Dentre os objetivos específicos contidos no trabalho, ressaltam-se os de: (i) estabelecer um panorama histórico da evolução do regime da proteção internacional dos investimentos e dos APPRIs, de forma a identificar as previsões de suas principais

13 Nesse diapasão destaca-se a emergência do Direito Administrativo Internacional ou Global. Conforme pontua Marilda Rosado de Sá Ribeiro: “O advento de um Direito Administrativo Global se corrobora a partir da análise do vasto crescimento do alcance e das formas de regulação e administração transgovernamentais, voltadas para as consequências da interdependência globalizada em campos como segurança, assistência financeira a países em desenvolvimento, proteção ao meio-ambiente, regulação financeira e bancária, aplicação efetiva da lei, telecomunicações, comércio de produtos e serviços, propriedade intelectual, standards trabalhistas, e movimentos transfronteiriços de massas, incluindo-se os refugiados. Progressivamente, verifica-se que tais repercussões não podem mais ser tratadas de forma efetiva através de regulação doméstica ou medidas administrativas isoladas”. RIBEIRO, Marilda Rosado de Sá. Direito dos investimentos e o petróleo. Revista da Faculdade de Direito da UERJ, Rio de Janeiro, v.1, n.18, p.1-37, 2010. Assim, esta nova perspectiva do Direito baseia-se na expansão dos regimes regulatórios internacionais, compostos por elementos e funções administrativas. 
cláusulas, bem como descrever a posição do Brasil diante o fluxo do regime internacional dos investimentos estrangeiros, como receptor de investimento e como investidor; (ii) interpretar as disposições materiais presentes nos novos acordos de cooperação e facilitação de investimentos do Brasil e comparar pormenorizadamente as previsões estipuladas nos cinco tratados; (iii) estruturar e descrever os métodos de solução e prevenção de controvérsias sobre investimentos, abarcando os meios judiciais de solução de controvérsias sobre o tema, os métodos alternativos e, por fim, os mecanismos preventivos de solução de controvérsias em investimentos; e (iv) analisar os mecanismos de prevenção e de solução de controvérsias dos ACFIs, examinar, aplicando a teoria da sombra do direito, desenvolvida por Mnookin e Kornhauser ${ }^{14}$, os incentivos para negociação em face do método de solução de controvérsias contido no bojo dos acordos e, conforme o diagnóstico realizado e as considerações que forem extraídas, tecer algumas críticas a respeito dessa sistemática, além de outras críticas acessórias.

Desse modo, ressalta-se que a metodologia empregada no trabalho se baseou, primordialmente, mas não apenas, na pesquisa bibliográfica, a partir da revisão de doutrina e do registro disponível decorrente de pesquisas anteriores. Nessa seara, a pesquisa contou também com um levantamento de fontes primárias, consubstanciadas nos acordos de cooperação e facilitação de investimentos do Brasil, bem como outros tratados de investimentos que foram utilizados quando necessário para melhor elucidar algum dos temas analisados. Por fim, a presente dissertação utilizou-se também da análise de dados emitidos por fontes governamentais, nacionais e internacionais, e fontes privadas, como é o caso dos relatórios da CNI e da Federação das Indústrias do Estado de São Paulo (FIESP).

Assim sendo, ao se descrever resumidamente o escopo dos capítulos da presente dissertação, esclarece-se que o capítulo 2 tratará da formação do regime jurídico de proteção internacional dos investimentos estrangeiros, detalhando a evolução histórica da proteção do investidor, desde os Tratados de Amizade, Comércio e Navegação até a criação e proliferação dos APPRIs. Quanto a estes serão abordadas as eras que simbolizam o desenvolvimento desses acordos, bem como as previsões clausulares que possuem maior incidência nesses tratados. Nesta esteira, será identificada a condição do Brasil frente ao fluxo de investimentos estrangeiros como grande receptor de investimentos. Em seguida, serão examinados os tratados bilaterais de investimentos assinados pelo Brasil na década

\footnotetext{
${ }^{14}$ MNOOKIN, Robert H.; KORNHAUSER, Lewis. Bargaining in the shadow of the laws: the case of
} divorce. Yale Law Journal, v. 88, p. 950-997, 1979. 
de 1990, como tentativa de aderir ao regime regulatório à época, e suas previsões materiais e processuais, além de ser analisada a posição de resistência na aprovação desses documentos pelo Congresso Nacional. Serão relatadas também as fontes internas de regulação do investimento estrangeiro, através das bases constitucionais que abordam o tema e, também, da legislação ordinária, sendo destacadas as restrições setoriais instituídas para os investimentos estrangeiros no país. Por fim, será apresentado o perfil das empresas brasileiras no exterior, tendo sido realizada para tanto uma análise dos dados recentes sobre o fenômeno de internacionalização das empresas brasileiras.

O capítulo 3 terá como foco os Acordos de Cooperação e Facilitação de Investimentos. Primeiramente será descrito o seu contexto de surgimento através da instauração de grupo interministerial com o auxílio do setor privado. Posteriormente, serão examinadas as previsões materiais dos ACFIs, realizando análise comparativa entre as disposições de cada tratado, haja vista que algumas delas diferem de um tratado para o outro. O exame das cláusulas abrangerá os seguintes pontos: (i) o preâmbulo e os objetivos propugnados; (ii) o seu âmbito de aplicação e seus mecanismos de execução; (iii) as definições; (iv) o tratamento outorgado aos investidores e a seus investimentos; (v) as transferências; (vi) a expropriação; (vii) a compensação por perdas; (viii) a transparência; (ix) as exceções visualizadas através de medidas tributárias, medidas prudenciais e exceções de segurança e $(\mathrm{x})$ a responsabilidade social e corporativa.

Em seguida, o capítulo 4 versará sobre os sistemas de solução de controvérsias sobre investimentos. Em primeiro lugar, serão expostos os meios judiciais internacionais de solução de controvérsias sobre o tema, principalmente, através da elucidação da criação, funcionamento e peculiaridades do Centro Internacional para Resolução de Disputas sobre Investimentos, principal instituição que administra controvérsias sobre investimentos. Ademais, serão tratadas também a situação atual do sistema CIRDI e as suas perspectivas, bem como a posição brasileira em relação a ele. Nesse contexto, serão desvendadas também outras regras e instituições para a solução jurisdicional arbitral de disputas sobre investimentos, como as Regras de Arbitragem da UNCITRAL, a Câmara de Comércio Internacional (CCI) e a Câmara de Estocolmo (CCE). Em segundo lugar, abordar-se-ão também os meios alternativos de solução de controvérsias sobre investimentos, consubstanciados pela negociação direta e, neste âmbito, serão elucidados os fundamentos da teoria de negociação com base em interesses e, também, a teoria da sombra do direito, sendo que ambas serão aplicadas no próximo capítulo. Feito isso, tratar-se-á da negociação 
facilitada, sendo especificados os métodos de mediação, conciliação e fact-finding. Finalmente, discorrer-se-á sobre os meios preventivos de solução de controvérsias, suas características e algumas políticas preventivas existentes e escolhidas de acordo com o propósito do trabalho, como o ombudsman, as comissões interministeriais de alto nível e a prevenção de controvérsia setor a setor.

No capítulo 5, será empreendida análise sobre os mecanismos de prevenção e de solução de controvérsias dos ACFIs. Primeiramente, serão examinados os institutos da governança institucional, representados pelos Pontos Focais ou ombudsman, e pelo Comitê Conjunto. Adicionalmente, serão expostas as disposições referentes à troca de informações entre as partes e a relação com o setor privado, as quais se tornam importantes ao passo que corroboram com a facilitação dos investimentos entre as partes. Feito isso, serão abordadas as agendas temáticas de negociação, um dos pilares do acordo, haja vista que estimularão a cooperação entre as Partes. No mais, será explicado o funcionamento do método preventivo de solução de controvérsias, suas fases, os atores legitimados e as especificidades de cada procedimento. O mesmo se fará em seguida com o mecanismo de solução de controvérsias estipulado, qual seja a arbitragem entre Estados, analisando os agentes legitimados e as suas características procedimentais (quando houver). Nesse ínterim, será trazido para análise o sistema de solução de controvérsias da Coreia do Sul, haja vista ter servido como inspiração para o acordo brasileiro, verificando-se o regime regulatório internacional do país asiático e as peculiaridades concernentes à solução de controvérsias em investimentos, bem como fazendo alusão a dados concretos sobre o funcionamento da sistemática preventiva implantada pela Coreia do Sul por meio do ombudsman de investimentos. Por fim, serão empreendidas críticas e reflexões acerca da legitimidade das partes, em especial a do investidor, para acessar tais mecanismos, além disso, do ponto de vista da negociação realizada nas fases pré-contenciosas, será contextualizada a teoria da sombra do direito, sendo esta aplicada primeiramente ao sistema de prevenção e solução de controvérsias sul-coreano, para que depois se possa comparar o resultado desta valoração com a aplicação da mesma teoria para os ACFIs brasileiros. O intuito disso será, portanto, concluir se a arbitragem entre Estados, propugnada nos ACFIs brasileiros, faz com que haja alavancagem na capacidade de as partes negociarem. Por fim, após análise desta sistemática, será estudado também se há ou não coordenação entre os mecanismos preventivos de solução de controvérsias dos ACFIs. 
Assim sendo, ao final, a pesquisa terá a intenção de contribuir de modo efetivo com o estudo do Direito Internacional dos Investimentos e do Comércio Internacional em sua atual conjuntura, com a análise dos novos ACFIs assinados pelo Brasil. Isso se torna importante, ao passo que permitirá o desenvolvimento do estudo da matéria, que é recente, e por isso, ainda se verifica baixa incidência de bibliografia sobre o tema, e a aplicação das teorias de negociação, em especial a teoria da sombra do direito, ao Direito dos Investimentos, para que se possa analisar o comportamento dos agentes durante a negociação, levando em conta o sistema de solução de controvérsias sobre investimentos escolhido. 


\section{O REGIME JURÍDICO DA PROTEÇÃO INTERNACIONAL DOS INVESTIMENTOS ESTRANGEIROS}

Apesar de ser tema recorrente das relações econômicas internacionais, o fluxo internacional de investimentos estrangeiros e sua regulamentação têm sido estudados com mais afinco principalmente após a Segunda Guerra Mundial. Foi a partir desta época que emergiram os primeiros indícios concretos do sistema que se tem atualmente, e que foi lapidado com mais intensidade no final do século XX e início do século XXI. Isto ocorreu, principalmente, em função da intensificação dos tratados internacionais de investimentos, que através de sua estrutura clausular elaboraram uma gama de obrigações com o intuito de prover maior segurança jurídica ao investidor estrangeiro, e da arbitragem investidorEstado, que apesar de não ser o único método, é tido como o sistema mais utilizado para a resolução de disputas sobre o tema.

Outro fator que colaborou para a maior legitimidade do regime jurídico internacional dos investimentos foi a adesão das nações em desenvolvimento a esse sistema, haja vista que inicialmente mostravam-se resistentes a ele, passando a enxergá-lo como ferramenta complementar, porém necessária à atração dos investimentos. Não obstante esse fato, mesmo em se tratando de uma nação em desenvolvimento, o Brasil se mostrou frequentemente relutante a essa sistemática, mesmo porque nunca dependeu destes instrumentos para atrair investimentos para seu território. Entretanto, já no século XXI, passa-se a observar o fenômeno de maior internacionalização das empresas brasileiras, o que começa a despertar inquietações na Academia, no setor privado e no governo acerca da posição brasileira.

Nesse contexto, pretende-se neste capítulo, em primeiro lugar, realizar uma abordagem histórica sobre a formação, a evolução e o conteúdo dos acordos de promoção e proteção recíproca de investimentos, em especial os tratados bilaterais de investimentos, para que se melhor compreenda o escopo desses instrumentos. Posteriormente, o foco se volta para o Brasil, discorrendo-se sobre seu papel como grande receptor de investimentos, bem como as tentativas empreendidas na década de 1990 para aderir ao Direito Internacional dos Investimentos e o porquê essas não alcançaram o sucesso esperado. Em seguida, será examinada a legislação brasileira atinente ao tema investimentos e suas especificidades, o que envolve, dentre outras previsões o tratamento conferido ao investimento estrangeiro em território nacional. Por fim, será analisado o perfil das 
empresas transnacionais brasileiras no exterior, por meio de dados concretos, e como estes investimentos têm sido tratados mais recentemente.

\subsection{FORMAÇÃO HISTÓRICA DOS PADRÕES JURÍDICOS DE PROTEÇÃO INTERNACIONAL DOS INVESTIMENTOS ESTRANGEIROS}

O Direito Internacional dos Investimentos é sub-ramo do Direito Internacional que prevê direitos substantivos e meios procedimentais para se fazerem cumprir os direitos do investidor em contrapartida às ações estatais inconsistentes e prejudiciais a este ${ }^{15}$, sem que se restrinja por completo o policy space do Estado receptor de investimentos. Pretende-se com esta vertente do direito equilibrar da melhor forma possível a relação triangular ${ }^{16}$ entre os Estados (emissor e receptor de investimentos) e o investidor privado, orientada acima de tudo pela segurança jurídica internacional.

Na opinião de Domique Carreau e Patrick Juillard ${ }^{17}$, o Direito Internacional dos Investimentos se apresenta como um prolongamento do direito da condição dos estrangeiros. Contudo, sua cobertura envolve não só a pessoa, mas também os bens do estrangeiro, que são alvo de ações arbitrárias e discriminatórias estatais. Ademais, a regulação e proteção dos investimentos estrangeiros nem sempre foram realizadas da maneira como as conhecemos atualmente, encontrando inicialmente resistência por parte de diversos Estados, que insistiam em manter o tema restrito ao domínio interno de seus territórios.

No plano internacional, a proteção do investidor estrangeiro emergiu, primeiramente, através da adoção de padrões de direito internacional de origem costumeira, como o tratamento justo e equitativo e o da plena e inteira proteção e segurança, que até hoje vigoram e são aplicados diante da ausência de disposições convencionais. Contudo, a partir do momento em que se proliferaram os padrões internacionais de proteção por meio de convenções internacionais, em particular, pelos

\footnotetext{
${ }^{15}$ KOLO, Abba; WÄLDE, Thomas. Capital transfer restrictions under modern investment treaties. In REINISCH, August (Org.). Standards of investment protection. Oxford: Oxford University Press, p.205243, 2008. p. 213.

${ }^{16}$ UNITED NATIONS CONFERENCE ON TRADE AND DEVELOPMENT. International investment agreements: key issues. New York and Geneva: United Nations, 2005. v. 3. p. 2. Disponível em: <http://unctad.org/en/Docs/iteit200410v3_en.pdf>. Acesso em: 30 jun. 2014.

${ }^{17}$ CARREAU, Dominique; JUILLARD, Patrick. Droit international économique. 5. ed. Paris: Dalloz, 2013.
} 
acordos de promoção e proteção de investimentos (APPRIs), a preocupação do Direito dos Investimentos passa a ser prover a melhor utilização desses instrumentos ${ }^{18}$.

A origem dos APPRIs remonta ao século XVII, com o avanço dos Tratados de Amizade, Comércio e Navegação para a proteção de direitos de propriedade dos nacionais dos Estados envolvidos. Esses tratados detinham, dentre suas várias previsões, garantias de padrão de tratamento nacional e da nação mais favorecida ao nacional de uma das Partes que possuísse relações comerciais no território da outra Parte, proteção à propriedade privada, o estabelecimento de comissões de reclamação e, até mesmo, disposições sobre segurança internacional ${ }^{19}$. Dentre esses instrumentos, destaca-se o Tratado de Amizade, Comércio e Navegação celebrado entre Grã-Bretanha e EUA (The Jay Treaty), de 1794, firmado logo após a independência americana, que continha disposições de proteção à propriedade privada e estabelecia comissões de reclamação para determinadas disputas.

Nessa esteira, posteriormente, já no século XIX, a proteção aos investimentos também foi desenvolvida por outro marco, qual seja o regime das capitulações, acordos firmados entre Estados soberanos do Oriente, como China, Egito, Império Turco-Otomano, Pérsia, Japão, entre outros, com Estados ocidentais, que previam privilégios a nacionais destes em território estrangeiro, sem contrapartida em favor dos nacionais de territórios orientais. Dentre as principais previsões estabelecidas, destaca-se a de que quando houvesse qualquer controvérsia envolvendo nacionais de Estados ocidentais em território estrangeiro oriental, a aplicabilidade do Direito do país hospedeiro deveria ser mitigada pela aplicação do direito do Estado de origem do investidor, bem como estes não poderiam ser julgados por cortes nacionais, apenas por juízes de seu Estado de origem. Segundo Antonio Cassese, esses direitos extraterritoriais constituíam sérias restrições à soberania do território estatal ${ }^{20}$.

\footnotetext{
${ }^{18}$ CARREAU, Dominique; JUILLARD, Patrick. Droit international économique. 5.ed. Paris: Dalloz, 2013, p. 432.

${ }^{19}$ Dentre outros exemplos, destaca-se o Acordo de Amizade, Comércio e Navegação entre Grã-Bretanha e Espanha, de 1667, que continha expressa menção de proteção contra a denegação de justiça em casos de prejuízos sofridos por nacionais de um dos Estados Contratantes, assim como garantias de tratamento nacional para nacionais de Estado Contratante engajados em relações comerciais no território da outra Parte e o Tratado de Amizade, Comércio e Navegação entre França e EUA, de 1778, que previa o tratamento da nação mais favorecida, ou seja, que não poderia haver tratamento menos benéfico que o concedido a terceiros nas relações comerciais entre as Partes, no pagamento de direitos ou taxas, assim como haveria a possibilidade de prover segurança militar para os habitantes de ambas as Partes Contratantes. Cf. BROWN, Chester. Introduction: the development and importance of the model bilateral investment treaty In: BROWN, Chester. Commentaries on selected model investment treaties. Oxford: Oxford University Press, 2013. p. 3-6.

${ }^{20}$ CASSESE, Antonio. International Law. 2nd. Oxford: Oxford University Press, 2005. p. 26-28.
} 
Ocorre que, com a revolução industrial e o advento da globalização financeira, observou-se uma intensificação nas relações comerciais, bem como o aparecimento de instituições financeiras especializadas. À época, os empréstimos e a emissão de bônus constituíam as mais relevantes fontes de capital estrangeiro, que eram concentrados, principalmente, na exploração de recursos naturais e, em menor medida, na prestação de serviços públicos.

A exploração dos recursos naturais era frequentemente realizada por meio de concessões públicas por prazos longos (por vezes, estas superavam 100 anos), sem muito controle pelos Estados receptores, que, por seu turno, cobravam royalties calculados conforme a quantidade de bens extraídos. Em certos casos, esses investidores possuíam direitos quase soberanos, "podendo evitar a influência do Estado receptor no território controlado ao mesmo tempo em que se beneficiava das capitulações", o que foi denominado como sistema de enclaves ${ }^{21}$.

Com o fim dos regimes coloniais, a partir do século XIX, estendendo-se ao longo do século XX, proliferou-se uma onda de reações intensas contra as capitulações e os enclaves. Revelava-se um novo panorama mundial, em que Estados recém-independentes, de forma a contrapor seu passado colonial e os resquícios do mesmo, empreenderam diversas tentativas para retomar o controle de sua economia e afirmar sua autonomia política e econômica.

Nesse ínterim, principalmente Estados africanos e asiáticos passaram a refutar certos instrumentos de regulação internacional, considerados como abusivos, e a perceber o capital estrangeiro como violador de sua soberania nacional. Iniciou-se, portanto, uma série de ações que contrapunham o investidor estrangeiro, trazendo-lhe temor e prejuízos, em nome do desenvolvimento nacional dos países receptores, como: (i) a maciça onda de expropriações e nacionalizações, nem sempre seguidas do pagamento das compensações devidas; (ii) a obstrução da remessa de valores dos investidores remetidos para o exterior e (iii) o não pagamento de dívidas contraídas pelos Estados com investidores estrangeiros ${ }^{22}$.

À época, era comum a prática da proteção diplomática - que subsiste até os dias de hoje, mesmo que utilizada em menor frequência -, em que os investidores nacionais,

${ }^{21}$ COSTA, José Augusto Fontoura. Direito Internacional do Investimento Estrangeiro. Curitiba: Juruá, 2010. p. 43.

${ }^{22}$ SCHRIJVER, Nico. Sovereignty over natural resources: balancing rights and duties. Cambridge: Cambridge University Press, 1997. p. 83. GABRIEL, Vivian Daniele Rocha; COSTA, José Augusto Fontoura. O MERCOSUL e as controvérsias sobre investimentos. Revista da Secretaria do Tribunal Permanente de Revisão, Asunción, ano 3, n. 5, p.255-265, 2015. p. 269. 
após o esgotamento infrutífero dos recursos internos do país receptor - seja na esfera administrativa, seja na judicial -, podem reclamar ao seu Estado de origem a violação efetuada pelo Estado receptor. O Estado de origem, por sua vez, decide se acolhe ou não a demanda $^{23}$, e ao optar por amparar seu nacional, eleva a disputa para que esta se resolva entre Estados. Entretanto, ressalta-se que, nesse procedimento, apenas os Estados são os sujeitos legitimados a demandar na esfera internacional, e não o próprio nacional (pessoa física ou jurídica), que é, de fato, o verdadeiro lesado ${ }^{24}$. Assim sendo, neste sistema, o Estado assume a demanda do particular, fazendo-a como se fosse sua ${ }^{25}$.

Destaca-se que em diversas ocasiões a proteção diplomática foi empregada com abusos, mediante uso da força e da violência ${ }^{26}$, principalmente, através da denominada diplomacia das canhoneiras ou gunboat diplomacy. Nesta, portos estrangeiros eram dominados pela Marinha de guerra de países credores, que desejavam forçar o pagamento de suas dívidas.

O caso de maior repercussão foi, sem dúvida, o Incidente de Caracas de 19021903, em que o presidente da Venezuela, Cipriano Castro, negou-se a discutir as dívidas contraídas por seu país com investidores estrangeiros fora do âmbito interno, pois afirmava que, por a matéria ser de cunho estritamente doméstico, deveria, portanto, ser submetida à jurisdição nacional ${ }^{27}$. Em função disso, Alemanha, Itália e Grã-Bretanha bloquearam o Porto de Caracas com suas frotas armadas, impedindo que qualquer navio ingressasse no referido porto e, caso o fizesse, este estaria sujeito a sequestro e julgamento em tribunal de presas marítimas $^{28}$. O imbróglio somente foi resolvido após a interferência dos EUA e o estabelecimento de comissões mistas de arbitragem, com o objetivo de regulamentar os débitos e estruturar os pagamentos devidos. Por fim, a Venezuela acordou em reservar $30 \%$ da arrecadação dos portos de La Guaira e Puerto Cabello para honrar sua dívida.

${ }^{23}$ Conforme afirma Merrils, não há garantia de que o Estado, de fato, irá acolher a demanda e, se assim o fizer, que esta será resolvida de forma pacífica, por negociação ou pressão diplomática, ao invés do sistema judicial de solução de controvérsias internacionais. Cf. MERRILS, J.G. International dispute settlements. 4th. Cambridge: Cambridge University Press, 2005, p.120.

${ }^{24}$ CRAWFORD, James. Brownlie's principles of public international law. 18th. Oxford: Oxford University Press, 2012, p.702-716. GABRIEL, Vivian Daniele Rocha; COSTA, José Augusto Fontoura. O MERCOSUL e as controvérsias sobre investimentos. Revista do Tribunal Permanente de Revisão, Assunción, ano 3, n. 5, p.267-284, 2015. p. 269.

${ }^{25}$ Ressalta-se que essa noção foi afirmada no Mavrommatis, perante a Corte Permanente de Justiça Internacional (CPJI), em 1924, sendo reiterada também nos casos Nottebohn e Barcelona Traction.

${ }^{26}$ MAGALHÃES, José Carlos de. Direito econômico internacional: tendências e perspectivas. Curitiba: Juruá, 2012. p.116.

${ }^{27}$ VIÑUALES, Jorge E.; LANGER, Magnus Jesko. Foreign Investment in Latin-America: between love and Hatred. In: AUROI, Claude (Ed.). Latin-America: dreams and legacy, 2010. Disponível em: $<$ http://ssrn.com/ abstract=1652736>. Acesso em: 3 fev. 2015.

${ }^{28}$ MAGALHÃES, op. cit., p.126-127. 
Contudo, esse sistema de proteção não ficou imune a críticas formuladas à época. A doutrina Drago-Porter, criada pelo Ministro das Relações Exteriores da Argentina Luís Maria Drago e pelo General norte-americano Horace Porter ${ }^{29}$, asseverou que as dívidas ou questões relacionadas à propriedade privada não poderiam ser reavidas por ingerências externas forçosas, condenando o episódio.

Adicionalmente, salienta-se que, desde o século XIX, a doutrina política predominante na América Latina em relação à proteção de investimentos era de oposição à proteção internacional dos investidores. Elaborada pelo argentino Carlos Calvo, em 1868, a doutrina Calvo surgiu em reação aos abusos cometidos pelo exercício da proteção diplomática por Estados Unidos e Europa contra nações latino americanas, em que eram exigidos montantes desproporcionais à reparação de prejuízos causados contra a propriedade de seus investidores nacionais e em algumas ocasiões, tendo sido utilizadas, até mesmo, retaliações econômicas e medidas coercitivas para pressionar o pagamento devido $^{30}$.

A doutrina Calvo tinha como premissa a igualdade jurídica entre nacionais e estrangeiros, pelo que os investidores estrangeiros deveriam seguir o direito interno do Estado receptor, em igualdade de condições aos nacionais daquele país, sem privilégios. Por esse motivo, os estrangeiros deveriam renunciar à proteção diplomática de seu Estado de origem e refutar a utilização de tribunais estrangeiros e arbitrais, visto que não poderiam deter proteção mais elevada que a proporcionada ao nacional do Estado receptor, utilizando das cortes nacionais deste ${ }^{31}$. Também os Estados soberanos deveriam afastar a interferência de outros governos (a exemplo da gunbolt diplomacy) e se absterem da

\footnotetext{
${ }^{29}$ Ressalta-se que o general Porter foi defensor dessa posição na ocasião da III Conferência Pan-Americana, realizada no Rio de Janeiro, em 1906. Cf. CERVO, Amado Luiz; BUENO, Clodoaldo. História da política exterior do Brasil. Brasília: UNB, 2008. p.179.

${ }^{30}$ CALVO, Carlos. Derecho Internacional teórico y prático de Europa y América. Paris: Durand et Pedone-Lauriel, $1868 . \quad$ t.1. $\quad$ Disponível em: $<$ https://books.google.com.br/books?id=KsBBAAAAYAAJ\&printsec=frontcover\&hl=pt$\mathrm{BR} \&$ source $=\mathrm{gbs}$ ge_summary_r\&cad $=0 \# \mathrm{v}=$ onepage\&q\&f=false $>$. Acesso em: 4 out. 2015. LEVY, Daniel de Andrade; MOREIRA, Rodrigo. ICSID in Latin America: where does Brazil stand? In: LEVY, Daniel de Andrade; BORJA, Ana Gerdau de; PUCCI, Adriana Noemi. Investment protection in Brazil. Alphen aan de Rijn: Wolters Kluwer, p.17-36, 2013. p.17-18. XAVIER JÚNIOR, Ely Caetano. Direito internacional dos investimentos e o Brasil: uma perspectiva a partir do padrão de tratamento justo e equitativo. 2014. 279 f. Dissertação (Mestrado em Direito) - Faculdade de Direito da Universidade Estadual do Rio de Janeiro, Rio de Janeiro, 2014. p.110.

${ }^{31}$ RIBEIRO, Marilda Rosado de Sá Ribeiro. As empresas transnacionais e os novos paradigmas do comércio internacional. In: DIREITO, Carlos Alberto Menezes; TRINDADE, Antonio Augusto Cançado; PEREIRA, Antonio Celso Alves (Org.). Novas perspectivas do direito internacional contemporâneo: estudos em homenagem ao professor Celso D. de Albuquerque Mello. Rio de Janeiro: Renovar, p.455-492, 2008. p.488. COSTA, José Augusto Fontoura. Direito internacional do investimento estrangeiro. Curitiba: Juruá, 2010. p.62.
} 
obrigação de pagar compensação por danos sofridos por investidores estrangeiros em razão de guerras civis ou distúrbios internos, a não ser que houvesse lei interna prevendo tal obrigação ${ }^{32}$.

Entretanto, como bem salienta a professora Marilda Rosado de Sá Ribeiro "teorias tradicionais de proteção diplomática e responsabilidade do Estado passaram a ser confrontadas, na segunda metade do século XX, com o princípio da soberania permanente sobre os recursos naturais, riqueza e atividades econômicas" ${ }^{\prime 3}$. A ideia de soberania permanente dos recursos naturais é discutida desde a década de 1950, em particular, pelas nações em desenvolvimento, "como uma garantia legal para evitar a violação de sua soberania econômica em virtude de direitos contratuais ou do direito de propriedade reclamado por outros Estados ou por companhias estrangeiras" ${ }^{\text {34 }}$.

Por intermédio dos trabalhos da Comissão para a Soberania Permanente sobre os Recursos Naturais, de iniciativa da Comissão de Direitos Humanos da ONU, e da Resolução 626 (VII) da Assembleia Geral das Nações Unidas (AGNU), de 1952, aventouse a questão da contrariedade dos países terceiro-mundistas à internacionalização do controle dos recursos naturais. O tema guarda relação umbilical com pontos controversos sobre expropriações de propriedade estrangeira, compensação e tratamento do investimento estrangeiro, os quais estiveram no centro de várias crises internacionais entre nações desenvolvidas e subdesenvolvidas ${ }^{35}$. Ademais, já na década de 1960, a Resolução 1803 (XVII) da AGNU, de 1962, sobre a Soberania Permanente sobre Recursos Naturais, veio reafirmar o debate aduzindo que a exploração, desenvolvimento e disposição dos recursos naturais e a importação dos investimentos estrangeiros necessários para tais finalidades deveriam estar em consonância com os regulamentos e condições que as nações do Terceiro Mundo considerassem necessárias ou desejáveis à autorização, restrição ou proibição de tais atividades.

Na década de 1970, destaca-se a emergência da Nova Ordem Econômica Internacional (NOEI), marcada pela oposição de interesses entre países em desenvolvimento e desenvolvidos e, consequentemente, entre Estados receptores de

32 SCHRIJVER, Nico. Sovereignty over natural resources: balancing rights and duties. Cambridge: Cambridge University Press, 1997. p.178.

${ }^{33}$ RIBEIRO, Marilda Rosado de Sá. Direito dos investimentos e o petróleo. Revista da Faculdade de Direito da UERJ, Rio de Janeiro, v.1, n.18, p.1-37, 2010. p. 2.

${ }^{34}$ BERCOVICI, Gilberto. Direito econômico do petróleo e dos recursos minerais. São Paulo: Quartier Latin, 2011. p. 43.

${ }^{35}$ BERCOVICI, Gilberto op. cit., loc. cit. 
investimentos e investidores ${ }^{36}$. Os preceitos da NOEI aduziam que os Estados em desenvolvimento deveriam legitimamente utilizar todos os seus recursos à causa do desenvolvimento, e isso deveria ser realizado através de esforços da própria nação e de seus governantes ${ }^{37}$, além disso, o controle dos investimentos estrangeiros competia aos Estados receptores, inclusive com a submissão à legislação e aos judiciários domésticos ${ }^{38}$.

Importante destacar também, que após a Segunda Guerra Mundial predominou-se a prática dos contratos com o Estado, em particular na seara da exploração dos recursos naturais e da oferta de serviços públicos. Tais contratos envolvem uma parte privada estrangeira de um lado, e o Estado ou pessoa jurídica de direito público de outro ${ }^{39}$, “implicando muitas vezes, mas não todas, um investimento estrangeiro direto" ${ }^{40}$. Contudo, com o aumento do fluxo comercial e de investimentos, fez-se necessário também o aumento da proteção ao investidor, com níveis de proteção maiores que os conferidos pelo direito nacional estatal. Assim se procedeu a internacionalização do contrato com o Estado, dando-lhes foros de Direito Internacional, além das demais consequências dessa internacionalização.

Conforme pontua Hermes Marcelo Huck, esses contratos apresentam as seguintes características: (i) característica política, relacionada com o interesse público nacional do Estado; (ii) mutabilidade essencial, havendo possibilidade de alteração ou rescisão unilateral pelo Estado (justificável pela utilidade ou interesse públicos, seguida de

${ }^{36}$ TOURME-JOUANNET, Emmanuelle. What is a fair international society? International law between development and recognition. Oxford and Portland: Hart Publishing, 2013. p. 19. FEUER, Guy; CASSAN, Hervé. Droit international du développement. 2. ed. Paris: Dalloz, 1991.

${ }^{37}$ CANÇADO TRINDADE, Antonio Augusto. As Nações Unidas e a Nova Ordem Econômica Internacional (com atenção especial aos Estados latino-americanos). Revista de Informação Legislativa, Brasília, ano 21, n. 81, p.213-232, jan./mar. 1984. p. 214. MAGALHÃES, José Carlos de. Direito econômico internacional: tendências e perspectivas. Curitiba: Juruá, 2012. p. 89-90.

${ }^{38}$ Nessa esteira, a NOEI foi solidificada através de três resoluções no âmbito da AGNU: (i) Declaração para o Estabelecimento de uma Nova Ordem Econômica Internacional - Resolução 3.201(S-VI) da AGNU (maio de 1974); (ii) Programa de Ação para o Estabelecimento de uma Nova Ordem Econômica Internacional - Resolução 3.202 (S-VI) (maio de 1974) e (iii) Carta de Direitos e Deveres Econômicos dos Estados - Resolução 3.281 (XXIX) da AGNU (dezembro de 1974). Dentre os direitos afirmados por esses documentos, destaca-se que a Resolução 3.202 aduzia que o princípio da nacionalização aduzia que cada Estado estaria autorizado a determinar o montante de compensação ao investidor e a forma de pagamento, e se houvesse algum litígio, este deveria ser resolvido com respaldo na legislação nacional do Estado receptor. Além disso, a Carta de Direitos e Deveres Econômicos dos Estados, estabeleceu uma gama de princípios a reger as relações econômicas ente as nações, tal como o da igualdade soberana, e os deveres econômicos dos países e a responsabilidade destes na seara internacional. Quanto à expropriação estabeleceu-se o pagamento de indenização adequada, conforme as leis domésticas e às circunstâncias julgadas pertinentes pelo Estado, afastando qualquer referência ao Direito Internacional. Cf. CANÇADO TRINDADE, Antonio Augusto. Op.cit. p. 215.

${ }^{39}$ HUCK, Hermes Marcelo. Contratos com o Estado: aspectos de Direito Internacional. São Paulo: Editora Aquarela, 1989. p.11-12

${ }^{40}$ COSTA, José Augusto Fontoura. Direito internacional do investimento estrangeiro. Curitiba: Juruá, 2010. p.116. 
compensação); (iii) longa duração, haja vista que longos projetos requerem longos prazos; (iv) previsão de cláusula de arbitragem, prática frequente nos contratos internacionais; e (v) previsão de cláusula de estabilização, que de acordo com o autor, vem sendo cada vez menos utilizada ${ }^{41}$. Desse modo, a internacionalização do contrato com o Estado passou a elevar o nível de proteção dos investidores estrangeiros, auxiliando na sedimentação do caminho para a arbitragem investidor-Estado e a construção das cláusulas dos tratados, em especial no que concerne às atividades com o setor público ${ }^{42}$.

Contudo, desde a nacionalização petrolífera dos ativos britânicos pelo Irã (Anglo Iranian Oil Company), em 1951, as expropriações das concessões Liamco na Líbia, em 1955, e a nacionalização do Canal de Suez (Suez Canal Company) pelo Egito, em 1956, e com o auge das expropriações na década de $1970^{43}$, o cenário internacional permaneceu em alerta. A partir de então, iniciaram-se tentativas internacionais para engendrar uma nova arquitetura jurídica e institucional para tratar da matéria investimentos e para proteger o investidor ${ }^{44}$.

Foram empreendidos esforços para o estabelecimento de um acordo multilateral sobre investimentos para que instituísse um padrão multilateral de tratamento e proteção aos investidores. Dentre as principais iniciativas, salienta-se a Carta de Havana, de 1948, e sua tentativa de instauração da Organização Internacional do Comércio (OIC) $)^{45}$, em que era previsto no documento o tratamento do tema investimentos nos artigos 11 e 12 . Outra proposição de delinear um acordo para a proteção de investimentos estrangeiros foi a da Câmara de Comércio Internacional (CCI) de Paris, em 1949, denominado Projeto de

${ }^{41}$ HUCK, Hermes Marcelo. Contratos com o Estado: aspectos de Direito Internacional. São Paulo: Editora Aquarela, 1989. p. 32-33.

${ }^{42}$ COSTA, José Augusto Fontoura. Direito internacional do investimento estrangeiro. Curitiba: Juruá, 2010. p. 123.

${ }^{43} \mathrm{Na}$ década de 1970, diversos casos de desapropriação tomaram lugar, como a nacionalização da indústria petrolífera na Líbia e no Kuwait, a nacionalização das minas de cobre no Chile, a expulsão das empresas exploradoras de bauxita na Jamaica, além do advento da Revolução Iraniana de 1979 e a expulsão das empresas estrangeiras investidoras do país, pelo que, em razão da última, foi instituído o Tribunal de Reclamações Irã-Estados Unidos. Cf. TELLI, Isadora Postal. Investimento estrangeiro e meio ambiente: uma análise sobre o tratamento das questões ambientais suscitadas nos casos decididos pelo ICSID entre 2000-2013. 2015. 188 f. Dissertação (Mestrado em Direito) - Faculdade de Direito da Universidade de São Paulo, São Paulo, 2015. p. 46.

${ }^{44}$ RIBEIRO, Marilda Rosado de Sá; XAVIER JÚNIOR, Ely Caetano. Introdução. In: RIBEIRO, Marilda Rosado de Sá. Direito Internacional dos Investimentos. Rio de Janeiro: Renovar, p. 1-7, 2014. p. 1.

${ }^{45}$ LAFER, Celso. O GATT, a cláusula da nação mais favorecida e a América Latina. Revista de Direito Mercantil, Industrial, Econômico e Financeiro, São Paulo, v. 10, n.3, p.41-56, 1971. p. 43. THORSTENSEN, Vera. OMC Organização Mundial do Comércio: As regras do comércio internacional e a nova rodada de negociações multilaterais. São Paulo: Aduaneiras, 2001. p.30-31. ZERBINI, Eugenia C.G. de Jesus. Regras multilaterais sobre o investimento internacional. In: AMARAL JÚNIOR, Alberto do; SANCHEZ, Michelle Ratton (Coord.). Regulamentação internacional dos investimentos: algumas lições para o Brasil. São Paulo: Aduaneiras, p. 125-149, 2007. p. 126-127. 
Código Internacional para o Tratamento Justo do Investimento Estrangeiro. Por fim, mas não menos importante, houve também o Projeto Ab-Shawcross ou Projeto da Convenção sobre Investimentos Estrangeiros, de 1959, realizado no âmbito da Organização para a Cooperação e Desenvolvimento Econômico (OCDE) $)^{46}$, considerado relevante precedente ao arcabouço dos direitos, obrigações e procedimentos presentes nos futuros APPRIs.

Ocorre que nenhuma dessas iniciativas progrediu. O sistema multilateral do comércio voltou a tratar do tema à época da Rodada do Uruguai (1986-1994), quando da formulação do Acordo Geral sobre Comércio de Serviços (em inglês, GATS ${ }^{47}$ ), em que na modalidade 3 (presença comercial) englobou-se a liberalização do investimento estrangeiro como qualquer tipo de estabelecimento, constituição, aquisição e manutenção de pessoa jurídica, bem como criação ou manutenção de uma divisão ou representante com fins de prestar um serviço no exterior, sendo garantidos direitos de transparência, notificação, tratamento da nação mais favorecida, acesso a mercados, subsídios e restrições ao câmbio. Outro acordo realizado neste âmbito foi o Acordo sobre Medidas de Investimentos Relacionadas ao Comércio (em inglês, $\mathrm{TRIMS}^{48}$ ), que tem como principal escopo banir medidas relacionadas ao comércio que sejam incompatíveis com obrigações de tratamento nacional e de proibição a medidas de restrições quantitativas, sendo as mais importantes as de exigência de conteúdo local e as que requerem desempenho nas exportações ${ }^{49}$.

Apesar de não consistir em tratado multilateral que regule a matéria investimentos, uma iniciativa que se mostrou benéfica foi a criação da Agência Multilateral de Garantia de Investimentos (em inglês, Multilateral Investment Guarantee Agency - MIGA). Estabelecida no âmbito do Banco Mundial, esta visa fornecer seguros contra riscos políticos aos investidores, prover assistência técnica a países em desenvolvimento para criar um clima favorável à atração de investimentos e mediar disputas sobre investimentos no caso de concedidas as garantias ao investidor.

${ }^{46}$ BROWN, Chester. Introduction: the development and importance of the model bilateral investment treaty In: BROWN, Chester. Commentaries on selected model investment treaties. Oxford: Oxford University Press, p. 1-13, 2013. p. 6-7. PARRA, Antonio. The history of ICSID. Oxford: Oxford University Press, 2012. p. vii e p.14. ZERBINI, Eugenia C.G. de Jesus. Regras multilaterais sobre o investimento internacional. In: AMARAL JÚNIOR, Alberto do; SANCHEZ, Michelle Ratton (Coord.) Regulamentação internacional dos investimentos: algumas lições para o Brasil. São Paulo: Aduaneiras, p.125-149, 2007. p. 126-127. SORNARAJAH, M. The International Law of Foreign Investment. 3rd. New York: Cambridge University Press, 2010. p.79-80.

${ }^{47}$ No original General Agreement on Trade in Services.

${ }^{48}$ No original, Trade Related Measures on Investment.

49 THORSTENSEN, Vera. OMC Organização Mundial do Comércio: As regras do comércio internacional e a nova rodada de negociações multilaterais. São Paulo: Aduaneiras, 2001. p. 105. 
No plano regional, destaca-se o advento da regulamentação do North American Free Trade Agreement (NAFTA) sobre investimentos, prevista no capítulo 11 do acordo. Esses dispositivos se assemelham aos dos tratados de investimentos americanos, de cunho liberalizante e oferecendo um sistema de solução de controvérsias investidor-Estado aos países do bloco. Outra iniciativa que merece destaque é a Carta da Energia (em inglês, Energy Charter Treaty), acordo setorial, que também detém previsões sobre investimentos, bem como um mecanismo de solução de controvérsias para disputas relacionadas à matéria energética.

Diante da ausência de tratado multilateral de investimentos, foram criados instrumentos específicos para que o tema pudesse ser regulado no plano internacional. Estes são os acordos de promoção e proteção recíproca de investimentos, que detêm tanto direitos substantivos, quanto processuais, com acesso a mecanismos para dirimir eventuais $\operatorname{disputas}^{50}$.

Assim, o Direito dos Investimentos desenvolveu-se através de seus dois pilares: (i) os acordos de promoção e proteção de investimentos, em especial os tratados bilaterais de investimento (TBIs), que serão abordados neste capítulo e (ii) a arbitragem mista investidor-Estado, que será examinada de forma mais aprofundada no capítulo 4. Portanto, criou-se um arranjo institucional que pudesse instituir proteção aos investidores estrangeiros e, ao mesmo tempo, harmonizar seus objetivos de promoção e facilitação dos investimentos, acrescido de um mecanismo de solução de controvérsias descentralizado e independente de qualquer organismo estatal ou supranacional, com base no direito privado e de caráter arbitral ${ }^{51}$.

\subsection{OS ACORDOS DE PROMOÇÃO E PROTEÇÃO RECÍPROCA DE INVESTIMENTOS (APPRIs)}

\footnotetext{
${ }^{50}$ Salienta-se que, durante os anos 1990, a OCDE realizou uma nova tentativa para desenvolver um instrumento multilateral vinculante para proteção e liberalização dos investimentos estrangeiros. Foi criado o Acordo Multilateral sobre Investimentos (em inglês Multilateral Agreement on Investment MAI), inspirado principalmente no Capítulo 11 do North American Free Trade Agreement (NAFTA) e nos acordos de investimentos mais liberais. Entretanto, este não alcançou sucesso, em razão de sua estrutura extremamente protetiva dos investimentos, da falta de participação dos grupos de pressão no desenvolvimento do acordo e da falta de consenso entre os próprios membros da OCDE.

${ }^{51}$ RIBEIRO, Marilda Rosado de Sá; XAVIER JÚNIOR, Ely Caetano. Introdução. In: RIBEIRO, Marilda Rosado de Sá. Direito Internacional dos Investimentos. Rio de Janeiro: Renovar, p.1-7, 2014. p. 7.
} 
Apesar das tentativas de se implementar um acordo multilateral sobre investimentos, bem como dos esforços para a formação de um Direito Internacional do Desenvolvimento, o modo mais efetivo de se regular os investimentos estrangeiros no âmbito internacional se deu através dos acordos de promoção e proteção recíproca de investimentos, especialmente em sua espécie bilateral.

Esta nova fase do Direito Internacional dos Investimentos foi inaugurada a partir da assinatura do primeiro tratado bilateral de investimento entre Alemanha e Paquistão, em 1959, que entrou em vigor em 1962. Dentre as motivações existentes para o acordo, Kenneth Vandevelde destaca que, após ter perdido seus investimentos estrangeiros como resultado direto da Segunda Guerra Mundial, o Estado alemão encontrava-se em situação especialmente sensível quanto aos riscos políticos a que seus investidores estavam expostos, por isso, a adoção destes instrumentos jurídicos internacionais para tentar amparar os investidores alemães ${ }^{52}$.

Os objetivos centrais desses tratados, segundo Salacuse e Sullivan, são: (i) a promoção, ou seja, o fomento de mais investimentos; (ii) a proteção, que se refere ao amparo ao investidor no caso de ações soberanas que possam interferir em seus direitos de propriedade ou no desenrolar de suas atividades em território estrangeiro e (iii) a liberalização, que se propõe a facilitar a entrada e a operação dos investimentos no Estado receptor $^{53}$.

Apesar de os tratados serem similares entre si $^{54}$, cada Estado normalmente possui seu acordo específico de investimento, variando conforme a intenção das partes e adotando padrões ora mais liberalizantes, ora mais protetivos e cooperativos à promoção dos investimentos ${ }^{55}$. Nesse sentido, passa-se à análise do surgimento e evolução dos TBIs segundo o marco teórico de Kenneth Vandevelde e das principais cláusulas-base presentes nesses tratados e suas especificidades.

\footnotetext{
${ }^{52}$ VANDEVELDE, Kenneth J. A brief history of international investment agreements, U.C. Davis Journal of International Law \& Policy, California, v. 12, n. 1, p.157-194, 2005. p. 169.

${ }^{53}$ SALACUSE, Jeswald W.; SULLIVAN, Nicholas P. Do bits really work?: an evaluation of bilateral investment treaties and their grand bargain. Harvard International Law, Cambridge, v. 46, n. 1, Winter 2005.

${ }^{54}$ SORNARAJAH, M. The international law on foreign investment. New York: Cambridge University Press, 1994, p. 237. NEUMAYER, Eric, SPESS, Laura. Do bilateral investment treaties increase foreign direct investment to developing countries? London: LSE Research Online, 2005, p. 3. Disponível em: <http://eprints.lse.ac.uk/archive/00000627>. Acesso em: 2 mai. 2013.

${ }^{55}$ KLOSS, Karla. Investimentos estrangeiros: regulamentação internacional e acordos bilaterais. Curitiba: Juruá, 2010. p. 53.
} 


\subsubsection{Surgimento e Evolução}

Para Kenneth Vandevelde existem três eras que simbolizam o desenvolvimento dos tratados de promoção e proteção de investimentos: (i) a Era Colonial; (ii) a Era PósColonial e (iii) a Era Global. A primeira delas consiste na proteção dos investimentos antes da Segunda Guerra Mundial, em que a principal maneira de se resguardar internacionalmente os investimentos se dava por meio do direito internacional costumeiro e, também, pelos tratados de Amizade, Comércio e Navegação. A segunda era consiste no período pós-guerra, assinalado pelos processos de liberalização econômica, de descolonização afro-asiática e de massivas expropriações do setor privado por países terceiro-mundistas. Em razão disso, nessa época, as nações desenvolvidas, pressionadas pelo lobby de suas firmas internacionais, responderam às ameaças enfrentadas criando os TBIs, que foram firmados, sobretudo, com os Estados subdesenvolvidos.

Por fim, o terceiro período inicia-se no final dos anos 1980, a partir de uma mudança no contexto internacional de negociação desses acordos, com o abandono da hostilidade dos países em desenvolvimento a esses instrumentos jurídicos internacionais, e seu ânimo em atrair capital provendo um ambiente mais seguro para os investidores, o que acarretou em um race-to-the-bottom para a atração de investimentos em direção a esses países e na explosão do número de TBIs firmados e ratificados na época ${ }^{56}$.

Outrossim, a partir do final dos anos 1990, verifica-se que os países em desenvolvimento iniciaram esforços mais proativos em pactuar tratados bilaterais de investimentos entre eles mesmos. Elkins, Guzman e Simmons afirmam que estes devem envolver no mínimo um país com considerável aporte de capital, para que o instrumento não esteja fadado à irrelevância por não haver capital suficiente na relação para que uma

\footnotetext{
${ }^{56}$ Ressalta-se que, até 1990, o número de tratados em vigor era de 355. Já em 2000, esse número evoluiu para 1633. Segundo o Investment Policy Hub da UNCTAD, em 2015 já são 2285 tratados bilaterais de investimento em vigor. Cf. UNITED NATIONS CONFERENCE ON TRADE AND DEVELOPMENT. The entry into force of bilateral investment treaties (BITs). IIA MONITOR, n. 3. New York; Geneva: United Nations, 2006, p. $3 . \quad$ Disponível em: $<$ http://bit.escwa.org.lb/CMSPages/GetFile.aspx?nodeguid=6f33da83-a49d-48fb-8c0d-a6eec1a0b62e>. Acesso em: 29 jun. 2014. UNITED NATIONS CONFERENCE ON TRADE AND DEVELOPMENT. Investment Policy Hub. Disponível em: <http://investmentpolicyhub.unctad.org/IIA>. Acesso em: 26 out 2015.
} 
parte invista na outra ${ }^{57}$. Ademais, ainda segundo Vandevelde, a complexidade de relações e as disciplinas que se deram no âmbito desses tratados durante a Era Global é tão grande que já impulsiona e embasa o surgimento de uma quarta era na história dos tratados bilaterais de investimento ${ }^{58}$, ainda sem denominação.

Logo, no contexto de aprofundamento da Era Global, e com a eclosão de uma quarta fase, o que se observa é um efetivo movimento de internacionalização ${ }^{59}$ e o aparecimento de novos Estados como potenciais investidores, em especial, países considerados emergentes, que ao tomarem gradativamente essa posição, trazem à tona a questão legítima da necessidade de proteção jurídica internacional de seus investidores.

\subsubsection{Principais Cláusulas}

Os tratados bilaterais de investimento possuem previsões bastante parecidas, cada qual podendo implicar em consequências práticas nos ordenamentos jurídicos dos Estados envolvidos ${ }^{60}$. Apesar de não existir um padrão único, é possível identificar nesses instrumentos, principalmente, as seguintes matérias: (i) definições de investimento e investidor; (ii) escopo de aplicação; (iii) admissão e estabelecimento; (iv) tratamento (o que engloba, segundo Sornarajah, tratamento nacional, tratamento da nação mais favorecida e tratamento justo e equitativo); (v) expropriação; (vi) compensação; (vii) transferência de fundos e (viii) resolução de conflitos (entre Estados e entre investidor e Estado $)^{61}$.

\subsubsection{Definições}

${ }^{57}$ ELKINS, Zachary; GUZMAN, Andrew T.; SIMMONS, Beth. Competing for Capital: The Diffusion of Bilateral Investment Treaties, 1960-2000. University of Illinois Law Review, Illinois, n. 265, p.265-304, 2008. p. 274. Disponível em: <http://scholarship.law.berkeley.edu/facpubs/433>. Acesso em: 30 jun. 2014.

${ }^{58}$ VANDEVELDE, Kenneth J. A brief history of international investment agreements, U.C. Davis Journal of International Law \& Policy, v. 12, n. 1, p.157-194, 2005.

${ }^{59}$ FLEURY, Afonso, FLEURY, Maria Tereza Leme. Multinacionais brasileiras: competências para a internacionalização Rio de Janeiro: FGV, 2012. p. 149.

${ }^{60}$ XAVIER JÚNIOR, Ely Caetano. Direito internacional dos investimentos e o Brasil: uma perspectiva a partir do padrão de tratamento justo e equitativo. 2014. 279 f. Dissertação (Mestrado em Direito) Faculdade de Direito da Universidade Estadual do Rio de Janeiro, Rio de Janeiro, 2014. f. 189.

${ }^{61}$ SORNARAJAH, M. The international law on foreign investment. 2nd. New York: Cambridge University Press, 2004. p. 207-217. BISHOP, R. Doak, CRAWFORD, James, REISMAN, W. Michael. Foreign investment disputes: cases, materials and commentary. The Hague: Kluwer Law International, 2005. p. 10 . 
Após o preâmbulo, seção clausular que objetiva expor a motivação política e econômica dos acordos, a previsão que se segue diz respeito às definições. Todos os tratados procuram definir alguns dos termos que são utilizados em seu bojo, para que se melhor compreenda os direitos a serem tutelados e os deveres do Estado receptor em respeitá-los. Dentre as definições mais comuns nos tratados, ressalta-se a de investimentos, disposição que se torna crucial, ao passo que esclarece a cobertura de proteção do acordo.

De acordo com Peter Muchlinski, a maioria dos acordos tende a tipificar este conceito de forma ampla, incluindo definições que não abrangem apenas o capital circulante ou ativos físicos, mas também direitos de propriedade intelectual e concessões contratuais ${ }^{62}$. Nesse contexto, as partes optam por direcionar o que consideram investimentos de distintas maneiras. Segundo a United Nations Conference on Trade and Development (UNCTAD), pode-se distinguir as definições de investimentos em quatro classificações: (i) de forma ampla, baseada em ativos, englobando qualquer tipo de bem ou direito controlados pelo investidor; (ii) através de uma abordagem tautológica, que foca nas características do investimento ao invés de conceituá-lo; (iii) por meio de uma lista fechada (closed-list definition) do que pode ser considerado investimento e (iv) por intermédio de uma lista restritiva ou fechada, que exclui certos ativos e transações da definição de investimentos ${ }^{63}$.

Outra definição relevante é a de investidor, que abarca pessoas físicas com a nacionalidade de uma das Partes Contratantes, em afirmação ao critério da nacionalidade, e, usualmente, residentes permanentes no território de uma das Partes Contratantes, de acordo com o direito doméstico do Estado. A questão da dupla nacionalidade por vezes também é trabalhada, aduzindo-se que o indivíduo deve ser considerado nacional do país que tem a nacionalidade dominante e efetiva. Além das pessoas naturais, também são incluídas pessoas jurídicas, em que normalmente a definição de investidor é mais complexa e pode ser respaldada em diversos critérios (que podem ser utilizados de forma isolada ou em conjunto), como o local de incorporação da empresa, o local de registro de sua sede ou a sede da companhia ou pela nacionalidade dos controladores da empresa.

\footnotetext{
${ }^{62}$ MUCHLINKSKI, Peter T. Multinational enterprises \& the law. 2nd. Oxford: Oxford University Press, 2007, p. 676.

${ }^{63}$ UNITED NATIONS CONFERENCE ON TRADE AND DEVELOPMENT. Bilateral Investment Treaties 1995-2006: Trends in Investment Rulemaking New York; Geneva: United Nations, 2007. p. 7. Disponível em: <http://unctad.org/en/docs/iteiia20065_en.pdf>. Acesso em: 30 jun. 2014.
} 
Nesse sentido, não se pode olvidar do caso Barcelona Traction $^{64}$, que aborda justamente a questão da nacionalidade da empresa investidora. Neste caso, foi discutida a noção de controle sobre o investimento, em que uma companhia instalada na Espanha e que promovia serviços de eletricidade, teve sua falência declarada em razão de medidas restritivas à sua atividade pelo governo espanhol. A empresa possuía controle acionário majoritariamente belga, porém, sua constituição foi realizada no Canadá, tendo a companhia fixado sua sede estatutária e sede social neste país. Após malogradas tentativas de demandar o Estado espanhol diante do judiciário nacional, os acionistas decidiram recorrer ao governo da Bélgica para que este acionasse a Espanha perante a Corte Internacional de Justiça (CIJ), em exercício da proteção diplomática exercida frente seus nacionais. A CIJ, por sua vez, decidiu que a Bélgica não possuía legitimidade ativa para demandar o Governo espanhol e pleitear indenização, pois se tratava de sociedade canadense, sendo irrelevante que o controle acionário fosse belga. Considerou-se, portanto, o critério da nacionalidade da pessoa jurídica pelo país de sua constituição (critério social). Assim sendo, essa discussão ensejou a incorporação da noção de controle nas definições de investimento e investidor presentes nos APPRIs.

Além das definições de investimento e investidor, comuns a todos os TBIs, existem também outras definições específicas concernentes às previsões contidas em cada TBI, que em razão de sua particularidade não serão aqui pormenorizadas, contudo, pode-se citar algumas das demais definições a título ilustrativo, como é o caso das definições de território, moeda livremente conversível, renda, dentre outras.

\subsubsection{Admissão e Estabelecimento}

Conforme pontua Peter Muchlinski, os Estados são plenamente capazes e aptos a instituir restrições legislativas à entrada de investimentos estrangeiros em seu território ${ }^{65}$. Esta situação se torna relevante ao passo que causa impacto político sobre o Estado receptor, principalmente em setores como de exploração de recursos naturais e na oferta de

${ }^{64}$ INTERNATIONAL COURT OF JUSTICE. Case concerning the Barcelona Traction, Light and Power Company Limited (Belgium v. Spain). Judgement, 5 fev.1970. ICJ Reports, 1970. p. 3. Disponível em: $<$ http://www.icj-cij.org/docket/files/50/5387 pdf >. Acesso em: 30 out. 2015.

${ }^{65}$ MUCHLINKSKI, Peter T. Multinational enterprises \& the law. 2nd. Oxford: Oxford University Press, 2007. p. 677. 
serviços públicos ${ }^{66}$. Nesse contexto, pode-se afirmar que o direito de entrada não é direito absoluto do investidor, haja vista que o direito interno tem o condão de reservar alguns setores da economia apenas aos investidores domésticos, seja devido ao intuito de se fomentar o desenvolvimento nacional, seja por questões de segurança nacional.

Desse modo, o Direito Internacional dos Investimentos reagiu a esse fato estabelecendo as denominadas cláusulas de admissão, as quais são frequentemente associadas à promoção ou ao encorajamento do investimento ${ }^{67}$, determinando basicamente o direito de presença para que os investimentos estrangeiros possam se instalar no Estado receptor, através da indicação da legislação do Estado receptor como apta. Ademais, podem haver também previsões estipuladas no próprio tratado, em que setores cobertos serão especificados em listas positivas ou negativas ${ }^{68}$, o que configura o modelo de direito de estabelecimento.

Nesse âmbito, há também de ser analisado o modo de tratamento do investimento no momento de estabelecimento no território do país receptor, o qual, associado aos conceitos de tratamento nacional e nação mais favorecida, não deve ser menos favorável que o conferido aos investidores nacionais ou a investidores de terceiros Estados. Nesse sentido, vislumbram-se duas formas de abordagem nos acordos de investimentos, o primeiro deles, prevê que a cláusula de estabelecimento disponha sobre uma entrada controlada, que reserva o direito ao Estado receptor de regular o ingresso de investimentos em âmbito nacional.

O segundo trata-se de um acordo em que há total liberalização, pelo que se estende o padrão de não discriminação presente no acordo também à fase de préestabelecimento do investimento, ou seja, aplica-se aos investimentos já existentes anteriormente à entrada em vigor do tratado. Esta prática é comum no modelo de TBI americano, que cria direitos anteriores à entrada dos investimentos e pode acarretar em consequências na ordem de ampliar a proteção a todos os estágios do investimento ${ }^{69}$.

\footnotetext{
${ }^{66}$ COSTA, José Augusto Fontoura. Direito Internacional do Investimento Estrangeiro. Curitiba: Juruá, 2010. p. 136.

${ }^{67}$ PERRONE-MOISÉS, Claudia. Direito ao desenvolvimento e investimentos estrangeiros. São Paulo: Editora Oliveira Mendes, 1998. p. 30.

${ }^{68}$ COSTA, José Augusto Fontoura. Direito Internacional do Investimento Estrangeiro. Curitiba: Juruá, 2010. p. 136.

69 JOUBIN-BRET, Anna. Admission and establishment in the context of investment protection In: REINISCH, August (Org.). Standards of investment protection. Oxford: Oxford University Press, 2008. p. 13.
} 
Contudo, ressalta-se que ainda são poucos os TBIs que criam direitos anteriores à entrada de investimentos ${ }^{70}$.

\subsubsection{Tratamento}

Os acordos de investimento contêm obrigações referentes ao tratamento conferido aos investimentos uma vez que estes foram estabelecidos. Esses tratamentos podem ser gerais, os quais se referem a todos os aspectos de existência dos investimentos no Estado receptor, subdividindo-se em padrões de tratamento: (i) absolutos, aqueles que estabelecem o tratamento a ser concedido ao investimento, sem referir-se à maneira pela qual outros investimentos são tratados, como é o caso do tratamento justo e equitativo; (ii) ou relativos, em que o tratamento exigido é definido em função do tratamento concedido a outros investimentos, como é o caso do tratamento nacional e do tratamento da nação mais favorecida, que são as normas relativas por excelência.

Os acordos de investimentos normalmente conferem atenção ao princípio do tratamento justo e equitativo, apesar de este conceito ainda possuir alto grau de abstração, sem haver consenso unívoco sobre sua definição, nem tampouco esta ser explanada nos APPRIs. Pode ser utilizado isoladamente ou em combinação com outros padrões de tratamento, como proteção e segurança integrais e não discriminação, pelo que isto deve ser explícito no texto do acordo ${ }^{71}$. Nesse sentido, o tratamento justo e equitativo pode ser interpretado de acordo com algumas tendências.

A primeira delas abre espaço para que o tratamento justo e equitativo seja compreendido como uma referência aos padrões mínimos de tratamento (international minimum standard of treatment of aliens), representando uma garantia advinda do Direito Internacional costumeiro para que não haja violação ao tratamento isonômico conferido aos estrangeiros, sendo que o Estado receptor de investimentos deve agir sob a égide da boa-fé, sem arbitrariedades ou ambiguidades e de modo transparente ${ }^{72}$. A segunda corrente

${ }^{70}$ COSTA, José Augusto Fontoura. op. cit., p. 138.

71 UNITED NATIONS CONFERENCE ON TRADE AND DEVELOPMENT. Bilateral Investment Treaties 1995-2006: Trends in Investment Rulemaking. New York and Geneva: United Nations, 2007, p.28. Disponível em: $<$ http://unctad.org/en/docs/iteiia20065_en.pdf $>$. Acesso em: 30 jun. 2014.

${ }^{72}$ MUCHLINKSKI, Peter T. Multinational enterprises \& the law. 2nd. Oxford: Oxford University Press, 2007. p. 682-683. KINGSBURY, Benedict; SCHILL, Stephan. Investor-State Arbitration as Governance: Fair and Equitable Treatment, Proportionality and the Emerging Global Administrative Law. New York University School of Law Public Law \& Legal Theory Research Paper Series Working Paper, No 09-46. 
de interpretação reside no fato de alguns APPRIs vincularem o padrão justo e equitativo em conformidade ao Direito Internacional, limitando a margem de interpretação dos tribunais arbitrais aos parâmetros adstritos às fontes do Direito Internacional. Importante destacar que alguns APPRIs fazem referência ao tratamento justo e equitativo à medida em que encontram-se presentes determinados elementos concretos que devem ser expressamente previstos nos tratados, bem como respeitados durante atuação do Estado receptor, como por exemplo, a proibição de denegação de justiça, a proibição de medidas discriminatórias e a impossibilidade de alegar violação ao tratamento justo e equitativo em decorrência de violação de outro dispositivo do tratado ou de outra obrigação internacional ${ }^{73}$.

Ressalta-se que em decisões provenientes de arbitragens investidor-Estado, em que há a previsão de tratamento justo e equitativo de forma autônoma e literal, criou-se uma noção do que seria uma conduta violadora desta disposição, tendo-se chegado a cinco elementos: (i) arbitrariedade nas tomadas de decisão; (ii) negação do acesso à justiça; (iii) discriminação; (iv) tratamento abusivo e coerção aos investidores e (v) adoção de medidas que contrariam as expectativas legítimas dos investidores ${ }^{74}$.

Desta forma, apesar deste padrão de tratamento ser amplo e sua interpretação ser bastante variada, trata-se de disposição frequente nos TBIs, uma vez que inclui também o papel a boa-fé no tratamento conferido aos investidores no território do Estado receptor.

Nessa esteira, outro padrão de tratamento estipulado frequentemente nos TBIs diz respeito ao tratamento nacional. Este consiste na obrigação de tratar o investidor de modo não menos favorável que o investidor nacional. Observa-se que, tanto o tratamento nacional, quanto o tratamento da nação mais favorecida possuem redação padrão, em que se define primeiramente o escopo de aplicação, ou seja, se se permite a aplicação na fase pré e pós-estabelecimento ou apenas no pós-estabelecimento.

2009. Disponível em: $<$ http://papers.ssrn.com/sol3/papers.cfm?abstract_id=1466980>. Acesso em: 1 nov. 2015.

${ }^{73}$ XAVIER JÚNIOR, Ely Caetano. Direito internacional dos investimentos e o Brasil: uma perspectiva a partir do padrão de tratamento justo e equitativo. 2014. 279 f. Dissertação (Mestrado em Direito) Faculdade de Direito da Universidade Estadual do Rio de Janeiro, Rio de Janeiro, 2014. f. 196.

${ }^{74}$ PANZINI, Fabrizio; NEGRI, Constanza. O retorno dos acordos de investimentos na agenda comercial brasileira. Revista Brasileira de Comércio Exterior, Rio de Janeiro, ano 29, n. 123, abr./jun. p. 58-72, 2015. p. 63. 
Podem ser estipuladas situações em que estas serão aplicadas, como se a algum setor específico ${ }^{75}$, e, posteriormente, será estabelecido o parâmetro de tratamento, qual seja o tratamento não menos favorável que o conferido ao nacional. Ademais, o tratamento nacional também pode ser relacionado com os outros padrões de tratamento instituídos, como o tratamento justo e equitativo e o de nação mais favorecida.

O tratamento nacional configura-se como padrão relativo, como já exposto anteriormente, o que significa que se faz comparação em relação ao tratamento conferido pelo Estado a seus investidores nacionais e o tratamento presente no tratado em apreço. Destaca-se que, no entendimento de José Augusto Fontoura Costa (2010, p. 142):

O tratamento nacional, da mesma maneira que o de NMF, admite a discriminação de direito e a de fato. Sua análise depende, portanto, da comparação entre os regimes jurídicos de investidores nacionais e estrangeiros, para a caracterização ou não de discriminação de jure, bem como a análise do tratamento efetivo recebido pelos investidores em circunstâncias similares para a configuração da discriminação de facto. Em qualquer das hipóteses, cumpre ressaltar, [que] o tratamento "não precisa, necessariamente, ser idêntico", o que, para a discriminação de jure significa seguir o mesmo regime jurídico. O que se exige, porém, é que não seja "menos favorável ${ }^{76}$.

Assim sendo, a aplicação do tratamento nacional pressupõe necessariamente uma análise comparativa entre o tratamento conferido pelo Estado receptor aos investimentos ou investidores domésticos e ao tratamento garantido pelo mesmo país aos investimentos ou investidores estrangeiros da outra Parte Contratante do acordo. Logo, esse cotejo não visa a alcançar a resposta se o tratamento é idêntico, mas sim, se ele é menos favorável ${ }^{77}$.

Por fim, outro standard de tratamento relevante previsto nos acordos de investimento é o do tratamento da nação mais favorecida. Este estipula que uma Parte Contratante não pode conferir tratamento a investimento ou investidor da outra Parte, que seja menos favorável que aquele concedido a investimento ou investidor em acordos firmados com terceiros países. Caso esta situação ocorra, o tratamento mais benéfico disfrutado pelo terceiro deve ser estendido à Parte Contratante.

Essa outra variável do princípio da não discriminação também se trata de padrão de tratamento relativo, ou seja, faz-se necessário que haja o cotejo com a forma de tratamento exercida pelo Estado receptor em outro acordo com Estados terceiros. Ainda,

75 UNITED NATIONS CONFERENCE ON TRADE AND DEVELOPMENT. National Treatment: UNCTAD Series on issues in international investment agreements. New York; Geneva, 1999. p. 11.

${ }^{76}$ COSTA, José Augusto Fontoura. Direito Internacional do Investimento Estrangeiro. Curitiba: Juruá, 2010. p. 142.

77 UNITED NATIONS CONFERENCE ON TRADE AND DEVELOPMENT. Bilateral Investment Treaties 1995-2006: Trends in Investment Rulemaking. New York; Geneva: United Nations, 2007. p. 36. 
segundo a UNCTAD, este padrão de tratamento é tido como um dos principais instrumentos utilizados por países em desenvolvimento para que possam se beneficiar de um maior poder de barganha com terceiros países. Por fim, atualmente, estipula-se algumas exceções a esse princípio, como no que se refere à tributação e aos acordos que estabelecem organizações econômicas de integração regional que os Estados Contratantes fazem parte $^{78}$.

$\mathrm{Na}$ jurisprudência arbitral, verifica-se que o tratamento da nação mais favorecida não se aplica apenas às previsões materiais, existindo hipóteses de extensão procedimental à cláusula de solução de controvérsias. No caso Emilio Augustin Maffezini v. The Kingdom of $\operatorname{Spain}^{79}$, o senhor Maffezzini, nacional e investidor argentino, sentindo-se prejudicado, promoveu demanda contra a Espanha com respaldo na cláusula da nação mais favorecida prevista no TBI entre Argentina e Espanha. O demandante invocou obrigação contida no TBI entre Chile e Espanha, para que pudesse se utilizar do benefício da cláusula de solução de controvérsias contida neste acordo de forma imediata, a qual não exigia esgotamento de recursos internos antes de se recorrer à arbitragem. Logo, isso permitiria o acesso a esse mecanismo sem ter de esgotar previamente as instâncias judiciárias espanholas. O laudo arbitral foi de que o tribunal se declarava competente sobre a disputa, haja vista que existiam outros acordos mais favoráveis ao investidor que o tratado-base ao estipular o acesso direto ao mecanismo arbitral. Dessa forma, em consonância com a nação mais favorecida, este seria aplicado ao caso em tela ${ }^{80}$.

Desse modo, apesar de não ser unívoco o preceito de extensão da nação mais favorecida à cláusula de solução de controvérsias, é inegável que esta decisão abriu margem para esta prática. Assim, alguns investidores conseguem se beneficiar de disposições sobre resolução de disputas previstas em outros APPRIs firmadas entre o Estado receptor de investimentos e países terceiros para poderem iniciar procedimentos arbitrais contra o Estado hospedeiro. Nesse contexto, de forma a neutralizar este precedente, hoje em dia se verifica cláusulas nos acordos de investimento aduzindo que

\footnotetext{
${ }^{78}$ UNITED NATIONS CONFERENCE ON TRADE AND DEVELOPMENT. Ibid. p 38-43.

${ }^{79}$ INTERNATIONAL CENTRE FOR SETTLEMENT OF INVESTMENT DISPUTES. Emilio Augustin Maffezini v. The Kingdom of Spain, ICSID Case n.ARB/97/7, Award, 13 Nov., 2000.

${ }^{80}$ CARREAU, Dominique; JUILLARD, Patrick. Droit international économique. 5ed. Paris: Dalloz, 2013. p. 523. Outros casos que também consideraram juridicamente aceitável importar a cláusula de resolução de conflitos através da nação mais favorecida foram: Suez v. Argentina (2006), Gas Natural v. Argentina (2005), Suez e Vivendi v. Argentina (2006), todos sob os auspícios do CIRDI, e RosInvest v. Russia (2010), sob a jurisdição da Câmara de Comércio de Estocolmo.
} 
não é possível a extensão da nação mais favorecida nesta situação de não estipulação, no escopo do tratado, da arbitragem investidor-Estado como mecanismo de solução de controvérsias.

\subsubsection{Expropriação}

Desde a criação das primeiras previsões de proteção aos investimentos estrangeiros, por meio do direito costumeiro, as expropriações possuem destaque no que concerne à proteção da propriedade do investidor em território estrangeiro. Quanto à licitude das expropriações, ressalta-se que o direito de expropriação é legítimo, contanto que esta não seja arbitrária, seja consoante o interesse público, não seja discriminatória e seja devidamente compensada.

É comum a existência de disposições nos TBIs definindo expropriação, contudo, esta não mais se resume somente à expropriação direta, isto é, quando se trata da transferência da propriedade de ativos - bastante comum nas áreas de exploração de recursos minerais ou na concessão de serviços. Atualmente, existem previsões nos acordos de investimentos, principalmente nos TBIs americanos, sobre expropriação indireta. Nesta situação, instrumentos regulatórios estatais implicam na redução significativa do valor do investimento, acarretando prejuízos econômicos graves para o investidor. Estas últimas medidas tornam-se tão prejudiciais ao investidor estrangeiro que fazem com que a manutenção da propriedade ou o exercício da atividade restem-se onerosos a ponto de não haver alternativa senão vender o empreendimento mesmo a preço inferior.

Entretanto, existem dificuldades para se circunscrever os limites dessa expropriação regulatória e como essa ação estatal passa a ser expropriatória, visto que esta noção ainda é bastante imprecisa e as jurisprudências nacionais não são convergentes a respeito, o que não contribui para seu esclarecimento. Ademais, uma alternativa que se tem aventado é a previsão nos TBIs do caráter excepcional das expropriações indiretas, como no caso do TBI entre EUA e Uruguai ${ }^{81}$.

${ }^{81}$ Segundo Anexo B, do TBI entre EUA-Uruguai: "The determination of whether an action or series of actions by a Party, in a specific fact situation, constitutes an indirect expropriation, requires a case-bycase, fact-based inquiry that considers, among other factors: (i) the economic impact of the government action, although the fact that an action or series of actions by a Party has an adverse effect on the economic value of an investment, standing alone, does not establish that an indirect expropriation has occurred; (ii) the extent to which the government action interferes with distinct, reasonable investment- 
As principais críticas à expropriação indireta residem no fato de que esta pode implicar na redução do regulatory chilling ou espaço regulatório dos Estados na implementação de suas políticas, contudo, apesar disso, verifica-se na prática os dois lados da moeda, seja a restrição da amplitude regulatória do Estado através desta cláusula, seja a adoção de medidas protecionistas, desenvolvidas sob a justificativa de atenderem ao interesse público ${ }^{82}$.

\subsubsection{Compensação}

As disposições sobre compensação no que tange à expropriação foram amplamente discutidas desde o início do século XX, quando da criação da fórmula Hull. Após as Revoluções Mexicana, de 1910, e Russa, de 1917, diversas expropriações foram realizadas sem compensação, o que causou revolta dos investidores estrangeiros à época. Nesse sentido, algumas iniciativas foram tomadas. Em 1938, o Secretário de Estado dos EUA instituiu a denominada Fórmula Hull, expressando a visão americana de direitos e obrigações dos Estados receptores para com os investidores. Foi estabelecido padrão de tratamento que fora adotado internacionalmente a posteriori, em que as compensações deveriam ser prontas, adequadas e efetivas. Prontas, haja vista que deveriam se dar sem atrasos indevidos; adequadas, pois deveria haver o ressarcimento integral do valor dos ativos expropriados, considerando o valor de mercado do investimento no momento de expropriação e efetiva, pelo que deve ser realizada em moeda livremente conversível.

Atualmente há um elevado grau de convergência entre os APPRIs quanto ao padrão de compensação, que deve seguir o valor de justo mercado ou o valor genuíno dos ativos adquiridos. Há cláusulas sobre compensação que abrangem também o valor da compensação, a moeda em que esta deverá ser paga e o período para pagamento,

backed expectations; and (iii) the character of the government action". UNITED STATES OF AMERICA. Treaty Between the United States of America and the Oriental Republic of Uruguay Concerning the Encouragement and Reciprocal Protection of Investment. Disponível em: $<$ https://ustr.gov/sites/default/files/uploads/agreements/bit/asset_upload_file748_9005.pdf $>$. Acesso em: 7 nov. 2015.

${ }^{82}$ PANZINI, Fabrizio; NEGRI, Constanza. O retorno dos acordos de investimentos na agenda comercial brasileira. Revista Brasileira de Comércio Exterior, Rio de Janeiro, ano 29, n. 123, p. 58-72, abr.-jun., 2015. p. 63. 
entretanto, segundo a UNCTAD, há o questionamento se essas cláusulas deverão prever ou não juros e qual o critério para determiná- $\operatorname{los}^{83}$.

\subsubsection{Transferência de Fundos}

A transferência de fundos é disposição particularmente importante para os investidores estrangeiros, haja vista que ao se implementar um investimento em território estrangeiro espera-se que posteriormente seja efetuada a transferência de lucros, capitais e outros pagamentos como condições primordiais para a operacionalização destes investimentos. Assim, torna-se primordial ao investidor estrangeiro poder dispor livremente do capital empregado, com a possibilidade de reinvesti-lo em atividades locais, de remissão dos lucros ou repatriação de capitais empregados.

$\mathrm{O}$ entrave reside no fato de muitos Estados restringirem esse fluxo com vistas à implementação de políticas desenvolvimentistas e de controle cambial, por isso a necessidade de os TBIs regularem tal matéria, para que não haja imprevistos, restrições e prejuízos ao investidor, mas sim proteção aos ativos financeiros deste. Por isso, alguns TBIs especificam quais ativos e operações são cobertas pelo acordo através de rol exemplificativo ou taxativo.

O principal temor dos países receptores de investimentos reside na ocorrência de graves desequilíbrios em sua balança de pagamentos, e na interferência, em função da proteção conferida pelo APPRI, do poder do Estado em limitar essas transferências de capital, baseadas na repatriação de capital ou remessa de lucros, e na criação de medidas de proteção cambial necessárias a conter a evasão de divisas nacionais ${ }^{84}$.

\subsubsection{Resolução de Conflitos}

Da perspectiva do investidor, a principal vantagem da instauração de um mecanismo de solução de disputas reside na garantia de que as obrigações do acordo de investimentos serão efetivamente implementadas e cumpridas. Segundo a UNCTAD, isso

${ }^{83}$ UNITED NATIONS CONFERENCE ON TRADE AND DEVELOPMENT. Bilateral Investment Treaties 1995-2006: Trends in Investment Rulemaking. New York; Geneva: United Nations, 2007. p. 48-49. Disponível em: <http://unctad.org/en/docs/iteiia20065_en.pdf $>$. Acesso em: 30 jun. 2014.

${ }^{84}$ COSTA, José Augusto Fontoura. Direito Internacional do Investimento Estrangeiro. Curitiba: Juruá, 2010. p.142. 
aumenta o nível de certeza e previsibilidade que os investidores necessitam, sendo um dos elementos-chave para diminuir o risco enfrentado e encorajar os investidores de uma Parte Contratante a investir no território da outra ${ }^{85}$. Ademais, a proliferação do mecanismo de solução de controvérsias demonstra-se como um marco importante na transição do sistema power oriented, em que as disputas eram resolvidas por meios políticos e pela força, para um sistema rule oriented, respaldado no direito e nos mecanismos adjudicatórios.

Dentre as disposições padrão para dirimir conflitos encontra-se a arbitragem entre Estados e a arbitragem investidor-Estado. Esclarece-se que a primeira não é tão frequente, haja vista não possibilitar o acesso direto do investidor ao mecanismo, tendo de passar pelo crivo discricionário de seu Estado de origem, para que este possa acionar a outra Parte. Essa sistemática se assemelha à proteção diplomática, que foi utilizada mais frequentemente até a Segunda Guerra Mundial.

Noutro giro, a previsão da arbitragem investidor-Estado, que possibilita o acesso direto do investidor, tem sido reconhecida como modo mais imediato e efetivo para se discutir as controvérsias aventadas. Dentre os argumentos em favor da arbitragem mista investidor-Estado, encontram-se o receio da falta de imparcialidade dos organismos jurisdicionais estatais, a ausência de regras aplicáveis adequadas e de julgadores especializados e a morosidade do sistema judiciário nacional.

Ademais, as disposições relativas a esse meio de solução de controvérsias se apresentam como um dos principais instrumentos dos TBIs, abrangendo em sua configuração principalmente fases prévias de negociação e conciliação; escolha do sistema adjudicatório pelo reclamante (disposição fork-in-the-road); indicação da instituição arbitral e de suas regras; e possibilidade de o Estado ser autor ${ }^{86}$. Ressalta-se que quase todos os acordos estipulam fases prévias de negociação obrigatórias, as quais devem ser realizadas em um período mínimo estabelecido (cooling-off period) e, findado este prazo, caso não se alcance acordo amigável, as partes podem acionar o mecanismo jurisdicional

85 UNITED NATIONS CONFERENCE ON TRADE AND DEVELOPMENT. Bilateral Investment Treaties 1995-2006: Trends in Investment Rulemaking. New York and Geneva: United Nations, 2007, p. 48-99.

${ }^{86}$ COSTA, José Augusto Fontoura. Direito Internacional do Investimento Estrangeiro. Curitiba: Juruá, 2010. p.162. 
que escolherem (se houver esta opção, na denominada cláusula fork-in-the-road) e, uma vez escolhido, este procedimento será definitivo ${ }^{87}$.

Nesse sentido, ressalta-se que o procedimento arbitral investidor-Estado será melhor analisado no capítulo 4. Contudo, desde já pode-se afirmar que se trata de recurso frequentemente utilizado pelos investidores estrangeiros, principalmente sob a égide do Centro Internacional para Resolução de Disputas sobre Investimentos (CIRDI) e de suas regras de arbitragem.

\subsection{O BRASIL E O REGIME JURÍDICO DA PROTEÇÃO DOS INVESTIMENTOS ESTRANGEIROS}

O Brasil tem uma trajetória profícua na atração de investimentos estrangeiros diretos. Durante a década de 1990 o país consolidou-se como destino extremamente atrativo, principalmente, de capitais provenientes de países desenvolvidos. Nos anos 2000, esse processo avançou ainda mais, alcançando cifras bilionárias, mesmo diante da crise econômica global de 2008. Nesse ínterim, destaca-se que, mesmo sem a adoção de padrão de proteção internacional sobre a matéria, haja vista ser tradicionalmente resistente a este sistema $^{88}$, o Estado brasileiro manteve a qualidade de um dos líderes na recepção de investimentos estrangeiros, mantendo-se nesta posição até hoje ${ }^{89}$.

Entretanto, o Brasil passa atualmente por um período de gradual transição de seu perfil econômico internacional, de apenas receptor de investimentos para também investidor. Isso suscitou uma mudança de posição do governo brasileiro em direção à aderência aos acordos de promoção e proteção de investimentos, para que se possa salvaguardar os interesses das transnacionais brasileiras no exterior.

Desse modo, a presente seção tem por escopo descrever o perfil do Brasil como grande receptor de investimentos, através da análise de dados estatísticos, bem como

\footnotetext{
${ }^{87}$ Segundo José Augusto Fontoura Costa: "Há, no entanto, muitos acordos em que a exigência parcial de esgotamento dos recursos internos é feita, indicando-se um prazo em que, continuando pendente a ação no Judiciário do Estado receptor, as partes podem recorrer à arbitragem internacional”.Ibid., p.163.

${ }^{88}$ MAGALHÃES, José Carlos de. Acordos Bilaterais de Promoção e Proteção de investimentos. Revista de Informação Legislativa, n.134, ano 34, Brasília, p. 13-18, abr-/jun., 1997. Disponível em: $<$ http://www2.senado.leg.br/bdsf/bitstream/handle/id/248/r135-02.pdf?sequence=4>. Acesso em: 2 jul. 2014.

${ }^{89}$ VEIGA, Pedro da Motta; RIOS, Sandra Polónia. Os investimentos brasileiros no exterior: características, motivações e agenda de políticas. Revista Brasileira de Comércio Exterior, ano 28, n.118, p.2-35, jan./mar. 2014. p.4-19.
} 
apresentar o histórico particular brasileiro na regulação internacional dos investimentos, trazendo à baila os TBIs assinados na década de 1990, porém não ratificados, e qual foi a motivação para tanto. Será examinada também a regulação dos investimentos estrangeiros no Direito Brasileiro, e, por fim, será analisada a transição do país de mero receptor de investimentos à condição de emissor de investimentos estrangeiros, por intermédio dos dados mais recentes quanto à expansão das empresas brasileiras e como o investimento brasileiro no exterior tem sido tratado.

\subsubsection{Brasil e o Fluxo de Investimentos Estrangeiros Diretos}

Historicamente, o Brasil é reconhecido como um dos maiores receptores de investimento externo direto do mundo. Advindos principalmente de países desenvolvidos, registra-se que nosso país passou por dois ciclos de forte expansão dos investimentos estrangeiros diretos. O primeiro teve início em 1995, após ter permanecido afastado por cerca de quinze anos do foco dos investimentos, em função da deterioração econômica do país $^{90}$. Importante destacar que com a grande abertura comercial vislumbrada pelo Brasil nos anos 1990, marcada também pela onda de privatizações de empresas industriais e de serviços pela retomada dos investimentos em setores industriais em que a presença estrangeira é forte, todos estes fatores contribuíram para a dinâmica desse ciclo ${ }^{91}$. Segundo a Confederação Nacional da Indústria (CNI), os fluxos de IED entre 1990 e 2000 passaram de US\$ 208 bilhões para US\$1,4 trilhão ${ }^{92}$.

Outrossim, o que se percebe nos anos 2000 é um longo período marcado por oscilações. Avançando-se nesse contexto, o segundo ciclo de expansão teve início em 2004, estabilizando-se, contudo, em níveis mais elevados somente a partir de 2006. Apesar da queda ocorrida em 2009, salienta-se que esta foi superada de forma rápida, tendo o ciclo de expansão se estendido até $2011^{93}$. O que se verifica nos últimos anos é uma queda nos fluxos de investimento externo diretos para o Brasil, porém, mesmo assim, os valores contabilizados em 2012, 2013 e 2014 ainda se mantiveram acima de US\$ 60 bilhões anuais - nível atingido apenas em 2011 - conforme se observa no gráfico a seguir:

\footnotetext{
${ }^{90}$ CONFEDERAÇÃO NACIONAL DA INDÚSTRIA. Investimentos estrangeiros diretos no Brasil 2014 os regimes e políticas de IED: tendências recentes no mundo e no Brasil. Brasília: CNI, 2015, p. 27.

${ }^{91}$ Ibid., p. 27.

92 Ibid., p. 5.

${ }^{93}$ Ibid., p. 5-7.
} 
Gráfico 1 - Entrada de Investimento Estrangeiro Direto no Brasil (2007-2014)

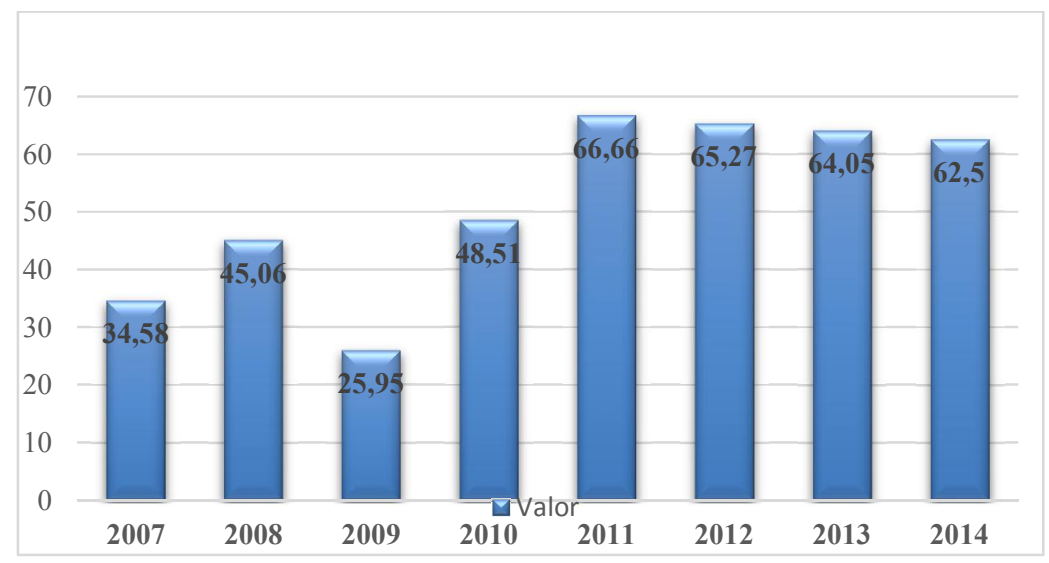

Fonte: Confederação Nacional da Indústria (CNI), $2015^{94}$.

Em 2014, os investimentos estrangeiros diretos ingressantes no Brasil somaram US\$ 62,5 bilhões, havendo uma queda comparada ao ano de 2013, quando estes atingiram o patamar de US\$ 64,05 bilhões ${ }^{95}$. Ocorre que esta queda não foi suficiente para desbancar o Brasil como um dos principais países receptores de investimentos do mundo, tendo passado da sétima posição em 2013, para a sexta em 2014 - ficando atrás apenas de China, Hong Kong, Estados Unidos, Reino Unido e Cingapura) e permanecendo como o líder na canalização de investimentos na América Latina ${ }^{96}$.

Ressalta-se que a existência de um grande mercado interno foi elemento fundamental para a entrada de capital nos últimos anos. Além disso a isonomia de tratamento conferida a investidores nacionais e estrangeiros, e a abertura para os setores de

${ }^{94}$ CONFEDERAÇÃO NACIONAL DA INDÚSTRIA. Investimentos estrangeiros diretos no Brasil 2014 os regimes e políticas de IED: tendências recentes no mundo e no Brasil. Brasília: CNI, 2015, p.16.

${ }^{95}$ Em 2014, as principais origens do investimento externo direto para o Brasil foram, respectivamente: 1) Países Baixos; 2) Estados Unidos; 3) Luxemburgo; 4) Espanha; 5) Japão; 6) França; 7) Suíça; 8) México; 9) Chile; 10) Reino Unido. Cf. Ibid., p. 35.

${ }^{96}$ UNITED NATIONS CONFERENCE ON TRADE AND DEVELOPMENT. World Investment Report 2015: reforming international investment governance. New York and Geneva: United Nations, 2015. p. 5 e p. 58. Ibid., p. 13. 
petróleo e gás, telecomunicações, eletricidade, portos e saúde também influenciaram para esta maior atração de investimentos ${ }^{97}$.

Entretanto, com a onda de adesões aos tratados de investimento pelos países da América Latina, haja vista que se proliferara na região a retórica de que esses instrumentos seriam a chave para a atração de investimentos, porquanto possibilitariam uma maior segurança jurídica ao particular, o Brasil permaneceu de fora desse sistema, colocando em dúvida se esta condição de atração de capitais realmente dependia dos acordos de investimento, mesmo porque a atração de vultosos fluxos de capital externo ao território brasileiro ocorria mesmo o país não possuindo qualquer instrumento internacional de proteção $^{98}$.

\subsubsection{O Tratado Bilateral de Investimentos Brasileiro na Década de 1990}

Apesar da resistência brasileira ao regime dos acordos internacionais de investimento desde sua gênese, destaca-se que na década de 1990 o país firmou catorze tratados bilaterais de investimento. Nesse sentido, passa-se à análise pormenorizada das previsões materiais e procedimentais dos TBIs brasileiros, bem como as motivações que levaram à sua não ratificação pelo Poder Legislativo nacional. O intuito é que se possa vislumbrar melhor a evolução do posicionamento brasileiro, e, ao longo do estudo, que se tenha subsídios para identificar suas diferenças e similaridades com o acordo atual.

\subsubsection{Características}

Alegro ma non tropo, de 1995 a 1999, no primeiro mandato do então Presidente Fernando Henrique Cardoso, o Estado brasileiro chegou a assinar catorze tratados de

\footnotetext{
${ }^{97}$ PANZINI, Fabrizio; NEGRI, Constanza. O retorno dos acordos de investimentos na agenda comercial brasileira. Revista Brasileira de Comércio Exterior, ano 29, p.58-72, abr./jun. 2015. p. 66.

${ }^{98}$ COSTA, José Augusto Fontoura. Proteção internacional do investimento estrangeiro no MERCOSUL. Florianópolis: GEDAI, 2012, p. 21. Destaca-se que o Brasil assinou dois acordos no âmbito do Mercosul sobre o tema investimentos. O primeiro é o Protocolo de Colônia, de 1993, que se refere à proteção dos investimentos intrazona, e o segundo o Protocolo de Buenos Aires, de 1994, que envolve a proteção dos investimentos advindos extrazona. Entretanto, nenhum deles foi ratificado. Observa-se também que o Brasil é parte do Acordo de Garantia de Investimentos com os EUA, promulgado pelo Decreto n57.943, acordo realizado na década de 1960, com o objetivo de proporcionar um mecanismo de garantia contra riscos políticos. Cf. NUSDEO, Ana Maria de Oliveira. A experiência do decreto n57.943 como acordo de garantia de investimentos entre Brasil-EUA In: AMARAL JÚNIOR, Alberto do; SANCHEZ, Michelle Ratton (Cood.) Regulamentação internacional dos investimentos: algumas lições para o Brasil. São Paulo: Aduaneiras, p.303-321, 2007. p. 303-321.
} 
investimentos ${ }^{99}$, pelo que apenas seis deles foram levados ao Congresso Nacional por mensagem do Presidente para ratificação, tendo sido retirados em 12 de dezembro de 2002, previamente à posse do novo presidente Luiz Inácio Lula da Silva ${ }^{100}$.

Nesse contexto, nenhum desses tratados entrou em vigor e, desde então, a discussão sobre o tema em âmbito nacional se enfraqueceu e assim perdurou por mais de duas décadas, com um Brasil de posicionamento formalmente reticente e cauteloso. Ressalta-se que há parte da doutrina internacionalista brasileira que defende a adesão do país aos tratados bilaterais de investimento (e também à Convenção de Washington). Entretanto, conforme pontua Ely Caetano Xavier Júnior (2014) é possível vislumbrar dois pontos de vista complementares de argumentos nesse sentido:

\begin{abstract}
Alguns autores defendem a adesão do país a esses instrumentos internacionais de maneira a proteger o investidor brasileiro no exterior e permitir que ele tenha acesso aos mecanismos de solução de controvérsias com os Estados hospedeiros, ao passo que outros autores analisam também a compatibilidade do atual regime internacional de investimentos estrangeiros com o Direito Brasileiro ${ }^{101}$.
\end{abstract}

$\mathrm{Na}$ esteira do primeiro pressuposto, os tratados proporcionariam acesso ao mecanismo de solução de controvérsias investidor-Estado, o que abriria espaço para a despolitização das disputas internacionais sobre investimentos. Nádia de Araújo e Lauro de Gama e Souza Júnior afirmaram à época que a tentativa de assinar os TBIs seguia uma tendência global de atração de investimentos estrangeiros produtivos, porquanto estes “oferecem garantias modeladas em nível internacional ao capital alienígena que deseje ingressar e permanecer no país" ${ }^{102}$. Nesse mesmo sentido, José Carlos de Magalhães (1997, p. 13-18) assinalou que:

${ }^{99}$ O Brasil possui TBIs com Portugal (1994), Chile (1994), Reino Unido (1994), Suíça (1994), Dinamarca (1995), Finlândia (1995), França (1995), Alemanha (1995), Itália (1995), Coreia do Sul (1995), Venezuela (1995), Cuba (1997), Holanda (1998) e Bélgica/Luxemburgo (1999).

${ }^{100}$ Ressalta-se que mesmo somente 6 acordos tendo sido encaminhados ao Congresso para ratificação, todos eles tiveram seu processo de ratificação prejudicados e marcados por resistências. Cf. SCANDIUCCI FILHO, José Gilberto. O Brasil e os Acordos Bilaterais de Investimento In: Regulamentação Internacional dos Investimentos: algumas lições para o Brasil. AMARAL JÚNIOR, Alberto do; SANCHEZ, Michelle Ratton. São Paulo: Aduaneiras, 2007. p. 271-272; 301.

${ }^{101}$ XAVIER JÚNIOR, Ely Caetano. Direito internacional dos investimentos e o Brasil: uma perspectiva a partir do padrão de tratamento justo e equitativo. 2014.279f. Dissertação (Mestrado em Direito) Faculdade de Direito da Universidade Estadual do Rio de Janeiro, Rio de Janeiro, 2014. p.180.

${ }^{102}$ ARAÚJO, Nadia de; SOUZA JÚNIOR, Lauro de Gama e. Os acordos bilaterais de investimento com a participação do brasil e o direito interno - análise das questões jurídicas. In: CASELLA, Paulo Borba; MERCADANTE, Araminta de Azevedo (Coord). Guerra comercial ou integração mundial pelo comércio?: a omc e o brasil. São Paulo: LTR, 1998. p. 493. 
"O número expressivo de tratados bilaterais de investimentos celebrados por terceiros países justifica, e até mesmo aconselha que o Brasil não fique de fora do rol dos países dispostos a conceder tais garantias, demonstrando à comunidade internacional sua disposição em comprometer-se a dar efetividade aos preceitos de sua Lei Maior" ${ }^{, 103}$.

Quanto à segunda linha argumentativa, sobre a compatibilidade com o ordenamento jurídico brasileiro, Bernadete de Figueiredo Dias afirma que não haveria maiores entraves ao conteúdo dos TBIs brasileiros, visto que "o regime interno se coaduna com as regras e tendências internacionais, com apenas algumas ressalvas específicas"104. Assevera essa posição Arnoldo Wald ao ditar que os princípios gerais e as normas geralmente contidas nos tratados podem assegurar, aos investidores, no plano internacional, direitos que já lhe são garantidos. Segundo o autor, elementos como a responsabilidade objetiva do Estado, a garantia do equilíbrio econômico-financeiro dos contratos administrativos e a indenização justa e prévia nos casos de desapropriação, previstos no direito interno, encontram reforço na proteção jurídica internacional proporcionada pelos acordos de investimento ${ }^{105}$.

A estrutura jurídica do TBI brasileiro nos anos 1990 compreendia questões tradicionais como definições de investimento, investidor e território; promoção e admissão do capital; garantia de tratamento justo e equitativo, tratamento nacional e nação mais favorecida; livre transferência do capital investido; sub-rogações de seguro; indenizações por riscos não comerciais, instabilidades políticas internas, nacionalizações e desapropriações e solução de controvérsias entre investidor e Estado.

Entretanto, importante destacar que apesar de os acordos seguirem um padrão, havia alguns pontos de discrepâncias entre os próprios TBIs. Primeiramente, quanto ao conceito de investidor pessoa jurídica, pois enquanto a maioria dos TBIs combinava os

${ }^{103}$ MAGALHÃES, José Carlos de. Acordos Bilaterais de Promoção e Proteção de investimentos. Revista de Informação Legislativa, Brasília, n.134, ano 34, p.13-18, Brasília, abr./jun., 1997, p.16. Disponível em: $<$ http://www2.senado.leg.br/bdsf/bitstream/handle/id/248/r135-02.pdf? sequence=4>. Acesso em: 2 jul. 2014.

${ }^{104}$ DIAS, Bernadete de Figueiredo. Investimentos estrangeiros no Brasil e no Direito Internacional. Curitiba: Juruá, 2010. p.219.

${ }^{105}$ WALD, Arnoldo. Uma nova visão dos tratados de proteção de investimento e da arbitragem internacional Revista de Arbitragem e Mediação, v.6, n.21, p. 9-29, 2009, p.21. Nesse diapasão, Nádia de Araújo e Lauro de Gama e Souza Jr. afirmam que o TBI brasileiro "não discrepa, na essência, do padrão utilizado por outros países, sejam os industrializados, seja, os países em desenvolvimento. Nem, por outro lado, colidem com os princípios e normas básicos de nossa Constituição". ARAÚJO, Nadia de; SOUZA JÚNIOR, Lauro de Gama e. Os acordos bilaterais de investimento com a participação do brasil e o direito interno - análise das questões jurídicas. In: CASELLA, Paulo Borba; MERCADANTE, Araminta de Azevedo (Coord). Guerra comercial ou integração mundial pelo comércio?: a omc e o brasil. São Paulo: LTR, 1998. p. 494. 
critérios de sede e constituição do investimento sob a legislação local, o TBI com a Dinamarca considera suficiente a sociedade ter sido constituída conforme as leis locais. Já o TBI com o Reino Unido possui definições próprias para pessoas jurídicas inglesas e para as brasileiras e os TBIs com Venezuela e Suíça, preveem que para as empresas controladas por nacionais ou pessoas jurídicas nacionais de um dos Estados Contratantes deveria prevalecer a nacionalidade do controlador $^{106}$. Além disso, no tratado com a Itália, há a referência expressa e específica às empresas públicas ${ }^{107}$.

Sobre os padrões de tratamento do investidor, os TBIs concentram-se no tratamento da nação mais favorecida, tratamento nacional, tratamento justo e equitativo, garantia de proteção e segurança e exceções por participação em organizações econômicas de integração regional ${ }^{108}$. Salienta-se que o TBI firmado com a França, em seu art. $3^{\circ}$ (BRASIL, 1995), prevê rol exemplificativo de violações do padrão justo e equitativo, qual seja:

Em particular, embora não exclusivamente, são considerados como impedimentos a um tratamento justo e equitativo quaisquer restrições à compra e ao transporte de matérias-primas e matérias auxiliares, energia e combustíveis, bem como de meios de produção e de exploração de qualquer espécie, qualquer obstáculo à venda e transporte dos produtos no interior do país e para o exterior, assim como quaisquer outras medidas de efeito análogo ${ }^{109}$.

Em se tratando das indenizações por nacionalização ou desapropriação, os TBIs são claros ao preverem que estas somente são admissíveis quando da existência de necessidade e de interesse público, bem como a indenização deve ser pronta, integral e efetiva, significando que os valores devem ser pagos sem demora e em valores de mercado. Entretanto, os TBIs com Reino Unido, Finlândia e Dinamarca preveem a taxa LIBOR como referência para o pagamento de juros moratórios e compensatórios. Nessa esteira,

${ }^{106}$ ARAÚJO, Nadia de; SOUZA JÚNIOR, Lauro de Gama e. Os acordos bilaterais de investimento com a participação do brasil e o direito interno - análise das questões jurídicas. In: CASELLA, Paulo Borba; MERCADANTE, Araminta de Azevedo (Coord). Guerra comercial ou integração mundial pelo comércio?: a omc e o brasil. São Paulo: LTR, 1998. p. 466.

107 XAVIER JÚNIOR, Ely Caetano. Direito internacional dos investimentos e o Brasil: uma perspectiva a partir do padrão de tratamento justo e equitativo. 2014.279f. Dissertação (Mestrado em Direito). Faculdade de Direito da Universidade Estadual do Rio de Janeiro, Rio de Janeiro, 2014. p.121.

108 SCANDIUCCI FILHO, José Gilberto. O Brasil e os Acordos Bilaterais de Investimento In Regulamentação Internacional dos Investimentos: algumas lições para o Brasil. AMARAL JÚNIOR, Alberto do; SANCHEZ, Michelle Ratton. São Paulo: Aduaneiras, 2007. p. 284-287.

${ }^{109}$ BRASIL. ACORDO entre o Governo da República Federativa do Brasil e o Governo da República Francesa sobre Promoção e Proteção Recíproca de Investimento. Art. $3^{\circ}$. Disponível em: <http://daimre.serpro.gov.br/atos-internacionais/bilaterais/1995/b_17/>. Acesso em: 9 out. 2015. 
observa-se que é uníssono em todos os acordos que caso haja a necessidade de discussão sobre os valores fixados, as partes podem recorrer aos tribunais internos do Estado receptor ${ }^{110}$.

Quanto às sub-rogações de seguros, todos os TBIs asseveram em sua essência a garantia da sub-rogação, contudo, as previsões são distintas nos diversos acordos. No TBI com o Chile se prevê, além das garantias cobertas, também o direito às indenizações não cobertas pela sub-rogação, desde que com ações judiciais já iniciadas. O TBI com Portugal somente concede o direito ao investidor mediante autorização da parte contratante e o acordo com o Reino Unido possui disposições específicas para sub-rogação quando envolvidos bens imóveis na transação.

Particularmente, no que se refere às disposições sobre solução de controvérsias nos TBIs, salienta-se que elas são variadas. Isso pode ser notado ao se analisar o TBI com a Coreia do Sul, em que existindo controvérsia, deve haver, inicialmente, um período de consultas e negociação, e caso estas restem infrutíferas, seguir-se-á para a adjudicação. Para isso, deverá ser realizada uma escolha irreversível (fork-in-the-road) entre a submissão do litígio aos tribunais internos do país anfitrião e a arbitragem internacional ${ }^{111}$. Caso escolhida a arbitragem, esta poderá ser encaminhada para o CIRDI, assim que o Brasil se tornar Parte Contratante da Convenção de Washington e, enquanto não for parte, a disputa poderá seguir para os auspícios do Mecanismo Complementar do CIRDI ${ }^{112}$. Como última opção, a disputa será direcionada à arbitragem ad hoc sendo aplicadas as regras de arbitragem da Comissão das Nações Unidas sobre o Direito do Comércio Internacional (UNCITRAL) ${ }^{113}$.

${ }^{110}$ ARAÚJO, Nadia de; SOUZA JÚNIOR, Lauro de Gama e. Os acordos bilaterais de investimento com a participação do brasil e o direito interno - análise das questões jurídicas. In: CASELLA, Paulo Borba; MERCADANTE, Araminta de Azevedo (Coord). Guerra comercial ou integração mundial pelo comércio?: a omc e o brasil. São Paulo: LTR, 1998. p. 467-468.

${ }^{111}$ Destaca-se que nos TBIs firmados com Bélgica/Luxemburgo, Coreia do Sul, Dinamarca, Finlândia, Reino Unido e Suíça, se o investidor tiver remetido a disputa para os tribunais internos, poderá, antes que seja proferida a sentença, desistir do processo e submeter o caso para a arbitragem mista.

${ }^{112}$ A previsão de submissão ao Mecanismo Complementar caso o Brasil não seja ainda Estado Contratante da Convenção de Washington não se encontra em todos os TBIs. Nos TBIs assinados com Itália e Portugal, caso não seja membro do CIRDI, a arbitragem já se encaminha para a arbitragem ad hoc, com respaldo das regras de arbitragem da UNCITRAL. Ademais, o TBI com a Holanda prevê apenas a opção de conciliação e arbitragem, seja internamente, seja internacionalmente. Cf. XAVIER JÚNIOR, Ely Caetano. Direito internacional dos investimentos e o Brasil: uma perspectiva a partir do padrão de tratamento justo e equitativo. 2014. 279 f. Dissertação (Mestrado em Direito) - Faculdade de Direito da Universidade Estadual do Rio de Janeiro, Rio de Janeiro, 2014. p.125.

${ }^{113}$ BRASIL. Acordo para a Promoção e a Proteção Recíproca de Investimentos entre o Governo da República Federativa do Brasil e o Governo da República da Coréia. Disponível em: $<$ http://investmentpolicyhub.unctad.org/Download/TreatyFile/509>. Acesso em: 9 out. 2015, art. $8^{\circ}$. 
De forma complementar, o TBI com o Reino Unido inclui alternativa jurisdicional à arbitragem investidor-Estado sob a égide do CIRDI, remetendo-a ao foro comercial internacional da Câmara de Comércio Internacional (CCI) de Paris e o TBI com Bélgica/Luxemburgo prevê a mesma opção, além da Câmara de Comércio de Estocolmo (CCE).

Assim, nota-se que as previsões relativas à solução de controvérsias adotadas nos TBIs brasileiros, apesar de variarem de acordo para acordo, seguiram um padrão. Ademais, possivelmente à época imaginava-se que em algum momento o Brasil viria a aderir ao CIRDI, por isso a remissão ao Centro e, além disso, também se pressupunha que o sistema continuaria inerte, com poucos casos registrados até então. Segundo Nádia de Araújo e Lauro Gama e Souza Júnior, a previsão sobre a solução de controvérsias era inovadora do ponto de vista brasileiro ${ }^{114}$, haja vista a resistência construída até então.

\subsubsection{A Resistência Brasileira: Fundamentos e Reflexões}

É oportuno salientar novamente que os tratados bilaterais de investimento firmados pelo Brasil na década de 1990 não foram ratificados pelo Congresso Nacional, tendo sido as propostas para a aprovação de seis TBIs (com Portugal, Chile, Reino Unido, Suíça, França e Alemanha) retiradas da pauta da Câmara dos Deputados em $2002^{115}$. Apesar de terem recebido durante a tramitação na Câmara quase sempre pareceres favoráveis das Comissões de Constituição e Justiça e de Cidadania (CCJC), de Finanças e Tributação (CFT), e de Desenvolvimento Econômico, Indústria e Comércio (CDEIC), a Comissão de Relações Exteriores e de Defesa Nacional (CREDN) apresentava resistência a esses acordos desde o início da tramitação, mesmo que os pareceres tenham indicado a aprovação preliminar dos projetos ${ }^{116}$.

Havia o temor de que a introdução destes tratados no ordenamento jurídico nacional limitasse "a capacidade dos Estados de exercerem efetivamente tal

\footnotetext{
${ }^{114}$ ARAÚJO, Nadia de; SOUZA JÚNIOR, Lauro de Gama e. Os acordos bilaterais de investimento com a participação do brasil e o direito interno - análise das questões jurídicas. In: CASELLA, Paulo Borba; MERCADANTE, Araminta de Azevedo (Coord). Guerra comercial ou integração mundial pelo comércio?: a omc e o brasil. São Paulo: LTR, 1998. p. 466.

${ }^{115}$ Ressalta-se que além dos seis TBIs enviados ao Congresso, o Protocolo de Buenos Aires no âmbito do Mercosul também foi retirado de pauta.

${ }^{116}$ XAVIER JÚNIOR, Ely Caetano. Direito internacional dos investimentos e o Brasil: uma perspectiva a partir do padrão de tratamento justo e equitativo. 2014. 279 f. Dissertação (Mestrado em Direito) Faculdade de Direito da Universidade Estadual do Rio de Janeiro, Rio de Janeiro, 2014. p. 126.
} 
disciplinamento" 117 , e que surgissem contradições entre o objetivo precípuo das legislações internas e a finalidade dos TBIs. A primeira resistência do legislativo a ser elencada corresponde à constitucionalidade dos textos dos acordos sobre a forma de indenização por desapropriação ${ }^{118}$, haja vista que os acordos garantiam o pagamento imediato, em moeda conversível e livremente transferível. Entretanto, apesar de vedadas, exceto por razões de utilidade pública ou interesse social, no Brasil há dois casos específicos em que o investidor nacional não detém o direito de receber pagamentos líquidos e imediatos.

Considera-se, preliminarmente, o caso do art. 182, $\S 4^{\circ}$, inciso III, da Constituição Federal do Brasil sobre o dever do proprietário em atribuir função social à propriedade em solo urbano não edificado, subutilizado ou não utilizado para fins de política de desenvolvimento urbano sob pena de desapropriação, com pagamento mediante títulos da dívida pública de emissão previamente aprovada pelo Senado Federal, com prazo de resgate de até dez anos, em parcelas anuais, iguais e sucessivas, assegurados o valor real da indenização e os juros legais. A outra hipótese envolve a desapropriação por interesse social para fins de reforma agrária, caso o imóvel não esteja cumprindo sua função social. Nesse caso, a desapropriação será feita mediante prévia e justa indenização, em títulos da reforma agrária, com cláusula de preservação do valor real, resgatáveis no prazo de até vinte anos, a partir do segundo ano de sua emissão ${ }^{119}$.

Desse modo, como não houve ressalvas quanto a essas especificidades nos TBIs, o legislativo inferiu que mesmo em conflitos futuros envolvendo desapropriação de imóvel urbano ou rural e, apesar dos dispositivos constitucionais, haveria o risco de os investidores aplicarem o texto acordado, e exigirem, por consequência, o pagamento líquido também para suas controvérsias, o que feriria a Constituição Federal brasileira.

Neste caso, o pagamento da compensação sujeita-se à norma do art. 100 da Constituição brasileira, que prevê que exceto quanto aos créditos de natureza alimentícia, os pagamentos devidos pela Fazenda Federal, Estadual ou Municipal em razão de sentença judiciária deverá respeitar a ordem cronológica de precatórios. Entretanto, ressalta-se que

${ }^{117}$ BRASIL. Parecer da Comissão de Constituição e Justiça e de Redação, de 21 de julho de 1997, ao Projeto de Decreto Legislativo n. 395 de 2000. Diário da Câmara dos Deputados, Brasília, 20 de janeiro de 2000. p. 9.

${ }^{118}$ Salienta-se que o tema expropriação é tratado como desapropriação no Direito Brasileiro.

${ }^{119}$ Conforme aduz Eros Grau, a maior relevância da função social da propriedade se manifesta na concreção das regras do art. $182, \S 2^{\circ}$ - política urbana - e do art. 184 - reforma agrária -, esta última "tão indispensável à realização do fim da ordem econômica quanto à integração e modernização do capitalismo nacional". GRAU, Eros Roberto. A ordem econômica na Constituição de 1988 (interpretação e crítica). 17. ed. São Paulo: Malheiros Editores, 2015. p. 247. 
esta premissa constitucional interferia nas previsões dos TBIs no que concerne ao pagamento "pronto e "imediato", haja vista que a dinâmica do judiciário brasileiro, muitas vezes, se mostrava - e ainda o é - morosa frente à apuração mediante perícia de todos os requisitos para a desapropriação, levando anos para que as indenizações sejam pagas, o que torna impossível, mesmo que previsto em texto constitucional, que a indenização seja pronta e imediata. Ainda, o fato de existir a possibilidade de imissão liminar da posse ao Poder expropriante, em regime de urgência, pode fazer com que o expropriado fique sem o bem e sem o pagamento integral do valor ${ }^{120}$.

Outro ponto sensível levantado pelos congressistas reside na livre transferência de ativos prevista nos TBIs brasileiros, o que foi visto como de extrema gravidade, conforme evidenciado na relatoria desenvolvida pelo deputado Marcos Rolim no âmbito da Comissão de Constituição Justiça e Redação da Câmara, ao se analisar o TBI com a França. Isso se dá em razão do temor frente a ataques especulativos, visto que, conforme explica o deputado supracitado, à época do relatório, experiências traumáticas semelhantes foram vislumbradas nas crises do México, Leste da Ásia e Rússia. Assim, a limitação dos movimentos de capital financeiro deveria ser levada em consideração, mesmo na eventualidade de grave crise cambial e financeira, porém, os acordos de investimento nada mencionam sobre exceções à cláusula de livre transferência.

Além disso, o argumento utilizado pautava-se no art. 28, da Lei $n^{\circ} 4.390 / 64$ (que alterou a Lei $\mathrm{n}^{\circ}$ 4.131/62), relativo à possibilidade de o Conselho da Superintendência da Moeda e do Crédito (SUMOC) impor restrições por prazo limitado à importação e às remessas de reinvestimentos dos capitais estrangeiros quando houvesse grave desequilíbrio no balanço de pagamentos. Logo, a relatoria apontou haver contradição entre a cláusula de livre transferência prevista no APPRI entre Brasil e França e a legislação brasileira interna $^{121}$, fazendo ressalva a ela ${ }^{122}$.

Uma das questões mais relevantes foi a oposição à solução de controvérsias entre investidor e Estado. As primeiras resistências foram identificadas através do

${ }^{120}$ MAGALHÃES, José Carlos de. Acordos Bilaterais de Promoção e Proteção de investimentos. Revista de Informação Legislativa, Brasília, n.134, ano 34, Brasília, p.13-18, abr./jun., 1997. Disponível em: $<$ http://www2.senado.leg.br/bdsf/bitstream/handle/id/248/r135-02.pdf?sequence=4>. Acesso em: 2 jul 2014.

${ }^{121}$ BRASIL. Parecer da Comissão de Constituição e Justiça e de Redação, de 21 de julho de 1997, ao Projeto de Decreto Legislativo n³95 de 2000. Diário da Câmara dos Deputados, Brasília, 20 de janeiro de 2000. p. 15 .

${ }^{122}$ No parecer, inclusive, o deputado Marcos Rolim citou que no parecer do deputado Augusto Viveiros, relator na Comissão de Finanças e Tributação, do APPRI entre Brasil e Suíça, fora apresentada ressalva idêntica, a qual foi aprovada por unanimidade. 
posicionamento do deputado Luiz Gushiken, na Comissão de Relações Exteriores da Câmara, quando da análise do TBI com Portugal, criticando a opção pela arbitragem de investimentos, visto que, na percepção dele, esta significaria a violação ao princípio do esgotamento dos recursos internos antes que se recorra à jurisdição internacional. Além disso, a adoção desse mecanismo de solução de disputas colocaria o Estado brasileiro em patamar de igualdade com o investidor diante de um tribunal arbitral, duas entidades distintas por natureza, o que também violaria sua soberania ${ }^{123}$. Outro fator de preocupação era que o sistema arbitral afastaria a competência do judiciário brasileiro, o que ia contra a previsão constitucional de que a lei não excluirá da apreciação do Poder Judiciário lesão ou ameaça a direito, disposta pelo art. $5^{\circ}, \mathrm{XXXV}$ da Constituição Federal brasileira. Por fim, na opinião do deputado, os textos discriminavam o investidor nacional, pois privilegiavam o investidor estrangeiro em detrimento daquele, o qual não teria acesso ao mesmo tipo de proteção acordada, distorcendo as regras de concorrência e de livre mercado ${ }^{124}$.

Ocorre que pontos de resistência como a visão de que a pactuação de um TBI tratava-se de renúncia à soberania nacional torna-se ultrapassada, conforme aduz Lucas Bento, ao passo que ao se vincular ao tratado, o Estado o faz por expressão de sua autonomia da vontade, o que, desse modo, ao invés de subordinação, configura-se como exercício de sua própria soberania estatal ${ }^{125}$. Além disso, esses argumentos mostraram-se intimamente ligados à doutrina Calvo, com o objetivo da adstrição das disputas exclusivamente ao judiciário interno. Ademais, quanto ao argumento da prevalência do art. $5^{\circ} \mathrm{XXXV}$ da Constituição, conforme assevera Jan Kleinheisterkamp, este prevê acesso à justiça ao indivíduo, como o titular de direitos, não ao Estado ${ }^{126}$.

${ }^{123}$ AZEVEDO, Débora Bithiah de. O capital estrangeiro terá regras estáveis por 25 anos?: os acordos de promoção e proteção de investimentos em tramitação no congresso nacional. Brasília: Cadernos ASLEGIS, v.5, n.4, p.21-30, maio/ago. 2001. p. 27. Disponível em: $<$ http://bd.camara.gov.br/bd/handle/bdcamara/11190>. Acesso em: 2 out. 2013. AZEVEDO, Débora Bithiah de. Os acordos para a promoção e a proteção recíproca de investimentos assinados pelo Brasil. Brasília: Câmara dos Deputados, p. 1-13, 2001. Disponível em: $<$ http://bd.camara.gov.br/bd/bitstream/handle/bdcamara/2542/acordos_promocao_azevedo.pdf?sequence= 1>. Acesso em: 2 maio 2014.

124 BRASIL. Parecer da Comissão de Relações Exteriores e Defesa Nacional [ao Projeto de Decreto Legislativo n 367 de 1996]. Exposição do Deputado Luiz Gushiken. Diário da Câmara dos Deputados, Brasília, 4 de maio de 2000; KLEINHEISTERKAMP, Jan. O Brasil e as disputas com investidores estrangeiros In: CHEREM, Mônica Teresa Costa Sousa; DI SENA JÙNIOR, Roberto (Org.). Comércio internacional e desenvolvimento: uma perspectiva brasileira. São Paulo: Saraiva, p. 157-191, 2004, p. 177-178.

${ }^{125}$ BENTO, Lucas. Time to join the "BIT club"? promoting and protecting Brazilian investments abroad. The American Review of International Arbitration, v. 24, n.2, p. 270-324, 2013. p. 290.

${ }^{126}$ KLEINHEISTERKAMP, Jan. O Brasil e as disputas com investidores estrangeiros In CHEREM, Mônica Teresa Costa Sousa; DI SENA JÙNIOR, Roberto (Org.). Comércio internacional e desenvolvimento: uma perspectiva brasileira. São Paulo: Saraiva, p.157-191, 2004, p.177-178. 


\subsubsection{As Fontes Internas do Direito dos Investimentos no Brasil}

Como exposto acima, o Brasil sempre adotou uma posição de clara resistência aos acordos de promoção e proteção de investimentos, tendo a mesma sido confirmada no início dos anos 2000. Assim, diante da ausência de proteção internacional, o país continuou a contar com seu arcabouço jurídico nacional para disciplinar a matéria ${ }^{127}$. Desse modo, passar-se-á à análise dos dispositivos constitucionais e infraconstitucionais utilizados na regulamentação do tema em domínio nacional.

\subsubsection{Os Investimentos e a Constituição Federal}

No âmbito da Carta Magna brasileira, a menção aos investimentos estrangeiros localiza-se na seção da ordem econômica e financeira, mais especificamente, no capítulo referente aos princípios gerais da atividade econômica. As disposições previstas nesse capítulo orbitam, principalmente, ao redor do art. 170 da Constituição Federal do Brasil, que insculpe uma gama de princípios a serem observados, de modo que a ordem econômica nacional, fundada na valorização do trabalho humano e na livre inciativa, alcance seu objetivo de assegurar a todos uma existência digna, conforme os ditames da justiça social ${ }^{128}$. São eles: (i) soberania nacional; (ii) propriedade privada; (iii) função social da propriedade; (iv) livre concorrência; (v) defesa do consumidor; (vi) defesa do meio ambiente, inclusive mediante tratamento diferenciado conforme o impacto ambiental dos produtos e serviços e de seus processos de elaboração e prestação; (vii) redução das desigualdades regionais e sociais; (viii) busca do pleno emprego; (ix) tratamento favorecido às empresas de pequeno porte constituídas sob as leis brasileiras e que tenham sua sede e administração no País. $O \S$ único também traz à baila previsão de que é assegurado a todos o livre exercício de qualquer atividade econômica, independentemente de autorização de órgãos públicos, salvo nos casos previstos em lei.

\footnotetext{
${ }^{127}$ Nesse aspecto, pontua Eduardo Teixeira Silveira que: "Pelo princípio da soberania, em suma, fica reconhecido o direito do Estado receptor a regulamentar e controlar o investimento estrangeiro, impondolhe para tanto os limites que entender necessários, bem como definindo as políticas a ele relativas de forma a atingir seus objetivos". SILVEIRA, Eduardo Teixeira. A disciplina jurídica do investimento estrangeiro no Brasil e no Direito Internacional. São Paulo: Editora Juarez de Oliveira, 2002. p. 67.

${ }^{128}$ GRAU, Eros Roberto. A ordem econômica na Constituição de 1988 (interpretação e crítica). 17. ed. São Paulo: Malheiros, 2015. p. 225; SALOMÃO FILHO, Calixto. Regulação da atividade econômica (princípios e fundamentos jurídicos). 2. ed. São Paulo: Malheiros, 2008. p. 51-52.
} 
Salienta-se que a Emenda Constitucional n 06 de 15.08.95 conferiu nova redação ao art. 170, inciso IX, haja vista que a redação original previa tratamento favorecido para empresas brasileiras de capital nacional de pequeno porte ${ }^{129}$, e, principalmente, revogou o art. $171^{130}$. O debate acerca do art. 171 e sua revogação reside no fato de que ele estipulava que "empresa brasileira" e "empresa brasileira de capital nacional" eram expressões eufemísticas, já que poderia ser "empresa brasileira" a de capital estrangeiro, desde que constituída sob as leis brasileiras, tendo sua sede e administração no País"131. Segundo o art. 171, no âmbito das empresas brasileiras de capital nacional haveria distinção entre: (i) empresas brasileiras de capital nacional; (ii) empresas brasileiras de capital nacional beneficiárias de proteção e dos benefícios referidos no $\S 1^{\text {o }}$; (iii) empresas brasileiras de capital nacional beneficiárias de tratamento nacional concedidos pelo $\S 2^{\circ} \mathrm{e}$ (iv) empresas brasileiras de capital nacional, de pequeno porte, em respeito ao art. 170, inciso IX.

A doutrina favorável à sua revogação argumentava que o art. 171 obstruiria iniciativas consoantes ao processo de globalização econômica que se implementava, haja vista que o dispositivo previa tratamento diferenciado entre empresas brasileiras em função da origem do seu capital. Nessa esteira, a Exposição de Motivos n³7/95 aduziu em suas justificativas que a proposta inicial de revogação consistia na eliminação da distinção entre empresa brasileira e empresa brasileira com capital nacional e o tratamento nacional concedido à última, portanto, vincular-se-ia a definição de empresa brasileira àquela constituída sob a legislação brasileira e com sede e administração no País ${ }^{132}$.

${ }^{129}$ Segundo Eros Grau: “[...] a Constituição do Brasil é - tem sido - uma Constituição dirigente, e vincula o legislador. E, ainda que tenha sido múltiplas vezes emendada, seu cerne, que identifico fundamentalmente nos preceitos dos seus arts. $3^{\circ}, 1^{\circ}$ e 170, resta intocado". GRAU, Eros Roberto. A ordem econômica na Constituição de 1988 (interpretação e crítica). 17. ed. São Paulo: Malheiros, 2015. p. 225.

${ }^{130} \mathrm{O}$ texto do art. 171 dispunha o seguinte: “Art. 171. São consideradas: I - empresa brasileira a constituída sob as leis brasileiras e que tenha sua sede e administração no País; II - empresa brasileira de capital nacional aquela cujo controle efetivo esteja em caráter permanente sob a titularidade direta ou indireta de pessoas físicas domiciliadas e residentes no País ou de entidades de direito público interno, entendendo-se por controle efetivo da empresa a titularidade da maioria de seu capital votante e o exercício, de fato e de direito, do poder decisório para gerir suas atividades. $\S 1^{\circ}$ - A lei poderá, em relação à empresa brasileira de capital nacional: I - conceder proteção e benefícios especiais temporários para desenvolver atividades consideradas estratégicas para a defesa nacional ou imprescindíveis ao desenvolvimento do País; II estabelecer, sempre que considerar um setor imprescindível ao desenvolvimento tecnológico nacional, entre outras condições e requisitos: a) a exigência de que o controle referido no inciso II do "caput" se estenda às atividades tecnológicas da empresa, assim entendido o exercício, de fato e de direito, do poder decisório para desenvolver ou absorver tecnologia; b) percentuais de participação, no capital, de pessoas físicas domiciliadas e residentes no País ou entidades de direito público interno. $\S 2^{\circ}-\mathrm{Na}$ aquisição de bens e serviços, o Poder Público dará tratamento preferencial, nos termos da lei, à empresa brasileira de capital nacional”. (Revogado pela Emenda Constitucional n ${ }^{\circ} 6$, de 15.08.95)

${ }^{131}$ GRAU, Eros Roberto. op. cit. p. 258.

132 BRASIL. Exposição de Motivos n³7, de 16 de fevereiro de 1995. Diário do Congresso Nacional, Brasília, 15 mar. 1995. Seção I, p. 3246. 
Conforme o entendimento do Ministro Eros Roberto Grau (2015, p. 273):

a revogação do art. 171 atende aos interesses ao lado dos quais se alinhou o Poder Executivo, na persecução de um programa neoliberal. O que pretendia o governo Collor foi obtido no governo Fernando Henrique. Argumentava-se, nessa linha, afirmando que a distinção entre empresa brasileira e empresa brasileira de capital nacional seria perniciosa ao interesse nacional (suponho se tratasse do interesse público nacional), visto que essa distinção criaria obstáculo ao investimento de capitais estrangeiros no Brasil ${ }^{133}$.

Ademais, segundo Arnoldo Wald (2010, p.406) "as modificações sugeridas importavam em estabelecer como princípio geral a igualdade de estrangeiros e brasileiros, pessoas físicas e jurídicas, abolindo qualquer discriminação no plano civil e comercial que não estivesse prevista na Constituição" ${ }^{134}$. Esta centra-se na ideia de que tanto capital estrangeiro quanto nacional merecem tratamento semelhante, sendo vedada discriminação. Por isso, a revogação do art. 171 contribuiu para o encerramento dessa distinção, desaparecendo, portanto, a autorização para discriminação em favor da empresa brasileira de capital nacional, e não mais se admitindo a restrição em função da origem do capital, restaurando-se assim, segundo Bernadete de Figueiredo Dias (2010, p. 141), a isonomia entre elas ${ }^{135}$.

Noutro giro, Denis Borges Barbosa aduz que isso não quer dizer que se atribui igualdade mecânica entre capital estrangeiro e nacional ${ }^{136}$. Eros Roberto Grau afirma que mesmo com essa revogação de permissão forte para incentivos às empresas brasileiras de capital nacional, a Constituição considera a permissão fraca para incentivos setoriais, ou seja, atividades consideradas estratégicas à defesa nacional ou ao desenvolvimento do país - em especial, para setores imprescindíveis ao desenvolvimento tecnológico nacional ${ }^{137}$.

Apesar de a Constituição Federal do Brasil, em seu art. 5, caput, alinhar seu fundamento com a proteção da dignidade humana ao estabelecer igualdade entre brasileiros e estrangeiros residentes via de regra, como exceção, pode o Estado restringir a

${ }^{133}$ GRAU, Eros Roberto. A ordem econômica na Constituição de 1988 (interpretação e crítica). 17. ed. São Paulo: Malheiros, 2015. p. 261. Segundo posicionamento de Eros Roberto Grau, isso, porém, jamais foi demonstrado.

134 WALD, Arnoldo. A evolução do regime constitucional da parceria público-privada e do capital estrangeiro. Revista de Informação Legislativa, Brasília, v. 45, n.179, p. 403-410, 2008. p. 406.

${ }^{135}$ DIAS, Bernadete de Figueiredo. Investimentos estrangeiros no Brasil e no Direito Internacional. Curitiba: Juruá, 2010. p. 141.

${ }^{136}$ BARBOSA, Denis Borges. Direito de acesso do capital estrangeiro. In: RIBEIRO, Marilda Rosado de Sá (Org.) Direito Internacional dos Investimentos. Rio de Janeiro: Renovar, p. 425-457, 2014. p. 450.

${ }^{137}$ Segundo o Eros Grau: "Assim, da revogação da permissão forte no $\S 1^{\circ}$ do art. 171 não decorre proibição da concessão dos incentivos; ela apenas transforma o direito, no sentido de admitir que possa surgir regras que conformem o âmbito da permissão fraca (v.g., uma lei que estabeleça limites para a concessão dos incentivos". GRAU, Eros Roberto. A ordem econômica na Constituição de 1988 (interpretação e crítica). 17. ed. São Paulo: Malheiros, 2015. p. 273. 
entrada do capital estrangeiro no país ${ }^{138}$ ou estabelecer preferências quando lhe parecer conveniente em áreas específicas, em afirmação aos princípios da soberania e do interesse nacional, previstos na Carta Magna, e em proteção a setores estratégicos da economia ${ }^{139}$.

Quanto à legislação ordinária, a doutrina é divergente se esta pode estabelecer exceções. Há posicionamentos que julgam ser exclusivamente do poder constituinte originário ou derivado a competência para tratamento diferenciado do investimento estrangeiro que adentre o Estado, porém, a legislação ordinária ainda teria o condão de instituir restrições ao acesso do capital estrangeiro no país ${ }^{140}$. Contudo, o argumento de que é possível a legislação ordinária atribuir discriminações assevera que não há vedação constitucional de que a legislação ordinária, estando a lei atuando em atenção ao princípio da soberania e do interesse nacional, restrinja o acesso do capital estrangeiro ${ }^{141}$. Ademais, segundo Parecer da Controladoria Geral da União (CGU) - Parecer $n^{\circ}$ CGU/AGU $\mathrm{n}^{\circ} 01 / 2008$, o conceito de capital estrangeiro é distinto de empresa ${ }^{142}$, a qual estava presente no art. 171 da Constituição. Adicionalmente, considera-se ainda, que a própria Lei n4.131/62, em seu art. $2^{\circ}$, dispõe que: “ao capital estrangeiro que se investir no País, será dispensado tratamento jurídico idêntico ao concedido ao capital nacional em igualdade de condições, sendo vedadas quaisquer discriminações não previstas na presente lei" ${ }^{143}$. Assim sendo, "persiste o exercício de controle do direito de acesso do capital estrangeiro através da legislação ordinária"144.

Nesse diapasão, revogando o art. 171 como um todo, desconstitucionalizou-se a definição de empresa brasileira. Assim, ausente conceito na Carta Maga, retornou-se aos

\footnotetext{
${ }^{138}$ MAGALHÃES, José Carlos de. O controle pelo Estado da atividade internacional das empresas privadas. Revista de Informação Legislativa, Brasília, v. 30, n. 119, p.175-192, 1993. p. 182.

${ }^{139}$ XAVIER JÚNIOR, Ely Caetano. Direito internacional dos investimentos e o Brasil: uma perspectiva a partir do padrão de tratamento justo e equitativo. 2014. 279 f. Dissertação (Mestrado em Direito) Faculdade de Direito da Universidade Estadual do Rio de Janeiro, Rio de Janeiro, 2014. p. 139.

${ }^{140}$ BORJA, Célio de Oliveira. O capital estrangeiro no direito brasileiro. Revista do Advogado, v.26, n.88, p.32-42, 2006. p.42.

141 XAVIER JÚNIOR, Ely Caetano. op. cit. p. 137-140.

142 BRASIL. Advocacia Geral da União. Parecer $n^{\circ}$ LA-01, de 03 de outubro de 2008. Diário Oficial [da] República Federativa do Brasil, Brasília, 23 ago. 2010, p.1; FADDA, Fernanda. Regime constitucional e legal dos investimentos estrangeiro no Brasil. In RIBEIRO, Marilda Rosado de Sá (Org.) Direito Internacional dos Investimentos. Rio de Janeiro: Renovar, p. 395-423, 2014.

${ }^{143}$ BRASIL. Lei $\mathrm{n}^{\circ} 4.131$, de 3 de setembro de 1962 . Disciplina a aplicação do capital estrangeiro e as remessas de valores para o exterior e dá outras providências. Diário Oficial [da] República Federativa do Brasil, Brasília, 27 de setembro de 1962. p. 10075.

${ }^{144}$ BARBOSA, Denis Borges. Direito de acesso do capital estrangeiro. In: RIBEIRO, Marilda Rosado de Sá (Org.) Direito Internacional dos Investimentos. Rio de Janeiro: Renovar, p. 425-457, 2014, p. 457.
} 
conceitos previstos na legislação ordinária, em especial, no art. 60 , do Decreto $\mathrm{n}^{\circ} 2.627 / 40$ e no art. 1126 do Código Civil ${ }^{145}$.

Cabe ressaltar que atualmente o art. 172 da Constituição Federal do Brasil representa o fundamento constitucional da regulação do investimento estrangeiro no Brasil $^{146}$. Ele prevê com clareza que "a lei disciplinará, com base no interesse nacional, os investimentos de capital estrangeiro, incentivará os reinvestimentos e regulará a remessa de lucros"147. A delegação de competência ao legislador ordinário impõe a ele o dever de privilegiar o interesse nacional ao reger os investimentos estrangeiros, previsão esta que, segundo Eros Roberto Grau, decorre do princípio da soberania nacional, presente no art. 170 , inciso $\mathrm{I}^{148}$. Ocorre que, até o momento, não houve a edição de nova lei de investimentos, de modo que a lei que ainda vigora é a Lei ${ }^{\circ} 4.131 / 62$, Lei de Remessa de Lucros.

\subsubsection{Restrições Setoriais}

Desse modo, passa-se a expor sobre alguns dispositivos constitucionais que preveem a restrição do acesso aos investimentos estrangeiros a setores específicos, por intermédio de algumas restrições setoriais.

a) Minérios e Minerais Nucleares e seus Derivados

Ressalta-se que o art. 177 da Constituição Federal do Brasil, antigamente, dispunha sobre as atividades emolduradas como monopólio da União. Contudo, após a Emenda Constitucional $n^{\circ} 9$ de 1995, houve mudança na redação do referido artigo, e seu $\S$ $1^{\circ}$ passou a estabelecer que a União poderá contratar com empresas estatais ou privadas para a realização das atividades previstas nos incisos I a IV, que englobam: (i) a pesquisa e a lavra de jazidas de petróleo e gás natural e outros hidrocarbonetos fluidos; (ii) a refinação

${ }^{145}$ XAVIER JÚNIOR, Ely Caetano. Direito internacional dos investimentos e o Brasil: uma perspectiva a partir do padrão de tratamento justo e equitativo. 2014. 279 f. Dissertação (Mestrado em Direito) Faculdade de Direito da Universidade Estadual do Rio de Janeiro, Rio de Janeiro, 2014. f.135.

${ }^{146}$ FADDA, Fernanda. Regime constitucional e legal dos investimentos estrangeiro no Brasil. In: RIBEIRO, Marilda Rosado de Sá (Org.) Direito Internacional dos Investimentos. Rio de Janeiro: Renovar, p. 395423, 2014, p. 408.

${ }^{147}$ BRASIL. Constituição (1988). Constituição da República Federativa do Brasil. Brasília: Senado, 1988. art. 172.

${ }^{148}$ GRAU, Eros Roberto. A ordem econômica na Constituição de 1988 (interpretação e crítica). 17. ed. São Paulo: Malheiros, 2015. p. 225. SALOMÃO FILHO, Calixto. Regulação da atividade econômica (princípios e fundamentos jurídicos). 2 ed. São Paulo: Malheiros, 2008. p. 275. 
do petróleo nacional ou estrangeiro; (iii) a importação e exportação dos produtos e derivados básicos resultantes de atividades de pesquisa e lavra de jazidas e refinação de petróleo, gás natural e hidrocarbonetos e (iv) o transporte marítimo do petróleo bruto de origem nacional ou de derivados básicos de petróleo produzidos no País, bem como o transporte, por meio de conduto, de petróleo bruto, seus derivados e gás natural de qualquer origem.

Entretanto, no que tange ao inciso $\mathrm{V}$, dispõe-se que a pesquisa, a lavra, o enriquecimento, o reprocessamento, a industrialização e o comércio de minérios e minerais nucleares e seus derivados, com exceção dos radioisótopos cuja produção, comercialização e utilização poderão ser autorizadas sob regime de permissão, são monopólio absoluto da União. Isto ocorre, principalmente, em razão do alto potencial lesivo das substâncias nucleares, portanto, visa-se preservar a segurança nacional. Por isso, a restrição não atinge somente o capital estrangeiro, mas o capital privado de forma geral ${ }^{149}$.

b) Assistência à Saúde

Destaca-se que, no art. 199, $\S 3^{\circ}$ da Constituição Federal do Brasil, há proibição quanto à participação direta ou indireta de empresas ou capitais estrangeiros nas atividades de assistência à saúde, porém, admitindo-se exceções previstas em legislação ordinária. Nesse diapasão, a Lei $n^{\circ} 8.080 / 90$, que dispõe sobre as condições para a promoção, proteção e recuperação da saúde, a organização e o funcionamento dos serviços correspondentes, prevê exceção no que tange à assistência à saúde realizada por meio de doações de organismos internacionais vinculados às Nações Unidas, entidades de cooperação técnica e de financiamento e empréstimos, mediante autorização do órgão diretivo responsável vinculado ao Sistema Único de Saúde (SUS).

Ademais, segundo a Lei ${ }^{\circ} 9.656 / 98$, é permitido acesso do capital estrangeiro aos planos de saúde privados e aos serviços de seguro de saúde privados, desde que haja reciprocidade no Estado de origem do investidor, conforme Decreto-lei $n^{\circ} 73 / 66^{150}$.

${ }^{149}$ DIAS, Bernadete de Figueiredo. Investimentos estrangeiros no Brasil e no Direito Internacional. Curitiba: Juruá, 2010. p. 99; FADDA, Fernanda. Regime constitucional e legal dos investimentos estrangeiro no Brasil. In: RIBEIRO, Marilda Rosado de Sá (Org.) Direito Internacional dos Investimentos. Rio de Janeiro: Renovar, p. 395-423, 2014..p. 398.

${ }^{150}$ DIAS, Bernadete de Figueiredo. Ibid., p. 101-102. 
c) Empresa Jornalística, Radiodifusão Sonora e de Sons e Imagens

No que diz respeito à propriedade de empresa jornalística e de radiodifusão sonora e de sons e imagens, os direitos insculpidos no art. 222 da Constituição Federal antigamente vedavam a participação de pessoas jurídicas em seu capital social, a não ser que se tratassem de partido político e de sociedade com capital pertencente exclusivamente e nominalmente a brasileiros, com participação limitada a $30 \%$ do capital social e sem direito a voto.

Com o advento da Emenda Constitucional n³6 de 2002, o art. 222 passou a permitir a participação de pessoas jurídicas no capital social de tais empresas, mantendo algumas restrições. A primeira delas refere-se à participação de brasileiros natos ou naturalizados há mais de dez anos, a qual deve corresponder a 70\% do capital social e do capital votante das empresas jornalísticas e de radiodifusão, restando ao investidor estrangeiro, portanto, o limite de participação de até 30\% do capital social e votante.

A propriedade das empresas jornalísticas, de radiodifusão sonora e de sons e imagens continuam privativas a brasileiros natos ou naturalizados há mais de dez anos, os quais são juridicamente competentes pela gestão e responsabilidade das atividades, pelo conteúdo da programação, pela edição e direção da programação difundida.

d) Setor Financeiro

Antes da Emenda Constitucional no 40 de 2003, o art. 192 da Constituição Federal do Brasil outorgava à lei complementar a regulamentação da participação de capital estrangeiro nas instituições do sistema financeiro nacional, levando em consideração os interesses nacionais e os acordos internacionais. Após a referida emenda, manteve-se a necessidade de edição de lei complementar, porém, enquanto esta não é editada, o art. 52 do Ato das Disposições Constitucionais Transitórias (ADCT) estabelece que até serem fixadas as condições por lei complementar, serão vedadas a instalação de novas agências de instituições financeiras domiciliadas no exterior, bem como proibido o aumento do percentual de participação, no capital das instituições financeiras com sede no Brasil, de pessoas físicas ou jurídicas residentes ou domiciliadas no exterior. Ressalta-se que frente a essas proibições, algumas instituições financeiras conseguiram acesso ao mercado nacional por intermédio de aquisições de instituições financeiras brasileiras. Por fim, a proibição 
não se aplica às autorizações provenientes de acordos internacionais, de reciprocidade ou de interesses governamentais do Estado brasileiro ${ }^{151}$.

e) Mineração e Hidroeletricidade

$\mathrm{O}$ art. 176 da Constituição Federal do Brasil instituía, em sua redação original, que era reservado a brasileiros ou à empresa brasileira de capital nacional as atividades de pesquisa e a lavra de recursos minerais e de aproveitamento dos potenciais de energia hidráulica. Com a emenda constitucional $n^{\circ} 6$ de 1995, houve a alteração da redação do art. 171, como já mencionado, o que corroborou à adequação do art. 176, que passou a admitir a realização de tais atividades por brasileiros ou empresa constituída sob as leis brasileiras, com sede e administração no Brasil. Atualmente, o art. 176, em seu $\S 1^{\circ}$, mantém a vedação de se efetuar atividades relacionadas no artigo por empresa estrangeira, no entanto, não é imposta proibição no que se refere à origem do capital da empresa brasileira estabelecida e com sede no país.

f) Transporte Aquaviário

A antiga redação do art. 178 da Constituição Federal do Brasil versava sobre restrições à navegação de cabotagem e interior por embarcações estrangeiras e à nacionalidade dos tripulantes, armadores, proprietários e comandantes de embarcações nacionais, exceto em caso de necessidade pública. Com a emenda constitucional $\mathrm{n}^{\circ} 7 \mathrm{de}$ 1995, o $\S 1^{\circ}$, do art. 178, admitiu que as atividades pudessem ser realizadas por estrangeiros, atendidas as condições da legislação de transporte aquático, Lei $n^{\circ}$ 9.432/97, para o transporte de cabotagem e para a navegação interior, como é o caso, por exemplo, da exigência da nacionalidade brasileira para o comandante e dois terços da tripulação, prevista no art. $4^{\circ}$ da Lei $n^{\circ} 9.432 / 97$.

g) Aquisição ou Arrendamento de Propriedade Rural

${ }^{151}$ XAVIER JÚNIOR, Ely Caetano. Direito internacional dos investimentos e o Brasil: uma perspectiva a partir do padrão de tratamento justo e equitativo. 2014. 279 f. Dissertação (Mestrado em Direito) Faculdade de Direito da Universidade Estadual do Rio de Janeiro, Rio de Janeiro, 2014. f. 142-143. Além disso, segundo Ely Caetano Xavier Júnior, a proibição do art. 52 não abrange as sociedades seguradoras, conforme estabelecido no Parecer AGU/LA-01/96, adotado pelo Parecer GQ-104/96. Cf. BRASIL. Advocacia Geral da União. Parecer n ${ }^{\circ} \mathrm{GQ}-104$, de 29 fevereiro 1996. Diário Oficial [da] República Federativa do Brasil, Brasília, 11 de junho de 1996. 
O art. 190 da Constituição Federal do Brasil estipula que a lei regulará e limitará a aquisição ou arrendamento de propriedade rural por pessoa física ou jurídica estrangeira. No entanto, esta lei ainda não foi editada pelo Poder Legislativo, permanecendo em vigor até o momento a Lei ${ }^{\circ} 5.709 / 71$, que estabelece diversas restrições à aquisição de imóvel rural por estrangeiros residentes no Brasil ou por pessoa jurídica estrangeira autorizada a funcionar no país. Dentre as restrições cita-se o tamanho da propriedade; percentual em loteamentos rurais realizados por empresas particulares de colonização; vinculação dos imóveis rurais necessariamente aos objetivos estatutários das pessoas jurídicas estrangeiras ou brasileiras a elas equiparadas, dentre outras disposições previstas em lei.

Nesse diapasão, o art. $1^{\circ}$ da lei supracitada expande as restrições insculpidas à "pessoa jurídica brasileira da qual participem, a qualquer título, pessoas estrangeiras físicas ou jurídicas que tenham a maioria de seu capital social" 152 . Ocorre que, com a revogação do art. 171, isto foi questionado em razão da distinção realizada em sua redação original.

Segundo parecer da Advocacia Geral da União (AGU), à época, ao ser consultada sobre a constitucionalidade do artigo, esta pronunciou-se no Parecer $n^{\circ}$ AGU/LA-04/94, adotado pelo Parecer $n^{\circ}$ GQ-22/94, que o art. $1^{\circ}$ da Lei $n^{\circ} 5.709 / 71$ não havia sido recepcionado pela Constituição. Contudo, com a revogação do art. 171 da Constituição, foi determinado o reexame do parecer, quando se concluiu que seria impossível a repristinação da norma jurídica. Assim, o novo Parecer n AGU/LA-01/97, adotado pelo Parecer n GQ181/98, manteve o entendimento do parecer anterior. Entretanto, em 2008, a AGU reformou a orientação anterior, por meio do Parecer CGU/AGU n ${ }^{\circ}$ 01/2008, adotado pelo Parecer $n^{\circ}$ LA-01/2010, que entendeu pela recepção do $\S 1^{\circ}$, do $\operatorname{art.~}^{\circ}$, da Lei $n^{\circ} 5.709 / 71$ pela Constituição ${ }^{153}$.

Segundo Fernanda Fadda (2014, p.403), “a conclusão do Parecer CGU/AGU n 01/2008, ao sujeitar a empresa brasileira sob controle estrangeiro às mesmas regras impostas à empresa estrangeira para a aquisição de imóvel rural, foi alvo de várias

${ }^{152}$ BRASIL. Lei n 5.709 de 7 de outubro de 1971. Regula a aquisição de imóvel rural por estrangeiro residente no país ou pessoa jurídica estrangeira autorizada a funcionar no Brasil, e dá outras providências. Diário Oficial [da] República Federativa do Brasil, Brasília, 11 de outubro de 1971.

${ }^{153}$ XAVIER JÚNIOR, Ely Caetano. Direito internacional dos investimentos e o Brasil: uma perspectiva a partir do padrão de tratamento justo e equitativo. 2014. 279 f. Dissertação (Mestrado em Direito) Faculdade de Direito da Universidade Estadual do Rio de Janeiro, Rio de Janeiro, 2014. p. 147. 
críticas" ${ }^{154}$. Estas concentravam-se principalmente na literalidade do art. 190 da Constituição, que previa limitações à pessoa física ou jurídica estrangeira, contudo, um dos méritos do parecer foi "enfrentar a questão pertinente à possibilidade de lei ordinária dispor sobre restrições à empresa brasileira de capital estrangeiro, além daquelas previstas no texto constitucional, independentemente da revogação do art. 171 da Constituição"155.

\subsubsection{Legislação Infraconstitucional Brasileira sobre Investimentos Estrangeiros}

O regime jurídico do investimento estrangeiro no Brasil é regulamentado pela Lei $n^{\circ} 4.131 / 62$, mais conhecida por Lei da Remessa de Lucros ou Lei do Capital Estrangeiro. Destaca-se que a lei de 1962 foi alterada pela Lei $\mathrm{n}^{\circ} 4.390 / 64$ e, posteriormente, regulamentada pelo Decreto ${ }^{\circ} 55.762 / 65$. Esta legislação foi elaborada com o escopo de garantir segurança ao capital estrangeiro e tratamento não-discriminatório, objetivando atraí-lo e estimulá-lo. Ao mesmo tempo, a legislação procura coibir abusos e tutelar o interesse nacional ${ }^{156}$, de modo a evitar a evasão de divisas e a transferência excessiva de recursos ao exterior, assegurando aos investidores estrangeiros o repatriamento do capital investido no Brasil e seus rendimentos ${ }^{157}$.

Desse modo, em razão de sua extensão e detalhamento, o objetivo da análise a seguir não é esgotar todo o conteúdo da Lei $\mathrm{n}^{\circ}$ 4.131/62, mas sim destacar apenas algumas de suas disposições mais relevantes para o presente estudo.

a) Conceito de Capital Estrangeiro

$\mathrm{O}$ art. $1^{\circ}$ da Lei $\mathrm{n}^{\circ} 4.131 / 62$ estabelece o conceito de capital estrangeiro, o que segundo Washington Peluso Albino de Sousa, consiste na maior contribuição da lei em

\footnotetext{
${ }^{154}$ FADDA, Fernanda. Regime constitucional e legal dos investimentos estrangeiro no Brasil. In: RIBEIRO, Marilda Rosado de Sá (Org.). Direito Internacional dos Investimentos. Rio de Janeiro: Renovar, p. 395-423, 2014. p. 403.

${ }^{155}$ FADDA, Fernanda. Regime constitucional e legal dos investimentos estrangeiro no Brasil. In: RIBEIRO, Marilda Rosado de Sá (Org.). Direito Internacional dos Investimentos. Rio de Janeiro: Renovar, p. 395-423, 2014. p. 403.

${ }^{156}$ DIAS, Bernadete de Figueiredo. Investimentos estrangeiros no Brasil e no Direito Internacional. Curitiba: Juruá, 2010. p. 82.

157 Ademais, ressalta-se que a lei autoriza o Banco Central do Brasil (BCB) a emitir regulamentos administrativos referentes à matéria.
} 
termos substantivos ${ }^{158}$. Para esta diretriz, consideram-se capitais estrangeiros os bens, máquinas e equipamentos ingressados no Brasil do exterior, sem dispêndio inicial de divisas, destinados à produção de bens ou serviços, e os recursos financeiros ou monetários, que entrarem no país para aplicação em atividades econômicas desde que, em ambas as hipóteses, pertençam a pessoas físicas ou jurídicas residentes, domiciliadas ou com sede no exterior ${ }^{159}$. Salienta-se que quanto aos bens, esses podem corresponder aos bens móveis e imóveis, corpóreos e incorpóreos e os direitos de propriedade intelectual e industrial $^{160}$. Conforme assevera Luiz Olavo Baptista (1998), conhecimentos tecnológicos, marcas, patentes devem preencher determinados requisitos, como é o caso do estabelecimento de seu valor, através de avaliação do contrato de cessão de marcas ou patentes, ou processo devidamente averbado no Instituto Nacional de Propriedade Intelectual (INPI), como condição para o registro. Já quanto aos recursos econômicos ou financeiros, estes podem se dar na forma de dinheiro ou crédito ou, também, na hipótese de empréstimos e financiamentos em moeda estrangeira ${ }^{161}$.

Nesse prisma, a doutrina não é uníssona no estabelecimento das categorias de operações econômicas que constituem um investimento estrangeiro. Para Eduardo Teixeira Silveira, os investimentos estrangeiros se manifestam por meio de: (i) capital de empreendimento, realizado em setor produtivo da economia de modo direto mediante participação em sociedade brasileira, através da concessão de dinheiro ou bens de capital; (ii) capital de portfólio, que corresponde ao investimento em valores imobiliários e ativos reais através da aquisição de ações em bolsa de participação acionária em empresa nacional, o que é caracterizado como investimento de forma indireta; (iii) capital financeiro, por intermédio de empréstimos e financiamentos, considerados investimentos diretos quando realizados entre empresas de um mesmo grupo e indireto nos demais casos e (iv) capital tecnológico, advindo de transferências tecnológicas, tais como licenças de uso de marca, patentes, prestação de serviços técnicos especializados, dentre outros ${ }^{162}$.

\footnotetext{
${ }^{158}$ SILVEIRA, Eduardo Teixeira. A disciplina jurídica do investimento estrangeiro no Brasil e no direito internacional. São Paulo: Editora Juarez de Oliveira, 2002. p. 98.

${ }^{159}$ BRASIL. Lei ${ }^{\circ} 4.131$ de 1962 . Disciplina a aplicação do capital estrangeiro e as remessas de valores para o exterior e dá outras providências. Diário Oficial [da] República Federativa do Brasil, Brasília, 27 set. 1962. p. 10075, art. $1^{\circ}$.

${ }^{160}$ DIAS, Bernadete de Figueiredo. Investimentos estrangeiros no Brasil e no Direito Internacional. Curitiba: Juruá, 2010. p. 30.

${ }^{161}$ SILVEIRA, Eduardo Teixeira. A disciplina jurídica do investimento estrangeiro no Brasil e no direito internacional. São Paulo: Editora Juarez de Oliveira, 2002. p. 113.

${ }^{162}$ SILVEIRA, Eduardo Teixeira. Ibid, p.37.
} 
Egberto Lacerda Teixeira (2014, p. 152) traz à baila outra classificação, envolvendo quatro elementos: (i) investimentos diretos sob a forma de bens de capital, máquinas, equipamentos; (ii) investimentos diretos sob a forma de recursos econômicos ou financeiros, ou seja, dinheiro e crédito; (iii) empréstimos e financiamentos em moeda estrangeira; (iv) aplicação tecnológica, consubstanciada em contratos de assistência técnica, administrativa, científica ou profissional, contratos de licenças de marcas, patentes e processos industriais ${ }^{163}$. Por fim, Luiz Olavo Baptista pontua que investimentos abrangem: (i) investimentos em moeda; (ii) investimentos em bens ${ }^{164}$ e serviços e (iii) empréstimos e outros créditos ${ }^{165}$.

Importante ressaltar que o legislador jamais efetuou distinção entre investimento direto e indireto. O primeiro corresponde ao investimento dotado de relação econômica durável, que poderá ser também uma relação de controle, haja vista que o investidor poderá adquirir quotas suficientes para obter o controle da empresa. O segundo diz respeito ao investimento especulativo, em que não há característica de durabilidade e o investidor não objetiva o controle da empresa como forma de investimento, mas apenas auferir os lucros decorrentes de sua valorização no mercado especulativo ${ }^{166}$.

Essa diferença entre investimento direto e indireto é abordada na Resolução do Conselho Monetário Nacional $(\mathrm{CMN}) \mathrm{n}^{\circ}$ 3.844, de 23 de março de 2010, que estipula, em seu art. $1^{\circ}, \S 1^{\circ}$, sobre as modalidades de investimento estrangeiro, quais sejam: (i) investimento estrangeiro direto; (ii) crédito externo, inclusive arrendamento mercantil financeiro externo; (iii) royalties, serviços técnicos e assemelhados, arrendamento mercantil operacional externo, aluguel e fretamento; (iv) garantias prestadas por organismos internacionais; (v) capital em moeda nacional, nos termos da Lei $n^{\circ} 11.371$, de 28 de novembro de $2006^{167}$. Para a mesma normativa, investimento direto significa a participação de investidor não residente no capital social da empresa receptora, integralizada ou adquirida na forma da legislação em vigor, e o capital destacado de

${ }^{163}$ TEIXEIRA, Egberto Lacerda. Regime jurídico-fiscal dos capitais estrangeiros no Brasil. Revista Forense, Rio de Janeior, v. 248, 1974. p. 456.

${ }^{164}$ Aqui incluídos também, como já enunciado, os direitos de propriedade intelectual e industrial.

${ }^{165}$ BAPTISTA, Luiz Olavo. Investimentos Internacionais no Direito Comparado e Brasileiro. Porto Alegre: Livraria do advogado, 1998. p. 78-81.

${ }^{166}$ DIAS, Bernadete de Figueiredo. Investimentos estrangeiros no Brasil e no Direito Internacional. Curitiba: Juruá, 2010. p. 40-41.

${ }^{167}$ BRASIL. Conselho Monetário Nacional. Resolução n 3.844, de 23 de março de 2010. Dispõe sobre o capital estrangeiro no País e seu registro no Banco Central do Brasil, e dá outras providências. Diário Oficial [da] República Federativa do Brasil, Brasília, 26 de março de 2010. art. $1^{\text {o }}$. 
empresa estrangeira autorizada a operar no Brasil e a capitalização do valor correspondente a bens de propriedade de não residentes, importados sem obrigatoriedade de pagamento ${ }^{168}$.

Além disso, no que se refere à titularidade do investimento estrangeiro, previu-se na Lei $\mathrm{n}^{\circ} 4.131 / 62$ a adoção do critério do domicílio do investidor para se definir a origem do investimento como elemento de conexão, ao invés do critério da nacionalidade. A principal finalidade deste critério "é permitir que a autoridade monetária tenha certo grau de controle sobre o fluxo de divisas no país, bem como obtenha dados estatísticos referentes à origem do investimento e à área de atividade econômica do destinatário"169. Nesse ínterim, o capital brasileiro domiciliado no exterior pode também ser considerado investimento estrangeiro, haja vista que o domicílio contido na referida lei corresponde ao domicílio civil, qualificado pelos elementos presentes na legislação tributária nacional ${ }^{170}$. Outra disposição importante prevista no art. $1^{\circ}$ da Lei $n^{\circ} 4.131 / 62$ é o critério da destinação econômica, haja vista que o investimento deve ser direcionado à produção de bens e serviços ou outras atividades lucrativas ${ }^{171}$.

Interessante observar que há nesse conceito um elemento temporal que permitirá efetuar a distinção entre o que pode ser considerado investimento, haja visa que a noção de investimento prevê um retorno do mesmo, o qual é limitado ao sucesso do empreendimento, que desencadeará não apenas no retorno do capital empregado, como também do lucro, não sendo normalmente imediato ${ }^{172}$.

Adicionalmente, tem-se que os reinvestimentos, em uma interpretação extensiva do art. $7^{\circ}$ da lei $\mathrm{n}^{\circ}$ 4.131/62, também podem ser considerados investimentos. Estes

${ }^{168}$ BRASIL. Conselho Monetário Nacional. Ibid., 2010. Anexo I, art. $5^{\circ}$ e $8^{\circ}$. Ademais, salienta-se que a Circular do $\mathrm{BCB}$ n$^{\circ} 3.689$ de 16 de dezembro de 2013 dispõe sobre a participação do investidor não residente no capital social de empresa receptora. Esta elenca os valores provenientes de ingresso de moeda e de bens no país; conversão em investimento de créditos passíveis de gerar transferências financeiras para o exterior; permuta de participação societária; conferência de quotas ou ações; rendimentos auferidos por investidor não residente em empresas receptoras; alienação a nacionais, redução de capital para restituição a sócio ou acervo líquido resultante de liquidação de empresa receptora. Cf. BRASIL. Conselho Monetário Nacional. Resolução n 3.689, de 16 de dezembro de 2013. Regulamenta, no âmbito do Banco Central do Brasil, as disposições sobre o capital estrangeiro no País e sobre o capital brasileiro no exterior. Diário Oficial [da] República Federativa do Brasil, Brasília, 17 de dezembro de 2013. art. 33.

${ }^{169}$ XAVIER JÚNIOR, Ely Caetano. Direito internacional dos investimentos e o Brasil: uma perspectiva a partir do padrão de tratamento justo e equitativo. 2014. 279 f. Dissertação (Mestrado em Direito) Faculdade de Direito da Universidade Estadual do Rio de Janeiro, Rio de Janeiro, 2014. p. 155.

${ }^{170}$ BAPTISTA, Luiz Olavo. Investimentos Internacionais no Direito Comparado e Brasileiro. Porto Alegre: Livraria do advogado, 1998. p. 64.

${ }^{171}$ BAPTISTA, Luiz Olavo. Ibid. p. 52-53. De acordo com Luiz Olavo Baptista: “As remessas para cá feitas para fins criativos, doação, auxílio ou outros fins que não sejam a atividade econômica, não gozam da proteção da leu como investimentos". BAPTISTA, Luiz Olavo. Ibid., p. 53.

172 Entretanto, há caso em que se prevê a expectativa de retorno rápido do investimento, quando das aplicações financeiras, chanceladas no Brasil pelo Decreto-Lei n ${ }^{\circ} .986 / 82$. 
consistem nas quantias auferidas por empresas estabelecidas no País e atribuídos a residentes e domiciliados no exterior, que poderiam ser legalmente remetidas ao estrangeiro como rendimentos de capital, porém, são reinvestidas nas mesmas empresas de que procedem ou na economia interna. Faz-se necessário que sejam, assim como os investimentos, registrados junto ao Banco Central. De acordo com Resolução CMN ${ }^{\circ}$ 3.822 , de 23 de março de 2010, as capitalizações de lucros, dividendos, juros sobre capital próprio e reservas de lucros - quando efetuadas na empresa receptora em que foram produzidos os recursos - são tidas como reinvestimentos, devendo ser registradas na moeda do Estado ao qual deveriam ter sido remetidas, ou no caso de investimento registrado em moeda nacional, em reais ${ }^{173}$.

b) Ingresso e Registro

Segundo art. $3^{\circ}$ da Lei $n^{\circ} 4.131 / 62$ e art. $3^{\circ}$, § único da Resolução CMN n 3.844 de 23 de março de 2010, assim que o capital estrangeiro aportar em território nacional, este deve ser registrado obrigatoriamente junto ao Banco Central do Brasil (BCB), órgão responsável pelo controle dos fluxos de capital, no prazo de 30 dias contados do evento que lhe deu origem, tal como a entrada do capital estrangeiro na forma de investimento direto ou de empréstimo, em moeda ou bens; as remessas enviadas para o exterior como retorno de capitais ou rendimentos, lucros, dividendos, juros, amortizações, royalties ou qualquer outro título que corresponda a transferência de capitais investidos para o exterior; os reinvestimentos de lucros dos capitais estrangeiros e as alterações do valor monetário do capital das empresas ${ }^{174}$. No entanto, se o investimento é efetuado mediante bens tangíveis, o registro poderá ser realizado em até 90 dias após o desembaraço aduaneiro. A atenção ao prazo de registro se torna relevante ao passo que, consequentemente, tem efeito a partir da data de ingresso efetivo do capital, logo, se realizado fora do prazo, só passa a ter efeito a partir da data em que for efetivado.

${ }^{173}$ XAVIER JÚNIOR, Ely Caetano. Direito internacional dos investimentos e o Brasil: uma perspectiva a partir do padrão de tratamento justo e equitativo. 2014. 279 f. Dissertação (Mestrado em Direito) Faculdade de Direito da Universidade Estadual do Rio de Janeiro, Rio de Janeiro, 2014. p. 156. BRASIL. Conselho Monetário Nacional. Resolução $n^{\circ} 3.844$, de 23 de março de 2010. Dispõe sobre o capital estrangeiro no País e seu registro no Banco Central do Brasil, e dá outras providências. Diário Oficial [da] República Federativa do Brasil, Brasília, 26 mar. 2010.

174 SILVEIRA, Eduardo Teixeira. A disciplina jurídica do investimento estrangeiro no Brasil e no direito internacional. São Paulo: Editora Juarez de Oliveira, 2002. p. 116. Entretanto, o rol previsto no art. $3^{\circ}$ não é taxativo, podendo outras operações previstas na Resolução CMN n³.844 de 23 de março de 2010 e na Circular do $\mathrm{BCB}$ n 3.689 de 16 de dezembro de 2013 serem passíveis de registro. 
O registro deve ser efetuado na moeda do país de origem, segundo art. $4^{\circ}$ da Lei $\mathrm{n}^{\circ} 4.131 / 62$, contudo, o Decreto $\mathrm{n}^{\circ} 55.762 / 65$ estipulou que o registro fosse realizado na moeda estrangeira efetivamente ingressada no país, conteúdo que foi reproduzido na Resolução CMN n ${ }^{\circ} 11.371 / 06$, permitindo o registro em moeda estrangeira ${ }^{175}$. Apesar de o decreto ser hierarquicamente inferior, prevalecendo formalmente a lei, o que se vê na prática é a aplicação do conteúdo do decreto, que inclusive tem sido alterado por portarias e circulares do BCB. Essa situação tem se perpetrado em razão de os investidores, em sua maioria, temerem ofender ou criar uma situação em que sejam mal vistos pelo BCB se ingressarem no judiciário ${ }^{176}$.

Já quanto ao registro do reinvestimento, este era, na redação original da Lei ${ }^{\circ}$ 4.131/62, realizado em moeda nacional, porém, com a alteração da Lei $n^{\circ}$ 4.390/64, passou-se a admitir o cálculo do reinvestimento em moeda do país para onde poderia ter sido enviado o capital reinvestido. Essa mudança se deu, principalmente, em razão das críticas doutrinárias que aventavam que o investidor poderia ser prejudicado caso houvesse desvalorização cambial. Assim, o reinvestimento passou a ser registrado tanto em moeda estrangeira quanto em moeda nacional, este para fins de controle de conversão ${ }^{177}$.

O registro poderá ser realizado por meio eletrônico, de forma declaratória, através do Registro Declaratório Eletrônico (RDE) do Sistema de Informações do Banco Central (SISBACEN), sob inteira responsabilidade dos próprios interessados com relação à correção, completude e tempestividade das informações prestadas ${ }^{178}$. Caso descumprido qualquer dos prazos, fica instituída aplicação de multa pelo $\mathrm{BCB}^{179}$, conforme previsto no art. 58 da lei supracitada, sendo seus critérios delimitados pela Resolução CMN nº4.101, de 28 de junho de 2012.

Ademais, uma questão que se aventa é a do capital contaminado, aquele investimento juridicamente pertencente ao investidor não residente, porém, que não fora registrado no $\mathrm{BCB}$, sendo impossível a sua identificação de ingresso. Entretanto, segundo o art. $5^{\circ}$, da Lei $\mathrm{n}^{\circ} 11.371 / 2006$, fica sujeito a registro em moeda nacional no BCB o

\footnotetext{
${ }^{175}$ XAVIER JÚNIOR, Ely Caetano. Op. cit., p. 156.

${ }^{176}$ BAPTISTA, Luiz Olavo. Investimentos Internacionais no Direito Comparado e Brasileiro. Porto Alegre: Livraria do advogado, 1998. p. 86.

${ }^{177}$ BAPTISTA, Luiz Olavo. Ibid., p. 86-87.

${ }^{178}$ SILVEIRA, Eduardo Teixeira. A disciplina jurídica do investimento estrangeiro no Brasil e no direito internacional. São Paulo: Editora Juarez de Oliveira, 2002, p.118. Ademais, ressalta-se não haver a necessidade de prévia análise do $\mathrm{BCB}$ da destinação do capital estrangeiro na economia nacional para o registro.

${ }^{179}$ SILVEIRA, Eduardo Teixeira. Ibid., p.114-115.
} 
capital estrangeiro investido em pessoas jurídicas no País ainda não registrado e que não esteja sujeito a nenhuma outra forma de registo perante o BCB. Portanto, segundo esta lei, caso o capital não tenha sido registrado deve ocorrer apenas a regularização do capital pendente de registo, o que elimina a figura do capital contaminado ${ }^{180}$.

c) Tratamento entre capital nacional e capital estrangeiro

Outra previsão importante desta lei é a estipulação do princípio da isonomia entre investimento nacional e investimento estrangeiro. A redação do art. $2^{\circ}$ prevê que ao capital estrangeiro investido no País, "será dispensado tratamento jurídico idêntico ao concedido ao capital nacional em igualdade de condições, sendo vedadas quaisquer discriminações não previstas na presente lei" ${ }^{\text {181. }}$.

Nesse sentido, o art. $5^{\circ}$ da Constituição trata do princípio da igualdade, inclusive, atenuando as distinções legislativas entre nacionais brasileiros e estrangeiros. Conforme bem explica André de Carvalho Ramos (2008):

\begin{abstract}
Após 1988, houve várias reformas constitucionais, que buscaram amenizar as diferenças de tratamento normativo entre brasileiros e estrangeiros. De fato, eliminou-se a menção a empresas brasileiras de capital nacional, alterou-se também a exploração de recursos minerais e hidráulicos agora possível também a sociedades organizadas no Brasil e não só brasileiros como antes, levantou-se a reserva a brasileiros no setor de navegação (emenda $n^{\circ} 7$ ), além de ter-se permitido a concessão de serviços públicos de relevo a particulares mesmo que estrangeiros e não somente a empresas sob controle acionário estatal ${ }^{182}$.
\end{abstract}

Ainda, Eduardo Teixeira Silveira (2002) argumenta que eventuais distinções entre capital nacional e estrangeiro não seriam tidas como discriminatórias, haja vista o maior poder econômico das empresas estrangeiras ${ }^{183}$. Ademais, a redação do próprio art. $2^{\circ}$, ao

${ }^{180}$ FADDA, Fernanda. Regime constitucional e legal dos investimentos estrangeiro no Brasil. In: RIBEIRO, Marilda Rosado de Sá (Org.) Direito Internacional dos Investimentos. Rio de Janeiro: Renovar, p. 395423, 2014. p. 417.

${ }^{181}$ BRASIL. Lei $\mathrm{n}^{\circ} 4.131$ de 1962. Disciplina a aplicação do capital estrangeiro e as remessas de valores para o exterior e dá outras providências. Diário Oficial [da] República Federativa do Brasil, Brasília, 27 set. 1962.p. 10075, art. 2. ${ }^{\circ}$

${ }^{182}$ CARVALHO RAMOS, André de. Direito dos estrangeiros no Brasil: a imigração, direito de ingresso e os direitos dos estrangeiros em situação irregular. In: SARMENTO, Daniel; IKAWA, Daniela; PIOVESAN, Flávia. Igualdade, Diferença e Direitos Humanos. Rio de Janeiro: Lumen Juris, p.721-745, 2008. p. 731.

${ }^{183} \mathrm{O}$ autor defende que "sustentar uma igualdade a todo preço entre o investimento nacional e o estrangeiro, data vênia, é já tomar uma posição em favor deste". SILVEIRA, Eduardo Teixeira. A disciplina jurídica do investimento estrangeiro no Brasil e no direito internacional. São Paulo: Editora Juarez de Oliveira, 2002. p. 70-71. 
prever a vedação de quaisquer discriminações não previstas em lei, como assevera o autor, faz com que tal princípio somente possa admitir exceções expressamente previstas na mesma lei que o garante, como é o caso do art. 39 da lei, que permite a concessão de crédito pelo Tesouro Nacional e pelas entidades oficiais de crédito público da União e dos Estados $^{184}$.

Entretanto, essa posição gera discordâncias. Isso ocorre, pois, nesse caso, o legislador estaria vedando sua própria competência de legislar em momento futuro. Isto, por sua vez, somente poderia ser efetuado pelo texto Constitucional. Entretanto, como foi na lei ordinária o estabelecido, pode advir uma nova lei que estabeleça que não há mais o direito de tratamento nacional. Assim, segundo Fernanda Fadda, "parece claro, no entanto, que a vedação a discriminações não previstas na lei se dirige apenas às normas infra legais, uma vez que o legislador ordinário não pode opor restrições ao poder de legislar do legislador ordinário futuro" ${ }^{\text {185. }}$.

Desse modo, apesar da existência da exceção do art. 39, a posição que se adota é que mesmo que sobrevenha legislação ordinária que imponha distinção ao tratamento nacional, esta não é incompatível com a lei anterior, de acordo com a boa técnica legislativa, haja vista que o legislador não pode vedar poder legislativo futuro. Com efeito, mesmo nos ordenamentos jurídicos de tradição anglo-americana o respeito pelos precedentes não transborda para o campo das normas legais, para as quais, como no Brasil, aplica-se o critério da lei posterior prevalecente sobre a anterior. Talvez apenas à exceção dos sistemas jurídicos apoiados na religião e, portanto, presos a textos sagrados, é normal o afastamento de regras e princípios para que venham a florescer outros, novos.

Nesse ínterim, segundo Ely Caetano Xavier Júnior (2014), algumas restrições setoriais encontram-se previstas nas normas legais e infra legais, paralelamente àquelas previstas na Constituição. Dentre essas, apenas à título ilustrativo, sem a intenção de se exaurir todas elas, depara-se, por exemplo, com aquelas referentes a: (i) Setor de

${ }^{184}$ Segundo o art. 39: "Art. 39. As entidades, estabelecimentos de crédito, a que se refere o artigo 37, só poderão conceder empréstimos, créditos ou financiamentos para novas inversões a serem realizadas no ativo fixo de empresa cuja maioria de capital, com direito a voto, pertença a pessoas não residentes no País, quando elas estiverem aplicadas em setores de atividades e regiões econômicas de alto interesse nacional, definidos e enumerados em decreto do Poder Executivo, mediante audiência do Conselho Nacional de Economia”. BRASIL. Lei n 4.131 de 1962. Disciplina a aplicação do capital estrangeiro e as remessas de valores para o exterior e dá outras providências. Diário Oficial [da] República Federativa do Brasil, Brasília, 27 de setembro de 1962. p. 10075, art. 39.

${ }^{185}$ FADDA, Fernanda. Regime constitucional e legal dos investimentos estrangeiro no Brasil. In: RIBEIRO, Marilda Rosado de Sá (Org.) Direito Internacional dos Investimentos. Rio de Janeiro: Renovar, p. 395423, 2014. p. 412. 
Transporte Aéreo - restrição à exploração mediante concessão à pessoa jurídica brasileira com pelo menos $4 / 5$ do capital votante e pertencente a brasileiros com direção exclusiva a brasileiros (Lei $n^{\circ}$ 7.565/86, art. 181); (ii) Setor de Transporte Marítimo - restrição do registro em nome do estrangeiro, habilitando apenas as embarcações classificadas na atividade de esporte ou recreio (Lei $n^{\circ} 7.652 / 88$, art. $8^{\circ}$ ) e (iii) Propriedade Imobiliária em Zona de Fronteira - restrição de domínio, posse, titularidade de direito real e participação a qualquer título de estrangeiros sobre imóvel rural em zona de fronteira (Lei $n^{\circ}$ 6.634/79, art. $\left.2^{\circ}\right)^{186}$.

Assim sendo, tem-se que o respaldo jurídico do princípio da igualdade de tratamento entre capital estrangeiro e nacional localiza-se no art. $2^{\circ}$, da Lei $n^{\circ} 4.131 / 62$, porém, a lei ordinária pode prever exceções a empresas brasileiras controladas por estrangeiros não residentes, o que não se torna incompatível com a referida lei, nem com o disposto na Constituição Federal ${ }^{187}$.

d) Remessa de Lucros e Repatriação de Capitais

Na redação original da Lei $n^{\circ} 4.131 / 62$ estipulava-se que somente seria autorizada a repatriação do investimento estrangeiro na proporção máxima de $20 \%$ do capital registrado, logo, calcula-se que esta demoraria no mínimo cinco anos para que fosse completada. Ocorre que este artigo foi revogado pela Lei $n^{\circ} 4.390 / 64$, que insculpiu o direito ilimitado para o repatriamento de capital, diretriz que vigora até os dias de hoje ${ }^{188}$.

Apesar disso, foi estabelecido o imposto suplementar de renda, medida considerada como inibidora desse retorno de capital, haja vista que era instituído "um ônus crescente para as remessas de lucros superiores a $12 \%$ do investimento estrangeiro registrado no triênio anterior. O imposto suplementar de renda possuía alíquotas variáveis que podiam chegar a $60 \%$ do montante a ser remetido ou repatriado" ${ }^{189}$. Entretanto, com o

\footnotetext{
${ }^{186}$ XAVIER JÚNIOR, Ely Caetano. op. cit. p. 162-163. TIBÚRCIO, Carmen. Arbitragem de investimento no Brasil In: RIBEIRO, Marilda Rosado de Sá (Org.). Direito Internacional dos Investimentos. Rio de Janeiro: Renovar, 2014. p. 233-270. p. 236.

${ }^{187}$ FADDA, Fernanda. Regime constitucional e legal dos investimentos estrangeiro no Brasil. In: RIBEIRO, Marilda Rosado de Sá (Org.) Direito Internacional dos Investimentos. Rio de Janeiro: Renovar, p. $395-$ 423, 2014. p. 413.

${ }^{188}$ SILVEIRA, Eduardo Teixeira. A disciplina jurídica do investimento estrangeiro no Brasil e no direito internacional. São Paulo: Editora Juarez de Oliveira, 2002. p.1 33.

${ }^{189}$ XAVIER JÚNIOR, Ely Caetano. op. cit. p. 162-163.
} 
advento da Lei $\mathrm{n}^{\circ} 8.383 / 91$, o imposto suplementar teve sua exigibilidade suspensa, ainda que não tenha sido revogado.

No entanto, esta liberdade da remessa de lucros e da repatriação de capitais possui limitação na hipótese de grave desequilíbrio na balança de pagamentos, sendo, assim, autorizada a proibição da livre transferência da remessa de lucros, por tempo determinado, até que a situação se normalize.

\subsubsection{Perfil das Empresas Brasileiras no Exterior}

Após abordados os fluxos de investimentos estrangeiros diretos ingressantes no Brasil, bem como das fontes normativas internas que regulam a entrada de capital em território nacional e suas nuances, destaca-se que este quadro já não mais se trata da única possibilidade enfrentada pelo Brasil.

Desde meados dos anos 2000, o Brasil tem se deparado com o aumento de empresas nacionais que se lançam ao exterior na busca de internacionalização ${ }^{190}$. Apesar de haver ainda um pequeno número de grandes empresas brasileiras expandindo internacionalmente, o estoque de investimento direto dessas multinacionais multiplicou-se enormemente no limite temporal de pouco mais de uma década ${ }^{191}$. Segundo dados do BCB, em 2001, o estoque de investimento direto de empresas brasileiras no exterior foi de US\$ 49,689 bilhões, já em 2013, alcançou o montante de US\$295,4 bilhões. A evolução de IEDs brasileiros no exterior acelerou-se principalmente de 2005 a 2010, aumentando $138 \%$ no período ${ }^{192}$. Esses dados podem ser visualizados na tabela abaixo:

${ }^{190}$ CYRINO, Álvaro Bruno, OLIVEIRA JÚNIOR, Moacir de Miranda; BARCELlOS, Erika Penido. Evidências sobre a internacionalização de empresas brasileiras. In: OLIVEIRA JÚNIOR, Moacir de Miranda (Org.). Multinacionais brasileiras: internacionalização, inovação e estratégia global. Porto Alegre: Bookman, 2010. p. 93-109. p. 94.

${ }^{191}$ Apesar de o Brasil não contar com uma política de apoio à internacionalização de suas empresas através de IEDs, existem iniciativas positivas como o apoio do Banco Nacional para o Desenvolvimento Econômico e Social (BNDES) no financiamento dessas empresas.

192 CONFEDERAÇÃO NACIONAL DA INDÚSTRIA. Os investimentos brasileiros no exterior - 2014: O desempenho exportador das empresas multinacionais brasileiras. Brasília, 2015. p. 24. 
Tabela 1 - Estoque de Investimentos Diretos do Brasil no Exterior em bilhões (20012013)

\begin{tabular}{|c|c|c|c|}
\hline Ano & $\begin{array}{c}\text { Investimento } \\
\text { Brasileiro } \\
\text { Direto no } \\
\text { Exterior }\end{array}$ & $\begin{array}{c}\text { Participação } \\
\text { no Capital }\end{array}$ & $\begin{array}{c}\text { Empréstimos } \\
\text { Intercompanhias }\end{array}$ \\
\hline $\mathbf{2 0 0 1}$ & 49,689 & 42,584 & 7,104 \\
\hline $\mathbf{2 0 0 2}$ & 54,423 & 43,397 & 11,026 \\
\hline $\mathbf{2 0 0 3}$ & 54,892 & 44,769 & 10,123 \\
\hline $\mathbf{2 0 0 4}$ & 69,196 & 54,027 & 15,169 \\
\hline $\mathbf{2 0 0 5}$ & 79,259 & 65,418 & 13,842 \\
\hline $\mathbf{2 0 0 6}$ & 114,175 & 97,715 & 16,460 \\
\hline $\mathbf{2 0 0 7}$ & 140,036 & 111,339 & 28,697 \\
\hline $\mathbf{2 0 0 8}$ & 155,942 & 113,755 & 42,187 \\
\hline $\mathbf{2 0 0 9}$ & 164,523 & 132,413 & 32,110 \\
\hline $\mathbf{2 0 1 0}$ & 188,637 & 169,066 & 19,572 \\
\hline $\mathbf{2 0 1 1}$ & 202,586 & 192,933 & 9,654 \\
\hline $\mathbf{2 0 1 2}$ & 266,252 & 247,172 & 19,080 \\
\hline $\mathbf{2 0 1 3}$ & 295,382 & 272,921 & 22,461 \\
\hline
\end{tabular}

Fonte: $\mathrm{CNI}^{193}$

Algumas dessas empresas já figuram entre as 100 maiores transnacionais não financeiras dos países em desenvolvimento e em transição, com 3 multinacionais brasileiras presentes na lista de 2014 e 5 companhias na de $2013^{194}$. Este é o caso da VALE S.A., que se encontra dentre as 15 maiores companhias transnacionais do mundo ranqueadas em 2012, segundo a Conferência das Nações Unidas sobre o Comércio e Desenvolvimento (em inglês, UNCTAD) ${ }^{195}$, e da Petrobrás, que representa uma das

${ }^{193}$ CONFEDERAÇÃO NACIONAL DA INDÚSTRIA. Os investimentos brasileiros no exterior - 2014: O desempenho exportador das empresas multinacionais brasileiras. Brasília, 2015. p. 25.

${ }_{195}^{194}$ Ibid., p. 7.

${ }^{195}$ UNITED NATIONS CONFERENCE ON TRADE AND DEVELOPMENT (UNCTAD). World Investment Report 2014: Investing in the SDGs: an action plan. New York and Genebra: United Nations, 2014, p.21. Disponível em: < http://unctad.org/en/PublicationsLibrary/wir2014_en.pdf >. Acesso em: 26 jun. 2014. 
maiores empresas transnacionais na área de gás e petróleo controladas pelo Estado advindas de países em desenvolvimento ${ }^{196}$.

Essa decisão de internacionalização produtiva por parte das firmas brasileiras tem sido percebida, segundo a CNI, "como incontornável para enfrentar a concorrência e fortalecer a participação do Brasil na economia mundial”" ${ }^{197}$. Nesse contexto, existem várias motivações que justificam a busca pela internacionalização ${ }^{198}$.

A primeira consiste nas ameaças à expansão das exportações, tanto do lado da oferta quanto da demanda. $\mathrm{Na}$ oferta, destaca-se a falta de competitividade dos bens produzidos pela mesma empresa internamente, que se demonstra a partir do elevado preço de exportação do produto, consequência direta do alto custo direto e indireto na produção, da alta carga tributária nacional e, também, da taxa de câmbio. Na demanda, enaltece-se a vantagem competitiva de se estar presente no mercado-alvo, próximo aos grandes clientes internacionais, com a possibilidade de adaptar os produtos às características da demanda. A segunda trata-se do fortalecimento de posição no mercado brasileiro e mundial, com o acesso a novas tecnologias através da proximidade das fontes tecnológicas do setor (disponibilidade de tecnologia industrial e interação com concorrentes e a demanda) e a redução da dependência do mercado doméstico de matérias-primas, alcançando custos de produção mais favoráveis. A terceira, diz respeito às vantagens competitivas, muitas delas atribuídas pelas políticas de exportação dos países em que se instalam. Há casos, ainda, em que a atividade da planta industrial no exterior viabiliza a exportação de produtos da matriz brasileira quando, por exemplo, utiliza-se no processo produtivo partes e componentes

196 UNITED NATIONS CONFERENCE ON TRADE AND DEVELOPMENT (UNCTAD). World Investment Report 2014: Investing in the SDGs: an action plan. New York and Genebra: United Nations, 2014, p.21. Disponível em: <http://unctad.org/en/PublicationsLibrary/wir2014_en.pdf $>$. Acesso em: 26 jun. 2014.

${ }^{197}$ CONFEDERAÇÃO NACIONAL DA INDÚSTRIA. Os investimentos brasileiros no exterior - 2014: O desempenho exportador das empresas multinacionais brasileiras. Brasília, 2015. p. 5.

${ }^{198}$ Este lançamento das empresas brasileiras ao exterior deriva de mudanças ocorridas em sua estrutura industrial, à época em que tiveram de enfrentar termos complexos para permanecerem ativas, como a transição de um longo período protecionista para abertura comercial no início dos anos 1990, descontroles macroeconômicos e tensões políticas do governo Collor de Mello. Na prática, como assinalam Coutinho, Hiratuka e Sabatini "a necessidade de se adaptar a essas conjunturas mutantes, instáveis e frequentemente abrasivas fez com que as empresas brasileiras desenvolvessem uma especial capacidade de sobrevivência", o que foi fundamental para que resistissem mais capitalizadas e pudessem concorrer internacionalmente no futuro. Cf. COUTINHO, Luciano; HIRATUKA, Celio; SABATINI, Rodrigo. O investimento direto no exterior como alavanca dinamizadora da economia brasileira. In: BARROS, Octavio de; GIAMBIAGI, Fábio (Org.) Brasil globalizado. Rio de Janeiro: Campus, 2008. p. 74 apud FLEURY, Afonso, FLEURY, Maria Tereza Leme. Multinacionais brasileiras: competências para a internacionalização Rio de Janeiro: FGV, 2012. p.176-177. Cf. FLEURY; FLEURY, 2012, p. 198. 
brasileiros e, a simples atuação dessa unidade produtiva no país em que se instala favorece também a exportação pela matriz de produtos que não são produzidos nesse território ${ }^{199}$.

No que tange à quantidade de companhias brasileiras que se internacionalizam, conforme dados do Banco Central, o número de investidores brasileiros no exterior em 2007 era de 4.774, já em 2011, esse número se elevou para 6.878 e, em 2013, alcançou o patamar de 9.751. Ressalta-se que o estoque de investimentos brasileiros no exterior ainda é concentrado em poucos setores ${ }^{200}$, sendo a grande maioria concentrada no setor de serviços, (94,2\% em 2013), seguida pela indústria de transformação (3,9\% em 2013). Há pouca participação dos setores de agricultura, pecuária e serviços relacionados $(1,5 \%)$ e da indústria extrativista e atividades de apoio (0,4\% em 2013), porém, estas são bem reduzidas $^{201}$.

Segundo relatório anual realizado pela Fundação Dom Cabral, intitulado Ranking FDC das Multinacionais Brasileiras 2015, 48 multinacionais brasileiras representam as entidades privadas nacionais mais relevantes no exterior ${ }^{202}$. Dentre elas, as dez primeiras empresas brasileiras mais internacionalizadas em 2015 foram:

${ }^{199}$ BENTO, Lucas. Time to join the "BIT club"? promoting and protecting Brazilian investments abroad. The American Review of International Arbitration, v. 24, n. 2, p.270-324, 2013. p. 310. Segundo a CNI: "A vantagem competitiva resultante da presença no mercado-alvo é, na verdade, o ator mais relevante do lado da demanda, para induzir o investimento em unidades produtivas no exterior. Destaquese aqui a oportunidade de estar próximo dos seus grandes clientes multinacionais nos mercados em que atuam e o maior conhecimento do Mercado e possibilidade de adaptar seus produtos Às características da demanda". CONFEDERAÇÃO NACIONAL DA INDÚSTRIA. Os investimentos brasileiros no exterior - 2014: O desempenho exportador das empresas multinacionais brasileiras. Brasília, 2015. p.1011. RONCOLATTO, Eduardo Lameirão. Investimentos brasileiros diretos no exterior: regime jurídico e perspectivas. 2008. 196 f. Tese (Doutorado em Direito) - Faculdade de Direito da USP, Universidade de São Paulo, 2008. p. 17.

${ }^{200}$ Segundo pesquisa da Confederação Nacional da Indústria: “Além disso, em macro setores compostos por um número significativo de setores, como serviços e indústria de transformação, não se percebe nenhuma tendência relevante no sentido de uma diversificação setorial do estoque de investimentos". CONFEDERAÇÃO NACIONAL DA INDÚSTRIA. Relatório dos investimentos brasileiros no exterior 2013: recomendações de políticas públicas par ao Brasil. Brasília: CNI, 2013. p. 31.

${ }^{201}$ CONFEDERAÇÃO NACIONAL DA INDÚSTRIA. Os investimentos brasileiros no exterior - 2014: O desempenho exportador das empresas multinacionais brasileiras. Brasília, 2015. p. 26.

202 As outras multinacionais brasileiras mais internacionalizadas em 2015, por ordem crescente de internacionalização, são: Magnesita, Minerva Foods, Votorantim Industrial, Tupy, Tavex/Santista, WEG, Tigre, VALE, Marcopolo, Embraer, Camil Alimentos, Alpargatas, Vicunha Têxtil, Construtora Andrade Gutierrez, Indústrias Romi, Construtora Camargo Corrêa, Neogrid, Natura, BRF, CI\&Software, ItaúUnibanco, Agrale, Braskem, Petrobrás, Klabin, Bematech, Banco do Brasil, Duratex, Randon Implementos e Participações, Ultrapar/Grupo Ultra, Banco Bradesco, TOTVS, Instituto Aquila de Gestão, BRQ IT Services, Eliane, MC, Porto Seguro, CEMIG. 


\section{Tabela 2 - Multinacionais Brasileiras no Exterior}

\begin{tabular}{|l|l|l|}
\hline Posição & \multicolumn{1}{|c|}{ Empresa } & \multicolumn{1}{c|}{$\begin{array}{c}\text { Índice de } \\
\text { Internacionalização }\end{array}$} \\
\hline $\mathbf{1}$ & Fitesa & 0,720 \\
\hline $\mathbf{2}$ & $\begin{array}{l}\text { Construtora Norberto } \\
\text { Odebrecht }\end{array}$ & 0,644 \\
\hline $\mathbf{3}$ & InterCement & 0,573 \\
\hline $\mathbf{4}$ & Gerdau & 0,560 \\
\hline $\mathbf{5}$ & Stefanini & 0,559 \\
\hline $\mathbf{6}$ & Marfrig & 0,536 \\
\hline $\mathbf{7}$ & Artecola & 0,521 \\
\hline $\mathbf{8}$ & Metalfrio & 0,500 \\
\hline $\mathbf{9}$ & CZM & 0,492 \\
\hline $\mathbf{1 0}$ & JBS & 0,488 \\
\hline
\end{tabular}

Fonte: Fundação Dom Cabral - Ranking FDC das Multinacionais Brasileiras $2015^{203}$

Outro dado importante é que, a partir de 2003, as companhias nacionais também passaram a participar de operações de fusão e aquisição envolvendo altos valores de mercado $^{204}$. É o caso da fusão entre a brasileira AMBEV e a belga InterBrew e da compra da canadense Inco pela Companhia Vale do Rio Doce. Além disso, segundo Ana Além e Carlos Cavalcanti, em setembro de 2005, o BNDES aprovou a primeira operação de financiamento na esfera de sua linha de internacionalização, em que a Friboi (maior

${ }^{203}$ FUNDAÇÃO DOM CABRAL. Ranking FDC das multinacionais brasileiras 2015: a capacidade de adaptação cultural das empresas brasileiras no mundo. Disponível em: $<$ http://www.fdc.org.br/blogespacodialogo/Documents/2015/ranking_fdc_multinacionais_brasileiras2015 .pdf>. Acesso em: 29 set. 2015.

${ }^{204}$ CORREAA, Daniela; LIMA, Gilberto Tadeu. O comportamento recente do investimento direto brasileiro no exterior em perspectiva. Revista de Economia Política, São Paulo, v. 28, n. 2, p. 249-268, 2008. p. 250. ALÉM, Ana Cláudia; CAVALCANTI, Carlos Eduardo. O BNDES e o apoio à internacionalização das empresas brasileiras: algumas reflexões. Revista do BNDES, v. 12, n. 24, p.66-89, dez. 2005.p. 71. WILLIAMSON, Peter J., RAMAMURTI, Ravi, FLEURY, Afonso; FLEURY, Maria Tereza Leme. The competitive advantage of emerging Market multinationals. Cambridge: Cambridge University Press, 2013. p. 103. 
empresa frigorífica do país) recebeu US\$ 80 milhões do Banco para a compra de 85,3\% da argentina Swift Armour S.A., tendo sido o valor total da operação estimado em US\$ 200 milhões ${ }^{205}$.

Sobre o destino dos investimentos brasileiros e sua distribuição geográfica, notase que nos dados do BCB de capitais brasileiros no exterior há "discrepância entre, de um lado, os destinos dos fluxos financeiros para aporte de capital o exterior (na saída do Brasil), e de outro, o destino final do investimento"206, que é onde o fluxo se transforma em ativos direta ou indiretamente relacionados às atividades produtivas da entidade privada investidora.

O estoque de investimentos em paraísos fiscais e países-SPEs ${ }^{207}$ são maximizados quando se pretende identificar o destino final dos investimentos ${ }^{208}$. É o caso, por exemplo, de remessas de capital para uma holding ou um veículo financeiro em paraíso físcal, posteriormente transferida a outro Estado para compra de uma unidade produtiva, que é registrada pelo Banco Central como investimento em serviços financeiros ou prestados à companhia, tendo o referido paraíso fiscal como destino geográfico ${ }^{209}$. Por isso, aduz-se que os dados relativos ao destino final dos capitais exportados são incompletos e o seu duplo viés ocorre em função de esses dados referirem-se ao setor e ao destino geográfico da empresa investida de imediato e não da empresa que será a beneficiária última do investimento ${ }^{210}$.

Segundo o BCB, apesar da queda de participação dos paraísos físcais nos IEDs brasileiros esta ainda é elevada, cerca de um terço do total dos investimentos. Ademais, a compensação a esse fenômeno vem do aumento de países europeus como hospedeiros de SPEs no estoque total de investimentos brasileiros no exterior. Em 2013, os primeiros postos foram ocupados por: (i) Áustria (US\$66,5 bilhões, 52 investidores); (ii) Ilhas

${ }^{205}$ O grupo JBS também adquiriu a Pilgrim's Pride, em 2007, empresa norte-americana, tornando-se a maior produtora de carne do mundo.

${ }^{206}$ CONFEDERAÇÃO NACIONAL DA INDÚSTRIA. Os investimentos brasileiros no exterior - 2014: O desempenho exportador das empresas multinacionais brasileiras. Brasília, 2015. p. 37.

${ }^{207}$ Em inglês, Special Purpose Entities.

${ }^{208}$ Por países SPEs entende-se Special Purpose Entities ou Entidades de Propósito Especial.

${ }^{209}$ Segundo a CNI: "Esta questão é relevante devido ao peso que os fluxos de saída de capitais por mecanismos de financiamento offshore, como os centros financeiros offshore ou "paraísos fiscais" e as entidades de propósito especial (special purpose entities - SPEs), têm no movimento internacional de investimentos. Ambos os mecanismos canalizam fluxos financeiros destinados a investimentos e os redirecionam a terceiros países". op. cit., p. 38.

${ }^{210}$ VEIGA, Pedro da Motta; RIOS, Sandra Polónia. Os investimentos brasileiros no exterior: características, motivações e agenda de políticas. Revista Brasileira de Comércio Exterior, Rio de Janeiro,ano $28, \mathrm{n}$. 118, p.66-89, jan./mar. 2014. p. 78. 
Cayman (US\$42,3 bilhões, 989 investidores) e (iii) Países Baixos (US\$30,7 bilhões, 259 investidores) que, juntos, somam 51,1\% do total de IEDs $^{211}$.

Noutro giro, em pesquisa realizada pela Fundação Dom Cabral, de 2015, relacionou-se os países nos quais as empresas brasileiras estão mais presentes, seja por meio de unidades próprias, seja através de franquias, o que nos faz identificar a dimensão da presença brasileira também por este critério. Veja-se:

\section{Tabela 3 - Países com Maior Presença de Empresas Brasileiras - 2015}

\begin{tabular}{|l|l|l|}
\hline Posição & País & $\begin{array}{l}\text { Número de } \\
\text { Empresas }\end{array}$ \\
\hline $\mathbf{1}$ & EUA & 39 \\
\hline $\mathbf{2}$ & Argentina & 34 \\
\hline $\mathbf{3}$ & México & 26 \\
\hline $\mathbf{4}$ & Colômbia & 25 \\
\hline $\mathbf{5}$ & Chile & 24 \\
\hline $\mathbf{6}$ & China & 22 \\
\hline $\mathbf{6}$ & Peru & 22 \\
\hline $\mathbf{6}$ & Uruguai & 22 \\
\hline $\mathbf{7}$ & Paraguai & 17 \\
\hline $\mathbf{8}$ & Portugal & 15 \\
\hline $\mathbf{9}$ & Bolívia & 13 \\
\hline $\mathbf{9}$ & Venezuela & 13 \\
\hline $\mathbf{1 0}$ & Alemanha & 12 \\
\hline $\mathbf{1 0}$ & Angola & 12 \\
\hline $\mathbf{1 0}$ & Espanha & 12 \\
\hline $\mathbf{1 0}$ & França & 12 \\
\hline $\mathbf{1 0}$ & Itália & 12 \\
\hline $\mathbf{1 0}$ & Reino Unido & 12 \\
\hline $\mathbf{F}$ & & \\
\hline
\end{tabular}

Fonte: Fundação Dom Cabral,2015 212

Ressalta-se que os investimentos brasileiros na América Latina, apesar de terem caído em 2013, permanecendo no patamar de 7\%, (em especial na Argentina), enquanto em 2001, essa porcentagem era de 13,7\% no estoque, conforme pesquisa de 2015 realizada pela CNI, "o continente ainda é o principal receptor de investimentos estrangeiros diretos

211 BRASIL. Banco Central do Brasil. Capitais Brasileiros no Exterior (CBE) - Ano-Base 2013. Disponível em:< http://www4.bcb.gov.br/rex/CBE/Port/ResultadoCBE2013p.pdf $>$. Acesso em: 15 out. 2015.

${ }^{212}$ FUNDAÇÃO DOM CABRAL. Ranking FDC das multinacionais brasileiras 2015: a capacidade de adaptação cultural das empresas brasileiras no mundo, p. 51. Disponível em: $<$ http://www.fdc.org.br/blogespacodialogo/Documents/2015/ranking_fdc_multinacionais_brasileiras2015 .pdf>. Acesso em: 29 set. 2015. 
de empresas brasileiras, com $45 \%$ do total das empresas pesquisadas" ${ }^{213}$.Verifica-se um crescimento na participação em República Dominicana, Peru, Chile, México e Colômbia ${ }^{214}$.

Ademais, aduz-se que os investimentos brasileiros no exterior não se concentram apenas na América Latina. O que se nota é uma diversificação de destinos, em 2015, para América do Norte (que ficou em segundo lugar, com 8,8\%), Ásia e África (com 11,8\%, que empatam como os terceiros outros maiores destinos) ${ }^{215}$.

Nesse diapasão, salienta-se que os investimentos brasileiros no continente africano são representados por várias empresas, como, por exemplo, pela Petrobrás ${ }^{216} \mathrm{e}$ pela Odebrecht ${ }^{217}$ (em particular em Angola). Esta última, acrescida também de outras companhias do gênero como Camargo Corrêa e Andrade Gutierrez, por exemplo, representam a participação das firmas brasileiras de engenharia, que se voltam "para o desenvolvimento de grandes projetos de infraestrutura, principalmente em países africanos

213 CONFEDERAÇÃO NACIONAL DA INDÚSTRIA. Relatório dos investimentos brasileiros no exterior 2013: recomendações de políticas públicas par ao Brasil. Brasília: CNI, 2013; CONFEDERAÇÃO NACIONAL DA INDÚSTRIA. Interesses da indústria na América do Sul: Investimentos. Brasília: CNI, 2015.

${ }^{214}$ CONFEDERAÇÃO NACIONAL DA INDÚSTRIA. Os investimentos brasileiros no exterior - 2014: O desempenho exportador das empresas multinacionais brasileiras. Brasília, 2015. p. 38-41.

${ }^{215}$ FUNDAÇÃO DOM CABRAL. Ranking FDC das multinacionais brasileiras 2015: a capacidade de adaptação cultural das empresas brasileiras no mundo. Disponível em: $<$ http://www.fdc.org.br/blogespacodialogo/Documents/2015/ranking_fdc_multinacionais_brasileiras2015 .pdf>. Acesso em: 29 set. 2015. FLEURY, Afonso, FLEURY, Maria Tereza Leme. Multinacionais brasileiras: competências para a internacionalização. Rio de Janeiro: FGV, 2012. p. 194-196.

${ }^{216}$ A Petrobrás apresentava-se de forma limitada em Angola até 2006, atuando apenas como sócia de dois blocos, sem operar em trabalhos de prospecção. A partir de 2006, a empresa passou a conquistar direitos de exploração e produção em mais quatro blocos, sendo operadora em três deles. VILLAS-BÔAS, Júlia Covre. Os investimentos brasileiros na África no governo Lula: um mapa. Meridiano 47, v. 12, n. 128, p.3-9, /2011. INGLESIAS, Roberto; COSTA, Katarina. O investimento direto brasileiro na África: características, condicionantes e perspectivas. Pontes, v. 8, n. 2, 2012. Disponível em: $<$ http://www.ictsd.org/bridges-news/pontes/news/o-investimento-direto-brasileiro-na-\%C3\%A1 fricacaracter\%C3\%ADsticas-condicionantes-e>. Acesso em: 6 out. 2015.

${ }^{217}$ A Odebrecht iniciou seus empreendimentos em Angola durante a construção da hidrelétrica de Capanda, em 1984. Hodiernamente, atua em Angola na construção da Hidrelétrica de Laúca, a maior da África, com 2.057 MW de potência, além dos trabalhos civis e eletromecânicos na Hidrelétrica de Cambambe; na terraplanagem da Refinaria de Lobito; e nas obras do Aeroporto de Namibe, da Rodovia de BenguelaBaía e do Edifício Belas Business IV. Em Moçambique, a empresa possui aliança com a VALE na expansão das instalações industriais da mina de carvão de Moatize. Em Gana, a empresa efetua as obras do Corredor Rodoviário Oriental. Cf. ODEBRECHT. Odebrecht Infraestrutura - África, Emirados Árabes e Portugal. Disponível em: <http://odebrecht.com/pt-br/negocios/nossos-negocios/infraestrutura-africaemirados-arabes-e-portugal>. Acesso em: 6 out. 2015. 
de língua portuguesa" ${ }^{218}$, e pela Vale (principalmente em Zâmbia, Moçambique e Malaui $^{219}$ ), na exploração de recursos minerais de carvão.

Essa afirmação coaduna-se com a estatística levantada pelo World Investment Report 2013, de que as empresas multinacionais dos BRICS se tornaram muito ativas no continente africano ${ }^{220}$, o que inclui não apenas firmas chinesas, indianas, sul-africanas e russas, mas também brasileiras, já que, em 2012, quatro novos países africanos entraram para a relação de nações que contam com a presença de transnacionais brasileiras, quais sejam Cabo Verde, Gana, Marrocos e Tunísia. Portanto, nota-se que o Estado brasileiro enfrenta atualmente uma transição, saindo da qualidade de exclusivo receptor de investimentos, passando para também investidor, em razão do processo de internacionalização de suas empresas nacionais.

Entretanto, nem sempre os investimentos brasileiros são bem recebidos no exterior. Foi o que ocorreu mais recentemente, por exemplo, com a nacionalização dos ativos da Petrobrás na Bolívia em 2006. A Petrobrás, em sua nova estratégia de internacionalização, realizou investimentos no país por intermédio da Petrobrás International Braspetro $B V$, uma subsidiária constituída sob as leis holandesas e com sede nesse país, e que, portanto, é considerada nativa da Holanda. Com tal estrutura, como bem ressalta Marilda Rosado de Sá Ribeiro, os investimentos realizados pela Petrobrás em nações em desenvolvimento, como Bolívia, Moçambique, Colômbia, Angola, Líbia,

${ }^{218}$ FLEURY, Afonso; FLEURY, Maria Tereza Leme. Multinacionais brasileiras: competências para a internacionalização. Rio de Janeiro: FGV, 2012. p. 198.

${ }^{219}$ Desde 2004 a VALE está presente em Moçambique e detém a concessão de uma das maiores reservas de carvão do mundo em Moatize, na província de Tete (noroeste do país), as quais possuem uma capacidade operacional de 11 milhões de toneladas de carvão. Suas vendas são voltadas para os principais mercados transoceânicos, como Ásia Oriental, Américas, Europa e Índia e saem de Moçambique através do Porto de Beira, em que a VALE possui a concessão do Terminal Cais 8, com capacidade de escoamento de 6 milhões de toneladas de carvão por ano. No Malaui, a VALE espera investir US\$ 4,4 bilhões na extensão do Corredor de Desenvolvimento Nacala, projeto ferroviário que cruza os territórios do Maláui e Moçambique, e que ligará a Mina de Carvão de Moatize à Baía de Nacala, onde será construído um porto marítimo de águas profundas. Assim, a empresa poderá contar com uma infraestrutura de logística que sustente suas operações na África Central e Oriental. Estima-se que pela ferrovia deverão ser transportadas 18 milhões de toneladas de carvão por ano. Segundo a própria empresa, os benefícios dessa plataforma vão beneficiar não só Moçambique e Malauí, mas também os países vizinhos. Cf. VALE. Vale no mundo. Disponível em: <http://www.vale.com/mozambique/PT/aboutvale/acrossworld/Paginas/default.aspx $>$. Acesso em: 6 out. 2015. BRASIL. Ministério do Desenvolvimento, Indústria e Comércio. Brasil e Maláui assinam acordo de cooperação e facilitação de investimentos, 25 jun. $2015 . \quad$ Disponível em: $<$ http://www.desenvolvimento.gov.br/portalmdic/sitio/interna/noticia.php?area=1\&noticia=13872>. Acesso em: 30 jun. 2015.

${ }^{220}$ UNITED NATIONS CONFERENCE ON TRADE AND DEVELOPMENT. World Investment Report 2013: Global value chains: investment and trade for development. New York; Genebra: United Nations, 2013. p. xiii. Disponível em: < http://unctad.org/en/PublicationsLibrary/wir2014_en.pdf>. Acesso em: 30 jun. 2014. 
México e Nigéria devem ser considerados investimentos holandeses (mesmo o Brasil sendo o controlador final desta companhia) e não genuinamente brasileiros. Sua proteção jurídica internacional reside, portanto nos tratados bilaterais de investimento assinados pela Holanda $^{221}$. Não obstante, cabe lembrar que, conforme critérios comuns nos TBIs, provavelmente seriam também brasileiros em razão dos ativos existentes.

Frente à ação de nacionalização da subsidiária da Petrobrás pelo governo da Bolívia, chamou atenção o fato de que o respaldo jurídico caso a situação fosse encaminhada para a arbitragem mista seria o TBI Holanda-Bolívia, haja vista que a proteção jurídica internacional por meio dos TBIs é atribuída conforme o critério de nacionalidade do país de constituição da empresa ou de sua sede. Entretanto, Jean Kalicki e Suzana Medeiros aduzem que esta prática de acionamento por meio de um TBI de terceiros, embora legítima, pode também dar chance para as partes signatárias poderem denegar benefícios do acordo a investidores que não tenham atividades empresariais substantivas em seu "país de origem putativo" ("putative home country")222.

Em contrapartida, a solução alcançada se deu por meio da diplomacia. No dia 10 de maio de 2007, o governo brasileiro anunciou a celebração de acordo entre a Petrobrás e o Estado Plurinacional da Bolívia envolvendo a transferência total da propriedade de duas refinarias da Petrobrás Bolivia Refinación $S A(P B R)^{223}$ para o governo boliviano. De acordo com o compromisso estabelecido, a empresa brasileira iria receber US\$ 12 milhões pela venda de seus ativos.

Além desse episódio, outra ameaça que afetou empresas brasileiras na América Latina foi o ocorrido com a Odebrecht. Em 2008, a companhia de engenharia e construção foi forçada a encerrar suas operações no projeto da hidrelétrica de São Francisco, segunda maior do Equador ${ }^{224}$. Houve decreto executivo por parte do governo equatoriano determinando a custódia dos bens das obras da Odebrecht e ocupação militar de

${ }^{221}$ RIBEIRO, Marilda Rosado de Sá. Sovereignty over natural resources investment law and expropriation: the case of Bolivia and Brazil. The Journal of World Energy Law and Business, Oxford Journals. v. 2, n. 2, p. 129-148, July 2009. p. 132.

${ }^{222}$ KALICKI, Jean; MEDEIROS, Suzana. Investment arbitration in Brazil: revisiting brazil's traditional reluctance towards ICSID, BITs and investor-state arbitration. Arbitration International, v. 24, issue 3, p.423-445, 2008. p. 441-442.

223 Responsável pelo refinamento, comercialização e transporte de produtos, subprodutos e outros hidrocarbonetos.

${ }^{224}$ OLIVEIRA, Carina Costa de; MONEBHURRUN, Nitish. As implicações de um investimento no setor hidrelétrico equatoriano tiradas da experiência da Odebrecht. Casoteca Direito GV - Produção de Casos, 2011. Disponível em: $<$ http://direitosp.fgv.br/sites/direitosp.fgv.br/files/odebrecht__narrativa.pdf $>$. Acesso em: 16 set. 2015. 
acampamentos e escritórios da empresa, a rescisão de todos os seus acordos com o Estado equatoriano e a revogação dos vistos de diretores e funcionários da corporação ${ }^{225}$. Ao final, após tentativas diplomáticas de acordo, a companhia brasileira acabou sendo expulsa de forma intransigente pelo Governo do Equador.

Observa-se com essas duas situações que tanto a Petrobrás quanto a Odebrecht tiveram que se sujeitar a vias políticas e diplomáticas para dirimir o sucedido. No entanto, esses meios são marcados por sua lentidão, bem como não necessariamente preveem garantias de compensação para as perdas e os danos sofridos ${ }^{226}$.

Portanto, nota-se que diante da internacionalização das empresas brasileiras, o Brasil vem preocupando-se com a adoção de mecanismos para a proteção dos investimentos de seus nacionais no exterior, haja vista os riscos políticos a serem enfrentados no território estrangeiro. Como se verá mais adiante, para isso se considerou o feedback do setor privado sobre quais são os principais obstáculos enfrentados, para então, eventualmente reposicionar-se no que concerne à regulação internacional dos investimentos estrangeiros.

\subsection{CONSIDERAÇÕES FINAIS}

Desse modo, conclui-se que os APPRIs têm cumprido o papel para o qual foram engendrados, qual seja proteger os investimentos estrangeiros, haja vista que possui estrutura clausular, apesar de não unívoca, básica e que trata de pontos sensíveis ao investidor, mesmo atualmente também atendendo aos propósitos de promoção e facilitação de investimentos.

Ademais, apesar de os países em desenvolvimento terem aderido mais intensamente ao regime da proteção jurídica internacional dos investimentos no final do século XX, em função da corrida em atrair cada vez mais investimentos ao seu território, à época, o Brasil não seguiu esta tendência.

Mesmo assim, o país permaneceu como grande receptor de investimentos estrangeiros, condição que se estende até os dias de hoje. Houve tentativas de adesão a

\footnotetext{
225 ODEBRECHT. Ecuador: Odebrecht clarifies. Disponível em: $<$ http://www.odebrecht.com/en/node/2649>. Acesso em: 1 jul. 2014. BENTO, 2013, p. 316-317.

${ }^{226}$ BENTO, Lucas. Time to join the "BIT club"? promoting and protecting Brazilian investments abroad. The American Review of International Arbitration, New York, v. 24, n. 2, p.270-324, 2013. p. 317.
} 
tratados bilaterais de investimento durante a década de 1990, contudo, a não ratificação destes pelo Congresso Nacional reforçou o temor que se tem acerca de temas como compensação e a ausência da exceção para os títulos da dívida pública, restrição à livre transferência de ativos diante de graves crises econômicas e cambiais e, principalmente, arbitragem de investimentos e sua incompatibilidade com a soberania nacional.

Entretanto, o elemento-chave que tem desencadeado uma mudança de posição do governo brasileiro, como será tratado no próximo capítulo, é o fato de as empresas brasileiras terem se internacionalizado. Apesar de este fenômeno ainda ser baixo se comparado a outros países em desenvolvimento, este já é significativo. Contudo, os investimentos brasileiros no exterior nem sempre foram bem recebidos, como se pode notar nos casos ocorridos na Bolívia e no Equador, o que mobilizou o setor privado, em estudos recentes, a indicar a adesão ao sistema da proteção internacional dos investimentos como um ponto relevante que poderia trazer maior segurança e previsibilidade na operacionalização de suas atividades. Nesse diapasão, destaca-se os esforços do governo brasileiro para a criação de uma nova estrutura regulatória internacional sobre investimentos, já assinada com alguns países e publicada em 2015, pelo que se passa à análise pormenorizada de como se deu sua formulação e, também, de sua estrutura clausular. 


\section{ACORDOS DE COOPERAÇÃO E FACILITAÇÃO DE INVESTIMENTOS (ACFIS)}

Com a expansão de investimentos brasileiros no exterior, o governo brasileiro, após cerca de duas décadas da assinatura dos primeiros tratados não ratificados, tomou a iniciativa de instituir novo acordo de promoção e proteção de investimentos. O Acordo de Cooperação e Facilitação de Investimentos (ACFI) foi desenvolvido de forma cuidadosa, a partir da atuação conjunta do governo brasileiro e da iniciativa privada, maior interessada na concretização desse novo standard de proteção, com vistas a aliar as principais demandas do setor empresarial, bem como a experiência de outros países e organizações internacionais $^{227}$.

Desse modo, o presente capítulo tem como objetivo, em um primeiro momento, apresentar o contexto de surgimento do novo ACFI brasileiro. Feito isso, pretende-se analisar comparativamente, de forma minuciosa, as principais cláusulas materiais dos acordos. Visa-se assim identificar o principal escopo desses instrumentos, e sua linha evolutiva até o momento, com suas principais semelhanças e diferenças.

\subsection{CONTEXTO DE SURGIMENTO}

Apesar de o Brasil ainda ser "um ator bastante secundário entre os emissores de investimentos internacionais, inclusive entre os países em desenvolvimento" ${ }^{228}$, haja vista não ter sido tão ativo em nenhum dos ciclos de investimentos estrangeiros que mobilizaram nações em desenvolvimento nos últimos anos, bem como ter dificuldades para manter o ritmo ascendente de investimentos internacionais, é fato notório que a expansão dos investimentos brasileiros no exterior está acontecendo, mesmo que em ritmo mais lento se comparado a outras economias emergentes de destaque ${ }^{229}$.

Diante disso, o Brasil tem demonstrado mudança de posição quanto à aderência aos padrões jurídicos de promoção e proteção de investimentos estrangeiros. A primeira indicação de mudança se deu no ano de 2010, em que houve discussões para a adoção de

${ }^{227}$ UNITED NATIONS CONFERENCE ON TRADE AND DEVELOPMENT. World Investment Report 2015: Reforming international investment governance. New York; Geneva: United Nations, 2015. p. 108.

${ }^{228}$ CONFEDERAÇÃO NACIONAL DA INDÚSTRIA. Relatório dos investimentos brasileiros no exterior 2013: recomendações de políticas públicas par ao Brasil. Brasília: CNI, 2013. p. 25.

${ }^{229}$ Ibid., p. 25. 
um TBI com o Chile, porém, este não saiu do papel ${ }^{230}$. Mais adiante, em 2011, essa movimentação teve continuidade, pelo que o Canadá demonstrou interesse em assinar acordo de investimentos com o Brasil, entretanto, as negociações ainda não foram iniciadas, tendo o mesmo ocorrido com a União Europeia.

Ao longo dos anos 2000, o Brasil assinou onze memorandos de entendimento considerando a promoção do comércio e investimentos com Chile, Suriname, Nicarágua, Coreia do Sul, Cingapura, Líbia, Uzbequistão, Guiana, África do Sul, Venezuela e Quênia. Eles não contêm disposições relativas aos mecanismos de resolução de controvérsias, exceto no que tange às negociações diplomáticas. No entanto, esses instrumentos representam a disposição do Brasil em promover e proteger seus investimentos com outros países e, em especial entre as nações em desenvolvimento, refletindo a proliferação de investimentos no âmbito das relações Sul-Sul ${ }^{231}$.

Entretanto, apesar das intenções formalizadas anteriormente, foi somente em 2012 que a Câmara de Comércio Exterior $(\mathrm{CAMEX})^{232}$ garantiu um mandato formal ao Grupo Técnico para Estudos Estratégicos em Comércio Internacional (GTEX), que ficou encarregado, dentre outros assuntos, da elaboração de um projeto para a adoção de um novo de acordo de investimentos para o Brasil que atendesse aos interesses brasileiros e se adequasse ao atual cenário econômico internacional ${ }^{233}$.

O GTEX recomendou a criação deste novo arquétipo de tratado, sob a liderança da Secretaria de Comércio Exterior do Ministério do Desenvolvimento, Indústria e

${ }^{230}$ CHILE e Brasil discutem acordos de investimento. Revista Exame, São Paulo. Disponível em: $<$ http://exame.abril.com.br/brasil/noticias/chile-brasil-discutem-acordo-investimentos-589805>. Acesso em: 30 maio 2014.

${ }^{231}$ GARCIA NETO, Paulo Macedo. Investment arbitration in Brasil: the landscape of investment arbitration in Brazil and why Brazil should become a more important player in the investment arbitration arena In: LEVY, Daniel de Andrade; BORJA, Ana Gerdau de; PUCCI, Adriana Noemi. Investment protection in Brazil. Alphen aan den Rijn: Wolters Kluwer, 2013. p. 3-16.

${ }^{232}$ A CAMEX é um órgão integrante do Conselho de Governo da Presidência da República e tem por objetivo a formulação, adoção, implementação e coordenação de políticas e atividades relativas ao comércio exterior de bens e serviços. É composta pelo Ministro de Estado do Desenvolvimento, Indústria e Comércio Exterior, a quem cabe a presidência da CAMEX, e pelos Ministros de Estado Chefe da Casa Civil; das Relações Exteriores; da Fazenda; da Agricultura, Pecuária e Abastecimento; do Planejamento, Orçamento e Gestão; e do Desenvolvimento Agrário. Cf. BRASIL. Ministério do Desenvolvimento, Indústria e Comércio. Câmara de Comércio Exterior - CAMEX. Disponível em: $<$ http://www.desenvolvimento.gov.br/sitio/interna/interna.php?area=1\&menu=1920>. Acesso em: 10 ago. 2015.

${ }^{233}$ MOROSINI, Fábio; BADIN, Michelle Ratton Sanchez. The Brazilian Agreement on Cooperation and Facilitation of Investments (ACFI): A New Formula for International Investment Agreements? Investment Treaty News. Disponível em: <https:/www.iisd.org/itn/2015/08/04/the-brazilian-agreementon-cooperation-and-facilitation-of-investments-acfi-a-new-formula-for-international-investmentagreements/>. Acesso em: 10 ago. 2015. 
Comércio (SECEX), o que deu novo impulso para que o Direito dos Investimentos voltasse à pauta do governo brasileiro. Conforme salientam Fábio Morosini e Michelle Ratton Sanchez Badin, "o mandato do GTEX foi o zênite do processo, e resultado da capacidade técnica dos oficiais do MDIC em um momento político favorável no Brasil"234.

Em razão da expansão de investimentos brasileiros no exterior, fazia-se necessária a iniciativa brasileira de negociar novo acordos de investimento mais alinhado à nova posição brasileira de país exportador de capital. Nos últimos anos, as transnacionais brasileiras têm se distribuído geograficamente nos mais diversos territórios, se concentrando principalmente na América Latina. Entretanto o processo de expansão para o continente africano tem sido significativo e já não mais pode ser ignorado. Destarte, a conscientização veio com a iniciativa brasileira de estabelecer acordos de investimento com países sul-americanos e africanos ${ }^{235}$.

Quanto à África, conforme aduziu o Ministério do Desenvolvimento Indústria e Comércio (MDIC), por meio de seu Secretário-Geral de Comércio Exterior, Daniel Godinho, houve elevação nos fluxos comerciais com o continente, que passou de US\$ 10,431 bilhões, em 2004, para US\$ 28,533 bilhões"236 em $2013^{237}$. Por isso, o governo brasileiro encontra-se estimulado em adotar um APPRI com países africanos tidos como comercialmente relevantes, como Angola, Moçambique, Nigéria e África do Sul. Contudo, segundo relatório da Agência Brasileira de Promoção de Exportações e Investimentos (APEX) "o arranjo institucional corrente nesses países adiciona risco ao investimento,

${ }^{234}$ MOROSINI, Fábio; BADIN, Michelle Ratton Sanchez. The Brazilian Agreement on Cooperation and Facilitation of Investments (ACFI): A New Formula for International Investment Agreements? Investment Treaty News. Disponível em: < https:/www.iisd.org/itn/2015/08/04/the-brazilian-agreementon-cooperation-and-facilitation-of-investments-acfi-a-new-formula-for-international-investmentagreements/>. Acesso em: 10 ago. 2015.

235 BRASIL. Ministério do Desenvolvimento, Indústria e Comércio. Godinho analisa momento de oportunidades no comércio exterior. 25 out. 2013. Disponível em: $<$ http://www.desenvolvimento.gov.br/portalmdic/sitio/interna/noticia.php?area=5\&noticia=12762>. Acesso em 30 mai 2014.

${ }^{236}$ BRASIL. Ministério do Desenvolvimento, Indústria e Comércio Exterior. Governo incentiva investimentos de na Aualidade África. Disponível em: $<$ http://www.desenvolvimento.gov.br/sitio/interna/noticia.php?area=5\&noticia=13202>. Acesso em: 1 jun. 2014.

237 Segundo o World Investment Report 2013, a África já se tornou o principal destino das empresas transnacionais brasileiras, que através de incentivos financeiros proporcionados pelo Banco Nacional de Desenvolvimento Econômico e Social (BNDES), já se expandem pela África Subsaariana. Cf. UNITED NATIONS CONFERENCE ON TRADE AND DEVELOPMENT. World Investment Report 2013: Global value chains: investment and trade for development. New York; Genebra: United Nations, 2013. p. 5. Disponível em: <http://unctad.org/en/PublicationsLibrary/wir2014_en.pdf $>$. Acesso em: 30 jun. 2014. 
fazendo com que o custo aumente consideravelmente e dificulte sobretudo a atuação das pequenas e médias empresas que desejam operar no continente"238.

Logo, aproveitando o mandato de política externa focado nas relações Sul-Sul, o GTEX desenvolveu seus trabalhos com consultas ao setor privado, para que pudesse ter acesso às principais preocupações e desafios enfrentados no processo de transnacionalização. Ao longo das consultas, os investidores brasileiros procuravam transparecer suas verdadeiras preocupações e dificuldades ao investir em território estrangeiro, dentre elas (i) a mitigação de problemas específicos, (ii) a dificuldade de acesso à informação em território estrangeiro, (iii) a necessidade de agendas temáticas e de negócios e (iv) o reforço do diálogo institucional ${ }^{239}$. Conforme ressalta Pedro da Motta Veiga, as empresas brasileiras também enfrentam problemas associados "a procedimentos poucos claros na implementação de regras ou do marco jurídico existente, que poderíamos classificar como risco regulatório" 240 .

Salienta-se que o assunto já vinha sendo discutido pelo setor privado de antemão. Em 2013, em pesquisa realizada com empresas transnacionais brasileiras do setor privado, a Confederação Nacional da Indústria (CNI) identificou, em grau de importância, que a segunda maior recomendação desses atores no que se refere à diplomacia e à política econômica externa do Brasil era a negociação de APPRIs com o intuito de mitigar os crescentes riscos políticos enfrentados em território estrangeiro, sendo que Argentina, China e México constituiriam, na opinião do empresariado, os países prioritários para essa iniciativa. Já ao serem listadas as principais recomendações políticas para apoiar e facilitar os investimentos no exterior de forma geral, a celebração de APPRIs se enquadrou na sétima posição em preferência ${ }^{241}$.

${ }^{238}$ BRASIL. Agência Brasileira de Promoção de Exportações e Investimentos. Boletim de Facilitação de Negócios Análise e estudos de Conjuntura Internacional, ano 2, ed. 3, 2015. Disponível em: $<$ http://arq.apexbrasil.com.br/portal/BoletimNegocios_Edicao03.pdf $>$. Acesso em: 26 out. 2015.

${ }^{239}$ SOUZA, Renato Rezende de Campos. Cooperation and Facilitation Investment Agreement - CFIA. [apresentação de slides no World Investment Forum]. [s.1.], mai 2015. Disponível em: <http://unctadworldinvestmentforum.org/wp-content/uploads/2015/03/Brazil_side-event-Wednesday_modelagreements.pdf $>$. Acesso em: 15 set. 2015.

240 VEIGA, Pedro da Motta. A África na agenda econômica do Brasil. Comércio, investimentos e cooperação. Revista Brasileira de Comércio Exterior. Ano 27, n. 116, jul./set. p. 4-19, , 2013. p. 116. Outras preocupações que se aventam é a falta de mão de obra qualificada e a precariedade dos serviços de energia elétrica, os últimos úteis à produção e à logística.

${ }^{241}$ Esta recomendação somente ficou atrás, em grau de importância, da primeira posição, que se refere à ampliação do apoio diplomático brasileirona defesa dos interesses de empresas investidoras brasileiras junto aos governos dos países de destino dos investimentos. Cf. CONFEDERAÇÃO NACIONAL DA INDÚSTRIA. Relatório dos investimentos brasileiros no exterior 2013: recomendações de políticas públicas par ao Brasil. Brasília: CNI, 2013. p. 61-65. 
Ademais, segundo position paper elaborado pela Federação das Indústrias do Estado de São Paulo (FIESP), a assinatura de ACFIs com parceiros estratégicos, em particular na América Latina e África, trata-se de uma das prioridades endossadas pela FIESP. Conforme posicionamento da instituição, a existência de mecanismos que provenham maior estabilidade, previsibilidade e segurança jurídica para os investimentos estrangeiros diretos brasileiros irá atender adequadamente às expectativas dos investidores quanto à segurança na operacionalização empresarial nos mercados estrangeiros ${ }^{242}$. Assim, verifica-se que estes instrumentos são reconhecidos como uma das prioridades do setor privado, o que justifica o empenho para sua concretização.

Nesse diapasão, em 2013 foi aprovado pela CAMEX o acordo de cooperação e facilitação de investimentos brasileiro. Haja vista que o mesmo já estava engatilhado, este foi proposto aos Estados em que companhias brasileiras possuíam investimentos mais consistentes. Ressalta-se que Moçambique, Angola e México foram os primeiros países a reagirem de forma positiva às negociações empreendidas ${ }^{243}$. Importante destacar que o novo acordo brasileiro de investimentos resulta da elaboração conjunta realizada pelo Itamaraty, MDIC, Secretaria Executiva da CAMEX e Ministério da Fazenda, em consulta com o setor privado, representado pela CNI e pela FIESP ${ }^{244}$.

Desta feita, em conferência oficial proferida no World Economic Forum 2014, o Secretário Daniel Godinho expôs que os três pilares centrais dos ACFIs, que à época já estavam sendo negociados, seriam: (i) atingir governança institucional; (ii) instituir

${ }^{242}$ FEDERAÇÃO DAS IndÚSTRIAS do ESTAdo DE SÃo PAUlO. Position Paper Proposals for the External Integration of Industry - 2014. São Paulo: FIESP, 2014. p. 24.

${ }^{243}$ Diante do avanço, o Ministério do Desenvolvimento, Indústria e Comércio (MDIC) realizou declaração oficial em outubro de 2013 manifestando que o governo brasileiro deu "sinal verde para proposta de acordo de investimentos entre Brasil e países africanos", haja vista que o Conselho de Ministros da CAMEX aprovara ao diretriz de acordo de investimentos a ser adotado pelo Brasil. LEO, Sérgio. Brasil cria modelo de proteção a investidor BRASIL cria modelo de proteção a investidor. Valor Econômico, Brasília, 7 out. 2013. Disponível em: <http://www.valor.com.br/brasil/3295402/brasil-cria-modelo-deprotecao-investidor>. Acesso em: 2 fev. 2014. COMEX DO BRASIL. Brasil apresenta proposta de investimento na África do Sul, Angola, Moçambique e Nigéria. Disponível em: $<$ http://comexdobrasil.com/brasil-apresenta-proposta-de-acordo-de-investimento-na-africa-sul-angolamocambique-nigeria/>. Acesso em: 2 fev. 2014.

244 BRASIL. Ministério das Relações Exteriores. Nota 194 Acordo Brasil-México de Cooperação e Facilitação de Investimentos - Cidade do México, 26 de maio de 2015. Disponível em: $<$ http://www.itamaraty.gov.br/index.php?option=com_content\&view=article\&id=9890:acordo-brasilmexico-de-cooperacao-e-facilitacao-de-investimentos-cidade-do-mexico-26-de-maio-de2015\&catid=42\&Itemid=280\&lang=pt-BR $>$. Acesso em: 30 maio 2015. 
mecanismos para mitigação de riscos e prevenção e solução de disputas e (iii) promover a facilitação de investimentos através agendas temáticas ${ }^{245}$.

Nesse sentido, em uma análise geral, observa-se que os ACFIs foram arquitetados de acordo com a revisão dos tradicionais TBIs brasileiros dos anos 1990 aliadas às principais críticas a esses dispositivos, considerando, sobretudo, os limites da regulação doméstica e as contribuições do setor privado brasileiro, baseado em suas experiências recentes. O resultado dessa combinação foi um acordo focado na facilitação de investimentos no exterior, no propósito da cooperação, na mitigação de riscos e na reafirmação do policy space brasileiro.

\subsection{PREVISÕES MATERIAIS DOS ACFIs}

Até o momento o Brasil assinou os seguintes Acordos de Cooperação e Facilitação de Investimentos: com Moçambique, em 31.03.15; com Angola, em 01.04.15; com México, em 27.05.15; com Malaui, em 25.06.15; e, com Colômbia, em 09.10.15. Há ainda expectativa de assinatura de novos acordos com África do Sul, Argélia, Chile ${ }^{246}$, Marrocos, Peru e Tunísia ${ }^{247}$ e foram iniciadas conversas a respeito com República Dominicana, Nigéria, Cingapura e Vietnã. O novo acordo também foi apresentado em setembro de 2015 para todos os países do Mercado Comum do Sul (MERCOSUL), bloco econômico regional que o Brasil faz parte, juntamente com Argentina, Paraguai, Uruguai e Venezuela, que concordaram em iniciar discussões com vistas a concluir um acordo comum $^{248}$.

${ }^{245}$ UNITED NATIONS CONFERENCE ON TRADE AND DEVELOPMENT. World investment forum 2014: investing in sustainable development. IIA Conference - 16 October 2014. Daniel Godinho. Disponível em: <http://unctad-worldinvestmentforum.org/wp-content/uploads/2014/10/Godinho.pdf>. Acesso em: 16 dez. 2014.

${ }^{246}$ Destaca-se que a primeira reunião para a negociação de um ACFI com o Chile foi realizada em agosto de 2015. Para mais informações: I REUNIÓN CHILE-BRASIL PARA LA NEGOCIACIÓN DE UN ACUERDO SOBRE COOPERACIÓN Y FACILITACIÓN DE LAS INVERSIONES, 1. 2015. Disponível em: $<$ http://sice.oas.org/whatsnew_pending/CHL_BRZ_to_negotiate_Accord_on_Coop_Investment_s.pdf >. Acesso em: 27 out. 2015.

${ }^{247}$ BRASIL. Ministério das Relações Exteriores. Nota 244 Acordo Brasil-Malaui de Cooperação e Facilitação de Investimentos (ACFI), Brasília, 25 de junho de 2015. Disponível em: $<$ http://www.itamaraty.gov.br/index.php?option=com_content\&view=article\&id=10333:acordo-brasilmalaui-de-cooperacao-e-facilitacao-de-investimentos-acfi\&catid=42\&lang=pt-BR\&Itemid=280 $>$. Acesso em: 25 jun 2015 .

${ }^{248}$ UNITED NATIONS CONFERENCE ON TRADE AND DEVELOPMENT. Investment policy monitor.

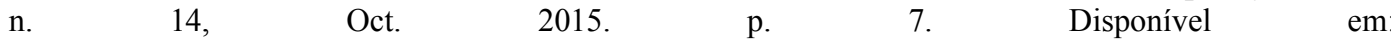
$<$ http://unctad.org/en/PublicationsLibrary/webdiaepcb2015d14_en.pdf?utm_source=World+Investment + 
As características do ACFI brasileiro englobam, por um lado, similaridades com os APPRIs tradicionais, e de outro, algumas inovações para os padrões brasileiros, além de incluir práticas dominantes nos acordos de investimento mais recentes, como por exemplo, a inclusão de cláusulas relacionadas ao desenvolvimento sustentável ${ }^{249}$. Entretanto, tem-se que as cláusulas dos acordos são moduláveis de acordo com o interesse das partes signatárias ${ }^{250}$. Neste contexto, faz-se necessário pormenorizar as principais cláusulas do ACFI brasileiro, para melhor compreender o intuito desses tratados e suas questões de fundo.

a) Preâmbulo e Objetivos

A estrutura básica de um APPRI inicia-se com um preâmbulo e nos ACFIs não é diferente. No ACFI brasileiro o preâmbulo é enfático ao enunciar a intenção de aproximação e cooperação entre as partes, e a necessidade de se estimular, agilizar e apoiar os investimentos bilaterais entre os países ${ }^{251}$, bem como a atenção que deve ser dispendida ao desenvolvimento sustentável na promoção e proteção dos investimentos ${ }^{252}$.

Network+\%28WIN\%29\&utm_campaign $=1$ daa03da05-

Blog + Post $+\% 231 \& u t m \_$medium $=$email\&utm_term $=0 \_646 a 30 \mathrm{~cd} 0-1$ daa03da05-70020601>. Acesso em: 27 out. 2015.

${ }^{249}$ GORDON, K., POHL, J.; BOUCHARD, M. Investment Treaty Law, Sustainable Development and Responsible Business Conduct: a Fact Finding Survey, OECD Working Papers on International Investment, 2014. Observa-se que este alinhamento entre a promoção e proteção de investimentos e o desenvolvimento sustentável remete ao tratado multilateral de investimentos alternativo propugnado pelo International Institute for Sustainable Development (IISD), que já enunciava em seu preâmbulo também o pilar do desenvolvimento sustentável, aliado aos direitos humanos, transparência, dentre outros. Cf. MANN, Howard; VON MOLTKE, Konrad; PETERSON, Luke Eric; COSBEY, Aaron. IISD Model International Agreement on Investment for Sustainable Investment: negotiator's handbook. 2nd. Winnipeg: IISD, 2006. p. x-xii.

${ }^{250}$ BRASIL. Agência Brasileira de Promoção de Exportações e Investimentos. Boletim de Facilitação de Negócios Análise e estudos de Conjuntura Internacional, ano 2.n. 3, 2015. Disponível em: $<$ http://arq.apexbrasil.com.br/portal/BoletimNegocios_Edicao03.pdf $>$. Acesso em: 6 out. 2015.

${ }^{251}$ Destaca-se que o ACFI com México vai além, e complementa a necessidade de abrir novas iniciativas de integração entre os países e o ACFI com o Malaui ressalta a necessidade de aprimoramento da agenda de comércio entre os países, também abrindo espaço para novas iniciativas de integração entre as Partes.

${ }^{252}$ De acordo com a UNCTAD: "The IIA universe is evolving with regard to substantive provisions: preestablishment commitments and sustainable development-oriented clauses are on the rise". Por isso, o preâmbulo dos ACFIs segue uma tendência dos APPRIs assinados em 2014, em que havendo 27 tratados assinados, dos 13 que tiveram seus textos publicados, a maioria inclui provisões relativas ao desenvolvimento sustentável, sendo que 11 deles preveem exceções gerais como a proteção a animais, saúde, proteção humana, direitos trabalhistas e conservação de recursos naturais. Estas últimas disposições serão encontradas no ACFI com a Colômbia. Cf. UNITED NATIONS CONFERENCE ON TRADE AND DEVELOPMENT. Recent trends in IIAs and ISDS, n. 1. Genebra: United Nations, 2015. p. 1. 
Nessa esteira, incluem-se também no preâmbulo os propósitos do crescimento econômico, da redução da pobreza, da criação de empregos, da expansão da capacidade produtiva e do desenvolvimento humano, tendo o ACFI com a Colômbia acrescentado, ainda, o reconhecimento do papel da transferência tecnológica. O ACFI com México adota uma abordagem mais tradicional ao prever a necessidade de se promover e proteger os investimentos, devido ao seu papel essencial no alcance de desenvolvimento sustentável e humano, no crescimento econômico, na redução da pobreza, na criação de postos de trabalho e na expansão da capacidade produtiva ${ }^{253}$.

Desta feita, o preâmbulo reforça a competência nacional dos Estados Partes para a livre formulação de políticas públicas e novas regulamentações sobre investimentos. O ACFI com a Colômbia reconhece o direito de as partes legislarem sobre investimentos para alcançar pretensões legítimas nas áreas da saúde, segurança e meio ambiente, entre outros. O ACFI com o México prevê que essa autonomia regulatória tem como finalidade precípua o cumprimento dos objetivos de sua política nacional. Nesta toada, todas essas previsões se tornam importantes, haja vista que a limitação do espaço regulatório do Brasil era um dos principais temores dos congressistas nos anos 1990.

Outrossim, o acordo visa também impulsionar e estreitar os contatos entre os setores público e privado dos Governos de ambos os países, instituindo mecanismo de diálogo técnico e inciativas governamentais que contribuam para o aumento significativo dos investimentos mútuos entre os países.

Por fim, o objetivo dos acordos deixa bem destacado os pilares já enunciados: (i) a governança institucional; (ii) os mecanismos para a mitigação de riscos e a prevenção e solução de controvérsias e (iii) o marco institucional para a implementação de agendas temáticas para a cooperação e facilitação dos investimentos. Assim, percebe-se a intenção da ação concatenada entre as agências governamentais, através de ação diplomática, da assistência ao setor privado e da remissão às legislações domésticas quanto às principais noções por detrás do arcabouço jurídico constituído.

b) Âmbito de Aplicação e Mecanismo de Execução

${ }^{253}$ BERNASCONI-OSTERWALDER, Nathalie; BRAUCH, Martin Dietrich. Comparative Commentary to Brazil's Cooperation and Investment Facilitation Agreements (CIFAs) with Mozambique, Angola, Mexico, and Malawi. International Institute for Sustainable Development (IISD), p.1-16, September 2015, p.2. Disponível em: <https://www.iisd.org/sites/default/files/publications/commentary-brazil-cifasacfis-mozambique-angola-mexico-malawi.pdf $>$. Acesso em: 15 set. 2015. 
As previsões do âmbito de aplicação encontram-se explícitas apenas nos ACFIs com México e Colômbia. Ambos os acordos estipulam que estes englobarão os investimentos realizados antes ou depois de sua entrada em vigor, ou seja, haverá proteção mesmo para os investimentos já existentes a época da entrada em vigor deste instrumento. Todavia, o ACFI com o México prevê que este não poderá ser invocado para questionar algum litígio já resolvido pelo esgotamento dos recursos internos, coberto pelo manto da coisa julgada, ou reclamação relativa a um investimento que tenha sido resolvido antes da entrada em vigor do Acordo. Ademais, conforme será explicitado de forma mais profunda no capítulo 5, o âmbito de aplicação também dispõe que o ACFI com o México somente poderá ser invocado para a resolução de controvérsias no prazo prescricional de cinco anos contados a partir da data em que o investidor teve ou deveria ter tido, pela primeira vez, conhecimento dos fatos que ensejaram a controvérsia.

Importante destacar que tanto o ACFI com o México quanto o acordo com a Colômbia não limitarão de modo algum os direitos e benefícios que o direito vigente (aqui se entende o direito nacional e o direito internacional) no território de uma Parte confere a um investidor da outra Parte. Ressalta-se que a hipótese de restrição do ordenamento jurídico das Partes era uma grande preocupação do legislativo à época da análise congressual dos TBIs brasileiros da década de 1990, pois temia-se que as disposições destes tratados pudessem contrapor a legislação nacional que disciplina a entrada de capital.

Ainda, o ACFI com a Colômbia aponta que o acordo não abrange assuntos de cunho tributário, além disso, o Acordo será aplicado sem prejuízo dos direitos e obrigações assumidos pelos Estados contratantes no âmbito da Organização Mundial do Comércio.

Noutro giro, os acordos com Moçambique e Angola dispõem sobre os mecanismos de execução, pelo que os acordos serão operacionalizados pelas instituições nacionais definidas pelas duas Partes e pelo Comitê Conjunto, através de agendas temáticas de cooperação e facilitação de investimentos, e pelo fomento de mecanismos de mitigação de riscos e prevenção de conflitos, que serão examinados no capítulo 5, dentre outros instrumentos mutuamente acordados.

c) Definições 
As definições presentes nos acordos consistem em um dos aspectos materiais mais importantes dos APPRIs, ao passo que estabelecem a abrangência desse instrumento internacional. Na opinião de Sornarajah, todos os tratados procuram definir alguns dos termos que são utilizados no instrumento e essas definições possuem alguns elementos comuns que irão, por sua vez, contribuir para a compreensão do emprego dos termos na seara do Direito Internacional do Investimento. Tratam-se de características inovadoras nos tratados, que podem ser marcantes para a evolução desses acordos ${ }^{254}$.

Nos ACFIs estas variam de um acordo para outro, havendo diferenças relevantes que determinam o escopo do acordo e de suas várias obrigações. A presente análise se desenvolverá, primeiro, demonstrando as definições gerais e mais relevantes contidas nos ACFIs e, posteriormente, particularizando o ACFI com Angola, haja vista que este prevê que as definições inerentes à matéria serão reguladas em conformidade com os respectivos ordenamentos jurídicos das Partes.

\section{c.1) Características Gerais}

Como já enunciado, as cláusulas de definições presentes nos ACFIs alteram-se conforme o acordo em análise. Contudo, ao se empreender um exame geral de todos os tratados, identifica-se a existência das seguintes definições existentes no acordo brasileiro: (i) Estado Anfitrião; (ii) Investimento; (iii) Investidor; (iv) Pessoa Natural; (v) Pessoa Jurídica; (vi) Patrimônio Autônomo; (vii) Medida; (viii) Rendimentos; (ix) Território; (x) Moeda Livremente Conversível; (xi) Governança Institucional e (xii) Ombudsman.

Desse modo, evidencia-se que o corte metodológico que se pretende fazer será avaliar, principalmente, as definições de investimento e investidor, porquanto estas consistem nas acepções de maior discussão e relevância para a proteção internacional dos investimentos brasileiros no exterior, embora as outras definições sejam transversais a esse exame, já que fazem parte da operacionalização do investimento externo em território estrangeiro. Por isso, apesar de ser dada preferência a esses dois conceitos, os outros serão eventualmente elucidados ao longo do capítulo (e do trabalho).

\footnotetext{
${ }^{254}$ SORNARAJAH, M. The International Law of Foreign Investment. 3rd. New York: Cambridge
} University Press, 2010. p. 190. 
Nos ACFIs, de forma genérica, investimento significa qualquer tipo de bem (any kind of asset) ou direito pertencente ou controlado direta ou indiretamente por um investidor de uma das Partes no território da outra Parte ${ }^{255}$, com o propósito de estabelecer relações econômicas duradouras, e destinado à produção de bens e serviços no Estado Anfitrião $^{256}$.

Assim como nos TBIs brasileiros dos anos 1990, essa definição permanece ampla. No entanto, a inovação reside na necessidade de haver relação econômica duradoura voltada para a produção de bens e serviços. Os dois elementos apresentados são claramente complementares, pois além de se especificar a maior de duração do investimento, não basta que ele exista; este deve estar ligado alguma atividade econômica em território do Estado receptor, seja relacionada a bens, seja voltada a serviços.

Essa definição mandatória se corrobora com o critério da permanência, já versado pelo Fundo Monetário Internacional (FMI), no Balance of Payments Manual (1993, p. 86), que ao conceituar investimento direto, aduz:

"O investimento direto é a categoria de investimento internacional que reflete o objetivo de uma entidade residente numa economia de obter um interesse duradouro numa empresa residente noutra economia. [...] O interesse duradouro implica na existência de uma relação de longo prazo entre o investidor direto e a empresa e um grau significativo de influência por parte do investidor na gestão da empresa" ${ }^{, 257}$. (tradução da autora)

Além disso, o enfoque apresentado também se adequa ao critério da produção, ao exigir que os bens ou direitos devem ser utilizados para a produção de bens e serviços. Assim, os dois critérios, presentes nos ACFIs, trazem a simbiose para uma compreensão mais efetiva do que é investimento externo. Todavia, os ACFIs (com exceção o firmado com Angola) têm apresentado também uma lista exemplificativa do que pode ser

${ }^{255}$ O ACFI com o México acrescenta que este bem ou direito pertencente ou sob controle do investidor deve estar em conformidade com as leis e regulamentos da outra Parte. Cf. BRASIL. Acordo e Cooperação e Facilitação de Investimentos entre a República Federativa do Brasil e os Estados Unidos do México. Brasília, 26 de maio 2015.2 Disponível em: $<$ http://investmentpolicyhub.unctad.org/Download/TreatyFile/3458>. Acesso em: 30 set. 2015. art. $3^{\circ}, \S$ 1.2 .

${ }^{256}$ BRASIL. Acordo e Cooperação e Facilitação de Investimentos entre a República Federativa do Brasil e a República do Maláui. Brasília, 25 de junho de 2015. Disponível em: $<$ http://investmentpolicyhub.unctad.org/Download/TreatyFile/3472>. Acesso em: 30 set. 2015. art. $2^{\circ}$.

${ }^{257} \mathrm{Na}$ versão original: "Direct investment is the category of international investment that reflects the objective of a resident entity in one economy obtaining a lasting interest in an enterprise resident in another economy. [...] The lasting interest implies the existence of a long-term relationship between the direct investor and the enterprise and a significant degree of influence by the investor on the management of the enterprise". INTERNATIONAL MONETARY FUND. Balance of payments manual. 15th. Washington: IMF, 1993. p. 86. 
considerado investimento $^{258}$. Nesse diapasão, enuncia-se de forma exemplificativa, através do art. $2^{\circ}, \S 1^{\circ}$, do ACFI com Malaui, que investimentos podem ser:

(i) quotas, ações, e outra participação acionária (“equity”) e instrumentos da dívida da empresa ou de outra empresa; (ii) empréstimos a empresas; ${ }^{259}$ (iii) propriedade móvel ou imóvel, bem como quaisquer outros direitos de propriedade, tais como hipoteca, penhora, garantia, usufruto; (iv) créditos pecuniários ou quaisquer obrigações derivadas de contrato com valor econômico; (v) o valor investido com base em direitos de concessão ou em decisão administrativa, incluindo licenças para cultivar, extrair ou explorar recursos naturais $^{260}$.

Adicionalmente, os ACFIs assinados com México e Colômbia acrescentam, ainda, que podem ser considerados investimentos os direitos de propriedade intelectual, tal como definidos ou se faça referência ao Acordo sobre Aspectos dos Direitos de Propriedade Intelectual Relacionados ao Comércio (TRIPS), estabelecido no âmbito da Organização Mundial do Comércio (OMC). Esta previsão encontra-se em plena consonância com o tratado bilateral de investimentos dos Estados Unidos (2004 e 2012), que também abrange os direitos de propriedade intelectual.

Ademais, o acordo com o México estabelece que o investimento deve pertencer ou ser controlado direta ou indiretamente por um investidor estabelecido ou adquirido em conformidade com as leis e regulações da outra Parte no território desta. No entendimento de Bernasconi-Osterwalder e Brauch, essa disposição se torna importante ao passo que pode excluir da definição de investimentos, por exemplo, aqueles estabelecidos de forma

${ }^{258}$ Conforme os ensinamentos da UNCTAD e contextualizando para o âmbito dos ACFIs, trata-se de uma closed-list definition accompanied by a list of examples. Cf. UNITED NATIONS CONFERENCE ON TRADE AND DEVELOPMENT. Bilateral investment treaties 1995-2006: trends in investment rulemaking. New York; Geneva: United Nations, 2007. p. 10-13.

${ }^{259} \mathrm{O}$ art. $3^{\circ}, \S 1.2$ do ACFI do México particulariza os instrumentos de dívida de uma empresa, quando a empresa se tratar de filial do investidor ou quando a data de vencimento original do instrumento de dívida seja de pelo menos três anos, contudo, não inclui um instrumento de dívida de uma Parte, independentemente da data original do vencimento, e os empréstimos a uma empresa, quando a empresa se tratar de filial do investidor e quando a data de vencimento original do empréstimo seja de pelo menos três anos, porém, não inclui um empréstimo a uma Parte, independentemente da data original do vencimento. Cf. BRASIL. Acordo e Cooperação e Facilitação de Investimentos entre a República Federativa do Brasil e os Estados Unidos do México. Brasília, 26 de maio de 2015. Disponível em: $<$ http://investmentpolicyhub.unctad.org/Download/TreatyFile/3458>. Acesso em: 30 set. 2015. art. $3^{\circ}, \S$ 1.2 .

${ }^{260}$ BRASIL. Acordo e Cooperação e Facilitação de Investimentos entre a República Federativa do Brasil e a República do Maláui. Brasília, 25 de junho de 2015. Disponível em: $<$ http://investmentpolicyhub.unctad.org/Download/TreatyFile/3472>. Acesso em: 30 set. 2015. art.art. $2^{\circ}$, $\S 1$. 
ilícita, mediante corrupção ou fraude, na medida em que as legislações das Partes condenem e atribuam responsabilidade a esse tipo de prática $^{261}$.

Nesse ínterim, o mesmo acordo institui que os instrumentos de dívida de uma firma ou empréstimos a uma empresa só serão considerados investimento quando a empresa é uma filial do investidor e quando a data do vencimento original do instrumento da dívida ou empréstimo seja de pelos menos três anos, porém não inclui um instrumento de dívida de uma Parte, independentemente da data original do vencimento. Entretanto, para que se possa munir maior grau de certeza sobre as definições em tela, os acordos com Malaui, México e Colômbia também dispõem sobre o que não deve ser considerado investimento. Dentro do escopo do ACFI com o Malauí, em seu art. 5, item "v", veja-se:

Para maior clareza, a definição de investimentos não inclui:

(i) títulos de dívida emitidos por um governo ou empréstimos concedidos a um governo; (ii) investimentos de portfólio; (iii) créditos pecuniários decorrentes exclusivamente de contratos comerciais para a venda de bens e de serviços por um nacional ou empresa no território de uma Parte para uma empresa no território de outra Parte, ou concessão de crédito em conexão com uma transação comercial, ou qualquer outra reivindicação pecuniária que não envolva as situações estabelecidas nas alíneas (i)-(v) acima ${ }^{262}$.

Noutro giro, quanto à definição de investidor, de forma geral, o acordo brasileiro adota o critério da nacionalidade, em que é investidor o indivíduo nacional de uma das Partes e que invista noutra Parte; além desse critério, para as pessoas jurídicas adota-se os elementos de conexão Estado de constituição da empresa e local da sede ou do centro da administração do investimento caso a empresa seja estruturada de acordo com a lei de uma das Partes. Caso não o seja, considera-se o critério do controle por um investidor. Importante destacar que a adoção desta última definição se coaduna com os preceitos aventados pela CIJ no paradigmático caso Barcelona Traction ${ }^{263}$, exposto no capítulo 2.

A título ilustrativo, os principais preceitos acerca da definição de investidor podem ser identificados conforme disposto no art. $3^{\circ}, \S 1.3$ do ACFI com o México:

${ }^{261}$ BERNASCONI-OSTERWALDER, Nathalie; BRAUCH, Martin Dietrich. Comparative Commentary to Brazil's Cooperation and Investment Facilitation Agreements (CIFAs) with Mozambique, Angola, Mexico, and Malawi. International Institute for Sustainable Development (IISD), p.1-16, September 2015. p. 4. Disponível em: <https:/www.iisd.org/sites/default/files/publications/commentary-brazil-cifasacfis-mozambique-angola-mexico-malawi.pdf $>$. Acesso em: 15 out. 2015.

${ }^{262}$ BRASIL. Acordo e Cooperação e Facilitação de Investimentos entre a República Federativa do Brasil e a República do Maláui. Brasília, 25 de junho de 2015. art. 2o, item "v". Disponível em: $<$ http://investmentpolicyhub.unctad.org/Download/TreatyFile/3472>. Acesso em: 30 set. 2015.

${ }^{263}$ INTERNATIONAL COURT OF JUSTICE. Case concerning the Barcelona Traction, Light and Power Company Limited (Belgium v. Spain). Judgement, 5 fev. 1970. ICJ Reports, 1970. p. 3. Disponível em: $<$ http://www.icj-cij.org/docket/files/50/5387 pdf >. Acesso em: 30 out. 2015. 
"Investidor significa:

a) qualquer pessoa natural que seja nacional de uma das Partes, em conformidade com sua legislação, e que faça um investimento em outra Parte; b) qualquer pessoa jurídica estruturada de acordo com a legislação de uma Parte que tenha sua sede e o centro das suas atividades econômicas no território dessa Parte, e que faça um investimento na outra Parte; ou c) qualquer pessoa jurídica não estruturada de acordo com a legislação de qualquer das Partes, mas controlada por um investidor de uma Parte, de acordo com os incisos (a) ou (b), e que faça um investimento em outra Parte"264. (BRASIL, 2015).

Nota-se que o ACFI com a Colômbia destaca que investidor significa "uma pessoa natural, uma pessoa jurídica ou um patrimônio autônomo de uma parte que tenha realizado um investimento no território da outra Parte" ${ }^{265}$. Deste excerto se extrai, respectivamente, que conforme o acordo (i) pessoa jurídica refere-se a qualquer entidade constituída ou organizada conforme legislação de uma Parte, tenha ou não fins lucrativos, seja propriedade pública ou privada, e que tenha domicílio e atividades substanciais no território do Estado receptor. Assim, a novidade reside no fato de o acordo esclarecer que o investidor não se restringirá apenas ao investidor privado, podendo abarcar também o setor público; e (ii) considera-se também investidor o patrimônio autônomo, que segundo o próprio documento, significa o conjunto de bens submetidos a um regime jurídico, que seja separável e independente do patrimônio de quem o transferiu, do patrimônio de quem é seu titular para efeitos de administração e do patrimônio do beneficiário.

Destarte, o ACFI com o Malauí melhor esclarece, em seu art. 2º $§ 2$, letra "c", que investidor significa, semelhantemente ao acordo com o México, pessoa "cuja propriedade ou controle efetivo pertença, direta ou indiretamente, a nacionais ou residentes permanentes das Partes, de acordo com a legislação correspondente"266 . Essa previsão se torna benéfica ao passo que o critério domiciliar utilizado aumenta o padrão de proteção existente, que não se foca apenas no nacional do Estado de origem, mas também no

${ }^{264}$ BRASIL. Acordo e Cooperação e Facilitação de Investimentos entre a República Federativa do Brasil e os Estados Unidos do México. Brasília, 26 de maio de 2015. Disponível em: $<$ http://investmentpolicyhub.unctad.org/Download/TreatyFile/3458>. Acesso em: 30 set. 2015. art. $2^{\circ}, \S$ 1.3 .

${ }^{265}$ BRASIL. Acordo e Cooperação e Facilitação de Investimentos entre a República Federativa do Brasil e o Governo da República da Colômbia. Bogotá, 9 de outubro de 2015. Disponível em: $<$ http://www.itamaraty.gov.br/images/ed_atosinter/20151009-ACFI-port2.pdf $>$. Acesso em: 10 out. 2015. art. $3^{\circ}, \S 1.3$.

${ }^{266}$ BRASIL. Acordo e Cooperação e Facilitação de Investimentos entre a República Federativa do Brasil e os Estados Unidos do México. Brasília, 26 de maio de 2015. Disponível em: $<$ http://investmentpolicyhub.unctad.org/Download/TreatyFile/3458>. Acesso em: 30 set. 2015. art. $2^{\circ}$, $\S 2^{\circ}$, letra c. 
residente permanente que neste país vive, o qual poderá investir noutro território ${ }^{267}$. É o caso, por exemplo, se um nacional proveniente de um terceiro país residisse permanentemente no Brasil e decidisse investir no Malaui, ação que se corroboraria com os preceitos dispostos no acordo.

Segundo Salacuse e Sullivan, a complexidade ocorre quando o investidor possui dupla nacionalidade ${ }^{268}$. O ACFI com a Colômbia traz à baila a questão da pessoa natural binacional, pelo que o acordo não se aplicará aos investimentos de pessoas naturais que sejam nacionais das duas partes contratantes, a menos que as referidas pessoas naturais, no momento do investimento e desde então, sem interrupção, tenham tido domicílio fora do território do Estado Parte.

\section{c.2) O ACFI com Angola}

A legislação nacional sobre investimentos estrangeiros consiste no conjunto de normas de caráter unilateral adotadas pelo Estado, com a finalidade de delimitar o regime aplicável ao investimento estrangeiro desde a sua constituição até a sua liquidação. Quanto ao ACFI com Angola, ele é o único que não detém definições próprias no texto do acordo. Em compensação, o art. $3^{\circ}$ desse instrumento dispõe que as definições inerentes à matéria serão reguladas pelos respectivos ordenamentos jurídicos das Partes.

Partindo desse pressuposto, interpreta-se que essa abertura dada pelo acordo tem como propósito garantir a ausência de previsões contraditórias entre o direito interno e o Direito Internacional, consubstanciado nos acordos de investimento, restringindo apenas à conceituação doméstica. No entanto, vale destacar que essa abordagem sugere algumas complicações.

Primeiro, não está claro de qual direito doméstico se está falando ${ }^{269}$. Neste caso, mesmo levando em conta a previsão do art. 31 da Convenção de Viena sobre o Direito dos

${ }^{267}$ COSTA, José Augusto Fontoura. Direito Internacional do Investimento Estrangeiro. Curitiba: Juruá, 2010. p. 135.

${ }^{268}$ SALACUSE, Jeswald W.; SULLIVAN, Nicholas P. Do BITs really work? An evaluation of bilateral investment treaties and their grand bargain. Harvard International Law Journal, n. 46, p.67-130, 2005. p. 81.

${ }^{269}$ Segundo Bernasconi-Osterwalder e Brauch, é provável que as partes tinham em mente, ao elaborar esta redação, o direito do Estado receptor de investimentos. Cf. BERNASCONI-OSTERWALDER, Nathalie; BRAUCH, Martin Dietrich. Comparative Commentary to Brazil's Cooperation and Investment Facilitation Agreements (CIFAs) with Mozambique, Angola, Mexico, and Malawi. International Institute for Sustainable Development (IISD), p.1-16, September 2015. p. 3 Disponível em: 
Tratados (CVDT), tentando-se empreender uma interpretação baseada na boa-fé, no sentido comum dos termos empregados no tratado e à luz de seu objeto e finalidade, esta amplitude faz com que se pressuponha que o direito aplicado quanto às definições será tanto o direito doméstico de Brasil, quanto o de Angola. Isso significa que estas irão variar de um país para outro e, ainda, se as definições internas de cada país também se alterarem, dependendo da lei ou regulamento, isso implicará em uma discrepância ainda maior dessas definições.

Ocorre que mesmo que se estabeleça que será aplicado o direito doméstico de cada país, o fato também é que poderá haver futuramente não apenas uma definição única no direito doméstico brasileiro ou angolano para certo termo, mas pode haver mais de uma, levando em consideração todo o arcabouço jurídico doméstico. Isso dificulta a determinação de um ponto de referência certeiro para os efeitos das definições do presente acordo, trazendo imprevisibilidade às relações.

Como já enunciado, o Brasil não tem propriamente uma lei de investimento e, no âmbito doméstico, o instrumento jurídico utilizado é a Lei $\mathrm{n}^{\circ} 4.131 / 62$, mais conhecida como Lei de Remessa de Lucros ou Lei do Capital Estrangeiro ${ }^{270}$. Esta lei não regula inteiramente a disciplina de investimentos, apenas gerindo a aplicação do capital estrangeiro e as remessas de valores para o exterior. Para os efeitos desta lei, consideramse capitais estrangeiros os bens, máquinas e equipamentos entrados no Brasil sem dispêndio inicial de divisas destinados à produção de bens ou serviços, bem como os recursos financeiros ou monetários introduzidos no país para aplicação em atividades econômicas desde que, em ambas as hipóteses, pertençam a pessoas físicas ou jurídicas residentes, domiciliadas ou com sede no exterior ${ }^{271}$.

Conforme interpretação extensiva do art. $7^{\circ}$ da Lei $n^{\circ} 4.131 / 62$, também podem ser considerados investimentos os reinventimentos auferidos por empresas estabelecidas no País e atribuídos a residentes e a domiciliados no exterior, e que forem reaplicados nas

$<$ https://www.iisd.org/sites/default/files/publications/commentary-brazil-cifas-acfis-mozambique-angolamexico-malawi.pdf>. Acesso em: 15 set. 2015.

${ }^{270}$ Ressalta-se que, inicialmente, a lei 4131 de 1962 foi regulamentada pelo Decreto ${ }^{\circ} 55.451$ de 1964 , contudo, por ultrapassar os limites regulatórios de um decreto, este foi revogado pela Lei $\mathrm{n}^{\circ} 4.390$ de 1964, que alterou a lei ${ }^{\circ} 4.131$ de 1962 , tendo a lei de 1964 sido regulamentada, depois, pelo Decreto ${ }^{\circ}$ 55.762 de 1965.

${ }^{271}$ BRASIL. Lei ${ }^{\circ} 4.131$, de 3 de setembro de 1962. Disciplina a aplicação do capital estrangeiro e as remessas de valores para o exterior e dá outras providências. Diário Oficial [da] República Federativa do Brasil, Brasília, 27 de setembro de 1962. art. $1^{\circ}$. 
mesmas empresas de que procedem ou em outro setor da economia nacional ${ }^{272}$. Isso, pois, a noção de investimento exige ao mesmo tempo um retorno do mesmo, que é limitado ao sucesso do empreendimento ${ }^{273}$ e que deve ser destinado à produção de bens, serviços ou outras atividades lucrativas. Ademais, a Lei n ${ }^{\circ}$ 4.131/62 não explicita claramente quem são os investidores, mas aduz no mesmo art. $1^{\circ}$ que a procedência do capital deve advir de pessoas físicas ou jurídicas residentes, domiciliadas ou com sede no exterior.

Em Angola, o arcabouço jurídico relativo aos investimentos estrangeiros e aplicado aos investimentos privados de maneira geral era a Lei $n^{\circ} 20 / 11$, porém, esta foi revogada, em agosto de 2015, após a assinatura do ACFI entre Brasil e Angola, pela Lei $n^{\circ} 14 / 15$, a nova Lei do Investimento Privado. Na Lei $n^{\circ} 20 / 11$, o art. $2^{\circ}$ previa, nos seguintes termos, as definições relevantes para análise:

\begin{abstract}
Artigo $2^{\circ}$
(Definições)

Para efeitos da presente lei, considera-se:

a) investimento privado - a utilização no território nacional de capitais, tecnologias e know how, bens de equipamento e outros, em projectos económicos determinados, ou a utilização de fundos que se destinam à criação de novas empresas, agrupamentos de empresas ou outra forma de representação social de empresas privadas, nacionais ou estrangeiras, bem como a aquisição da totalidade ou parte de empresas de direito angolano já existentes, com vista à implementação ou continuidade de determinado exercício económico de acordo com o seu objecto social, desde que estes investimentos sejam qualificáveis como tal, nos termos do artigo $3 .^{\circ}$ da presente lei; [...]

c) investidor privado - qualquer pessoa, singular ou colectiva, residente ou não, independentemente da sua nacionalidade, que realize no território nacional investimentos destinados aos fins referidos na alínea a); [...]

f) investimento externo -a introdução e utilização em Angola, com o recurso a activos domiciliados:

i. dentro e fora do território nacional, por pessoas singulares ou coletivas, não residentes cambiais, de capitais, tecnologias e knowhow, bens de equipamentos e outros, em projectos económicos determinados, ou ainda a utilização daqueles fundos na criação de novas empresas, agrupamentos de empresas, ou outra forma de representação social de empresas privadas nacionais ou estrangeiras, bem como a aquisição da totalidade ou parte de empresas de direito angolano já existentes, com vista à implementação ou continuidade de determinada actividade económica, de acordo com o seu objecto social; ii. fora do território nacional, por pessoas singulares ou colectivas residentes cambiais, de capitais, tecnologias e know how, bens de equipamentos e outros, em projectos económicos determinados ou ainda a utilização daqueles fundos na criação de novas empresas, agrupamentos de empresas, ou outra forma de representação social de empresas privadas, nacionais ou estrangeiras, bem como a aquisição da totalidade ou parte de empresas de direito angolano já existentes, com vista à implementação ou continuidade de determinado exercício económico, de acordo
\end{abstract}

${ }^{272}$ BRASIL. Lei ${ }^{\circ} 4.131$, de 3 de setembro de 1962. Disciplina a aplicação do capital estrangeiro e as remessas de valores para o exterior e dá outras providências. Diário Oficial [da] República Federativa do Brasil, Brasília, 27 de setembro de 1962. art. $7^{\circ}$.

273 BAPTISTA, Luiz Olavo. Investimentos Internacionais no Direito Comparado e Brasileiro. Porto Alegre: Livraria do advogado, 1998, p. 52. 
com o seu objecto social; iii. para efeitos do disposto na alínea anterior, relativamente aos capitais não domiciliados em território nacional oriundos do recurso a crédito, deve a sua amortização ser realizada sem recurso ao Fundo Cambial de Angola

g) investidor externo - qualquer pessoa, singular ou colectiva, residente cambial ou não, independentemente da sua nacionalidade, que introduza ou utilize no território nacional, nos termos da alínea anterior, capitais domiciliados no exterior de Angola, com direito a transferir lucros e dividendos para o exterior; h) reinvestimento externo - aplicação em território nacional da totalidade ou de parte dos lucros gerados em virtude dum investimento externo e que, nos termos da presente lei, sejam passíveis de exportação, devendo o mesmo obedecer às mesmas regras a que está sujeito o investimento externo;

i) investimento indirecto - todo o investimento interno ou externo que compreenda, isolada ou cumulativamente, as formas de empréstimo, suprimento, prestações suplementares de capital, tecnologia patenteada, processos técnicos, segredos e modelos industriais, franchising, marcas registadas, assistência técnica e outras formas de acesso à sua utilização, seja em regime de exclusividade ou de licenciamento restrito por zonas geográficas ou domínios de actividade industrial e/ou comercial;

j) investimento directo - todo o investimento, interno ou externo, realizado em todas as formas que não caibam na definição de investimento indirecto, referidas na alínea anterior; $[\ldots] .{ }^{274}$

Já na Lei $n^{\circ} 14 / 15$, o art. $4^{\circ}$ também elenca algumas definições. Dentre elas, as mais importantes para o presente estudo são:

Artigo $4^{\circ}$

(Definições)

Para efeitos da presente Lei, considera-se:

$[\ldots]$

e) <<investimento privado $>>$, utilização no território nacional de capitais, tecnologias e know how, bens de equipamento e outros em projetos económicos determinados ou a utilização de fundos que se destinam à criação de novas empresas, agrupamentos de empresas ou outra forma de representação social de empresas privadas, nacionais ou estrangeiras, bem como a aquisição da totalidade ou parte de empresas de direito angolano já existentes, com vistas à implementação ou continuidade de determinado exercício económico de acordo com o seu objeto social; [...]

h) $<<$ investimento externo $>>$, realização de projeto por via da utilização de capitais titulados por não residentes, podendo estes para além de meios monetários, adoptar igualmente a forma de tecnologias e know how e bens de equipamento;

i) $<<$ investimento directo $>>$, todo investimento, interno ou externo, realizado em todas as formas que não caibam na definição de investimento indirecto;

j) $<<$ investimento indirecto $>>$, todo o investimento interno ou externo que compreenda, isolada ou cumulativamente, as formas de empréstimo, suprimento, prestações suplementares de capital, tecnologia patenteada, processos técnicos, segredos e modelos industriais, franchising, marcas registradas e outras formas de acesso à sua utilização, seja em regime de exclusividade ou de licenciamento restrito por zonas geográficas ou domínios de atividade industrial e/ou comercial; $[\ldots]$

${ }^{274}$ ANGOLA. Lei $n^{\circ}$ 20/11, de 19 de maio de 2011. Lei do Investimento Privado. Diário da República Órgão Oficial da República de Angola, Luanda, 20 mai. 2011. Disponível em: $<$ http://www.wipo.int/edocs/lexdocs/laws/pt/ao/ao027pt.pdf $>$. Acesso em: 15 out. 2015. art. $2^{\circ}$. 
1) $<<$ investidor privado $>>$, qualquer pessoa, singular ou colectiva, que independentemente da sua nacionalidade ou domić́lio realize no território nacional, investimentos destinados aos fins referidos na alínea e);

m) $<<$ investidor externo $>>$, qualquer pessoa, singular ou colectiva, que realize investimentos nos termos da alínea $\mathrm{h}$ ) do presente artigo; [...]

p) $<<$ reinvestimento externo $>>$, aplicação em território nacional da totalidade ou de parte dos lucros gerados em virtude dum investimento externo e que, nos termos da presente Lei, sejam passíveis de exportação, devendo o mesmo obedecer às mesmas regras a que está sujeito o investimento externo; [...]"275 .

Assim, ao se comparar as legislações supracitadas, observa-se que as duas leis angolanas são distintas da lei brasileira quanto à conceituação de investimentos. Primeiramente, o investimento externo para Angola é bem mais amplo nas duas leis, pois abrange não só bens e equipamentos destinados à produção econômica ou recursos financeiros e monetários com finalidade de aplicação econômica, mas também envolve tecnologias e know how. Na lei angolana $\mathrm{n}^{\circ}$ 20/11 incluem-se ainda projetos econômicos, fundos na criação de novas empresas, agrupamentos de empresas, ou outra forma de representação social de empresas privadas, nacionais ou estrangeiras, a aquisição da totalidade ou parte de empresas de direito angolano já existente, para a implementação ou continuidade de determinada atividade econômica, o que está previsto na Lei $\mathrm{n}^{\circ} 14 / 15$ quando se define o conceito de investimentos privados.

Em segundo lugar, ambas as leis angolanas fazem a diferenciação entre investimento direto e indireto. Este corresponde, nas duas leis, a todo o investimento interno ou externo que compreenda, isolada ou cumulativamente, as formas de empréstimo, suprimento, prestações suplementares de capital, tecnologia patenteada, processos técnicos, segredos e modelos industriais, franchising, marcas registadas, e outras formas de acesso à sua utilização, seja em regime de exclusividade ou de licenciamento restrito por zonas geográficas ou domínios de atividade industrial e/ ou comercial; e aquele diz respeito ao investimento, interno ou externo, realizado em todas as formas que não caibam na definição de investimento indireto anteriormente exposta.

Ademais, tanto a legislação antiga, como a mais atual de Angola também dispõem sobre a definição de reinvestimento externo, qual seja a aplicação em território nacional da totalidade ou de parte dos lucros gerados em virtude de um investimento externo e que, nos

\footnotetext{
${ }^{275}$ ANGOLA. Lei $n^{\circ}$ 14/15, de 07 de agosto de 2015. Lei do Investimento Privado. Diário da República Órgão Oficial da República de Angola, Luanda, 11 ago. 2015. Disponível em: <http://www.embangolacan.org/pdf/LEI\%20DO\%20INVESTIMENTO\%20PRIVADO\%20\%20NOVA\%20_PORTUGUES.PDF>. Acesso em: 27 set. 2015. art. $4^{\circ}$.
} 
termos da presente lei, sejam passíveis de exportação, devendo o mesmo obedecer às mesmas regras que sujeitam o investimento externo.

Por fim, diferentemente da lei brasileira, a lei angolana possui definição específica para investidor estrangeiro. Conforme o ditame legal da Lei $\mathrm{n}^{\circ} 14 / 15$, investidor significa qualquer pessoa, singular ou coletiva, que realize investimentos nos termos da alínea $h$ ) do art. $4^{\circ}$ supracitado. A lei revogada $n^{\circ} 20 / 11$ previa definição mais descritiva, englobando qualquer pessoa, singular ou coletiva, residente cambial ou não, independentemente da sua nacionalidade, que introduza ou utilize no território nacional capitais domiciliados no exterior, com direito a transferir lucros e dividendos para o exterior. Nesse sentido, aduz-se que o critério da nacionalidade não é empregado nesta definição (nem na definição mais recente), contudo, interessante notar que ela enaltece o direito da livre transferência ao estipular o direito de deslocamento de lucros e dividendos para o estrangeiro.

Desta feita, conclui-se que a falta de conceitos bem estabelecidos leva à utilização de definições nacionais, em última análise, criando a coexistência de diferentes versões de um mesmo conceito. Além disso, este emprego permite que os Estados alterem a amplitude da aplicação do acordo a qualquer momento através da mudança na definição existente nas leis nacionais, apesar de no caso específico de Angola essa variação não ter sido tão significativa com a atualização da Lei de Investimentos Privados em 2015.

Nesse mesmo sentido, salienta-se que definições nacionais podem não ser as mais apropriadas com o contexto atual, já que são concebidas para fins específicos de uma determinada lei, como é o caso, por exemplo, da Lei $n^{\circ} 4.131 / 62$, que trata da aplicação do capital estrangeiro e da remessa de lucros e das leis angolanas, que tratam apenas dos investimentos privados (ao passo que os investimentos estrangeiros também podem ser públicos).

Todavia, entende-se que mesmo nos casos em que não há referência explícita às leis nacionais, a falta de uma definição clara e adequada cria um obstáculo interpretativo às Partes. Contudo, o auxílio para se concretizar esta interpretação não pode ser realizado por meio de outras fontes do direito, como por exemplo outros tratados de investimento, haja vista que não há uma interpretação unívoca acerca das definições aventadas, como por exemplo a de investimentos e investidor, bem como cada tratado de investimentos possui uma cobertura. Por isso, faz-se necessário que existam definições nos acordos de investimento, ao invés de se recorrer ao direito interno para tanto, não obstante, estas devem ser apropriadas para que se possa atingir uma interpretação internacional adequada. 
d) Tratamento Outorgado aos Investidores e a seus Investimentos

Os acordos de promoção e proteção de investimento, de forma geral, contêm padrões específicos de tratamento, diretrizes mandatórias a serem seguidas pelas partes contratantes no tratamento de investimentos e investidores estrangeiros em território nacional. A primeira destas, prevista em todos os ACFIs, trata-se da disposição sobre a admissão e estabelecimento do investimento. De acordo com o disposto no art. $11, \S 1^{\circ}$ do ACFI com Moçambique: "cada Parte, nos termos de seu ordenamento jurídico, deve permitir e encorajar a realização de investimentos da outra Parte no seu território e criar condições favoráveis que as disponíveis para outros investidores domésticos"276.

Nesse ínterim, o ACFI com Angola, apesar de incentivar a disseminação da oportunidade de investimentos nos Estados contratantes, faz ressalva expressa à admissão de certos investimentos de acordo com os respectivos ordenamentos internos das Partes. De acordo com Anna Joubin-Bret, a remissão ao direito doméstico das partes trata-se de alusão a princípio de direito internacional reconhecido, em que os Estados detêm o direito soberano de regular a admissão dos investidores estrangeiros em sua economia, recusar a entrada ou instituir condições para a entrada e operação dos estrangeiros ${ }^{277}$.

Isso faz com que se interprete que o previsto no ACFI com Angola baseia-se no Modelo de Admissão, cláusula padrão estipulada em acordos de promoção e proteção de investimento tradicionais, em que as partes encorajam a promoção de investimentos ao mesmo tempo em que atribuem as condições de entrada e estabelecimento à discrição de cada país, ou seja, conforme seus ordenamentos nacionais.

Nos termos da antiga Lei de Investimentos de Angola, Lei $n^{\circ} 20 / 11$, os seguintes setores são reservados ao Estado angolano: (i) a produção, distribuição e venda de equipamentos militares; (ii) as atividades do Banco Central; (iii) a propriedade de portos e aeroportos e (iv) serviços nacionais de telecomunicação. Para alguns outros setores e

${ }^{276}$ BRASIL. Acordo e Cooperação e Facilitação de Investimentos entre a República Federativa do Brasil e o Governo da República de Moçambique. Maputo, 30 de março de 2015. Disponível em: $<$ http:/www.itamaraty.gov.br/index.php?option=com_content\&view=article\&id=8511:acordo-brasilmocambique-de-cooperacao-e-facilitacao-de-investimentos-acfi-maputo-30-de-marco-de2015\&catid $=42 \&$ Itemid $=280 \&$ lang $=$ pt-BR $>$. Acesso em: 30 set. 2015 . art. $11, \S 1^{\circ}$.

277 JOUBIN-BRET, Anna. Admission and establishment in the context of investment protection In REINISCH, August (org.). Standards of investment protection. Oxford: Oxford University Press, p. 928, 2008. p. 10. Para um estudo mais aprofundado da soberania, ver: SCHWARZENBERGER, Georg. The Fundamental Principles of International Law. Recueil des cours, p.181-395, 1955. p. 214-227. 
atividades, nomeadamente os serviços postais básicos e serviços de telecomunicações locais, que constituam uma extensão da rede de telecomunicações nacional, faz-se necessário que o Estado seja acionista majoritário. Ademais, algumas atividades podem ser realizadas por empresas privadas por meio de contratos de concessão, são elas: saneamento básico; geração, transporte e distribuição de energia elétrica para consumo público; recolhimento, tratamento e distribuição de água potável através de redes fixas; exploração de serviços portuários e aeroportuários, o transporte ferroviário e transporte aéreo regular de passageiros em linhas aéreas domésticas; e infraestrutura de telecomunicações que não faz parte da rede nacional. Todas as outras atividades são abertas ao capital privado, incluindo investimentos estrangeiros ${ }^{278}$.

Contudo, o art. $9^{\circ}$ da Lei $n^{\circ} 14 / 15$ introduziu importantes alterações, estabelecendo a obrigatoriedade de se estabelecer uma parceria entre os investidores estrangeiros e cidadãos angolanos, empresas de capital público ou empresas angolanas, quando esteja em discussão um investimento estrangeiro em Angola nos seguintes setores prioritários de atividade: eletricidade e água; hotelaria e turismo; construção civil; telecomunicações e tecnologia da informação; e meios de comunicação social. Nessas parcerias, os cidadãos ou empresas angolanas deverão deter uma participação de pelo menos 35\% do capital social, bem como deve haver uma participação na gestão da sociedade refletida no acordo de acionistas.

$\mathrm{Na}$ lei brasileira, como já identificado, há restrições ao acesso de investidor estrangeiro em setores específicos, as quais estão inseridas na Constituição e na legislação infraconstitucional. As limitações constitucionais, hierarquicamente superiores, englobam os seguintes setores: nuclear (art.177 da CF); assistência à saúde (art. 199 da CF), setor financeiro (art. 52 do ADCT); setor de meios de comunicação social (art. 222 da CF); setor de mineração e hidroeletricidade (art. 176 da CF); setor de transporte aquático (art. 178 da CF) e setor imobiliário rural (art. 190 da CF).

No entanto, nos acordos com Maláui, México e Colômbia a redação é menos direta, prevendo apenas que a criação de condições favoráveis ao investimento deve ser realizada de acordo com o ordenamento jurídico interno. Logo, se houver restrições na legislação nacional das Partes, estas também devem ser respeitadas, o que acaba por limitar a entrada do investimento, porém, levando em consideração o tratamento nacional, que

\footnotetext{
${ }^{278}$ WORLD TRADE ORGANIZATION. Trade Policy Review: Angola. Geneva, 18 ago. 2015. p. 25.
} 
será abordado adiante. Esta restrição só valerá para o que for impossível para o investidor doméstico.

Outrossim, observa-se também a existência de outros padrões de tratamento. Apesar de não nomeados, todos os acordos insculpem o direito do tratamento nacional e da nação mais favorecida. O primeiro estabelece que cada Parte conferirá aos investidores da outra Parte e a seus investimentos tratamento não menos favorável do que aquele atribuído, em circunstâncias similares, aos investidores nacionais e a seus investimentos, ou seja, trata-se de padrão que pretende evitar a discriminação baseada na nacionalidade do agente $^{279}$.

O ACFI com a Colômbia complementa, através de rol positivo não exaustivo que esse tratamento não menos favorável deverá cobrir as circunstâncias de expansão, administração, condução, operação, venda ou outra disposição dos investimentos em seu território. Importante destacar que tanto este ACFI quanto aquele com o México especificam o que vem a ser o tratamento menos favorável, qual seja, aquele que altere as condições de concorrência em favor dos seus próprios investidores e seus investimentos, se comparado com a situação de investidores da outra Parte e seus investimentos. Ademais, os mesmos acordos dispõem que a redação do artigo e a garantia do tratamento nacional não impedirá a adoção e implementação de exigências ou restrições legais futuras aos investidores e seus investimentos, desde que não sejam discriminatórias.

Quanto à mesma cláusula, nos acordos com Angola, Malaui e Moçambique identificou-se que o tratamento nacional consiste em matéria de direito interno, além disso esses acordos englobam o tratamento nacional também na fase de pré-estabelecimento ${ }^{280}$, conforme pode-se notar no texto do ACFI com Malaui, em seu art. 10, $\S 2^{\circ}$ :

Cada Parte, observadas as exceções legalmente estabelecidas e os requisitos legais aplicáveis, permitirá aos investidores da outra Parte estabelecer investimentos e conduzir negócios em condições não menos favoráveis que as disponíveis para outros investidores domésticos ${ }^{281}$.

${ }^{279}$ BJORKLUND, Andrea K. National treatment In: REINISCH, August (Org.). Standards of investment protection. Oxford: Oxford University Press, p. 29-58, 2008. p. 29-30.

280 Segundo Anna Joubin-Bret, essa fase pode ser definida também quando estiver previsto o termo "estabelecimento" ou "aquisição". Cf. JOUBIN-BRET, Anna. Admission and establishment in the context of investment protection In: REINISCH, August (Org.). Standards of investment protection. Oxford: Oxford University Press, 9-28, 2008. p. 13.

${ }^{281}$ BRASIL. Acordo e Cooperação e Facilitação de Investimentos entre a República Federativa do Brasil e a República do Maláui. Brasília, 25 de junho de 2015. Disponível em: $<$ http://investmentpolicyhub.unctad.org/Download/TreatyFile/3472>. Acesso em: 30 set. 2015, art. 10, $\S 2^{\circ}$. 
Ignácio Gómez-Palacio e Peter Muchlinski são enfáticos ao asseverar que o direito de estabelecimento é em sua essência um padrão de não discriminação, que garante igualdade competitiva para entrada e estabelecimento no mercado ${ }^{282}$. Portanto, esta previsão se torna relevante em função da extensão da proteção do tratamento nacional para todos os estágios de vida do investimento ${ }^{283}$. Entretanto, como ensina Sornarajah, esses tratados estendem o tratamento nacional também à fase de pré-estabelecimento, porém o direito não é reconhecido como um direito absoluto, podendo as partes desses tratados continuarem realizando amplas limitações na entrada de determinados investimentos ${ }^{284}$.

Nesse diapasão, infere-se que a restrição prevista na cláusula geral sobre admissão dos investimentos é empregada para dar clareza ao fato que um Estado, em função de sua soberania, não é obrigado a aceitar investimentos que sejam incompatíveis com seu direito interno, podendo restringi-los em qualquer fase. Porém, se assim o fizer, deve-se levar em consideração também o tratamento nacional, ou seja, serão aplicáveis nos casos em que tampouco nacionais ou outros investidores estrangeiros podem investir. Assim, diante de um conflito normativo entre soberania e direito de restrição aos investimentos estrangeiros e não discriminação e tratamento nacional, a previsão deve ser interpretada, de acordo com os preceitos do art. 31 da CVDT, segundo o sentido comum aos termos do tratado e à luz de seu objetivo e finalidade, logo, de maneira a ser compatível com os padrões de tratamento estipulados.

O fato é que os acordos africanos efetuam uma mescla de dois padrões de proteção. O primeiro deles detém em suas previsões uma entrada controlada de capital estrangeiro, que reserva o direito ao Estado Anfitrião de regular a entrada do investimento em seu território; o segundo trata-se de um acordo dotado de ampla liberalização, que estende o padrão da não discriminação à fase de pré-estabelecimento do investimento, ampliando assim o escopo de proteção ${ }^{285}$.

${ }^{282}$ GÓMEZ-PALACIO, Ignacio; MUCHLINSKI, Peter. Admission and establishment In MUCHLINSKI, Peter; ORTINO, Federico; SCHREUER, Christoph (Coord).The Oxford Handbook of International Investment Law. Oxford: Oxford University Press, p. 227-258, 2008. p. 231.

283 JOUBIN-BRET, Anna. Admission and establishment in the context of investment protection In: REINISCH, August (Org.). Standards of investment protection. Oxford: Oxford University Press, 9-28, 2008. p. 13

284 SORNARAJAH, M. The International Law of Foreign Investment. 3rd. New York: Cambridge University Press, 2010. p. 104.

285 GÓMEZ-PALACIO, Ignacio; MUCHLINSKI, Peter. Admission and establishment In MUCHLINSKI, Peter; ORTINO, Federico; SCHREUER, Christoph (Coord).The Oxford Handbook of International Investment Law. Oxford: Oxford University Press, p. 227-258, 2008. p. 240. 
Ademais, verifica-se também que a redação dos ACFIs são distintas no que tange ao tratamento nacional, sendo que os ACFIs africanos preveem a fase de préestabelecimento, enquanto os ACFIs latino americanos não englobam essa peculiaridade, sendo o ACFI com o México silente quanto à sua aplicabilidade ao estabelecimento do investimento, à condução do mesmo ou se aos dois, e o da Colômbia é explícito ao não prever em seu rol positivo o estabelecimento; porém, somente estes últimos acordos caracterizam o tratamento menos favorável como aquele que altera as condições de concorrência em favor dos seus próprios investidores e seus investimentos. Ademais, importante ressaltar que para eles não há a obrigação de o tratamento nacional ser matéria de direito interno ${ }^{286}$.

Por fim, o acordo com a Colômbia, em seu art. $5^{\circ}, \S 4^{\circ}$, veda também a interpretação no sentido de obrigar as partes a compensar desvantagens competitivas intrínsecas, que resultem do caráter estrangeiro dos investidores e seus investimentos. Ora, o intuito desta norma consiste na proibição de oferecer vantagens aos estrangeiros simplesmente em razão de alegada maior dificuldade ou maior número de entraves com que os investidores se deparam ao atuar em uma economia e em um ambiente regulatório alienígena.

Em contrapartida, traz-se à baila o posicionamento doutrinário de Eduardo Teixeira ao discorrer sobre a igualdade entre capital estrangeiro e nacional no Brasil, com respaldo na Lei $\mathrm{n}^{\circ} 4.131 / 62$. O autor não considera que os dois se encontram na mesma posição, justamente em razão da "ausência de igualdade de oportunidades entre estes para uma competição justa" ${ }^{287}$, haja vista que o investidor estrangeiro no fundo sempre será mais competitivo, seja por sua maior facilidade no acesso à crédito no exterior, à grande capacidade de investimento, por suas marcas serem conhecidas ou por possuírem tecnologia de ponta. Entretanto, entende-se que, apesar de suas qualidades e competitividade internacional, a empresa estrangeira, quando adentra o território estrangeiro para investir, não detém as mesmas condições que um nacional investidor possuiria, e exemplo claro disso, é no que se refere às áreas de atuação reservadas apenas a investidor nacional, como as de segurança e desenvolvimento nacional.

${ }^{286}$ BERNASCONI-OSTERWALDER, Nathalie; BRAUCH, Martin Dietrich. Comparative Commentary to Brazil's Cooperation and Investment Facilitation Agreements (CIFAs) with Mozambique, Angola, Mexico, and Malawi. International Institute for Sustainable Development (IISD), p.1-16, September 2015. p. 10. Disponível em: <https://www.iisd.org/sites/default/files/publications/commentary-brazilcifas-acfis-mozambique-angola-mexico-malawi.pdf>. Acesso em: 15 set. 2015.

${ }^{287}$ SILVEIRA, Eduardo Teixeira. A disciplina jurídica do investimento estrangeiro no Brasil e no direito internacional. São Paulo: Editora Juarez de Oliveira, 2002. p. 70. 
O segundo conceito, o de nação mais favorecida, também está previsto em todos os acordos. Conforme disposto nos ACFIs, cada Parte concederá aos investidores da outra Parte e aos seus investimentos tratamento não menos favorável do que o concedido, em circunstâncias similares, aos investidores de um Estado não-Parte e aos seus investimentos. Novamente, ao efetuar análise dos acordos, nota-se que os ACFIs africanos também estendem a disposição da nação mais favorecida à fase de pré-estabelecimento, entretanto, distingue-se do tratamento nacional ao passo que a obrigação não deve observar a legislação doméstica dos Estados Anfitriões. Ademais, o instrumento firmado com o México permanece silente se se aplica apenas à fase de pré-estabelecimento, só à condução do investimento ou se às duas. Já a cláusula presente no tratado assinado com a Colômbia também ressalta as atividades englobadas pelo tratamento da nação mais favorecida em rol positivo, sendo estas circunstâncias as mesmas que a do tratamento nacional.

Entretanto, vale lembrar que, conforme pontua Andreas Ziegler (2008, p. 64-65):

\begin{abstract}
A cláusula de tratamento de nação mais favorecida, por si só implica obrigações internacionais e direitos não só entre os Estados contratantes do tratado internacional que o incorporem (muitas vezes referida como o 'tratado' básico), mas também entre estes Estados Contratantes e outros Estados (muitas vezes referidos como 'a terceira parte' do tratado) em virtude da existência de diferentes tratados internacionais. Portanto, uma cláusula de tratamento de nação mais favorecida não é só uma cláusula normal, mas também uma fonte de obrigações internacionais outras que aquelas explicitamente incluídas no tratado de base. Isso permite que as disposições de outros tratados sejam 'emprestadas' ou, possivelmente, a prática dos Estados-Membros relativas a terceiros ${ }^{288}$. (tradução da autora).
\end{abstract}

Nesse sentido, faz-se necessário muita cautela ao dispor essa obrigação de tratamento, visto que ela pode se estender a obrigações previstas em outros tratados que alguma das partes tenha pactuado ou vá pactuar no futuro com terceiros. Isso, pois, caso uma das partes do tratado-base se sinta prejudicada, poderá reclamar a existência de tratamento discriminatório tendo como paradigma o tratado da Parte que a discrimina como terceiro, o qual entende ser mais benéfico, podendo requerer a extensão de

\footnotetext{
${ }^{288}$ No original: “A most-favored nation treatment clause per se entails international obligations and rights not only among the Contracting States of the international treaty incorporating it (often referred to as 'the basic treaty'), but also among these Contracting States and other States (often referred to as 'the third-party treaty) by virtue of different international treaties. Therefore, a most-favored-nation treatment clause is not only a normal treaty clause, but also a source of international obligations other than those explicitly included in the basic treaty. It allows 'borrowing 'treaty provisions from other treaties or possibly State practice regarding third States". ZIEGLER, Andreas R. Most-favoured-nation (MFN) treatment. In: REINISCH, August (Org.). Standards of investment protection. Oxford: Oxford University Press, p. 59-86, 2008. p. 64-65.
} 
tratamento para tais previsões. Isso pode gerar um efeito em cascata, desencadeando insegurança jurídica às partes, diante da imprevisibilidade de, a qualquer momento, a Parte que se sentir prejudicada vir requerer a aplicação de tratamento conferido a terceira parte em outro instrumento relacional.

Precavendo-se disso, os ACFIs com o México e a Colômbia estabeleceram ressalvas de que os padrões de "tratamento nacional" e "nação mais favorecida" não devem ser interpretados como qualquer preferência de tratamento ou privilégio decorrente de disposições relativas à solução de controvérsias de investimentos previstos em acordo de investimentos ou acordo que contenha capítulo sobre investimentos. O intuito desse artigo consiste em evitar que ocorra a extensão procedimental da cláusula de resolução de conflitos contidas em outros tratados firmados pelo Estado Anfitrião, para que não se iniciem procedimentos arbitrais contra o Estado receptor de investimentos.

Foi o que se sucedeu no paradigmático caso Emilio Augustin Maffezini v. The Kingdom of Spain $^{289}$, citado anteriormente. Entretanto, apesar desta previsão nos ACFIs com México e Colômbia, não há ressalva quanto à importação de previsões substantivas. Ademais, o acordo com a Colômbia possui também normativa que ressalta a impossibilidade de se invocar na solução de controvérsias padrões de tratamento contidos em tratado de investimentos com terceiro país. Salienta-se que, de acordo com o ACFI brasileiro, a solução de controvérsias entre as Partes deve ser efetuada através da arbitragem Estado-Estado (e não investidor-Estado). Dessa forma, uma vez iniciado procedimento arbitral entre Estados, não se pode invocar o tratamento da nação mais favorecida alegando prejuízo, para que se possa beneficiar da arbitragem mista prevista em outro instrumento.

Importante ressaltar também a existência de outras exceções nos ACFIs. Todos os acordos estabelecem que o tratamento nacional e a nação mais favorecida não devem ser interpretados como obrigação de dar a outra parte benefício de tratamento, preferência ou privilégio resultante de qualquer acordo comercial internacional, organização de integração econômica regional, área de livre comércio, união aduaneira ou mercado comum, presente ou futuro, do qual uma das Partes seja membro ou a que venha aderir. Os ACFIs também não obrigam nenhuma Parte a conceder benefícios oriundos de tratados para se evitar a bitributação ou acordos internacionais de natureza fiscal já existentes de que cada Parte

\footnotetext{
${ }^{289}$ INTERNATIONAL CENTRE FOR SETTLEMENT OF INVESTMENT DISPUTES. Emilio Augustin Maffezini v. The Kingdom of Spain, ICSID Case n.ARB/97/7, Award, 13 Nov., 2000.
} 
seja membro ou que venha a aderir futuramente. O ACFI com o México complementa em seu art. $5, \S 3^{\circ}$, item "iii" que no caso de qualquer inconsistência do acordo com qualquer acordo ou convênio em matéria tributária, o último deve prevalecer. Ademais, nenhuma das disposições dos acordos deve ser interpretada de forma a impedir a adoção ou execução de qualquer medida destinada a garantir a imposição ou arrecadação equitativa ou efetiva de tributos, conforme previsto na legislação do Estado-Parte.

O ACFI com o Malaui assevera que o direito de revisão administrativa das decisões deve ser proporcional ao nível de desenvolvimento e os recursos disponíveis às Partes. Na opinião de Bernasconi-Osterwalder e Brauch, essa previsão parece permitir ao Estado a denegação do direito do investidor estrangeiro de rever decisões administrativas sob os auspícios do direito doméstico em certas circunstâncias. Entretanto, a redação não é bem clara quanto a isso ${ }^{290}$.

Há de se destacar que uma das mais notáveis diferenças entre os ACFIs e os demais TBIs é a ausência de previsão de padrões mínimos de tratamento ou do tratamento justo e equitativo e de proteção integral ${ }^{291}$. Os padrões internacionais mínimos de tratamento relacionam-se ao direito costumeiro internacional, pelo que o tratamento dispendido às Partes deve ser conforme o Direito Internacional. Este, normalmente aparece nos acordos de investimento conjuntamente com o padrão justo e equitativo.

A cláusula referente ao tratamento justo e equitativo pode aparecer nos tratados de investimento seja de forma direta, com referência explícita a esse padrão - opção tradicional adotada pelos Estados -, seja de forma a vincular esse standard de proteção aos princípios de Direito Internacional, ao mencionar, por exemplo que os instrumentos estarão "em conformidade com o Direito Internacional", o que acaba por limitar os tribunais arbitrais às diretrizes oriundas do Direito Internacional. Ressalta-se que nos anos 1990, os TBIs assinados pelo Brasil admitiam o padrão justo e equitativo, sendo vislumbrado destas duas maneiras. Entretanto, há outra possibilidade de menção a este padrão de proteção, qual seja por meio de determinados elementos que regulam a atuação do Estado Anfitrião. Dentre esses elementos, pode-se destacar a proibição de se denegar justiça, requisitos de

${ }^{290}$ BERNASCONI-OSTERWALDER, Nathalie; BRAUCH, Martin Dietrich. Comparative Commentary to Brazil's Cooperation and Investment Facilitation Agreements (CIFAs) with Mozambique, Angola, Mexico, and Malawi. International Institute for Sustainable Development (IISD), p.1-16, September 2015. p. 11. Disponível em: <https://www.iisd.org/sites/default/files/publications/commentary-brazilcifas-acfis-mozambique-angola-mexico-malawi.pdf $>$. Acesso em: 15 set. 2015.

${ }^{291}$ HAMILTON, Jonathan; GRANDO, Michelle, White \& Case. Brazil and the Future of Investment Protections. Latin Arbitration Law. Disponível em: <http://www.latinarbitrationlaw.com/brazil-and-thefuture-of-investment-protections/>. Acesso em: 15 set. 2015. 
transparência e boa-fé, comportamento consistente, previsível e estável, dentre outros. Por fim, outra possibilidade que se aventa é que o acordo seja silente quanto ao padrão de proteção justo e equitativo, o que não afasta a possibilidade de se invocar, com esteio no Direito internacional geral, este standard de proteção ${ }^{292}$.

Como já afirmado, nos ACFIs não existe a tutela direta do tratamento justo e equitativo. Porém, identifica-se em suas previsões cláusulas que rementem a alguns dos elementos que pautam a atuação do Estado receptor de investimentos. O primeiro deles corresponde ao insculpido no ACFI com a Colômbia, no art. $4^{\circ}, \S 2^{\circ}$ e $3^{\circ}$, em que "as Partes não denegarão justiça aos investimentos de investidores da outra Parte em procedimentos criminais, cíveis ou contenciosos administrativos"293 e outorgará tratamento aos investidores da outra Parte e a seus investimentos de acordo com o devido processo legal ${ }^{294}$. O ACFI com Angola possui dispositivo semelhante, em seu art. 11, § $7^{\circ}$, prevendo a concessão de tratamento nacional e da nação mais favorecida no que se refere ao acesso a tribunais de justiça e a agências administrativas e, também, à defesa de direitos de tais investidores.

Nesta toada, pode-se inferir que, mesmo não prevendo o padrão de tratamento justo e equitativo em seu texto legal, o fato de se prever o devido processo legal se coaduna à necessária atenção a esse padrão protetivo. Vale ressaltar que alguns laudos arbitrais fazem referência ao devido processo legal, como por exemplo, o caso Waste Management v. Mexico $^{295}$, em que o tribunal arbitral concluiu que o padrão de tratamento justo e equitativo abarca, dentre outros pontos, a falta de devido processo legal (due process). Segundo a decisão do tribunal arbitral no caso Waste Management v. Mexico:

O padrão mínimo de tratamento justo e equitativo é violado pela conduta imputável ao Estado e prejudicial ao reclamante se a conduta é arbitrária,

${ }^{292}$ UNITED NATIONS CONFERENCE ON TRADE AND DEVELOPMENT. Fair and equitable treatment. UNCTAD Series on issues in international investment agreements II. New York: Geneva: United Nations, 2012. p. 18; XAVIER JÚNIOR, Ely Caetano. Direito internacional dos investimentos e o Brasil: uma perspectiva a partir do padrão de tratamento justo e equitativo. 2014. 279 f. Dissertação (Mestrado em Direito) - Faculdade de Direito da Universidade Estadual do Rio de Janeiro, Rio de Janeiro, 2014. f. 196.

${ }^{293}$ BRASIL. Acordo e Cooperação e Facilitação de Investimentos entre a República Federativa do Brasil e o Governo da República da Colômbia. Bogotá, 09 de outubro de 2015. Disponível em: $<$ http://www.itamaraty.gov.br/images/ed_atosinter/20151009-ACFI-port2.pdf > . Acesso em: 10 out. 2015. art. $4^{\circ}, \S 2^{\circ}$.

${ }^{294}$ Ressalta-se que os TBIs dos EUA (2004 e 2012) preveem que o tratamento justo e equitativo inclui a obrigação de não denegar justiça criminal, civil ou procedimentos administrativos de acordo com o princípio do devido processo legal. Cf. DOLZER, Rudolph; SCHREUER, Christoph. Principles of international investment law. Oxford: Oxford University Press, 2008. p. 162.

295 INTERNATIONAL CENTRE FOR SETTLEMENT OF INVESTMENT DISPUTES. Waste Management Inc. v. United Mexican State (Number 2), ICSID Case n. ARB(AF)/98/2, Award, 30 Apr. 2004. 
extremamente injusta ou idiossincrática, é discriminatória e expõe o requerente a preconceito seccional ou racial, ou que envolva a falta do devido processo conducente a um resultado que ofende decoro judicial, como pode ser o caso de um fracasso manifesto de justiça natural em processos judiciais ou uma completa falta de transparência e franqueza em um processo administrativo ${ }^{296}$. (tradução da autora e grifos nossos).

Ademais, as cláusulas que visam evitar a denegação de justiça aos investidores da outra Parte têm se tornado frequentes nos novos padrões de acordo de promoção e proteção de investimentos, como naqueles celebrados pelos EUA, o que certamente serviu de inspiração para o ACFI brasileiro. Conforme previsto no capítulo de investimentos do acordo de livre comércio entre EUA e Chile, no art. 19.4, o padrão mínimo de "tratamento justo e equitativo, inclui a obrigação de não denegar justiça em procedimentos adjudicatórios criminais, civis e administrativos em consonância com o princípio do devido processo legal incorporado pelos principais sistemas legais do mundo; [...]”297.

Outro elemento estreito ao padrão justo e equitativo é a transparência, que se relaciona com o dever de publicidade e clareza no arcabouço legislativo e nos procedimentos administrativos do Estado Anfitrião ${ }^{298}$. Este elemento foi levantado no caso Waste Management v. Mexico, já citado anteriormente, bem como foi ressaltado no caso Metalclad v. Mexico ${ }^{299}$. Neste último, o tribunal arbitral decidiu que o México havia falhado em garantir quadro regulatório transparente e previsível para o planejamento e investimento da empresa Metalclad ${ }^{300}$.

Ressalta-se que o ACFI brasileiro também prevê esta obrigação, de forma que as leis, regulamentos, atos administrativos e até mesmo sentenças - no caso do ACFI com a Colômbia - referentes ao tema investimentos devem ser publicadas e disponibilizadas ao

${ }^{296}$ INTERNATIONAL CENTRE FOR SETTLEMENT OF INVESTMENT DISPUTES. Waste Management Inc. v. United Mexican State (Number 2), ICSID Case n. ARB(AF)/98/2, Award, 30 Apr. 2004, §98. No original: "the minimum standard of treatment of fair and equitable treatment is infringed by conduct attributable to the State and harmful to the claimant if the conduct is arbitrary, grossly unfair, unjust or idiosyncratic, is discriminatory and exposes the claimant to sectional or racial prejudice, or involves a lack of due process leading to an outcome which offends judicial propriety-as might be the case with a manifest failure of natural justice in judicial proceedings or a complete lack of transparency and candour in an administrative process".

${ }^{297}$ OFFICE OF THE UNITED STATES TRADE REPRESENTATIVE. Chile - United States Free Trade Agreement. Miami, 6 de junho de 2003. Disponível em: <https://ustr.gov/trade-agreements/free-tradeagreements/chile-fta/final-text>. Acesso em: 3 nov. 2015, art. 19.4.

${ }^{298}$ KOTERA, Akira. Regulatory transparency. In: MUCHLINSKI, Peter; ORTINO, Federico; SCHREUER, Christoph (Coord.).The Oxford Handbook of International Investment Law. Oxford: Oxford University Press, p. 617-636, 2008.

299 INTERNATIONAL CENTRE FOR SETTLEMENT OF INVESTMENT DISPUTES. Metalclad Corporation v. The United Mexican States, ICSID Case n. ARB(AF)/97/1, Award, 30 Aug. 2000.

${ }^{300}$ Ibid., $\$ 99$. 
público, ação que se torna essencial para que se alcance maior previsibilidade e estabilidade nas relações entre as Partes.

Desse modo, pode-se inferir que que não existe, de fato, uma cláusula geral padrão nos ACFIs brasileiros, contudo, identificam-se padrões mínimo, fixos e independentes do tratamento nacional e nação mais favorecida, consubstanciados em elementos concretos que devem pautar a ação do Estado Anfitrião.

Ainda, o ACFI com Angola estipula que cada Parte poderá, conforme o seu direito interno, prever formalidades especiais ligadas às atividades de investimento dos investidores da outra Parte em seu território, desde que tais formalidades especiais não prejudiquem a substância dos direitos de tais investidores e o princípio da não discriminação.

Por fim, há que se destacar a existência de um último padrão de tratamento presente nos ACFIs. No ACFI com Angola, no art. $8^{\circ}$, vislumbra-se a existência de uma umbrela clause, a qual prevê que cada parte deve observar e respeitar as obrigações assumidas expressamente em relação aos investimentos dos investidores da outra Parte ${ }^{301}$. Ou seja, de acordo com esta previsão, permite-se que investidores que estejam protegidos por esse acordo possam submeter aos mecanismos de solução de controvérsias não apenas uma questão advinda da violação de compromissos estabelecidos no ACFI, mas também violação de outros compromissos presentes em outros instrumentos. Assim, esta previsão poderá, potencialmente, permitir, por exemplo, que Angola conteste o Brasil por quebra de contrato sob o respaldo do ACFI, ou vice-versa.

Nesse ínterim, apesar de este ponto não ser abordado no presente trabalho, ressalta-se que a grande crítica a essa cláusula reside na possibilidade dela poder substituir (e em quais circunstâncias) os acordos de investimento por meio das previsões contratuais entre o Estado Anfitrião e o investidor, sob a proteção do tratado ${ }^{302}$.

e) Transferências

A garantia da livre transferência de ativos trata-se de uma das disposições mais protetivas no âmbito dos APPRIs, haja vista que assegura o deslocamento de lucros,

${ }^{301}$ DOLZER, Rudolf; SCHREUER, Christoph. Principles of international investment law. Oxford: Oxford University Press, 2008. p. 153.

${ }^{302}$ Ibid. 
repatriamento de capitais e outros pagamentos decorrentes da operacionalização dos investimentos em território estrangeiro, mesmo diante de medidas nacionais restritivas a esse livre fluxo internacional, resultantes de políticas nacionais desenvolvimentistas ou de controle de câmbio.

Desse modo, diversos TBIs optaram por incluir em seu bojo cláusulas que garantissem o direito de realizar transferências em relação a seus investimentos sem atraso injustificado, em moeda livremente conversível e em taxa de câmbio específica ${ }^{303}$.

No acordo brasileiro, esse padrão de proteção está contido na cláusula de transferências, que estabelece a livre circulação de recursos relacionados ao investimento, sem que haja demora, em moeda livremente conversível ou de acordo com a taxa de câmbio em vigor na data da transferência. Além disso, os acordos especificam de forma detalhada do que se tratam as transferências, para que as Partes melhor compreendam quais ativos podem ser transferidos, como se pode notar, de forma mais completa, por meio do art. $9^{\circ}, \S 1^{\circ}$, do ACFI com a Colômbia:

1. As Partes, sem demora injustificada e após o cumprimento dos requisitos estabelecidos em seu ordenamento jurídico interno, permitirão a livre transferência dos fundos relacionados com o investimento, a saber:

(a) a contribuição inicial ao capital inicial ou qualquer adição deste em relação à manutenção ou expansão deste tipo de investimento; (b) os rendimentos diretamente relacionados com o investimento; (c) as receitas provenientes da venda ou liquidação total ou parcial do investimento; (d) os salários e demais remunerações auferidos pelo pessoal contratado no exterior relativos a um investimento; (e) os pagamentos de qualquer empréstimo, incluindo os juros sobre este, diretamente relacionados com o investimento, e (f) o montante da indenização ou o valor dos recursos obtidos com a venda no mercado de títulos recebidos como indenização ${ }^{304}$.

Nesse diapasão, os ACFIs com Angola, Moçambique, México e Malaui são mais explícitos ao apontarem que as transferências incluirão o montante da indenização em caso de expropriação ou desapropriação, sendo que o acordo com o México também inclui a indenização em caso de compensação por perdas ${ }^{305}$. Em todos os casos, quando a

${ }^{303}$ UNITED NATIONS CONFERENCE ON TRADE AND DEVELOPMENT. Bilateral Investment Treaties 1995-2006: Trends in Investment Rulemaking New York and Geneva: United Nations, 2007. p. 56.

${ }^{304}$ BRASIL. Acordo e Cooperação e Facilitação de Investimentos entre a República Federativa do Brasil e o Governo da República da Colômbia. Bogotá, 09 de outubro de 2015. Disponível em: $<$ http://www.itamaraty.gov.br/images/ed_atosinter/20151009-ACFI-port2.pdf $>$. Acesso em: 15 out. 2015. art. $9^{\circ}, \S 1$.

${ }^{305}$ Segundo o art. $9^{\circ}, \S 1^{\circ}$, letra "e", do ACFI com o México "o montante da indenização, em caso de expropriação, compensação por perdas ou utilização temporária do investimento de um investidor da outra Parte pela Autoridade Pública do Estado anfitrião. [...]”. Cf. BRASIL. Acordo e Cooperação e Facilitação de Investimentos entre a República Federativa do Brasil e os Estados Unidos do México. 
indenização é paga em títulos da dívida pública, os investidores poderão transferir o valor dos recursos obtidos com a venda desses títulos no mercado.

Não obstante, os acordos também contêm exceções à livre circulação de capitais, atribuindo que estas devem ser realizadas através de aplicação equitativa, nãodiscriminatória e por meio da boa-fé de suas leis. Desse modo, uma Parte poderá impedir ou retardar a transferência nas seguintes situações: (i) falência, insolvência ou proteção dos direitos dos credores; (ii) infrações penais ${ }^{306}$ ou administrativas; (iii) garantia de cumprimento de decisões de órgãos jurisdicionais e administrativos. O ACFI com a Colômbia acrescenta ainda, no art. $9^{\circ}, \S 3^{\circ}$, letra “c", a hipótese de restrição para o cumprimento de obrigações trabalhistas ou tributárias. Já o ACFI com o México trata, também, no art. $9^{\circ}, \S 2^{\circ}$, letra “c", da situação em que há a aplicação de relatórios de transferências de divisas ou de outros instrumentos monetários.

Outrossim, importante destacar que os ACFIs preveem salvaguarda em caso de graves dificuldades na balança de pagamento e nas finanças externas ou na ameaça destas, pelo que diante dessas circunstâncias, o Estado poderá adotar ou manter restrições sobre pagamentos e transferências para as transações envolvendo os investimentos no âmbito dos acordos, desde que não sejam discriminatórias e evitem danos desnecessários aos interesses econômicos do investidor ${ }^{307}$. O ACFI com a Colômbia acrescenta, em seu art. $9^{\circ}$, $\S 4^{\circ}$, letra "b", o direito de restrição à livre transferência quando, por circunstâncias especiais, os movimentos de capital gerem ou ameacem gerar graves complicações ao manejo macroeconômico, em particular, às políticas monetárias ou cambiais.

De acordo com o previsto no art. $12, \S 4^{\circ}$, (ii) e (iii) do ACFI com o Malaui, estas medidas deverão ser temporárias e reduzidas progressivamente conforme ocorrer melhora na situação de grave dificuldade enfrentada. Além disso, não se deve afetar o direito de uma das Partes em tomar medidas regulatórias relacionadas com a balança de pagamentos durante uma crise de balança de pagamento, nem os direitos e obrigações dos membros no Fundo Monetário Internacional (nos termos do Acordo relativo ao Fundo), incluindo a aplicação de medidas cambiais em conformidade com o previsto nos acordos.

\footnotetext{
Brasília, 26 de maio de $2015 . \quad$ Disponível $<$ http://investmentpolicyhub.unctad.org/Download/TreatyFile/3458>. Acesso em: 30 set 2015. art. $9^{\circ}, \S$ $1^{\circ}$, letra "e".

${ }^{306}$ No ACFI com Malaui especifica-se "infrações penais e a recuperação do produto de crime".

307 KOLO, Abba; Wälde, Thomas. Capital transfer restrictions under modern investment treaties. In: REINISCH, August (Org.). Standards of investment protection. Oxford: Oxford University Press, p. 205-243, 2008.
} 
Ressalta-se que o direito de garantia de obstrução da livre transferência de capitais em se tratando de crises financeiras e cambiais constituía grande temor nos anos 1990, sendo, inclusive, um dos aspectos de resistência parlamentar para a ratificação dos TBIs brasileiros no Congresso. Com as previsões contidas nos ACFIs, tem-se que esta preocupação foi sanada, haja vista ser expresso o dispositivo que permite esse tipo de restrição, desde que temporária e não discriminatória.

f) Expropriação

Cláusulas de expropriação são previsões que reconhecem o direito de o Estado Anfitrião expropriar ou nacionalizar propriedade estrangeira privada, se atendidas certas condições para tanto. Segundo a UNCTAD, a maioria das cláusulas nos APPRIs prevê os termos expropriação e nacionalização, evitando defini-los ou distingui-los um do outro. No ACFI brasileiro, prevê-se o instituto da expropriação, entretanto, como não há definição explícita, o sentido utilizado é o de desapropriação para o direito brasileiro ${ }^{308}$, que é baseado em procedimento administrativo e realizado mediante indenização prévia, justa e em dinheiro ${ }^{309}$.

A estrutura implementada nos ACFIs é bastante similar aos demais APPRIs, especificando que somente haverá desapropriação quando justificada por utilidade pública ou interesse social, de forma não discriminatória, mediante o pagamento de indenização justa, adequada e efetiva, de acordo com o devido processo legal e em conformidade com suas leis e regulamentos. Ademais, a indenização deverá ser pronta ou sem demora indevida, ser equivalente ao valor justo de mercado do investimento expropriado

${ }^{308}$ Vide art. $5^{\circ}$, inciso XXIV; art. 182, $\S 4^{\circ}$ e art. 184 da CF brasileira. De forma mais particular, para o ordenamento jurídico brasileiro desapropriação corresponde a procedimento administrativo pelo qual o Poder Público ou seus delegados, fundado na necessidade pública, utilidade pública ou interesse social, mediante indenização prévia, justa e pagável em dinheiro (salvo no caso de imóveis urbanos ou rurais para fins de reforma agrária, em que a indenização se dará através de títulos da dívida pública), impõe ao proprietário a perda de um bem móvel ou imóvel. Já a expropriação, prevista no art. 243 da Constituição Federal trata-se de instituto que se equipara ao confisco, por não garantir ao expropriado o direito à indenização. Neste, o indivíduo perde o seu direito à propriedade das glebas nas quais estejam localizadas o cultivo de plantas psicotrópicas ilícitas. DI PIETRO, Maria Sylvia Zanella. Direito administrativo. 27. ed. São Paulo: Atlas, 2014. p. 166-170. MELLO, Celso Antônio Bandeira de. Curso de direito administrativo. 27. ed. São Paulo: Malheiros, 2010. p. 865-866.

${ }^{309}$ DI PIETRO, Maria Sylvia Zanella. Direito administrativo. 27. ed. São Paulo: Atlas, 2014. p. 180. 
imediatamente antes que a desapropriação seja efetuada ou antes que sua iminência seja de conhecimento público, o que ocorra antes (“data da desapropriação") $)^{310}$.

O termo empregado nos ACFIs trata-se apenas de expropriação, de forma genérica, sem distingui-la, se direta ou indireta ${ }^{311}$, assim como o fazem diversos outros acordos de promoção e proteção de investimentos ${ }^{312}$. Devido à ausência de especificidade, há margem para se considerar que o conceito engloba ambas ${ }^{313}$. Contudo, ressalta-se que no passado, o governo brasileiro deixou bem clara sua intenção de cobrir apenas expropriações diretas em seus antigos tratados, sendo resistente à expropriação indireta.

Faz-se necessário ressaltar que quanto ao cálculo da compensação, o padrão contido nesse acordo determina que a indenização deverá ser liquidável ${ }^{314}$ (no sentido de livremente pagável, em inglês, payable) e livremente transferível. Se o valor justo de mercado for calculado em moeda internacionalmente conversível, ou seja, amplamente aceita em outro país para realizar pagamentos de transações internacionais (e.g. dólar, libra, euro, iene ou franco suíço), a indenização paga não poderá ser inferior ao valor justo de mercado na data da valoração mais os juros comerciais fixados com base em critérios de mercado para a referida moeda, acumulados desde a data da valoração até a data do pagamento, de acordo com a legislação do Estado Anfitrião.

Caso o valor justo de mercado seja calculado em moeda que não seja livremente conversível, o pagamento da indenização não poderá ser inferior ao valor justo de mercado na data da valoração mais os juros comerciais fixados com base em critérios de mercado para a referida moeda, acumulados desde a data da valoração até a data do pagamento, de acordo com a legislação do Estado Anfitrião.

Como já exposto, os ACFIs simplesmente preveem que a indenização deverá ser imediata, líquida e transferível, sem fazer qualquer ressalva a essas disposições

${ }^{310} \mathrm{O}$ ACFI com Moçambique e com México determinam ainda que a indenização não deve refletir uma alteração negativa no valor de mercado em função de conhecimento da intenção de expropriar com antecedência à data da expropriação.

311 Conforme já exposto anteriormente, a terminologia para expropriação indireta ainda não é uniforme, porém, para fins desse trabalho, expropriação indireta circunscreve-se àqueles casos em que, em razão de medidas regulatórias do Estado Anfitrião, reduz-se significativamente o valor do investimento.

312 REINISCH, August. Expropriation. In: MUCHLINSKI, Peter; ORTINO, Federico; SCHREUER, Christoph (Coord.).The Oxford Handbook of International Investment Law. Oxford: Oxford University Press, p.407-458, 2008, p. 422.

${ }^{313}$ BRAUCH, Martin Dietrich. The Brazil-Mozambique and Brasil-Angola cooperation and investment facilitation agreements (CIFAs): a descriptive overview. Investment Treaty News. International Institute for Sustainable Development, 21 mai 2015. Disponível em: $<$ https://www.iisd.org/itn/2015/05/21/the-brazil-mozambique-and-brazil-angola-cooperation-andinvestment-facilitation-agreements-cifas-a-descriptive-overview/>. Acesso em: 18 set. 2015.

314 O termo "liquidável" está contido nos ACFIs com Moçambique e Malaui. 
constitucionais brasileiras. Ocorre que, na década de 1990, esse foi um ponto sensível na análise do legislativo para a aprovação dos TBIs brasileiros, os quais determinavam as mesmas disposições, sem impor quaisquer ressalvas. Estas são importantes haja vista que há dois casos na Constituição Federal, nos art. $182, \S 4^{\circ}$ e art. 184, que restringem o direito legal de receber pagamentos líquidos e imediatos: (i) quando se tratar de solo urbano não edificado, subutilizado ou não utilizado e (ii) quando houver desapropriação por interesse social, para fins de reforma agrária de imóvel rural. Nesses casos, o texto constitucional estabelece que as indenizações deverão ser realizadas através de títulos da dívida pública que apesar de liquidáveis, não são líquidos.

Entretanto, diferentemente dos textos dos TBIs brasileiros dos anos 1990, os ACFIs estabelecem, como já exposto anteriormente, que pode ser considerada como transferência o valor da indenização, em caso de expropriação ou desapropriação e, quando a indenização for paga em títulos da dívida, o investidor poderá transferir ao exterior o valor auferido com a alienação dos títulos.

Nesse diapasão, constata-se que no acordo brasileiro é válido o pagamento em títulos da dívida no caso de expropriação, disposição que se encontra em consonância com as exceções previstas na Constituição Federal. Contudo, constata-se que, ao se analisar os padrões adotados internacionalmente, essa disposição prevê direito de indenização inferior àquele estabelecido pela Fórmula Hull, standard de proteção comumente utilizado pelos países exportadores de capital, que estabelece que a indenização deve ser necessariamente "pronta, adequada e efetiva".

O ACFI com a Colômbia inova e complementa em seu texto, no art. $6^{\circ}, \S 6$, que: "as Partes poderão estabelecer monopólios estatais ou reservar atividades estratégicas que privem um investidor de desenvolver uma atividade econômica, desde que seja por motivos de utilidade pública ou interesse social”. Nesse caso, resta claro que investimentos estrangeiros em áreas que podem ser consideradas posteriormente estratégicas para algum dos Estados Partes, como por exemplo, aquelas relacionadas à segurança nacional, energia ou comunicação, podem ser alvo de expropriação por parte do Estado Anfitrião, desde que cumpram com os requisitos gerais estabelecidos.

Ademais, um problema que surge é que, nos termos da Lei de Terras angolana (Lei $n^{\circ}$ 09/04), para os eventuais litígios que possam surgir sobre a transmissão ou a constituição de direitos fundiários é possível a submissão à arbitragem. Nesse sentido, salienta-se que questões sobre expropriação ou o valor da compensação do investimento 
expropriado poderão ser encaminhadas ao tribunal arbitral de acordo com a lei de Angola. Esse ponto se torna delicado ao passo que, da ótica do direito brasileiro, esta discussão é geralmente realizada perante os tribunais estatais, bem como o ACFI nada especifica sobre isso, mesmo prevendo a submissão às leis internas dos Estados Partes.

g) Compensação por Perdas

As compensações por perdas são aquelas estabelecidas em decorrência de guerras, insurreições, revoltas, rebeliões ou outros tipos de distúrbio atribuível à humanidade. De forma similar ao TBI americano ${ }^{315}$, nos ACFIs está contida esta previsão, pelo que se designa que os investidores que incorram em perdas devido a guerra, outro conflito armado ou acontecimento similar gozarão de restituição, indenização, compensação ou outro tipo de solução regida por tratamento não menos favorável que o Estado Anfitrião conceda aos seus investidores nacionais ou àqueles de um terceiro Estado. Salienta-se que os ACFIs com Angola e Moçambique especificam que a compensação deve ser realizada em moeda livremente conversível, o que é silente nos outros acordos.

Os ACFIs com Angola, México e Moçambique preveem ainda que as perdas decorrentes das situações contempladas e que ensejam indenização devem ser aquelas resultantes de requisição do investimento (no todo ou em parte) ou a destruição do investimento (no todo ou em parte) pelas forças ou autoridades governamentais. Os investidores, portanto, deverão receber a restituição, indenização ou compensação sem demora, de forma adequada e efetiva.

Ademais, como já citado nas disposições sobre transferências, o art. $9^{\circ}, \S 1^{\circ}$, letra "e" do ACFI com o México dispõe que as transferências também englobam indenização em caso de compensação por perdas, especificando que quando o montante da indenização for pago em títulos da dívida pública, os valores poderão ser transferidos com a venda desses títulos no mercado. Assim, infere-se através desse artigo que as compensações por perdas também podem ser pagas por meio de títulos da dívida pública.

h) Transparência

${ }^{315}$ HAMILTON, Jonathan; GRANDO, Michelle, White \& Case. Brazil and the Future of Investment Protections. Latin Arbitration Law. Disponível em: $<$ http://www.latinarbitrationlaw.com/brazil-and-thefuture-of-investment-protections/>. Acesso em: 15 set. 2015. 
A obrigação de transparência tem adquirido cada vez mais espaço na redação dos acordos de promoção e proteção recíproca de investimentos. Sua redação tem sido inserida, principalmente, nas previsões referentes à promoção de investimentos, tendo em vista que o dever de transparência envolve tanto a troca de informações entre as Partes Contratantes sobre as oportunidades de investimentos em seus territórios, quanto o intercâmbio de informações no que tange a leis, regulamentos e práticas administrativas ${ }^{316}$.

Nos ACFIs, as diretrizes sobre o tema focam na publicidade de leis e regulamentos que afetem os investimentos, bem como preveem que as Partes envidem esforços e deem notoriedade imediata aos procedimentos administrativos internos (de preferência pela via eletrônica), como é o caso de qualificações, licenças e certificações, que os investidores terão de enfrentar uma vez que optem por investir no Estado Anfitrião. Além disso, as Partes deverão se esforçar para permitir oportunidade razoável de manifestação aos interessados (setor privado e sociedade civil) sobre as medidas $\operatorname{propostas}^{317}$.

No caso do ACFI com a Colômbia, no art. $8^{\circ}, \S 2$, a redação destaca a garantia de publicidade de sentenças de aplicação geral. Ademais, o mesmo instrumento prevê no $\S 5$ uma inovação em relação aos outros, ao determinar que as Partes promoverão a transparência em seus processos legislativos, regulatórios, administrativos e judiciais e oferecerão procedimentos de revisão ou apelação para assegurar que operem em consonância com a legislação interna aplicável de cada Contratante.

Outrossim, há previsão que ressalta a necessidade de dar publicidade ao acordo aos respectivos agentes financeiros, públicos e privados, responsáveis pela avaliação técnica de riscos e aprovação de financiamentos, créditos, garantias e seguros afins. O acesso à informação para esses órgãos se torna de fundamental importância, visto que são eles os responsáveis por alavancar essas empresas ao exterior por meio de facilidades creditícias.

316 UNITED NATIONS CONFERENCE ON TRADE AND DEVELOPMENT. Bilateral investment treaties 1995-2006: trends in investment rulemaking. New York; Geneva: United Nations, 2007. p. 76 77.

${ }^{317}$ BRASIL. Acordo de Cooperação e Facilitação de Investimentos entre o Governo da República Federativa do Brasil e o Governo da República de Angola. Luanda, $1^{\circ}$ de abril de 2015. Disponível em: $<$ http://www.itamaraty.gov.br/index.php?option=com_content\&view=article\&id=8520:acordo-brasilangola-de-cooperacao-e-facilitacao-de-investimentos-acfi-luanda-1-de-abril-de-

2015\&catid $=42 \&$ Itemid $=280 \&$ lang=pt-BR $>$. Acesso em: 15 set. 2015. art. 13, $\S 2$ e 3. 
Vale ressaltar que a busca por maior transparência e publicidade dos instrumentos legislativos e administrativos do Estado Anfitrião era uma das demandas dos investidores brasileiros no exterior, que chegavam ao país e enfrentavam dificuldades no acesso às informações jurídicas e burocráticas necessárias à implementação e condução de seus investimentos $^{318}$. Esse dispositivo visa a facilitar a atuação dos investidores, pois, uma vez públicas as informações, isso fará com que haja um ambiente de investimentos mais previsível a todos os interessados.

i) Exceções: Medidas Tributárias, Medidas Prudenciais e Exceções de Segurança

A principal razão para a instituição de uma exceção é eximir a parte contratante das obrigações contidas nos APPRIs em situações em que a conformidade com estes dispositivos seria incompatível com os objetivos de sua legislação nacional. Desse modo, as exceções garantem que as obrigações dos acordos não impeçam a Parte de aplicar suas diretrizes domésticas para proteger seus valores fundamentais. Nesse diapasão, destaca-se que a adoção de exceções tem sido bastante utilizada nos últimos anos. No contexto dos ACFIs, salienta-se que apenas os acordos com México e Colômbia possuem as três previsões relativas a medidas tributárias, prudenciais e aquelas referentes a exceções de segurança; já o ACFI com o Malaui detém apenas a primeira.

No que tange à cláusula sobre medidas tributárias, destaca-se que esta tem como escopo em ambos os acordos estipular que os ACFIs não devem ser interpretados como uma obrigação de uma Parte com relação a outra, em relação a seus investimentos, de conceder benefício resultante de tratado para se evitar a dupla tributação, atual ou futuro, em que uma das Partes é parte ou venha a tornar-se parte. Ademais, a exceção reside na disposição de que nenhum dispositivo presente nos ACFIs deve ser analisado como impeditivo na adoção ou aplicação de norma que vise à imposição ou cobrança tributária de acordo com a legislação interna das Partes. Ainda, o ACFI com o México faz a ressalva de que isso é válido desde que esta medida não consista em mecanismo discriminatório arbitrário ou injustificável ou em uma restrição disfarçada.

${ }^{318}$ SOUZA, Renato Rezende de Campos. Cooperation and Facilitation Investment Agreement - CFIA. [apresentação de slides no World Investment Forum]. [s.1.], mai 2015. Disponível em: <http://unctadworldinvestmentforum.org/wp-content/uploads/2015/03/Brazil_side-event-Wednesday_modelagreements.pdf>. Acesso em: 15 set. 2015. 
O setor financeiro trata-se de setor relevante para toda a economia de um país, sendo frequentemente bastante regulado. Nesse sentido, os ACFIs estabelecem que não se impedirá que uma das Partes adote ou mantenha medidas que digam respeito ao setor financeiro por razões prudenciais, o que inclui as mrfifsd referentes à proteção dos investidores, dos depositantes, dos segurados ou de pessoas com as quais um prestador de serviços financeiros tenha contraído obrigação fiduciária, ou para garantir a integridade do sistema financeiro. Contudo, caso as regulações internas não estejam em consonância com as disposições dos acordos, estas não poderão ser utilizadas como meio de contornar compromissos ou obrigações contraídas pela Parte sob o amparo do referido $\mathrm{ACFI}^{319}$. Logo, tem-se que o principal escopo dessa cláusula é, portanto, assegurar a estabilidade e a integridade do sistema financeiro.

Finalmente, de acordo com a cláusula de exceção de segurança, nenhuma previsão do acordo deverá ser interpretada para impedir que uma Parte detenha medidas que visem a manutenção da segurança nacional e da ordem pública ou a aplicação de disposições de seu direito penal. Nesse aspecto, a UNCTAD salienta que, normalmente, os TBIs evitam incluir a definição do que seja entendido como segurança nacional ou ordem pública, ao passo que, ao deixar esses termos em aberto as partes desejam resguardar sua flexibilidade em determinar, caso a caso, se se está enfrentando situação em que tanto a segurança nacional quanto a ordem pública estejam ameaçadas ${ }^{320}$. Esse é o caso dos ACFIs, que não apresentam definições quanto a esses dois conceitos. Porém, ao se analisar o texto do acordo com a Colômbia, identifica-se que este provê, no art. 12, mais especificações que complementam a situação avaliada:

Nenhuma disposição deste Acordo será interpretada no sentido de impedir que uma Parte adote ou mantenha medidas destinadas a preservar a ordem pública, o cumprimento de suas obrigações para a manutenção ou restauração da paz ou

${ }^{319}$ Ressalta-se que essas previsões se assemelham às do TBI entre Japão e Vietnã, de 2003, em seu art. 17: "1. Notwithstanding any other provisions of this Agreement, a Contracting Party may adopt or maintain prudential measures with respect to financial services, including measures for the protection of investors, depositors, policy holders or persons to whom a fiduciary duty is owed by an enterprise providing financial services, or to ensure the integrity and stability of its financial system. 2. In cases where a Contracting Party takes any measure, pursuant to paragraph 1 above, that does not conform with the obligations of the provisions of this Agreement, that Contracting Party shall not use such measure as a means of avoiding its obligations. [...]”. Cf. JAPÃO. Agreement Between Japan and the Socialist Republic of Viet Nam for the Liberalization, Promotion and Protection of Investment, Tóquio, 14 de novembro de 2003. Disponível em: <http://www.mofa.go.jp/region/asia-paci/vietnam/agree0311.pdf $>$. Acesso em: 3 nov. 2015. art. 17.

${ }^{320}$ UNITED NATIONS CONFERENCE ON TRADE AND DEVELOPMENT. Bilateral investment treaties 1995-2006: trends in investment rulemaking. New York and Geneva: United Nations, 2007. p. 83-84. 
segurança internacionais, a proteção de seus próprios interesses essenciais de segurança ou a aplicação de disposições do seu direito penal ${ }^{321}$.

A adoção de medidas para o cumprimento de obrigações para a manutenção ou restauração da paz ou segurança internacionais e da previsão de proteção de seus próprios interesses essenciais de segurança trata-se de matéria já abordada, por exemplo, em todos os TBIs dos EUA ${ }^{322}$ e no TBI canadense de 2004. De mesmo modo, a ausência de definições remete ao condão da discricionariedade das partes em determinar se uma medida é de fato necessária para cumprir obrigações relativas à manutenção da paz ou segurança internacionais ou à proteção dos interesses de segurança nacional. Esta flexibilidade tem consequências jurídicas importantes, uma vez que impediria que terceiros - como por exemplo, um tribunal arbitral - realizassem avaliação independente, para determinar se a medida tomada pelas autoridades do país anfitrião era realmente necessária.

Entretanto, esse não parece ser o caso, visto que os acordos estipulam que as medidas, bem como as decisões respaldadas em leis de matéria de segurança nacional ou ordem pública, que a qualquer momento pró́bam ou restrinjam um investimento, não estão sujeitas ao mecanismo de solução de controvérsias estabelecido nos ACFIs.

j) Responsabilidade Social Corporativa

Nos últimos anos, os APPRIs têm adquirido uma dimensão voltada à garantia de investimentos responsáveis e que contribuam de forma positiva com a comunidade local residente no Estado hospedeiro. As cláusulas relativas a padrões de responsabilidade social corporativa concentram-se nas operações das empresas transnacionais no Estado receptor de investimentos, de forma a tentar assegurar uma conduta mais responsável em território estrangeiro.

${ }^{321}$ BRASIL. Acordo e Cooperação e Facilitação de Investimentos entre a República Federativa do Brasil e o Governo da República da Colômbia. Bogotá, 09 de outubro de 2015. Disponível em: $<$ http://www.itamaraty.gov.br/images/ed_atosinter/20151009-ACFI-port2.pdf > . Acesso em: 15 out. 2015, art.12.

${ }^{322}$ Como exemplo, pode-se citar o TBI entre EUA e Moçambique, que enuncia em seu art. XVI que: "This Treaty shall not preclude a Party from applying measures that it considers necessary for the fulfilment of its obligations with respect to the maintenance or restoration of international peace or security, or the protection of its own essential security interests. [...]". Cf. UNITED NATIONS CONFERENCE ON TRADE AND DEVELOPMENT. Bilateral investment treaties 1995-2006: trends in investment rulemaking. New York and Geneva: United Nations, 2007. p. 85. 
Ressalta-se que as preocupações iniciais diziam respeito à responsabilidade dos investidores quanto a direitos trabalhistas, sendo que, recentemente, essas garantias têm evoluído e englobado também obrigações relativas a direitos humanos, questões ambientais, e, até mesmo, em alguns casos tem se incorporado obrigações anticorrupção, acrescentadas pela The UN Global Compact ${ }^{323}$.

Em se tratando dos ACFIs estabelece-se que os investidores estrangeiros devem esforçar-se em implementar o mais alto nível possível de contribuições para o alcance do desenvolvimento sustentável do Estado Anfitrião e a comunidade local, tomando como referência os princípios voluntários e padrões estabelecidos no próprio acordo. Nessa esteira, os acordos preveem um rol exemplificativo de princípios e padrões voluntários a serem seguidos pelas empresas, contidos no Anexo II dos acordos com Angola e Moçambique e no corpo dos acordos com Colômbia, Malaui e México, os quais devem ser coerentes com a legislação do Estado receptor.

Em todos os acordos as diretrizes seguem o mesmo padrão e suscitam que os investimentos e investidores devem: ser guiados pela máxima da proteção ao meio ambiente; promover o desenvolvimento sustentável; respeitar os direitos humanos; reforçar as capacidades locais e a formação de capital humano; abster-se procurar ou aceitar exceções não previstas nas legislações locais relativas a saúde, meio ambiente, trabalho, etc.; promover os princípios e práticas de boa governança, privar-se de ingerências no sistema político local, dentre outras.

Além dessas previsões, importante destacar que o ACFI com a Colômbia estabelece separadamente, no art. 14, que cada parte empreenderá esforços para prevenir e combater a corrupção, a lavagem de ativos e o financiamento ao terrorismo em relação a matérias cobertas por esse acordo, em consonância com as leis e regulamentos das Partes. Ademais, estipula-se que não há obrigações dispostas no acordo que obrigará as partes a proteger investimentos realizados com dinheiro ou ativos de origem ilícita ou investimentos maculados por atos de corrupção.

Notável, portanto, que essas obrigações demonstram a preocupação de ambos os Estados com o envolvimento das Partes no financiamento de atividades ilícitas e práticas que visam à violência. Salienta-se que principalmente a cláusula que combate a corrupção

${ }^{323}$ MUCHLINSKI, Peter. Corporate Social Responsibility. In: MUCHLINSKI, Peter; ORTINO, Federico; SCHREUER, Christoph (Coord.).The Oxford Handbook of International Investment Law. Oxford: Oxford University Press, p. 637-687, 2008. p. 645. 
acompanha uma tendência nos padrões de proteção dos APPRIs mais atuais, como é o caso do novo TBI da Índia (2015), que também contém dispositivos contra corrupção, apesar destes serem mais detalhados que os ACFIs brasileiros ${ }^{324}$.

Outra particularidade do ACFI com a Colômbia é o art. $15, \S 1$, que prevê que nada disposto no texto do acordo será interpretado como impedimento para que uma Parte adote, mantenha ou faça cumprir medida que considere apropriada para garantir que os investimentos em seu território sejam realizados em conformidade com a legislação trabalhista, ambiental, de saúde ou segurança nacionais dessa Parte, desde que não discriminatórias, injustificáveis ou constituam restrição disfarçada.

O propósito desse artigo é enunciado em seu $\S 2^{\circ}$, que esclarece não ser apropriado estimular o investimento diminuindo os padrões estabelecidos por suas regulações, logo, as Partes se comprometem a não modificar as legislações internas concernentes a esses temas para o fomento de investimentos estrangeiros, caso isso implique na redução do padrão de proteção nacional estabelecido. Caso uma das partes proponha esse tipo de incentivo, a outra parte poderá requerer consultas para que possam discutir e trocar informações sobre o assunto.

\subsection{CONSIDERAÇÕES FINAIS}

Desse modo, realizada a análise dos ACFIs, desde sua formulação até sua estrutura clausular, conclui-se que o novo acordo de investimentos do Brasil recoloca na agenda comercial brasileira os acordos de investimento, reconhecendo a importância de proteger os investimentos de empresas brasileiras no exterior. Este novo standard de proteção busca seguir novas tendências que pairam sobre os APPRIs do século XXI, como menções à cooperação, desenvolvimento sustentável, o reforço à autonomia legislativa dos Estados e a reponsabilidade social corporativa, ao mesmo tempo em que continua a carregar alguns pontos históricos da resistência brasileira, como a oposição à expropriação indireta e à arbitragem de investimentos.

${ }^{324}$ BERNASCONI-OSTERWALDER, Nathalie; BRAUCH, Martin Dietrich. Comparative Commentary to Brazil's Cooperation and Investment Facilitation Agreements (CIFAs) with Mozambique, Angola, Mexico, and Malawi. International Institute for Sustainable Development (IISD), p.1-16, September 2015, p.9. Disponível em: <https://www.iisd.org/sites/default/files/publications/commentary-brazil-cifasacfis-mozambique-angola-mexico-malawi.pdf $>$. Acesso em: 15 set. 2015. 
As cláusulas materiais de proteção dos ACFIs seguem a estrutura básica dos APPRIs, contudo, pode-se afirmar que essas não são unívocas, haja vista que existem algumas diferenças entre elas em vários dispositivos. Em certas matérias, reconhece-se também uma distinção geográfica entre os ACFIs africanos e latino-americanos, como no caso do padrão de tratamento nacional e a sua extensão de proteção à fase de préestabelecimento nos instrumentos africanos.

Ademais, faz-se necessário destacar a questão das definições, que embora não sejam idênticas em todos os ACFIs, no acordo com Angola isso se mostra particular em decorrência da estipulação de que as definições serão fornecidas pelo ordenamento jurídico nacional das Partes. Como exposto, esta disposição acaba trazendo situações complexas à baila, pois não se especifica qual dos dois ordenamentos se aplicará, e sempre haverá o risco de que se sobrevenham novas legislações, como a mais recente Lei de Investimentos Privados de Angola, promulgada em agosto de 2015, após a assinatura do ACFI, bem como as leis internas que abordam a matéria, por serem específicas, podem não cobrir toda a complexidade que envolve o tema, o que faz raciocinar que, de fato, seria mais prático se as Partes tivessem delimitado no corpo do tratado as definições ao invés de deixar a competência interpretativa a cargo das leis nacionais. Entretanto, ressalta-se que mesmo que estas definições existam, elas devem ser claras e bem elaboradas, para que não haja dificuldades de interpretação normativa.

No que se refere ao tratamento conferido aos nacionais das Partes em território da outra Parte, nos ACFIs assim como nos outros APPRIs prevê-se o tratamento nacional e da nação mais favorecida, como salvaguardas contra a discriminação com relação aos benefícios concedidos ao investidor nacional e a investidores nacionais de Estados terceiros. O ACFI com a Colômbia vai além e prevê um rol positivo não exaustivo quanto a quais situações não poderá haver tratamento menos favorável. Não obstante, com a aplicação da nação mais favorecida aventa-se a possibilidade de extensão das obrigações previstas em outros tratados firmados pelo Estado receptor de modo a se blindar particularmente da importação da cláusula de solução de controvérsias de outros instrumentos. Tal como ocorreu no caso Maffezzini, os ACFIs com México e Colômbia proíbem a interpretação extensiva decorrente de disposições relativas à solução de controvérsias, com ganas de evitar a importação da cláusula de permite a arbitragem de investimentos, previsão que, conforme será analisada posteriormente no capítulo 5, não está contida nos ACFIs. 
Ainda quanto ao tratamento, apesar dos ACFIs não estipularem diretamente o tratamento justo e equitativo em uma cláusula geral padrão e este conceito ser bastante amplo, infere-se que este pode ser identificado nos ACFIs através de alguns elementos concretos que vedam determinadas condutas imputadas ao Estado e que compõem a intepretação deste princípio, como já decidido em jurisprudência passada do CIRDI. O primeiro deles é o devido processo legal, que é abarcado pelo tratamento justo e equitativo ao passo que o Estado deve garantir regularmente todas as etapas do processo aos investidores, e o segundo é a transparência, que deve estar presente tanto nos procedimentos judiciais e administrativos quanto deve ser garantido um quadro regulatório transparente com vistas a fornecer maior previsibilidade ao investidor.

Ademais, ressalta-se que a inquietação gerada no passado com a ausência de menção à compensação por títulos da dívida pública foi sanada, mesmo que esta não esteja prevista no tópico que aborda a compensação, haja vista estar contida quando se trata de transferências ao se habilitar a livre transferência também do montante de indenização ou valor de recursos obtidos com a venda no mercado de títulos recebidos como indenização.

Nesse diapasão, a previsão da responsabilidade social corporativa demonstra o intuito dos governos em promover um investimento responsável e que contribua de forma positiva para a comunidade local, o que se mostra concatenado com a nova geração dos APPRIs, que está preocupada com a máxima proteção do meio ambiente, do desenvolvimento sustentável, dos direitos humanos, dos padrões trabalhistas e das práticas da boa governança.

Por fim, tem-se que por mais que sejam previstos direitos e obrigações às partes nos acordos de investimento, não se pode olvidar que eventualmente poderão surgir controvérsias, que precisarão ser conduzidas da melhor maneira possível, com regras e procedimentos bem definidos. Ao longo do século XX, diversas iniciativas foram criadas adjudicatórias ou não - com o objetivo de prover um sistema eficiente que pudesse dirimir disputas sobre investimentos ou até mesmo, que pudesse evitar que qualquer entrave progredisse para uma controvérsia. Dessa forma, pretende-se no próximo capítulo abordar os principais métodos de prevenção e solução de controvérsias e a institucionalização e normatização desses procedimentos perante a ordem internacional. 


\section{SOLUÇÃO E PREVENÇÃO DE CONTROVÉRSIAS SOBRE INVESTIMENTOS}

No mundo globalizado, observa-se que os conflitos entre os mais diversos atores têm se multiplicado progressivamente, exigindo respostas rápidas e efetivas que englobem minimamente os interesses de todas as partes. Ao se referir aos meios para se lidar com as controvérsias, utiliza-se com frequência os termos "resolução" e "solução", palavras que indicam "o ato ou o fato de "solver", de responder a uma questão ou pôr fim a algo"325. Diante disso, faz-se necessária a análise prévia do conflito para que se possa identificar a sua vocação e, posteriormente, adeque-se o método ideal de solução ao tipo de conflito (e não vice-versa).

Nesse processo de escolha do meio adequado para solucionar a disputa deve ser considerado não apenas o método de solução de controvérsias que envolva o menor dispêndio de tempo e de recursos para a obtenção do resultado, mas também quais os benefícios qualitativos que poderão ser alcançados pela sua utilização. Assim, é preciso levar em conta a relação interpessoal envolvida, o direito material discutido e os interesses das partes em litígio ${ }^{326}$.

No plano do Direito dos Investimentos não é diferente, havendo uma variedade de opções para que se promova a resolução das controvérsias levantadas. Destarte, o presente capítulo evidenciará os meios jurídicos internacionais de solução de controvérsias, consubstanciados na arbitragem investidor-Estado; os métodos alternativos de solução de disputas e meios preventivos de solução de controvérsias, estes últimos com o intuito de se evitar que uma disputa efetivamente ocorra. Ademais, será ressaltada também a teoria da sombra do direito, já utilizada em diversos sub-ramos do Direito, para que se compreenda a influência do direito nas soluções negociadas e crie-se subsídios para que esta teoria possa ser aplicada ao Direito dos Investimentos.

\footnotetext{
${ }^{325}$ GABBAY, Daniela; FALECK, Diego; TARTUCE, Fernanda. Meios alternativos de solução de conflitos. Rio de Janeiro: FGV, 2013. p. 9.

${ }^{326}$ GALANTER, Marc. Compared to what? Assessing the quality of dispute processing. Denver University Law Review, n. 66, issue 3, p. 1989. p. xi-xiv.
} 


\subsection{MEIOS JUDICIAIS DE SOLUÇÃO DE CONTROVÉRSIAS SOBRE INVESTIMENTOS}

A função jurisdicional consiste na garantia do cumprimento das leis e regulamentos que não tenham sido voluntariamente observadas pelos indivíduos. Desse modo, segundo Alberto do Amaral Júnior, “a essência da jurisdição, seja ela doméstica ou internacional, reside na presença de terceiro imparcial e independente, cujas decisões se impõem às partes de forma obrigatória" ${ }^{327}$. Apesar de as cortes nacionais dos Estados receptores serem as jurisdições tradicionais competentes para tratarem dos litígios entre investidor e Estado nacional, os ordenamentos jurídicos nacionais dos países em desenvolvimento se mostravam frágeis, inseguros e passíveis de influência à época do desenvolvimento do Direito dos Investimentos. Desse modo, coube ao Direito Internacional gerar alguma estabilidade e segurança para os fluxos de investimento mundo afora provendo um sistema de solução de controvérsias a partir da arbitragem de investimentos.

Dentre os meios jurisdicionais institucionais para a solução de controvérsias sobre investimentos, o Centro Internacional para Resolução de Disputas sobre Investimentos é, sem dúvida, o mais difundido e reconhecido. Criado na década de 1960 pelo Grupo Banco Mundial, ganhou maior dinamicidade apenas nos anos 1990, com o fim da União Soviética, tendo se tornado o principal foro para a resolução de disputas sobre investimentos, alcançando a marca, em 2014, de 497 casos $^{328}$. Entretanto, esta instituição não é a única apta a solucionar litígios desta natureza haja vista que nem todos os Estados são partes na Convenção de Washington de 1965, além do que, outros meios inicialmente instituídos para arbitragens comerciais internacionais não excluem de sua jurisdição a arbitragem de investimentos. Dessa forma, pretende-se explanar, primeiramente, a sistemática e funcionamento do CIRDI e, em seguida, a participação dos demais regulamento arbitrais que têm regido arbitragens de investimento, como é o caso das

\footnotetext{
${ }^{327}$ AMARAL JÚNIOR, Alberto do. Curso de direito internacional público. 2ed. São Paulo: Atlas, 2011. p. 267.

${ }^{328}$ INTERNATIONAL CENTRE FOR SETTLEMENT OF INVESTMENT DISPUTES. ICSID CaseloadStatistics (Issued 2015-1). 2015, p.7. Disponível $<$ https://icsid.worldbank.org/apps/ICSIDWEB/resources/Documents/ICSID\%20Web\%20Stats\%2020151\%20(English)\%20(2)_Redacted.pdf>. Acesso em: 25 set 2015.
} 
Regras de Arbitragem da UNCITRAL de 1976, e as Regras de Arbitragem da Câmara de Comércio Internacional (CCI) e da Câmara de Comércio de Estocolmo (CCE) ${ }^{329}$.

\section{1.1 Centro Internacional para Resolução de Disputas sobre Investimentos (CIRDI)}

Após a Segunda Guerra Mundial, a ordem internacional deparou-se com uma sequência de reações do Terceiro Mundo contra o capital estrangeiro. Diante da instabilidade gerada através de discriminações e interferências na propriedade privada dos investidores foi criado o CIRDI, com o intuito de estabilizar as relações entre investidores e Estados, fornecendo um arcabouço jurídico e administrativo para as arbitragens ad hoc sobre a matéria investimentos. Assim sendo, nesta seção pretende-se analisar a origem do sistema CIRDI, sua estrutura institucional, sua jurisdição, bem como suas peculiaridades, como a disponibilidade de um sistema de conciliação e o Mecanismo Complementar. Por fim, será exposto também o procedimento arbitral do CIRDI, bem como alguns destaques da situação do Centro e suas perspectivas e o posicionamento brasileiro em relação a ele.

\subsubsection{Formação e Contexto Histórico}

O Centro Internacional para Resolução de Disputas sobre Investimentos foi criado no contexto específico da Guerra Fria e, principalmente, do movimento de descolonização afro-asiática. Nos anos 1960, com o fenômeno das descolonizações, novos países independentes ingressaram no sistema internacional, como nas Nações Unidas e no Banco Internacional para Reconstrução e Desenvolvimento (BIRD), dentre outras instituições ${ }^{330}$. Nesse contexto, seguiu-se também uma onda de nacionalizações e expropriações de investimentos estrangeiros no Terceiro Mundo, sob a ameaça de instalação de regimes socialistas nesses territórios recém-independentes. Somadas a essas instabilidades,

${ }^{329}$ Mesmo sendo distintos em diversos aspectos, como na produção de documentos, de provas, no estabelecimento de padrões éticos para os árbitros e conciliadores e em sua estrutura de custos, o que todos esses procedimentos arbitrais têm em comum é o condão de controlar a composição dos tribunais arbitrais e o direito aplicável aos procedimentos, além de o próprio tribunal poder decidir acerca de sua própria competência e escolher a regra procedimental na ausência da escolha pelas partes e existir a garantia do princípio da confidencialidade. Assim, essa variedade de regulamentos arbitrais permite oferecer, doravante, uma mais amplitude de escolha tanto aos investidores estrangeiros, quanto aos Estados. Ademais, apesar de existirem outros centros importantes de arbitragem ao redor do mundo, nesse trabalho, optou-se pela inclusão apenas da CCI e da CCE, em função de sua maior notoriedade. Cf. CARREAU, Dominique; JUILLARD, Patrick. Droit international économique. 5ed. Paris: Dalloz, 2013, p. 585; DOLZER, Rudolf. SCHREUER, Christoph. Principles of international investment law. Oxford: Oxford University Press, 2008. p. 226.

${ }^{330}$ PARRA, Antonio. The history of ICSID. Oxford: Oxford University Press, 2012. p. 11. 
“disposições fiscais e financeiras de caráter discriminatório formavam o contexto propício para a criação de um mecanismo que favorecesse o ambiente para investimentos internacionais" ${ }^{\prime 331}$. Segundo Aron Broches, um dos fundadores da Convenção que veio a criar o CIRDI, era inegável que o receio de riscos políticos operava como um elemento dissuasor do fluxo de capital estrangeiro privado para os países em desenvolvimento ${ }^{332}$.

Atento a todos estes fatos, o Banco Mundial iniciou análise sobre como poderia evitar que essas situações se enveredassem para controvérsias entre os Estados receptores de investimentos e investidores estrangeiros ${ }^{333}$. O caráter multilateral do Banco e sua posição como intermediário financeiro entre países exportadores e importadores de capital contribuíram para inspirar confiança em relação à sua imparcialidade tanto para investidores quanto para Estados receptores de investimentos ${ }^{334}$. Além disso, conforme pontua novamente o supracitado autor Aron Broches, o Banco refletia-se como a instituição que poderia auxiliar na resolução dessas controvérsias ao mesmo tempo em que promoveria seu objetivo global de estimular o clima de investimentos estrangeiros privados e fomentar o desenvolvimento econômico entre os países menos desenvolvidos ${ }^{335}$.

Salienta-se que, em período anterior, o próprio Banco Mundial já havia atuado em favor da resolução de conflitos sobre investimentos, por intermédio de bons ofícios oferecidos no caso da Companhia de Petróleo Anglo-Iraniana (1951 e 1952). Ademais, o próprio presidente do Banco Mundial, já havia servido como mediador em disputas sobre investimentos relativas ao Canal de Suez, em 1956, e para isso mediu esforços através do Conselho Geral do Banco ${ }^{336}$. Assim, um dos objetivos da Convenção que criaria o Centro era regularizar institucionalmente a função de solucionar controvérsias internacionais sobre investimentos envolvendo Estado e nacionais de Estados diversos.

Ademais, conforme ressalta o diplomata Celso de Tarso Pereira, "a permanência de conflitos pendentes entre países e investidores, por falta de um instrumento adequado de

${ }^{331}$ PEREIRA, Celso de Tarso. O Centro Internacional para a Resolução de Conflitos sobre Investimentos (CIRDI-ICSID). Revista de Informação Legislativa, Brasília, ano 35, n. 40, p.87-93, out./dez. 1998. p. 88.

332 BROCHES, Aron. The Convention on the Settlement of Investment Disputes between States and Nationals of Other States. Recueil des Cours, n. 2, p. 331-410, 1972, p. 343.

${ }^{333}$ LOWENFELD, Andreas F. International economic law. 2nd. Oxford: Oxford University Press, 2008, p.537.

${ }^{334}$ PARRA, Antonio. The history of ICSID. Oxford: Oxford University Press, 2012. p. 22.

335 BROCHES, Aron. op. cit., p. 331-410, 1972, p.337-343; SCHREUER, Christoph. Do We Need Investment Arbitration? In Kalicki, Jean E.; Joubin-Bret, Anna. Reshaping the Investor-State Dispute Settlement System: Journeys for the 21st Century. Leiden and Boston: Brill Nijhoff, 2015, p. 880; SCHREUER, Christoph et al. The ICSID Convention: a commentary. Oxford: Oxford University Press, 2009. p. 10-11.

${ }^{336}$ LOWENFELD, Andreas F. op.cit., p. 536-537. 
solução de controvérsias, opera como um grave entrave ao comércio internacional" ${ }^{337}$. Isso, pois, os Estados recusam-se a se submeter a tribunais internos de outros países, e os investidores privados, algumas vezes, possuem a percepção de se encontrarem em posição desvantajosa ao se submeterem à legislação e às cortes nacionais do Estado receptor. Já o instituto da proteção diplomática, por depender da aceitação do Estado de origem do investidor para prosseguir com a demanda, muitas vezes era visto como instrumento de "politização indevida de interesses comerciais" ${ }^{338}$.

Em 1962, os Diretores Executivos do Banco Mundial se reuniram em Comissão para Resolução de Litígios sobre Investimentos, com o objetivo de delinear um draft especificando o papel e a estrutura organizacional da nova instituição que seria criada.

Dessa forma, por meio da Convenção sobre Resolução de Conflitos relativos a Investimentos entre Estados e Nacionais de outros Estados ou, simplesmente, Convenção de Washington de 1965, assinada em 18 de março de 1965 e em vigor desde 14 de outubro de 1966, foi criado o Centro Internacional para Resolução de Disputas sobre Investimentos, integrante do Grupo Banco Mundial. Ao lado de outras quatro organizações $^{339}$, o CIRDI detém o status de organização internacional com personalidade jurídica internacional, instituída via tratado e possui caráter intergovernamental e multilateral. Tem por objetivo facilitar a resolução de conflitos relativos a investimentos estrangeiros através da heterocomposição entre Estados e partes privadas investidoras ${ }^{340} \mathrm{e}$, principalmente, propiciar um ambiente de confiança mútua entre investidores e Estados nacionais, de forma a facilitar o fluxo de capitais para países em desenvolvimento por meio de termos e condições razoáveis ${ }^{341}$.

Por fim, a Convenção de Washington institui que o CIRDI oferecerá mecanismos apropriados tanto de conciliação, quanto de arbitragem, sendo que a função do Centro

${ }^{337}$ PEREIRA, Celso de Tarso. O Centro Internacional para a Resolução de Conflitos sobre Investimentos (CIRDI-ICSID). Revista de Informação Legislativa. Brasília, ano 35, n. 40, p. 87-93, out./dez. 1998 p.88.

338 Dessa forma, a despolitização da sistemática da solução de controvérsias internacionais foi um dos impulsionadores para a criação de uma jurisdição internacional voltada a arbitragens mistas investidorEstado. Cf. PARRA, Antonio. The history of ICSID. Oxford: Oxford University Press, 2012, p.16 e p. 35. PEREIRA, Celso de Tarso. O Centro Internacional para a Resolução de Conflitos sobre Investimentos (CIRDI-ICSID). Revista de Informação Legislativa. Brasília, ano 35, n. 40, p. 87-93, out./dez. 1998. p. 88 .

${ }^{339}$ Ressalta-se que o Grupo Banco Mundial é composto por: (i) Banco Internacional para Reconstrução e Desenvolvimento (BIRD); (ii) Associação Internacional do Desenvolvimento (AID); (iii) Sociedade Financeira Internacional (SFI); (iv) Agência Multilateral de Garantia de Investimentos (MIGA) e pelo Centro Internacional para Arbitragem de Disputas sobre Investimentos (ICSID).

${ }^{340}$ LOWENFELD, Andreas F. International economic law. 2nd. Oxford: Oxford University Press, 2008. p. 536-537.

${ }^{341}$ RAMINA, Larissa. Direito Internacional dos Investimentos. Curitiba: Juruá, 2009. p. 69. 
consistirá apenas em administrar esses procedimentos, deslocando-os dos sistemas jurídicos nacionais, e não os realizando diretamente.

\subsubsection{Estrutura Institucional}

Com sede em Washington (EUA), nas dependências do Banco Mundial, o CIRDI, como pessoa jurídica de Direito Internacional, possui imunidades e privilégios próprios, pelo que tanto seus funcionários, quanto os conciliadores e árbitros que constam nas listas do Centro gozam de privilégios e imunidades em razão de seu ofício (rationae officii) ${ }^{342}$. Ademais, como organização internacional, o CIRDI possui arcabouço institucional definido e consubstanciado em dois principais organismos.

O primeiro é o Conselho Administrativo, órgão plenário, presidido pelo Presidente do Grupo Banco Mundial, formado por um representante de cada Estado Contratante, que detém direito a voto, sendo que as decisões são tomadas por maioria (exceto se a Convenção exigir quórum distinto). O Conselho possui papel primordial no desempenho das seguintes funções: (i) eleição do Secretário e do Subsecretário Geral; (ii) formulação do orçamento do CIRDI; (iii) adoção de quaisquer regulações administrativas e financeiras e (iv) adoção de regulamentos para arbitragem e conciliação. O segundo é a Secretaria, responsável por administrar os procedimentos tanto conciliatórios, quanto arbitrais executados sob a jurisdição do CIRDI, e composta pelo Secretário Geral e um ou mais Subsecretários, juntamente com sua equipe administrativa ${ }^{343}$. O Secretário Geral é o representante legal do Centro, assumindo sua direção e administração. Sua função consiste em realizar a primeira análise dos pedidos de conciliação e arbitragem submetidos aos auspícios do CIRDI, bem como de autenticar as sentenças arbitrais. Os custos do Secretariado são financiados pelo orçamento do Banco Mundial, porquanto os procedimentos individuais são custeados pelas próprias partes envolvidas.

O Centro também detém listas de conciliadores e de árbitros, válidas por seis anos e elaboradas através de indicações periódicas dos Estados Contratantes - que indicam quatro referências nominais para cada lista - e do Conselho Administrativo, pelo que seu presidente indica dez nomes para cada lista. Ademais, essas listas funcionam apenas como

\footnotetext{
${ }^{342}$ PEREIRA, Celso de Tarso. O Centro Internacional para a Resolução de Conflitos sobre Investimentos (CIRDI-ICSID). Revista de Informação Legislativa, Brasília, ano 35, n. 40, 87-93, out./dez. 1998. p. 88.

${ }^{343}$ LUÍS, Daniel Tavela. Proteção do Investimento Estrangeiro: o Sistema do Centro Internacional para Resolução de Disputas Relativas ao Investimento (CIRDI) e suas Alternativas. 2013. 189 f. Dissertação (Mestrado em Direito) - Faculdade de Direito da Universidade de São Paulo, São Paulo, 2013. p. 82.
} 
indicação institucional, sendo que as partes não se encontram restritas a elas, podendo indicar quaisquer julgadores, mesmo que não presentes na relação elaborada pelo CIRDI. Contudo, no que tange às indicações realizadas pelo Presidente ou Secretário Geral, as listas são de caráter vinculante, dentre os nomes indicados ${ }^{344}$.

Desse modo, dentre as atividades realizadas pelo Centro, confere-se destaque à administração de conciliações e arbitragens, por meio da adoção de regulamentos concernentes aos procedimentos de conciliação e arbitragem; da elaboração de cláusulas modelo a serem utilizadas nas relações contratuais entre Estados e investidores; da manutenção de uma lista de conciliadores e de árbitros; da verificação burocrática e do registro de requerimentos de procedimentos de conciliação e arbitragem; da assistência na constituição das comissões de conciliação e dos tribunais arbitrais; da disposição de serviços e locais adequados para a realização dos procedimentos conciliatórios e arbitrais e da comunicação oficial de documentos e informações fundamentais para as partes ${ }^{345}$.

\subsubsection{Consentimento para Submissão ao CIRDI}

Ressalta-se que, o propósito do Banco Mundial era estabelecer um mecanismo judicial de solução de controvérsias neutro, não apenas entre Estados nos polos da disputa, mas sim, de um lado, composto por partes privadas, e de outro, Estados receptores de investimento. Dessa forma, uma das inovações da Convenção foi instituir a capacidade aos entes privados de integrar uma relação jurídica juntamente com um ator estatal.

Assim, a Convenção de Washington permite que as disputas sejam iniciadas tanto pelos investidores privados, quanto pelos Estados nacionais. Não obstante, a principal condição e, segundo Patrick Juillard, a pedra angular para a competência do Centro é o consentimento, ou seja, o ato de vontade pelo qual as partes autorizam expressamente a instauração dos mecanismos arbitrais de solução de controvérsias para um conjunto determinado ou determinável de matérias ${ }^{346}$. Ao ratificar a Convenção de Washington, os Estados reconhecem a sua jurisdição, entretanto, isso não obriga as partes a se submeterem

\footnotetext{
${ }^{344}$ COSTA, José Augusto Fontoura. Direito Internacional do Investimento Estrangeiro. Curitiba: Juruá, 2010. p. 205.

${ }^{345}$ PARRA, Antonio. The history of ICSID. Oxford: Oxford University Press, 2012. p. 141. LUÍS, Daniel Tavela. Proteção do Investimento Estrangeiro: O Sistema do Centro Internacional para Resolução de Disputas Relativas ao Investimento (CIRDI) e suas Alternativas. 2013. 189 f. Dissertação (Mestrado em Direito). Faculdade de Direito da Universidade de São Paulo, São Paulo, 2013. p. 83.

346 JUILLARD, Patrick. L'évolution des sources du droit des investissements. Recueil des cours, Leiden p. 9-216, 1994. p. 99. COSTA, José Augusto Fontoura. Op.cit.. p. 211.
} 
à arbitragem do CIRDI, pois faz-se necessário um duplo consentimento, ou seja, que as partes também consintam com a submissão ao Centro para resolver determinada controvérsia. Esse mesmo procedimento quanto à necessidade de consentimento expresso $\mathrm{e}$ por escrito também é aplicado ao Mecanismo Complementar.

Nesse sentido, infere-se que o acesso à solução de controvérsias do CIRDI não é automático, dependendo da aceitação por escrito de ambas as partes, o Estado e o investidor, conforme estabelecido no art. $25(1)$ da Convenção ${ }^{347}$, sendo que o consentimento conferido atua como limitador, não podendo os Estados ir além do que foi autorizado, seja mediante contrato, compromisso, lei $^{348}$, tratado ou qualquer outro meio. $\mathrm{O}$ consentimento expresso dos Estados pode se dar nas seguintes hipóteses não taxativas: (i) por meio de cláusula compromissória incorporada em um contrato entre as partes, estabelecendo, antecipadamente, que a resolução de eventuais litígios estará sob a jurisdição do $\mathrm{CIRDI}^{349}$; (ii) por compromisso arbitral (compromis), instituído para um litígio já existente ${ }^{350}$ (iii) por previsão em legislação nacional do Estado hospedeiro - na maioria das vezes, sua legislação interna sobre investimento ${ }^{351}$ - e (iv) através de um

${ }^{347}$ No original e, inglês, o art. 25 (1) da Convenção de Washington estipula: "Article 25 (1) The jurisdiction of the Centre shall extend to any legal dispute arising directly out of an investment, between a Contracting State (or any constituent subdivision or agency of a Contracting State designated to the Centre by that State) and a national of another Contracting State, which the parties to the dispute consent in writing to submit to the Centre. When the parties have given their consent, no party may withdraw its consent unilaterally".

${ }^{348}$ Quando a previsão estiver contida em lei interna, deve-se ter cuidado para manter a coerência com o ordenamento jurídico nacional, o que inclui os princípios constitucionais vigentes e as regras sobre vigência legislativa. Já se a autorização for dada mediante instrumento internacional, devem ser respeitadas as fontes internacionais, em especial quanto à validade e os efeitos dos tratados internacionais, "sendo relevante a remissão ao Direito interno apenas quando resultante da aplicação do Direito Internacional". COSTA, José Augusto Fontoura. Direito Internacional do Investimento Estrangeiro. Curitiba: Juruá, 2010, p. 215.

${ }^{349}$ Estas cláusulas são comuns em contratos entre Estados e investidores estrangeiros ou por intermédio de cláusulas modelo, já citadas anteriormente, preparadas e publicadas pelo CIRDI com o intuito de facilitar a elaboração desses contratos. Conforme pontua Bruno Oppetit, apesar de não existir nada mais variável e indeterminado quanto à vontade das partes, fez-se necessária a delineação da teoria da autonomia da cláusula compromissória para desarticular manobras dilatórias das partes, que se encontravam inicialmente de acordo a submeter-se à justiça arbitral. Assim, chancelada a vontade das partes com relação ao juízo, arbitram por meio da cláusula compromissória. Mesmo com a nulidade do contrato, a cláusula permanece válida e o juízo arbitral não poderá ser afastado, nem a questão deslocada à justiça estatal. Cf. OPPETIT, Bruno. Teoría del arbitraje. Bogotá: Legis, 2006. p. 105-106.

${ }^{350}$ OPPETIT, Bruno. Ibid.. p. 220.

${ }^{351}$ A opção realizada em favor de uma cláusula fork in the road será decisiva para o afastamento da arbitragem de investimentos, visto que esta permite que o investidor opte, através de uma escolha irreversível, pela solução de conflitos através de uma corte local ou a tribunais internacionais e, normalmente, após escolhida uma das vias, fica impossibilitado o recurso à outra. Cf. CARREAU, Dominique; JUILLARD, Patrick. Droit international économique. 5ed. Paris: Dalloz, 2013, p.585; MUCHLINSKI, Peter T. Multinational enterprises \& the law. 2ed. Oxford: Oxford University Press, 2007, p.722; REED, Lucy; PAULSSON, Jan; BLACKABY, Nigel. Guide to ICSID arbitration. 2ed. Alphen and den Rijn: Kluwer Law International, 2011, p.100. Ademais, quando o Estado consente através de lei nacional ou em tratado internacional ocorre a abertura de uma oferta, que pode ser aceita 
acordo de promoção e proteção recíproca de investimentos, por meio de cláusulas de resolução de conflitos que preveem o compromisso de utilização da jurisdição do CIRDI $^{352}$, como se fosse uma oferta pública de arbitragem durante o período de vigência do tratado. Os investidores, por sua vez, também poderão dar seu consentimento mediante cláusula compromissória, compromisso arbitral e simples início do procedimento ${ }^{353}$.

Uma vez consentindo à jurisdição, este consentimento não pode ser revogado unilateralmente, mesmo que haja tentativa de pôr termo ao contrato que possua cláusula de resoluções de controvérsias CIRDI. Além disso, nem a revogação da legislação nacional que preveja o consentimento poderá afetar a jurisdição do CIRDI, desde que a oferta tenha sido aceita enquanto a legislação ainda estivesse em vigor.

\subsubsection{Jurisdição}

Os limites de operação do Centro são instituídos pelo art. 25 da Convenção de Washington, que dispõe sobre a jurisdição do Centro. Todavia, mesmo a instituição não possuindo poderes jurisdicionais, porquanto o CIRDI apenas administra os procedimentos conciliatórios e arbitrais, essa terminologia é utilizada para significar os limites dentro dos

pelo investidor a qualquer momento, mesmo mediante a própria remissão do caso à arbitragem. Um dos leading cases que demonstram a aceitação do Estado à jurisdição do CIRDI via própria legislação interna é o caso Southern Pacific Properties (Middle East) Limited v. Arab Republic of Egypt (SPPv. Egypt), ICSID Case n. ABR/84/3, 24 August 1984, em que o Egito refutou a submissão à solução de controvérsias do CIRDI por não haver nenhuma cláusula arbitral ou compromisso com o investidor que estabelecesse essa relação. Porém, o art. $8^{\circ}$ da Lei $\mathrm{n}^{\circ} 43$ de 1974, que regulava a matéria relativa aos investimentos árabes e fundos estrangeiros e zonas francas previa que as disputas de investimento deveriam ser solucionadas da maneira a ser acordada com o investidor, ou dentro da estrutura dos acordos em vigor entre a República Árabe do Egito e o país natural do investidor, ou dentro da estrutura da Convenção para Solução de Disputas de Investimentos entre o Estado e os nacionais de outros países, à qual o Egito aderiu. Portanto, a lei nacional consentia com a arbitragem mista e o tribunal arbitral, portanto, tinha jurisdição sobre a disputa. Cf. ISMAIL, Mohamed A.M. International Investment Arbitration: Lessons from development in the Mena Region. Burlington: Ashgate USA, 2013. p. 154; NEWCOMBE, Andrew; PARADELL, Lluís. Law and practice of investment treaties: standards of treatment. The Hague: Kluwer Law International, 2009. p. 46.

${ }^{352}$ Segundo Newcombe e Paradell, até 1968, os TBIs forneciam apenas a solução de controvérsias por meio de arbitragem Estado-Estado ou pela submissão do litígio à Corte Internacional de Justiça (CIJ). Os primeiros acordos a adotarem uma cláusula de submissão à arbitragem mista sob os auspícios do CIRDI foram os entre Holanda e Indonésia, de 1968, e os da Itália com o Chade e a Costa do Marfim, em 1969. Nos anos 1990, essa tendência evolutiva converteu-se em regra e a esmagadora maioria dos acordos já consentia a arbitragem mista. Cf. NEWCOMBE, Andrew; PARADELL, Lluís. Ibid.. p.44. COSTA, José Augusto Fontoura. Direito Internacional do Investimento Estrangeiro. Curitiba: Juruá, 2010. p. 214. INTERNATIONAL CENTRE FOR SETTLEMENT OF INVESTMENT DISPUTES. ICSID Convention, Regulation and Rules. Report of the Executive Directors on the Convention on the Settlement of Investment Disputes between States and Nationals of Other States, 2006, p. 43. Disponível em: $<$ https://icsid.worldbank.org/ICSID/StaticFiles/basicdoc/CRR_English-final.pdf>. Acesso em: 27 set. 2015.

353 CARREAU, Dominique; JUILLARD, Patrick. Droit international économique. 5ed. Paris: Dalloz, 2013. p 582-583. 
quais as disposições da Convenção serão aplicadas e os limites em que os mecanismos de conciliação e a arbitragem estarão disponíveis. Já a competência do CIRDI, prevista no art. 41(1), refere-se propriamente à "capacidade do tribunal de exercer a jurisdição geral do CIRDI em um caso particular, e proferir uma sentença arbitral final”354.

Assim, o artigo 25 da Convenção de Washington estabelece três critérios necessários e cumulativos para a jurisdição do CIRDI. O primeiro deles, já exposto anteriormente, é o consentimento voluntário (rationae voluntatis), que deve ser expresso e por escrito. $\mathrm{O}$ segundo, trata-se da extensão jurisdicional em razão da matéria (rationae materiae), em que devem estar presentes duas condições essenciais: (i) a controvérsia deve ser jurídica e (ii) esta deve ter surgido diretamente de um investimento.

Ora, a limitação às controvérsias jurídicas torna-se relevante, ao passo que afasta da análise do Centro conflitos de interesses entre as partes, conflitos de conteúdo político ou econômico-comercial, bem como questões fáticas. Desse modo, a controvérsia deve ser focada na violação ou reparação de direitos e obrigações.

No que se refere à definição de investimento, esta inexiste no texto da Convenção. Isso se dá em razão da dificuldade encontrada em se propor uma definição multilateral, em função da multiplicidade de concepções acerca da matéria. Segundo o Relatório dos Diretores Executivos "nenhuma tentativa foi feita tendo em conta o requisito essencial do consentimento das partes"355, além disso, o art. 25(4) dispõe que, de forma discricionária, cada Estado contratante poderá comunicar ao Centro as categorias de controvérsia que pretende submeter à jurisdição do CIRDI, ou o que de acordo com seu direito interno não poderia ser alvo de submissão à sua jurisdição. Contudo, apesar da previsão presente no Relatório, os trabalhos preparatórios da Convenção previam grandes esforços para definir o termo investimentos, sem jamais ter alcançado consenso quanto ao ponto; e, seguindo a proposta da delegação britânica, não se adotou definição no âmbito da Convenção, o que facilitou sua aprovação ${ }^{356}$. Ademais, conforme aduz Aron Broches, a opção pela não inclusão da definição de investimentos se coaduna com o consentimento para a submissão ao Centro, pois, se as partes estão de acordo em submeter uma disputa ao Centro, presume-se que o objeto da controvérsia se refere materialmente a um

\footnotetext{
${ }^{354}$ RAMINA, Larissa. Direito Internacional dos Investimentos. Curitiba: Juruá, 2009. p. 149.

${ }^{355}$ No original em inglês: "no attempt was made given the essential requirement of consent by the parties".

${ }^{356}$ SORNARAJAH, M. The International Law of Foreign Investment. 3rd. New York: Cambridge University Press, 2010. p. 308-313; COSTA, José Augusto Fontoura. Direito Internacional do Investimento Estrangeiro. Curitiba: Juruá, 2010. p. 207.
} 
investimento $^{357}$. Assim, cabe às próprias partes a delimitação da definição do sentido de investimento, por intermédio dos APPRIs ${ }^{358}$.

Quanto à jurisdição em razão da pessoa (rationae personae), o art. 25 especifica que serão legítimos para acionar o CIRDI os Estados Contratantes e os nacionais de um Estado Contratante diverso daquele que integra o outro polo da ação. Desse modo, por nacional de outro Estado, segundo o art. 25 (2), entende-se qualquer pessoa física ou jurídica, desde que investidora e nacional de outro Estado Contratante.

Quanto às pessoas físicas, o critério basilar é o da nacionalidade, que deve existir no momento em que foi dado o consentimento e quando se efetiva a submissão à arbitragem ou conciliação, não importando o local do domicílio ou residência da pessoa ${ }^{359}$.

Sobre as pessoas jurídicas, estas incluem não somente as corporações estrangeiras ou entidades jurídicas privadas, mas também empresas "com capital estatal, ou mesmo controlada integralmente por um Estado estrangeiro, desde que não exerça função pública ou represente o governo" ${ }^{360}$. Já no que se refere à determinação da nacionalidade da empresa, faz-se necessário que ela detenha nacionalidade diferente da nacionalidade do Estado hospedeiro. Ora, a nacionalidade da pessoa jurídica será determinada pelo critério do local de seu registro ou pelo lugar de sua sede social, ou então, conforme disposto no art. 25 (2) (b), por meio de acordo entre o Estado hospedeiro e o investidor, que apesar de possuir nacionalidade do Estado litigante, encontra-se sob controle estrangeiro. Caso a empresa apresente mais de uma nacionalidade é necessário que pelo menos uma delas seja de um Estado contratante, desde que distinta do Estado presente no outro polo da controvérsia ${ }^{361}$.

${ }^{357}$ PUCCI, Adriana Noemi. Solução de Controvérsias Relativas a Investimentos Estrangeiros. 2003. 330 f. Tese (Doutorado em Direito) - Faculdade de Direito da Universidade de São Paulo, São Paulo, 2003. p. 247.

${ }^{358} \mathrm{O}$ fato é que a dificuldade no alcance de uma definição é reforçada pelo fato de que na época em que a Convenção foi redigida, o significado de investimento não ia muito além do significado convencional de contrato de longo prazo para a exploração de recursos naturais ou de um project contract. Hoje em dia, admite-se na definição, conforme previsão no acordo, inclusive os investimentos de portfólio, fluxos de capital que não são orientados para o controle operacional da empresa. Cf. SORNARAJAH, M. The international law on foreign investment. 3rd. Cambridge: Cambridge University Press, 2010. p. 311.

${ }^{359}$ DOLZER, Rudolf; SCHREUER, Christoph. Principles of international investment law. Oxford: Oxford University Press, 2008. p. 237.

${ }^{360}$ COSTA, José Augusto Fontoura. Direito Internacional do Investimento Estrangeiro. Curitiba: Juruá, 2010. p. 207.

${ }^{361}$ Segundo Celso de Tarso Pereira, esta provisão justifica-se: "pela condição imposta muitas vezes ao investidor estrangeiro, pelo Estado receptor, de conduzir seus negócios por intermédio de uma empresa formada sob suas leis. Se não se fizesse exceção ao caso de empresas sob controle estrangeiro, mas registradas no Estado receptor, uma importante esfera de investimentos não seria abrangida pela Convenção". PEREIRA, Celso de Tarso. O Centro Internacional para a Resolução de Conflitos sobre Investimentos (CIRDI-ICSID). Revista de Informação Legislativa, Brasília, ano 35, n. 40, p.87-93, out./dez. 1998. p. 90. 
Ainda sobre a jurisdição do Centro, o art. 26 da Convenção de Washington estabelece firmemente que, uma vez dado o consentimento das partes para a arbitragem sob a égide do Centro, exceto provisão em contrário, exclui-se qualquer outro remédio jurisdicional. O Estado demandado tampouco poderá contestar a jurisdição do tribunal arbitral com fulcro na ausência de esgotamento prévio dos recursos internos para acessar o tribunal, porém, poderá requerer esse esgotamento como condição para o consenso à arbitragem, apesar de ser uma reserva rara nos acordos de investimento e encontrada com mais frequência em TBIs mais antigos ${ }^{362}$.

Finalmente, de acordo com o art. 27 da Convenção, ao aderir a esta, suspende-se o direito do exercício da proteção diplomática por parte do Estado de origem do investidor para o resguardo do direito de seus nacionais, salvo se o Estado parte da controvérsia recusar-se a cumprir a sentença arbitral.

\subsubsection{Mecanismo Complementar}

De acordo com a Convenção de Washington, para que a demanda possa ser processada pelo Centro, tanto o país de procedência do investidor, quanto o país receptor destes investimentos devem ser partes da Convenção. Contudo, em 27 de setembro de 1978, na $12^{\mathrm{a}}$ reunião do Conselho Administrativo do Centro, decidiu-se por meio da implementação do Mecanismo Complementar, que o Secretário Geral do Centro ficaria autorizado a administrar certos procedimentos entre Estados e nacionais de outros Estados não-contratantes do Centro, pela ausência dos requisitos rationae personae e rationae materiae. Isso se daria em razão, principalmente, de uma das partes não se tratar de Estado Contratante ou de nacional de um Estado Contratante e visar o acesso ao Centro ou, em categoria adicional, se a controvérsia não surgir diretamente de um investimento ${ }^{363}$.

${ }^{362}$ DOLZER, Rudolf; SCHREUER, Christoph. Principles of international investment law. Oxford: Oxford University Press, 2008. p. 249.

${ }^{363}$ PARRA, Antonio. The history of ICSID. Oxford: Oxford University Press, 2012. p. 147-150. DOLZER, Rudolf; SCHREUER, Christoph. Principles of international investment law. Oxford: Oxford University Press, 2008. p. 224-225. COSTA, José Augusto Fontoura. Modelos de solução de controvérsia investidor-Estado: os mecanismos nacionais e internacionais. In: AMARAL JÚNIOR, Alberto do; SANCHEZ, Michelle Ratton. (Coord.) Regulamentação internacional dos investimentos: algumas lições para o Brasil. São Paulo: Aduaneiras, p. 325-354, 2007, p. 338. Além disso, procurava-se uma forma de publicidade, mostrando aos Estados não signatários e aos particulares os benefícios do sistema de solução de controvérsias do ICSID. Cf. COSTA, José Augusto Fontoura; CARREGARO, Ana Carolina Costa; ANDRADE, Thiago Pedroso de. Mecanismo Complementar do ICSID: uma alternativa para investidores brasileiros? Revista Direito GV, São Paulo v. 3, n. 2, p. 59-76, nov. 2007, p. 64. 
Desse modo, o Mecanismo Complementar possibilitou a ampliação da utilização dos mecanismos de solução de controvérsias do CIRDI, desde que o Estado de uma das partes seja contratante e que ambas as partes optem por se submeter ao Centro. Entretanto, se nenhum dos Estados envolvidos é parte na Convenção, não se poderá acionar o Mecanismo Complementar. Iniciado o procedimento do Mecanismo, as partes não poderão utilizar outro meio para solucionar as controvérsias. No entanto, caso haja tradicional disputa envolvendo Estados Contratantes ou nacionais de Estados Contratantes, será utilizado o procedimento da Convenção de Washington e não o do Mecanismo ${ }^{364}$.

Além disso, o Mecanismo Complementar pode funcionar de forma mais abrangente do que o CIRDI tanto em razão da matéria, quanto em razão da pessoa. Isso, pois, algumas matérias que não eram abarcadas pelo CIRDI passam a ser aceitas por meio do Mecanismo Complementar, como disputas que não tenham emergido diretamente de um investimento, mas que ao mesmo tempo não se caracterizam como uma transação comercial ordinária.

Outrossim, quanto ao arcabouço regulatório, o Mecanismo possui regulamentos próprios que regem seus procedimentos, tais quais o Regulamento de Conciliação (RCMC), o Regulamento de Arbitragem (RAMC) e o Regulamento de Produção de Prova Antecipada (RPPA). Os procedimentos englobados pelo Mecanismo incluem: (i) Procedimento de Conciliação e Arbitragem para a solução de controvérsias relativas a investimentos, para partes que não se constituem como Estado Contratante ou nacional de Estado Contratante; (ii) Procedimentos de Conciliação e Arbitragem para a solução de controvérsias relativas a investimentos, para quando a controvérsia não surja diretamente da matéria investimentos; (iii) Procedimentos de constatação de fatos (fact-finding proceedings).

$\mathrm{O}$ art. $2^{\circ}$ do Regulamento do Mecanismo Complementar dispõe sobre o procedimento de constatação de fatos, o qual corresponde a uma espécie de inquérito, que desencadeará na produção de provas. Esse dispositivo, que não se encontra presente no âmbito da Convenção de Washington, possui papel ímpar para uma posterior conciliação ou arbitragem ou para a facilitação de uma futura solução negociada. Seu funcionamento se dá anteriormente à disputa, e tem como objetivo concatenar a vontade das partes com o intuito de uniformizar as questões de fato (e não de direito) de forma imparcial, o que

${ }^{364}$ DOLZER, Rudolf; SCHREUER, Christoph. Principles of international investment law. Oxford: Oxford University Press, 2008. p.224-225; COSTA, José Augusto F.; CARREGARO, Ana Carolina C.; ANDRADE, Thiago P. Mecanismo complementar do ICSID: uma alternativa para investidores brasileiros? Revista Direito GV, São Paulo. v.3, n.2, p. 59-76, jul-dez. 2007. p. 59-76. 
facilitará para a instrução probatória para uma futura arbitragem ${ }^{365}$. Isso colabora para prevenir entendimentos diversos sobre os fatos, que podem evoluir para uma futura controvérsia jurídica.

Em razão de sua base contratual, o Mecanismo Complementar se distingue da Convenção de Washington no que tange à execução de laudos arbitrais, visto que sua execução está sujeita ao regime empregado aos laudos estrangeiros conforme a lei do local de execução. Desse modo, de acordo com o art. 19 das Regras do Mecanismo Complementar, o Mecanismo exige que a sede da arbitragem, onde será proferido obrigatoriamente o laudo, deve ser determinada no território de um Estado que seja parte da Convenção de Nova Iorque sobre o Reconhecimento e a Execução de Laudos Arbitrais Estrangeiros (Convenção de Nova Iorque de 1958) ${ }^{366}$.

Ademais, o Mecanismo Complementar foi criado inicialmente para que funcionasse por cinco anos, contudo, devido ao seu sucesso, em 1984, o Conselho Administrativo do CIRDI decidiu mantê-lo por tempo indeterminado. O fato é que, o Mecanismo Complementar trata-se de instituto que auxilia na expansão do acesso à justiça internacional, visto que propicia oportunidade de acesso à jurisdição do Centro mesmo para Estados e investidores oriundos de Estados não signatários da Convenção de Washington, o que faz com que o CIRDI seja visto como alternativa também por esses atores. Assim sendo, devido aos benefícios desse mecanismo, Estados que não ratificaram a Convenção de Washington, como por exemplo, Brasil, Índia e África do Sul, podem vislumbrar o Mecanismo Complementar como real possibilidade para dirimir controvérsias sobre investimentos ${ }^{367}$.

\subsubsection{Mecanismo de Conciliação}

O CIRDI possui Regras Procedimentais para Conciliação (Rules of Procedure for Conciliation Proceedings) ou Regras de Conciliação (Conciliation Rules), adotadas em

${ }^{365}$ COSTA, José Augusto Fontoura. Direito Internacional do Investimento Estrangeiro. Curitiba: Juruá, 2010, p.207; COSTA, José Augusto F.; CARREGARO, Ana Carolina C.; ANDRADE, Thiago P. Mecanismo complementar do icsid: uma alternativa para investidores brasileiros? Revista Direito GV, São Paulo, v. 3, n. 2, p.59-76, jul./dez. 2007. p. 67.

${ }^{366}$ XAVIER JÚNIOR, Ely Caetano. Direito internacional dos investimentos e o Brasil: uma perspectiva a partir do padrão de tratamento justo e equitativo. 2014. 279 f. Dissertação (Mestrado em Direito) Faculdade de Direito da Universidade Estadual do Rio de Janeiro, Rio de Janeiro, 2014. p.71-72.

${ }^{367}$ INTERNATIONAL CENTRE FOR SETTLEMENT OF INVESTMENT DISPUTES. Database of ICSID Member States. Disponível em: $<$ https://icsid.worldbank.org/ICSID/FrontServlet?requestType=ICSIDDocRH\&actionVal=ShowDocume nt\&language=English $>$. Acesso em: 17 out. 2014 . 
1967 ao mesmo tempo que as Regras de Arbitragem do Centro. Em 1978, foram adotadas as Regras de Conciliação do Mecanismo Complementar, para casos em que uma das partes não é membro do CIRDI ou a disputa não é inteiramente relativa a investimentos ${ }^{368}$.

Segundo Reinisch e Malintoppi, o mecanismo de conciliação do CIRDI trata-se de método flexível e informal, envolvendo uma terceira parte neutra para dar assistência às partes no alcance de um acordo ${ }^{369}$. Os procedimentos de conciliação no CIRDI iniciam-se quando um Estado membro submete um pedido para conciliação à Secretaria Geral. Esta, por sua vez, irá devidamente enviar cópia do pedido ao outro Estado parte envolvido e, depois, registrar os procedimentos conciliatórios. Uma comissão de conciliação, que pode consistir em um único conciliador, ou em um número desigual de conciliadores (como acordado pelas partes), será estabelecido. Se as partes falharem em atingir um acordo, uma comissão de três conciliadores será constituída. Um conciliador será escolhido por cada parte e o terceiro (que será o presidente da comissão) será escolhido por mútuo acordo das partes. Se a comissão não for constituída com a notificação do Secretariado Geral, em 90 dias do pedido de conciliação, o Presidente do Conselho de Administração deverá apontar a Comissão ${ }^{370}$.

Esta Comissão é responsável por clarificar as questões em disputa, o que acarretará em acordo mutualmente aceito pelas partes. Para atingir esse objetivo, a comissão pode fazer recomendações para definir os termos da disputa, que serão consideradas pelas partes ${ }^{371}$. Se o acordo for alcançado, a comissão preparará um relatório dispondo a questão objeto da controvérsia e a natureza do acordo alcançado. Se um acordo mutualmente aceito não for atingido, a Comissão irá encerrar os procedimentos e preparar um relatório também prevendo as questões controversas e registrar a falha no acordo. É interessante notar que o CIRDI possui poucos processos de conciliação, segundo o ICSID Caseload-Statistics (Issued 2015-1), apenas 2\% dos procedimentos do CIRDI são conciliatórios $^{372}$.

${ }^{368}$ UNITED NATIONS CONFERENCE ON TRADE AND DEVELOPMENT. Series on International Investment Policies for Development. Investor-State Disputes: Prevention and Alternatives to Arbitration. New York and Geneva: United Nations, 2010. p. 54.

${ }^{369}$ REINISCH, August; MALINTOPPI, Loretta. Methods of dispute resolution In MUCHLINSKI, Peter; ORTINO, Federico; SCHREUER, Christoph (Coord).The Oxford Handbook of International Investment Law. Oxford: Oxford University Press, p.691-720, 2008. p. 702-703.

${ }^{370}$ REED, Lucy; PAULSSON, Jan; BLACKABY, Nigel. Guide to ICSID arbitration. 2nd. Alphen and den Rijn: Kluwer Law International, 2011. p. 20.

${ }^{371}$ PARRA, Antonio. The history of ICSID. Oxford: Oxford University Press, 2012. p. 35.

372 INTERNATIONAL CENTRE FOR SETTLEMENT OF INVESTMENT DISPUTES. ICSID Caseload$\begin{array}{llllll}\text { Statistics } & \text { (Issued 2015-1). } & \text { 2015. } & \text { Disponível }\end{array}$ 


\subsubsection{Procedimento Arbitral}

O procedimento arbitral no CIRDI inicia-se com a requisição por escrito de arbitragem pela parte demandante. Esta, que deverá conter, além da identificação das partes, também o consentimento escrito, será encaminhada ao Secretário Geral, que a aprovará e encaminhará cópia à outra parte. A requisição somente será denegada se a disputa estiver fora do alcance da Convenção. Salienta-se que no Mecanismo Complementar o procedimento é parecido, contudo, neste, o acordo das partes em recorrer ao Mecanismo deverá conter aprovação prévia do Secretário Geral, conforme previsto no art. $4^{\circ}$ do Regulamento do Mecanismo Complementar e $3^{\circ}$ (1) "c" do Regulamento de Arbitragem do Mecanismo Complementar.

Constituído o tribunal arbitral, a regra é que este será composto por árbitro singular ou número ímpar de árbitros. Não havendo indicação quanto ao número de árbitros, este será de três, sendo que cada parte indicará um deles, e o terceiro, futuro presidente do tribunal, será indicado em comum acordo entre as partes. Caso os árbitros não tenham sido indicados e o tribunal não tenha sido constituído em um prazo de 90 dias, o art. 38 da Convenção de Washington estabelece que o Secretário Geral poderá indicá-lo (s), contudo, limitando-se a não ser de nacionalidade de qualquer das partes e devendo estar presentes na lista institucional de árbitros. Sob a égide do Mecanismo Complementar, ressalta-se, tanto a lista de conciliadores, quanto de árbitros, não é relevante, contudo, exige-se que este não tenha atuado em procedimento anterior de produção de provas ou conciliação, exceto se as partes dispuserem em contrário. Além disso, os árbitros devem possuir distinta reputação e caráter moral e renomada competência nas áreas do Direito, comércio, indústria, finanças e condições de efetuar julgamento independente ${ }^{373}$.

A atuação do tribunal arbitral é direcionada pelo princípio da KompetenzKompetenz, em que o próprio árbitro é o competente para julgar se tem competência para atuar em determinada controvérsia, sem que se precise recorrer a autoridade judicial diversa para o esclarecimento dessa informação. Dessa forma, constata-se que a arbitragem de investimentos do CIRDI possui caráter autônomo, sem que os tribunais nacionais possam interferir na questão da própria jurisdição do Centro. Assim, se corte nacional de

https://icsid.worldbank.org/apps/ICSIDWEB/resources/Documents/ICSID\%20Web\%20Stats\%2020151\%20(English)\%20(2)_Redacted.pdf>. Acesso em: 25 set 2015.

${ }^{373}$ COSTA, José Augusto Fontoura. Direito Internacional do Investimento Estrangeiro. Curitiba: Juruá, 2010. p. 219. 
um Estado Contratante que tenha ação apresentada contra ele prevê arbitragem CIRDI, o juízo nacional deve interromper o curso da ação até que uma definição da questão seja proferida pelo Centro ${ }^{374}$.

No que se refere ao procedimento aplicável, em função de seu caráter institucional, o próprio CIRDI o define através das Regras Processuais Aplicáveis aos Procedimentos de Conciliação e as Regras Processuais Aplicáveis ao Procedimento de Arbitragem e, no âmbito do Mecanismo Complementar, pelo Regulamento de Arbitragem do Mecanismo Complementar, apesar de haver previsão no art. 44 da Convenção de Washington que possibilita a escolha de outro regime procedimental.

$\mathrm{O}$ art. 42 da Convenção dispõe sobre a lei aplicável, estabelecendo ampla liberdade para as partes em relação à indicação da lei material, tanto a lei nacional, quanto internacional ou a mescla das duas. Um ponto sensível se refere às leis nacionais do Estado receptor que, por pressões políticas ou econômicas, pode alterá-las, o que remete a riscos e insegurança jurídica a alguns ativos. Por isso, muitos contratos apresentam mecanismo denominado cláusula de estabilização, que prevê o congelamento das disposições legais estabelecidas à época da celebração do contrato. Desse modo, tem-se que a indicação da lei aplicável não deixa de ser um risco para o investidor ${ }^{375}$. Caso a lei aplicável não seja definida, o tribunal arbitral aplicará as normas internacionais cabíveis e o direito do Estado parte na controvérsia, o que inclui suas regras sobre conflito de leis.

Ademais, as partes podem ainda autorizar o tribunal arbitral a decidir por equidade (ex aequo et bono), ou seja, de acordo com padrões de justiça, sem levar em conta o direito positivo, e, no art.42 (2), há previsão sobre a proibição do non liquet, ou seja, todas as questões suscitadas devem ser julgadas pelo árbitro.

Há de se ressaltar que alguns TBIs oferecem mais de uma forma possível de arbitragem investidor-Estado, ou seja, além do sistema principal, há também um alternativo, seja ele institucional, seja ele ad hoc. Exemplo concreto é o TBI entre Indonésia e Moçambique, de 1999, que prevê três procedimentos possíveis para a resolução de conflitos:

Article VII

Settlement of Disputes between an Investor and a Contracting Party [...]

\footnotetext{
${ }^{374}$ PEREIRA, Celso de Tarso. O Centro Internacional para a Resolução de Conflitos sobre Investimentos (CIRDI-ICSID). Revista de Informação Legislativa, Brasília, ano 35, n. 40, p.87-93, out./dez. 1998. p. 90 .

${ }^{375}$ COSTA, José Augusto Fontoura. Direito Internacional do Investimento Estrangeiro. Curitiba: Juruá, 2010. p. 220.
} 
3. Where the dispute is to be referred to international arbitration, the investor and the Contracting Party involved in the dispute may agree to refer the dispute either to:

a.) the International Center for Settlement of Investment Disputes (ICSID) under the rules of the International Convention on the Settlement of Investment Disputes between States and Nationals of other States opened for signature at Washington, D.C. on 18 March 1965, when such Contracting Party has become a party to the said Convention. As long as this requirement is not met each Contracting Party agrees the dispute may be settled under the rules of the

Additional Facility of the Administration of proceedings by the Secretariat of ICSID.

b) an ad hoc tribunal to be established under the arbitration rules of the United Nations Commission on International Trade Law (UNCITRAL). (grifos nossos) $)^{376}$.

Apesar dessa disponibilidade de opções, a tendência predominante ainda é permitir que o investidor escolha o fórum específico em que a disputa será resolvida. No entanto, alguns tratados, como o TBI entre Canadá e Costa Rica (1997), referem-se ao CIRDI, ao Mecanismo Complementar do CIRDI, e às regras da UNCITRAL, de forma subsidiária. Veja-se:

Article XII

Settlement of disputes between an investor and the host Contracting Party [...]

4. The dispute may be submitted to arbitration under:

(a) The International Centre for the Settlement of Investment Disputes (ICSID), established pursuant to the Convention on the Settlement of Investment Disputes between States and Nationals of other States, opened for signature at Washington D.C. on 18 March, 1965 ("ICISD Convention"), if both the disputing Contracting Party and the Contracting Party of the investor are parties to the ICISD Convention; or

(b) the Additional Facility Rules of ICISID, if either the disputing Contracting Party or the Contracting Party of the investor, but not both, is a party to the ICSID Convention; or

(c) and ad hoc arbitration tribunal established under the Arbitration Rules of the United Nations Commission on International Trade Law (UNCITRAL) in case neither Contracting Party is a member of ICSID, or if ICSID declines jurisdiction $^{377}$. (grifos nossos)

De acordo com o TBI entre Canadá e Costa Rica, permite-se o uso de um dos foros subsidiários somente se a primeira opção - CIRDI - não estiver disponível. No caso, se ao menos uma das partes não for membro do CIRDI ou se este declina de sua jurisdição.

376 TRATADO entre o Governo da República da Indonésia e o governo da República de Moçambique para a promoção e proteção de investimentos. Maputo, 26 de março de 1999. Disponível em: $<$ http://investmentpolicyhub.unctad.org/Download/TreatyFile/1628>. Acesso em: 29 set. 2015. art. VII.

${ }^{377}$ CANADÁ. Agreement Between the Government of Canada and the Government of the Republic of Costa Rica for the Promotion and Protection of Investments, San José, 18 de março de 1998. Disponível em: <http://www.treaty-accord.gc.ca/text-texte.aspx?id=101533 >. Acesso em: 29 set. 2015. art. XII, $\S 4$. 
Assim, o motivo principal para esse tipo de disposição é basicamente dar maior certeza às partes no que tange ao foro em que a disputa será conduzida ${ }^{378}$.

\subsubsection{Sentença Arbitral}

A sentença arbitral proferida pelo tribunal arbitral no CIRDI deve seguir alguns padrões formais, como ser emitida por escrito, conter a assinatura dos árbitros e ser motivada. Além disso, esta é definitiva e vinculante (final and binding) para as partes, não havendo a possibilidade de qualquer recurso, além de ser obrigatória não apenas para as partes da controvérsia, mas também para cada Estado Contratante ${ }^{379}$. No entanto, conforme os arts. 50, 51 e 52 da Convenção de Washington, há alguns procedimentos que ensejam a revisão da decisão arbitral.

O primeiro deles consiste no procedimento de interpretação da sentença arbitral, pelo que as partes poderão solicitar o esclarecimento da decisão e o pedido de interpretação será analisado pelo mesmo tribunal que a proferiu, não havendo prazo para a interposição do pedido. Caso não seja possível, um novo tribunal será composto, encarregado dessa função interpretativa. Esta revisão não afetará o caráter definitivo da sentença, além disso, ressalta-se que, como a sentença arbitral constitui res judicata, esta não será alvo de revisão, tampouco pelo procedimento de interpretação.

O segundo procedimento trata-se da revisão da sentença arbitral, em que o art. 51 da Convenção de Washington estabelece que para que haja revisão faz-se necessário que sejam descobertos novos fatos, desconhecidos pelas partes e pelo tribunal, surgidos após proferida a sentença, que possam ensejar na modificação da decisão ${ }^{380}$. Realizado após 90 dias da descoberta dos novos fatos, e no limite de três anos depois de proferida a sentença, o pedido será apresentado perante o tribunal que proferiu o laudo.

O terceiro trata-se da retificação, que poderá ser requerida por qualquer das partes 45 dias após o envio das cópias autenticadas às partes. Esse instituto trata da correção de erros materiais e omissões, não havendo devolução de matéria de mérito, e é analisado pelo

378 UNITED NATIONS CONFERENCE ON TRADE AND DEVELOPMENT. Bilateral Investment Treaties 1995-2006: Trends in Investment Rulemaking New York and Geneva: United Nations, 2007. p. 111.

${ }^{379}$ Quanto à publicidade, segundo o art. 48 (5) da Convenção de Washington, a decisão, total ou parcial, somente poderá se tornar pública se ambas as partes estiverem de acordo.

${ }^{380}$ REED, Lucy; PAULSSON, Jan; BLACKABY, Nigel. Guide to ICSID arbitration. 2nd. Alphen and den Rijn: Kluwer Law International, 2011. p. 159-160. 
próprio tribunal. No Mecanismo Complementar há previsão apenas da interpretação e retificação, nos arts. 55 e 56 do RAMC, não estando previstos a revisão, nem a anulação.

A sentença arbitral pode ser anulada, por meio de Comitê ad hoc nomeado pelo Conselho Administrativo a partir da lista de árbitros do Centro - ausentes os árbitros que compuseram o tribunal original ou árbitros que detenham mesma nacionalidade de qualquer dos árbitros anteriores, tampouco podendo ser da nacionalidade do Estado hospedeiro ou do investidor, não podendo ter sido indicados para a lista de árbitros por nenhum dos países envolvidos, nem atuado como conciliadores na mesma controvérsia. Isso ocorre, caso se enquadrem os seguintes requisitos: (i) vício na constituição do tribunal; (ii) a decisão ter sido proferida fora do âmbito de competência do tribunal (excès de pouvoir manifeste du tribunal); (iii) quando ocorrer corrupção por parte de algum dos membros do tribunal; (iv) quando houver descumprimento grave de alguma norma procedimental e (v) quando ausente motivação na sentença ${ }^{381}$. Ademais, o processo de anulação deve se iniciar em 120 dias da prolação do laudo arbitral, porém, se o caso envolver corrupção, 120 dias da descoberta do fato, com o prazo prescricional de três anos do laudo.

Procedendo algum dos motivos para a anulação, a sentença arbitral poderá ser anulada parcial ou integralmente. Segundo análise do ICSID Caseload-Statistics (Issued 2015-1), atualmente, o número de sentenças arbitrais anuladas na íntegra ou em parte contabilizam 13, sendo que a maior parte delas foi anulada entre 2001-2010 382 .

Quanto à execução da sentença arbitral, conforme o art. 54 da Convenção, os Estados, ao ratificarem o instrumento constitutivo, aceitam e reconhecem que a sentença proferida no âmbito do CIRDI deve ser executada em seus territórios nacionais, "como se sentenças arbitrais nacionais fossem"383. Assim, os Estados que ratificarem a Convenção de Washington, não poderão recusar-se a executar a sentença arbitral proveniente do CIRDI, mesmo com base nos preceitos de ordem pública local. Ademais, segundo o art. 27 da Convenção, ao aderir a esta, suspende-se o direito do exercício da proteção diplomática por

${ }^{381}$ CARREAU, Dominique; JUILLARD, Patrick. Droit international économique. 5ed. Paris: Dalloz, 2013. p. 596.

382 INTERNATIONAL CENTRE FOR SETTLEMENT OF INVESTMENT DISPUTES. ICSID Caseload-

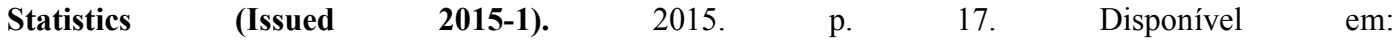
$<$ https://icsid.worldbank.org/apps/ICSIDWEB/resources/Documents/ICSID\%20Web\%20Stats\%2020151\%20(English)\%20(2)_Redacted.pdf>. Acesso em: 25 set. 2015.

${ }^{383}$ PUCCI, Adriana Noemi. Solução de Controvérsias Relativas a Investimentos Estrangeiros. 2003. 330f. Tese (Doutorado em Direito) - Faculdade de Direito da Universidade de São Paulo, São Paulo, 2003.p. 233. 
parte do Estado de origem do investidor, salvo se o Estado parte da controvérsia recusar-se a cumprir a sentença arbitral.

Entretanto, como salienta o doutrinador português Manuel Pereira Barrocas "nada impede que uma parte interessada, apesar do caráter auto executório da sentença arbitral proferida pelo ICSID, se socorra da Convenção de Nova Iorque para obter a execução de uma sentença arbitral proferida por aquela instituição"384. Ainda, nem todos os Estados que aderiram à Convenção de Washington designaram a entidade executante dos laudos e, mesmo para os Estados que indicaram pode ocorrer de não cumprirem a sentença de forma voluntária, resguardando-se por intermédio da imunidade de execução, prevista no art. 55 da Convenção. Nesse caso, a sanção pelo descumprimento acaba sendo mais política e econômica do que jurídica, e a "desconsideração do perfil moral do Estado faltoso quer no âmbito do Banco Mundial e do FMI, quer junto da banca internacional pode revelar alguma eficácia" ${ }^{385}$, apesar de existir uma pequena minoria de casos em que o descumprimento ocorra. Por fim, não há recurso no que se refere ao mérito da sentença arbitral do CIRDI.

\subsubsection{Situação Atual e Perspectivas}

Nos anos 1960, muitas nações latino americanas, preocupadas com a manutenção dos preceitos da doutrina Calvo, bem como com sua soberania econômica, optaram por negar a adesão à Convenção de Washington de 1965, o que ficou conhecido como o "não de Tóquio"386. Mais adiante, nos anos 1980 e 1990, em consonância com a sistemática do race to the bottom para a atração de investimentos e da onda de TBIs firmados, o cenário se alterou. Os Estados em desenvolvimento, incluindo os latino americanos, resolveram assinar tanto os TBIs quanto a Convenção, finalmente, abrindo as portas para o Direito Internacional dos Investimentos.

Ocorre que, nos anos 2000, muitos países foram demandados de forma intensa no CIRDI, como é o caso da Argentina - país mais demandado do Centro - tendo sido acionada em 51 casos. Desses, 19 casos estão em andamento, houve 9 condenações contra o país platino, 4 casos em que a reclamação dos investidores não procedeu e 19 casos encerrados por descontinuidade do processo, visto que os investidores retiraram os pedidos

\footnotetext{
${ }^{384}$ BARROCAS, Manuel Pereira. Manual de arbitragem. Coimbra: Almedina, 2010. p. 739.

${ }^{385}$ BARROCAS, Manuel Pereira. Manual de arbitragem. Coimbra: Almedina, 2010. p. 739.

${ }^{386}$ Excetuam-se a Guiana e a Guiana Francesa.
} 
ou houve acordo entre as partes. Diante disso, a Argentina tem envidado esforços para anular as sentenças arbitrais do CIRDI, recusando-se a cumpri-las por falta de homologação perante as cortes internas, pois estas somente poderiam ser executadas se iniciados procedimentos diante de seus tribunais ${ }^{387}$.

Como já exposto, as anulações das sentenças somente são consideradas na hipótese de vício na constituição do tribunal arbitral, excesso de poder do tribunal, corrupção de um dos árbitros, não observância de regra procedimental essencial ou ausência de motivação. Nesse contexto, somente no caso Sempra Energy International $v$. Argentina $^{388}$ a sentença arbitral contra a Argentina foi anulada em função de excessos de poder do tribunal. Nos outros casos analisados, se chegou à conclusão de que elas não eram passíveis de anulação, o que fez a Argentina negar-se a efetuar os pagamentos devidos. Após um período de negociações, este país acordou em realizar pagamentos por meio de títulos de sua dívida pública, porém, com valores aproximados aos devidos. Todo esse imbróglio coloca em cheque, até hoje, se o governo argentino conseguirá honrar as decisões arbitrais proferidas pelos tribunais de investimentos.

Somado a isso, alguns países latino americanos acabaram por se retirar do sistema CIRDI e a denunciar seus TBIs, como é o caso de Bolívia (2007), Equador (2009) e Venezuela (2012), alegando que esses violavam suas Constituições nacionais, que foram alteradas pelos governos recém-assumidos à época da alteração, retomando preceitos de que as disputas concernentes a investimento devem manter-se no âmbito dos tribunais internos e refutando os foros internacionais para a resolução de litígios sobre investimentos. Isso, pois, esse sistema possibilitaria a ingerência de um sistema internacional que privilegia o investidor e afastaria os interesses estatais desses países. Ademais, ressalta-se que esses países também têm sido demandados perante o CIRDI $^{389}$.

Apesar disso, o CIRDI continua sendo o principal foro para a solução de controvérsias sobre investimentos e, isso se dá, apesar das críticas quanto à sua transparência e imparcialidade, em razão de seu corpo institucional qualificado e que possibilita legitimidade processual ativa tanto para Estados, quanto para entidades privadas, sem depender do consentimento de suas nações. As demandas no Centro

${ }^{387}$ Ressalta-se que muitos dos casos argentinos estão ligados às medidas cambiais adotadas pela argentina durante a crise econômica do início dos anos 2000.

${ }^{388}$ INTERNATIONAL CENTRE FOR SETTLEMENT OF INVESTMENT DISPUTES. Sempra Energy International v. The Argentine Republic, ICSID Case n. ARB/02/16, Award. 28 Sep. 2007.

389 COSTA, José Augusto Fontoura. Proteção internacional do investimento estrangeiro no MERCOSUL. Florianópolis: GEDAI, 2012. p. 12. ALVAREZ, José E. The return of the State. Minnesota Journal of International Law, Minneapolis, Minn, v. 20, n. 2, p. 223-2264, 2011. p. 239. 
iniciaram-se de forma tímida, tendo sido alavancadas principalmente a partir dos anos 2000, atingindo seu auge em 2012 e, alcançando o patamar total de 497 casos em dezembro de 2014, envolvendo tanto a Convenção de Washington, quanto o Mecanismo Complementar. Desses casos, a imensa maioria é de arbitragens CIRDI (442 casos), seguidos por 46 casos de arbitragem via Mecanismo Complementar, 7 casos de conciliação respaldadas na Convenção de Washington e 2 casos de conciliação por meio do Mecanismo Complementar. Essas informações podem ser observadas nos gráficos abaixo:

\section{Gráfico 2 - Número de casos registrados nos termos da Convenção CIRDI e das Regras do Mecanismo Complementar por Ano}

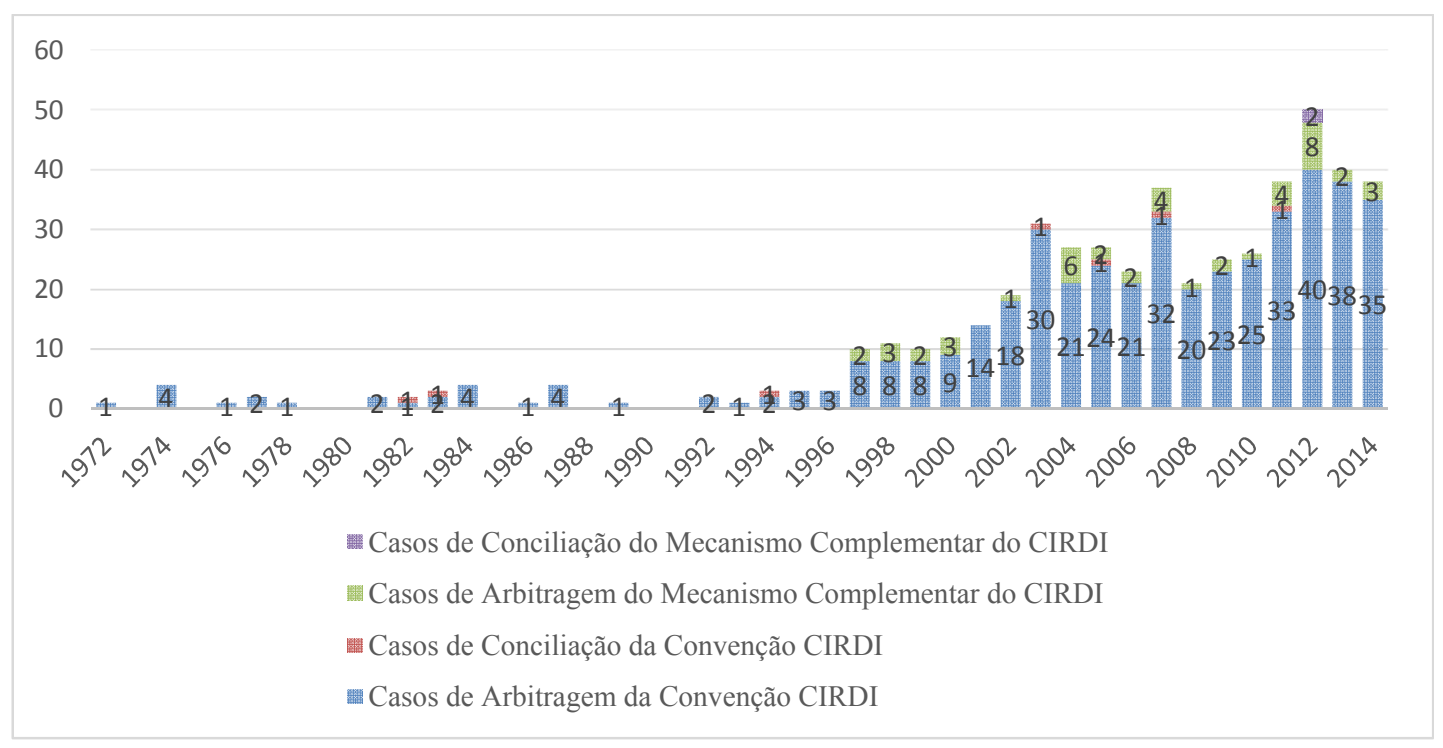

Fonte: ICSID Caseload-Statistics (Issued 2015-1) 


\section{Gráfico 3 -Tipo de casos registrados nos termos da Convenção CIRDI e das Regras do Mecanismo Complementar}

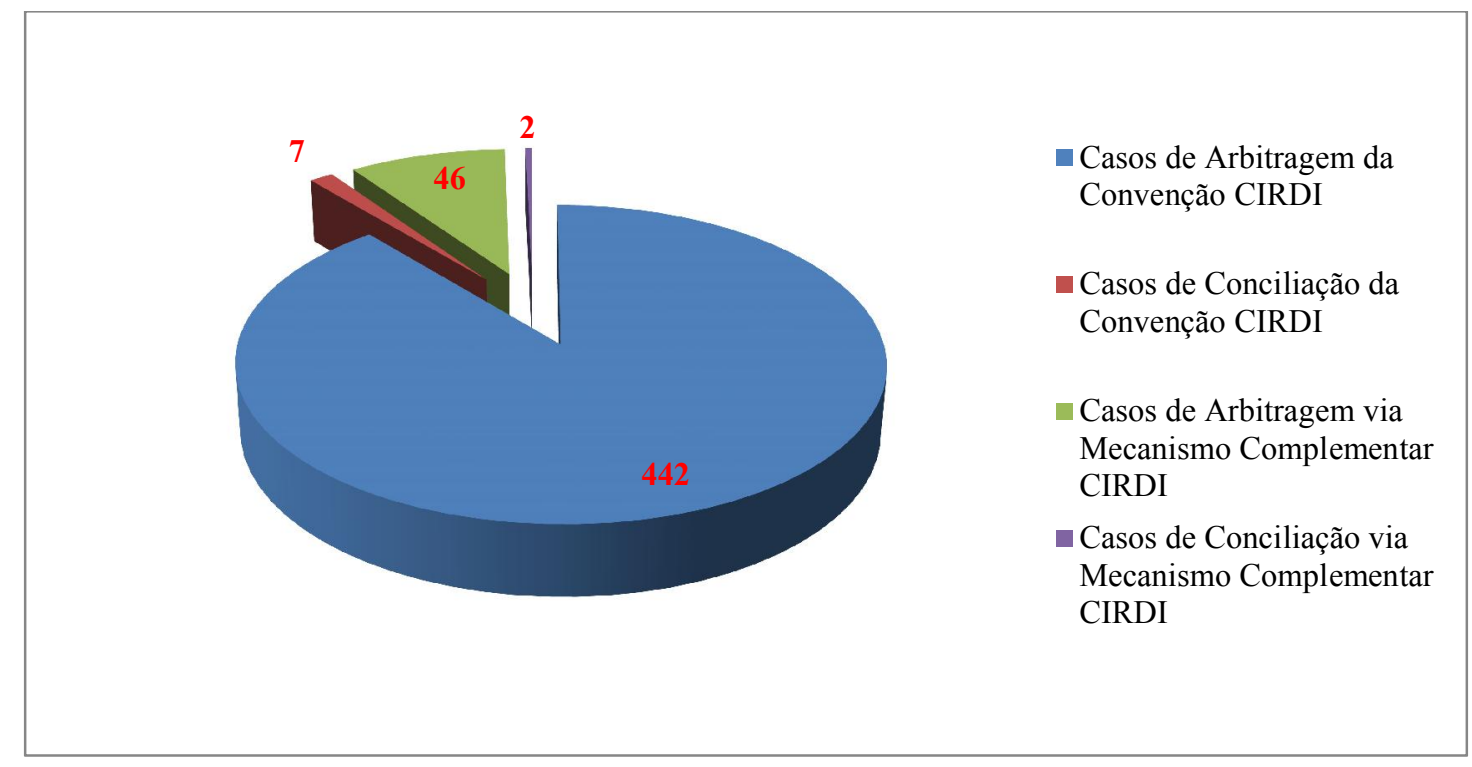

Fonte: ICSID Caseload-Statistics (Issued 2015-1)

No ano de 2015, conforme disponibilizado no sítio eletrônico do CIRDI, já foram registrados 41 casos, sendo que a Espanha, por enquanto, tem sido o país mais demandado no ano, com um total de 12 reclamações. Ademais, há ainda um caso de arbitragem registrado sob os auspícios do Mecanismo Complementar (Strabag SE v. Libya) e uma arbitragem em que as regras aplicáveis são as da UNCITRAL (A11Y LTD. v. Czech Republic $)^{390}$.

\subsubsection{Posição Brasileira}

No início dos anos 1960, foi engendrada a Convenção de Washington de 1965, tratado internacional que criou o Centro Internacional Para Resolução de Disputas sobre Investimentos. Como exposto anteriormente, o Centro formalizaria institucionalmente o mecanismo da arbitragem mista investidor-Estado como meio preferível à solução de controvérsias entre Estados soberanos e entidades privadas. Diante desse fenômeno jurídico mundial, ao Brasil era necessário se manifestar sobre a adesão ou rejeição a essa

${ }^{390}$ INTERNATIONAL CENTRE FOR SETTLEMENT OF INVESTMENT DISPUTES. Cases. Disponível em: <https://icsid.worldbank.org/apps/ICSIDWEB/cases/Pages/AdvancedSearch.aspx>. Acesso em: 5 out. 2015. 
nova sistemática proposta pelo Banco Internacional para a Reconstrução e o Desenvolvimento (BIRD).

Segundo parecer do então Consultor Jurídico do Ministério das Relações Exteriores, Augusto de Rezende Rocha, proferido em 20 de agosto de 1964, o governo brasileiro demonstrou posicionamento claramente contrário à adesão ao órgão de arbitragem internacional. Dentre as principais alegações do Consultor Jurídico do Itamaraty, estão a de que frente a existência de órgãos internacionais, tais como a Organização das Nações Unidas (ONU), o BIRD não se trata do organismo mais adequado para se institucionalizar procedimento arbitral com o intuito de dirimir litígios entre Estados e investidores "supostamente desprotegidos". Além disso, de acordo com a opinião jurídica de Augusto Rocha (1964):

[...] não é crível que qualquer Estado normalmente organizado - isto é, de acordo com o constitucionalismo propagado e fortalecido a partir do sec. XX apresentando instituições asseguradoras de uma ordem jurídica primária, concorde de boa mente em sub-rogar funções públicas essenciais a um tribunal internacional, que na sua organização e funcionamento será passível de sofrer influências prejudiciais à própria soberania desse Estado $[\ldots]^{391}$.

O consultor jurídico ainda complementa que "nunca o Governo brasileiro, em qualquer época, deixou de acolher, diplomática ou judicialmente, as reivindicações de meritorious cases de estrangeiros que lhe fossem apresentadas" ${ }^{\prime 392}$ e esta submissão não traria maiores vantagens "a instrumentalidade judiciária de qualquer país"393.

Ademais, aduziu-se à época que a proliferação de mecanismos arbitrais independeria de institucionalização, podendo as sentenças arbitrais proferidas, quando estas não fossem sustentadas por princípios jurídicos universais ${ }^{394}$, concorrer para fomentar a desconfiança no que tange às imunidades dos árbitros às "injunções políticas ou econômicas" 395 . Por fim, complementou-se que esta seria a "consagração do imperialismo econômico e financeiro, ainda que disfarçada" ${ }^{396}$, pois o CIRDI "consagra e quase institucionaliza o estado de tensão, tão difícil de erradicar e, relações políticas

\footnotetext{
${ }^{391}$ ROCHA, Augusto de Rezende. Parecer DAJ/138: criação de órgão de arbitragem internacional - BIRD. 20 ago. 1964. item 17, II.

392 ROCHA, Augusto de Rezende. Parecer DAJ/138: criação de órgão de arbitragem internacional - BIRD. 20 ago. 1964. item 16.

${ }^{393}$ ROCHA, Augusto de Rezende. Ibid., item 17, II.

${ }^{394}$ XAVIER JÚNIOR, Ely Caetano. Direito internacional dos investimentos e o Brasil: uma perspectiva a partir do padrão de tratamento justo e equitativo. 2014. 279 f. Dissertação (Mestrado em Direito). Faculdade de Direito da Universidade Estadual do Rio de Janeiro, Rio de Janeiro, 2014, p.109.

395 ROCHA, Augusto de Rezende. op.cit., item 17, IV.

${ }^{396}$ ROCHA, Augusto de Rezende. op.cit., item 17.I.
} 
internacionais, existentes entre as economias dominantes e as econômicas dominadas" ${ }^{\text {397, }}$ posicionamento de fundo ideológico que preponderou ao final.

Desse modo, atualmente, a posição brasileira é de resistência ${ }^{398}$, apesar desta ter saído de foco à época da assinatura dos TBIs brasileiros nos anos 1990, em que havia nos acordos a previsão de arbitragem de investimentos. No entanto, com os Acordos de Cooperação e Facilitação de Investimentos (ACFIs) assinados em 2015, essa objeção retorna, como será melhor discutido no capítulo seguinte. Ademais, ressalta-se que, atualmente, esse posicionamento torna-se estranho face à boa experiência do país no que tange à Lei $n^{\circ}$ 9.607/96 e à arbitragem comercial, à aceitabilidade pelo Judiciário nacional da arbitragem, à afirmação do Supremo Tribunal Federal (STF) pela sua constitucionalidade e à adesão à Convenção de Nova Iorque de 1958 em 2002, para a homologação de sentenças arbitrais estrangeiras. Nesse diapasão, esses elementos fazem com que o argumento de oposição à arbitragem internacional não mais se sustente, e, diante da expansão dos investimentos brasileiros no exterior, urge-se que estes alcancem maior proteção ${ }^{399}$, em particular, no que tange ao acesso aos mecanismos jurisdicionais de solução de controvérsias por meio da arbitragem investidor-Estado.

\subsubsection{As Regras de Arbitragem da UNCITRAL}

A Comissão das Nações Unidas para o Direito Comercial Internacional (UNCITRAL) ${ }^{400}$ foi instituída pela Resolução 2205 (XXI), de 17 de dezembro de 1966 da Assembleia Geral das Nações Unidas (AGNU). Ao estabelecer a Comissão, a Assembleia Geral reconheceu que as disparidades entre as legislações nacionais, regentes do comércio internacional, criam obstáculos para o fluxo comercial mundial. As Nações Unidas, por meio da UNCITRAL, portanto, deve desempenhar um papel mais ativo para reduzir ou eliminar esses obstáculos. Assim sendo, a Assembleia Geral deu à Comissão o mandato

${ }^{397}$ ROCHA, Augusto de Rezende. Parecer DAJ/138: criação de órgão de arbitragem internacional - BIRD. 20 ago. 1964, item 18.

${ }^{398}$ Segundo Carmen Tibúrcio, o Brasil o único país da América do Sul que não ratificou a Convenção de Washington. Cf. TIBÚRCIO, Carmen. Arbitragem de investimento no Brasil In: RIBEIRO, Marilda Rosado de Sá (Org.) Direito Internacional dos Investimentos. Rio de Janeiro: Renovar, p. 233-270, 2014. p. 239.

399 COSTA, José Augusto Fontoura. Brasil e arbitragem internacional de investimentos: realidade e possibilidades. In: RIBEIRO, Marilda Rosado de Sá. Direito internacional dos investimentos. Rio de Janeiro: Renovar, pp.247-270, 2014, p.269. TIBÚRCIO, Carmen. A arbitragem no direito brasileiro: o histórico e lei 9.307/96. Revista de Processo, São Paulo, São Paulo, v. 104, 2001. p.79-99.

${ }^{400}$ Optou-se pela nomenclatura em inglês pelo uso mais frequente na doutrina. 
geral para promover a harmonização progressiva e unificação do direito do comércio internacional.

A UNCITRAL é formada por 60 membros eleitos pela AGNU, provenientes das mais distintas regiões e sistemas econômicos e jurídicos do globo, com mandato de 3 ou 6 $\operatorname{anos}^{401}$. A Comissão desempenha funções como a elaboração de leis-modelo, convenções internacionais e regras e regulamentos em comércio internacional, com especial destaque para o trabalho que resultou na Convenção sobre Reconhecimento e Execução de Sentenças Arbitrais Estrangeiras, a Convenção de Nova Iorque de 1958, a Convenção das Nações Unidas sobre Contratos de Compra e Venda Internacional de Mercadorias, de 1980, e as Regras de Arbitragem da UNCITRAL.

No que concerne ao Direito dos Investimentos, as Regras da UNCITRAL desempenham papel fundamental, haja vista que estas estão previstas em uma série de tratados de investimentos, seja como mecanismo principal de solução de controvérsias, seja como meio subsidiário à arbitragem CIRDI. Essas regras foram instituídas pela Resolução 31/98 da AGNU, de 15 de dezembro de 1976, passando a ser utilizadas seja nas arbitragens comerciais internacionais, seja nas arbitragens mistas investidor-Estado ad hoc. No entanto, faz-se necessário ressaltar que a arbitragem mista realizada pelas regras da UNCITRAL não se trata de arbitragem institucional, apesar de aplicadas nos procedimentos ad hoc ou na complementação de sistemas institucionais, como o sistema CIRDI. Está a rigor das partes prover um quadro administrativo para cada caso, criando um tribunal ad hoc para este em qualquer lugar do mundo. Contudo, há a possibilidade de as Regras serem aplicadas por uma instituição reconhecida, como o CIRDI ou a $\mathrm{CCI}^{402}$.

Ademais, as Regras da UNCITRAL foram revistas em 2010, e incluem disposições relativas a, dentre outros temas, múltiplas partes na arbitragem e a incidência de litisconsórcio passivo, bem como a responsabilidade e um procedimento de objeção aos peritos nomeados pelo tribunal arbitral. Ressalta-se que uma série de características inovadoras se encontram previstas nessa normativa, com o objetivo de reforçar a eficiência processual, incluindo os procedimentos de revisão para a substituição de um árbitro, a exigência de razoabilidade dos custos, um mecanismo de revisão a respeito dos custos da arbitragem e, também, disposições pormenorizadas sobre medidas provisórias.

${ }^{401}$ UNITED NATIONS COMMISSION ON INTERNATIONAL TRADE LAW. Origin, Mandate and Composition of UNCITRAL. Disponível em: $<\mathrm{http}: / / \mathrm{www}$.uncitral.org/uncitral/en/about/origin.html . Acesso em: 30 set. 2015.

${ }^{402}$ DOLZER, Rudolf; SCHREUER, Christoph. Principles of international investment law. Oxford: Oxford University Press, 2008. p. 226. 
Em 2013, com a aprovação do Regulamento da UNCITRAL sobre Transparência em Tratados Baseados em Arbitragem Investidor-Estado (mais conhecidas como Regras sobre Transparência), uma nova redação do art. $1, \S 4^{\circ}$ foi adicionada ao texto das Regras de Arbitragem (tal como revisto em 2010), prevendo a incorporação das Regras de Transparência da UNCITRAL em arbitragens investidor-Estado iniciadas em conformidade com tratados de investimento celebrado a partir de $1^{\circ}$ de abril de $2014^{403}$. Estas previsões tratam-se de regras cogentes automaticamente incluídas nas regras de arbitragem da UNCITRAL e sua relevância reside, principalmente, na publicidade das arbitragens mistas. Isso, pois, preliminarmente à criação dessas normas, as controvérsias regidas pelas regras da UNCITRAL não eram públicas, "sequer no nível mais básico, isto é, o de deixar o público saber da existência da controvérsia que estabelece obrigações como acesso à informação e documentos concernentes às disputas e a participação de amicus curiae" ${ }^{404}$. Assim, em todos os outros aspectos, as Regras de Arbitragem da UNCITRAL de 2013 (com a incorporação das normas de transparência) permanecem inalteradas desde a versão revista em $2010^{405}$.

Ressalta-se que, apesar de não se tratar de convenção internacional e não criar limites ou obrigações para os Estados, o consentimento é essencial para sua aplicabilidade ${ }^{406}$, mesmo as normas sendo meramente dispositivas. Ademais, as regras da UNCITRAL "não contam com nenhuma autoridade empenhada em seu cumprimento" ${ }^{407} \mathrm{e}$, conforme disposto nos arts. 6(2) e 7(2), "b" e (3), em última instância, o demandante poderá acionar o Presidente da Corte Permanente de Arbitragem (CPA), para que aponte uma autoridade que indique o árbitro faltante ${ }^{408}$.

Ainda, importante destacar que em 2014, a Assembleia Geral da UNCTAD aprovou a Convenção sobre Transparência em Tratados Baseados em Arbitragem Investidor-Estado, com foco em aplicar tais disposições aos acordos já existentes regidos

\footnotetext{
${ }^{403}$ UNITED NATIONS CONFERENCE ON TRADE AND DEVELOPMENT. Recent trends in IIAs and ISDS, n.1. Genebra: United Nations, 2015. p. 8.

${ }^{404}$ SCHLEE, Paula. Transparência em arbitragens internacionais investidor estado. Revista da Secretaria do Tribunal Permanente de Revisão, Assunción, ano 3, n. 5, .95-113, 2015. p.106. Disponível em: $<$ http://www10.iadb.org/intal/intalcdi/PE/2015/15365.pdf > Acesso em: 24 maio 2015.

${ }^{405}$ UNITED NATIONS COMMISSION ON INTERNATIONAL TRADE LAW. UNCITRAL Arbitration Rules. Disponível em: $<$ http://www.uncitral.org/uncitral/en/uncitral_texts/arbitration/2010Arbitration_rules.html>. Acesso em: 30 set. 2015.

${ }^{406}$ COSTA, José Augusto Fontoura. Direito Internacional do Investimento Estrangeiro. Curitiba: Juruá, 2010. p. 201.

${ }^{407}$ COSTA, José Augusto Fontoura. Ibid., p. 201.

${ }^{408}$ COSTA, José Augusto Fontoura. Ibid., p. 201.
} 
sob a égide das regras da UNCITRAL - que hoje simbolizam cerca de quase um terço das arbitragens $^{409}$.

Por fim, as regras da UNCITRAL tratam-se do segundo conjunto de diretrizes arbitrais investidor-Estado mais utilizado. Esses procedimentos sob a égide da UNCITRAL possuem vantagem quanto ao seu suporte institucional, por exemplo, pois as arbitragens são administradas pela Corte Permanente de Arbitragem (CPA), com sede em Haia, e algumas também são administradas pelo Secretariado do $\mathrm{CIRDI}^{410}$.

\subsubsection{Câmara de Comércio Internacional (CCI)}

A Câmara de Comércio Internacional (CCI) trata-se de organização privada, com sede em Paris, fundada em 1923 e constituída no âmbito do direito interno, responsável por administrar procedimentos arbitrais internacionais, com partes de nacionalidades diversas. Esta consiste na mais renomada e antiga câmara de resolução de conflitos comerciais verdadeiramente internacional do mundo. É composta por 77 membros de 77 países e de todos os continentes, sendo a instituição para a resolução de litígios com maior representatividade mundial. Apesar de seu foco ser majoritariamente na arbitragem comercial internacional, a CCI também admite a arbitragem de investimentos em sua seara, inclusive, dando abertura à utilização de procedimentos de mediação.

A CCI não é uma corte propriamente dita, mas uma instituição com um corpo de árbitros que garante a aplicação das Regras de Arbitragem da Câmara de Comércio Internacional, editadas pelo próprio órgão. Esta tem como funções primordiais prover assistência técnica e uma lista de árbitros, porém, não propriamente realiza julgamentos ou profere sentenças. A CCI irá confirmar os árbitros indicados com as partes, e caso as partes decidam em contrário, irá nomear os respectivos árbitros para o caso.

Ademais, uma característica dos procedimentos da CCI corresponde aos Termos de Referência, preparados pelos árbitros, vez que recebem os arquivos dos casos do Secretariado da CCI. Estes termos corresponderão a uma curta caracterização do caso, com resumo e pontos principais e, em especial, uma lista de questões a serem decididas. Esses pontos, além de facilitarem o foco do tribunal arbitral no momento do procedimento

\footnotetext{
${ }^{409}$ PANZINI, Fabrizio; NEGRI, Constanza. O retorno dos acordos de investimentos na agenda comercial brasileira. Revista Brasileira de Comércio Exterior, ano 29, p. 58-72, abr.jun. 2015. p. 65.

${ }^{410}$ UNITED NATIONS CONFERENCE ON TRADE AND DEVELOPMENT. Investor-State dispute settlement: UNCTAD Series on issues in international investment agreements II. New York; Geneva: United Nations, 2014. $\quad$ p. $67 . \quad$ Disponível $\quad$ em: $<$ http://unctad.org/en/PublicationsLibrary/diaeia2013d2_en.pdf >. Acesso em: 3 out. 2015.
} 
arbitral, reflete uma impressão preliminar do tribunal e das questões que irão se desenvolver durante os procedimentos.

Outra característica do procedimento sob a égide da CCI trata-se do modo como uma sentença é adotada, visto que após o tribunal acordar na realização de uma primeira versão da sentença arbitral, este documento, então, será encaminhado à Corte de Arbitragem da CCI, que checará os requisitos formais, garantindo que todos os pontos relevantes foram cobertos, bem como requisitos formais. Porém, a responsabilidade para a substância da sentença ainda é remetida ao tribunal arbitral, e não à Corte ${ }^{411}$.

\subsubsection{Câmara de Comércio de Estocolmo (CCE)}

O Instituto de Arbitragem da Câmara de Comércio de Estocolmo (CCE) foi estabelecido em 1917, como uma entidade autônoma da CCE, que detém Secretaria e Conselho próprios. Durante os anos 1970, no auge da Guerra Fria, a Câmara de Comércio passou a ser utilizada com mais frequência principalmente em controvérsias entre os soviéticos e empresas privadas ocidentais, tendo reconhecida por entidades do bloco oriental como espaço neutro para a resolução de conflitos de cunho comercial e ganhado notoriedade ${ }^{412}$.

Após o colapso da União Soviética e até meados de 2006, mais de uma dúzia de casos de arbitragem investidor-Estado tinham sido registradas na CCE, todas envolvendo demandados advindos da Comunidade de Estados Independentes ou da região do Báltico. Exemplo disso foi um arranjo conhecido como US/USSR Optional Clause Agreement (1977), que é baseado em cartas datadas de 29 de dezembro de 1976 entre a Associação de Arbitragem Americana e a Câmara de Comércio da União Soviética, em que a CCE foi designada como appointing authority e a inclusão da Optional Clause fora considerada aceitável em contratos entre pessoas físicas ou jurídicas americanas e organizações comerciais estrangeiras da URSS. Posteriormente, o governo chinês também demonstrou grande simpatia na escolha da CCE como alternativa à arbitragem com a China.

$\mathrm{O}$ fato de a CCE apresentar motivação restrita à anulação de sentenças arbitrais, bem como as facilidades e as Regras de Arbitragem próprias também fomentam a aceitabilidade do Instituto de Arbitragem da CCE para as partes contratantes, conquistando

${ }^{411}$ DOLZER, Rudolf; SCHREUER, Christoph. Principles of international investment law. Oxford: Oxford University Press, 2008. p. 226-227.

${ }^{412}$ ALLEY, Edwin R. International Arbitration: The Alternative of the Stockholm Chamber of Commerce. The International Lawyer. v. 22, n. 3, p. 837-844, 1988. p. 
respeitabilidade perante o cenário internacional. O sucesso da CCE se deu, também, pela tradição de neutralidade da Suécia e de sua tradição legal na arbitragem. Além disso, com o aumento das arbitragens mistas sob a égide do Tratado da Carta da Energia, que prevê a resolução de litígios através da Câmara de Comércio de Estocolmo, a arbitragem de investimentos conquistou uma parcela considerável dos casos da $\mathrm{CCE}^{413}$.

\subsection{A TEORIA DA SOMBRA DO DIREITO E SUA UTILIDADE PARA O DIREITO}

Em que pese o modo judicial de resolução de disputas tratar-se do meio mais tradicional para que se possa alcançar a solução adequada das controvérsias aventadas e ensejar a "vindicação efetiva de direitos" "114, este "deve ser visto como uma das formas dentro de um universo de alternativas parcial ou totalmente direcionadas aos mesmos fins” ${ }^{\$ 15}$. Isso, pois, a resolução de disputas através da adjudicação, aqui referida como a "atividade pela qual um terceiro, estranho às partes, analisa o caso, indicando uma solução com força imperativa" ${ }^{\$ 16}$ e pondo fim ao conflito existente através da aplicação da norma ao caso concreto não é a única forma admissível ao propósito da pacificação das relações sociais.

Além dos processos adjudicatórios, existem também os meios alternativos de resolução de disputas, processos consensuais em seu resultado, que propiciam uma ordenação de ações objetivas para que as partes se predisponham a efetuar um acordo. A raison d'être dos métodos não judiciais traduz, em primeiro lugar, de forma histórica, o movimento universal de acesso à justiça, de modo a "superar dificuldades ou obstáculos que fazem inacessíveis para tanta gente as liberdades civis e políticas»"417. Em segundo lugar, esses mecanismos alternativos se constituem como medidas de substituição ou de

${ }^{413}$ DUGAN, A.; WALLACE, D.; RUBIN, N.; SABAHI, B. Investor-state arbitration. Oxford: Oxford University Press, 2008. p.79.

${ }^{414}$ CAPPELLETTI, Mauro. Os métodos alternativos de solução de conflitos no quadro do movimento universal de acesso à justiça., São Paulo, São Paulo, ano 19, n. 74, p.82-97, 1994. p. 87.

${ }^{415}$ SALLES, Carlos Alberto de. Mecanismos alternativos de solução de controvérsias e acesso à justiça: a inafastabilidade da tutela jurisdicional recolocada. In: FUX, Luiz; NERY JR., Nelson; WAMBIER, Teresa Arruda Alvim (Coord.). Processo e Constituição: Estudos em homenagem aos Professor José Carlos Barbosa Moreira. São Paulo: Editora Revista dos Tribunais, p.779-792, 2006. p. 784.

${ }^{416}$ SALLES, Carlos Alberto de. Mecanismos alternativos de solução de controvérsias e acesso à justiça: a inafastabilidade da tutela jurisdicional recolocada. In: FUX, Luiz; NERY JR., Nelson; WAMBIER, Teresa Arruda Alvim (Coord.). Processo e Constituição: Estudos em homenagem aos Professor José Carlos Barbosa Moreira. São Paulo: Editora Revista dos Tribunais, p.779-792, 2006. p. 786.

417 CAPPELLETTI, Mauro. Os métodos alternativos de solução de conflitos no quadro do movimento universal de acesso à justiça., São Paulo, São Paulo, ano 19, n. 74, p.82-97, 1994. p. 83. 
apoio aos meios judiciais ${ }^{418}$. Em terceiro lugar, esses meios fornecem um quadro normativo em que as partes podem determinar livre e pacificamente seus direitos e responsabilidades. Esse processo, portanto, pelo qual as partes encontram-se empoderadas em criar seus próprios compromissos hábeis a serem cumpridos, antes que se chegue ao julgamento pelas cortes, consiste em uma forma de mobilização da ordem privada (private ordering).

Nesse diapasão, a doutrina internacional que versa sobre negociação desenvolveu, no final da década de 1970, a teoria da sombra do direito. Robert H. Mnookin e Lewis Kornhauser, respectivamente professores da Harvard Law School e da New York University School of Law, por meio de artigo intitulado Bargaining in the Shadow of the Law: The Case of Divorce ${ }^{419}$, partem do seguinte questionamento: como as regras e procedimentos usados pelas cortes na adjudicação afetam o processo de negociação que ocorre entre as partes fora do judiciário?

Para responder a essa indagação, os autores partem da análise mais aprofundada do sub-ramo do Direito de Família, com a finalidade de examinar o impacto dos sistemas legais nas negociações e barganhas que ocorrem antes do julgamento pelos tribunais estatais, na expectativa dos futuros resultados provenientes de um meio judicial de solução de controvérsias. As partes, racionalmente, farão um prognóstico do resultado caso o litígio prossiga para o judiciário e, antes que isso ocorra, poderão optar em promover a negociação (pre-trial bargaining), de modo a deixar ambos os lados em melhor situação, dividindo os custos de transação $0^{420}$. Contudo, a incerteza sobre a preferência de cada um dos lados encoraja as partes a firmarem um acordo, através de um sistema de negociação e do oferecimento de propostas e contrapropostas antes que a disputa judicial ocorra. Ou seja, a ameaça de um futuro julgamento e de seus possíveis resultados afetam a dinâmica de negociação ${ }^{421}$. Assim, a probabilidade de convencimento em um julgamento e a probabilidade de uma sentença após findo o processo é largamente determinada pelo período de negociações ${ }^{422}$.

Como exposto anteriormente, o método clássico da sombra do direito proposto por Mnookin e Kornhauser parte do Direito de Família Americano, em que a lei de

\footnotetext{
${ }^{418}$ SALLES, Carlos Alberto de. op.cit., p.780.

${ }^{419}$ MNOOKIN, Robert H.; KORNHAUSER, Lewis. Bargaining in the shadow of the laws: the case of divorce. v. 88, Yale Law Journal, 1979, p. 950-997.

${ }^{420}$ BIBAS, Stephanos. Plea bargaing outside the shadow of trial. Harvard Law Review. v.117, n. 8, 2004, p. 2464.

${ }^{421}$ POLETTI, Arlo; DE BIÈVRE, Dirk; CHATAGNIER, J. Tyson. Cooperation in the shadow of wto law: why litigate when you can negotiate. Working Paper, p. 1-23, 3/2014.

${ }^{422}$ BIBAS, Stephanos. op.cit.., p. 2465.
} 
divórcio possibilita que os casais criem seus próprios compromissos executáveis ${ }^{423}$, é mencionado como uma forma de ordem privada (private ordering), um poder que deve ser concedido às partes para resolverem as questões que se levantam. Segundo os doutrinadores, tanto nos Estados Unidos quanto na Inglaterra, a esmagadora maioria dos casais que se divorciam resolvem questões jurídicas como distribuição do patrimônio, pensão alimentícia, guarda e custódia dos filhos sem levar qualquer questão controvertida às cortes para adjudicação. Entretanto, a dúvida paira sobre qual é o limite das partes (ou o grau concedido às partes) em realizar seu próprio compromisso executável através de acordos privados.

Conforme aduzem os autores, o poder das partes em determinar o divórcio e suas futuras consequências depende se há filhos pequenos provenientes do respectivo matrimônio. Isso, pois, quando existem crianças envolvidas, em função da primazia do interesse do menor, as partes não possuem tanta liberdade para criar seus arranjos negociais, ou seja, essas podem criar seus próprios compromissos, porém, o juiz não tem a obrigação de executá-los, pois deve sempre se ater ao que melhor servirá à criança.

Nesse diapasão, no geral, as reais motivações para se conceder amplos poderes aos casais para que realizem seus próprios acordos são as mais diversas, tais como: (i) minimização dos custos financeiros da litigância perante os tribunais tanto para as partes privadas, quanto para a ordem pública; (ii) evitar-se os riscos e incertezas da litigância (que envolverão situações de tudo ou nada) por meio de acordo negociado; (iii) economizar tempo por meio da celebração de acordos, o que permitirá que cada cônjuge siga em frente o mais rápido possível com sua própria vida; (iv) pressupor que uma solução consensual será provavelmente mais consistente, pois deterá as preferências de cada cônjuge e, portanto, será mais aceitável ao longo do tempo do que uma decisão imposta por uma corte.

Ocorre que, para os criadores da teoria da sombra do direito, mesmo quando se há crianças envolvidas, ainda a melhor solução é a negociada entre os cônjuges, visto que um acordo entre as partes preserva relações sociais e psicológicas da criança com os pais, bem como estes, por sua situação, têm mais conhecimento sobre como são as crianças do que a figura do juiz, o que preservaria melhor as circunstâncias e desejos dos menores.

\footnotetext{
${ }^{423}$ Mnookin e Kornhauser destacam que existem vários graus de ordem privada sobre a dissolução de um casamento, que foram sendo conquistados após diversas mudanças na lei do divórcio americana na década de 1970, tornando o divórcio uma questão de preocupação privada.
} 
Mas como o sistema judicial afeta o comportamento de negociação ou barganha das partes? Sempre será possível que as partes negociem resultados que as façam se encontrar em situação melhor do que se encontrariam caso simplesmente aceitassem os resultados que as cortes as tivessem imposto. $\mathrm{O}$ resultado das cortes não necessariamente é simples ou direto, havendo uma gama de resultados possíveis. Entretanto, há um poder legal envolvendo os institutos a serem discutidos, que não podem ser medidos com tanta precisão, o que provém um pano de fundo para o processo de barganha, que é rodeado de incerteza.

Os pais que estão se divorciando não irão negociar sobre a divisão do patrimônio e as prerrogativas de custódia do filho em um vácuo jurídico, irão negociar na sombra da lei. Ora, as normas jurídicas sobre pensão alimentícia, sobre patrimônio e custódia dão a cada um dos cônjuges determinados fundamentos com base em o que cada um iria receber se o caso fosse a julgamento. Em outras palavras, o resultado que a lei imporá, caso não haja acordo, dá a cada um dos pais uma moeda de troca, o que possibilitará a negociação. Nas negociações no âmbito da sombra da lei, nenhum dos cônjuges iria concordar com uma divisão que ele ou ela perceba ser pior para si próprio do que o resultado obtido levando o caso ao judiciário. Desse modo, qualquer avaliação pelas partes deve considerar o tempo e os custos dos procedimentos judiciais, juntamente com o possível impacto da decisão sobre a relação entre as partes ${ }^{424}$.

Assim sendo, as partes negociarão um acordo na sombra dos resultados esperados em um possível julgamento e o direito aplicado influenciará as expectativas das partes sobre o que elas irão ganhar ao optarem por recorrer ao judiciário estatal ou à arbitragem, considerados também os custos, ao invés de depender de negociação que não seja tão favorável. Essa opção, caso o meio negociado se mostre ineficiente, é tida pela teoria da negociação baseada em interesses, desenvolvida por Fischer e Ury, como better alternative to a negotiated agreement (BATNA) ${ }^{425}$. O BATNA mostra-se como uma alternativa concreta à resolução negociada quando não há acordo, contudo, caso a sombra do direito seja pálida e fraca, negociar-se-á com "os olhos fechados", visto que não se saberá com certeza os resultados caso se opte pela solução não negociada. Por isso, faz-se

\footnotetext{
${ }^{424}$ MNOOKIN, Robert H.; KORNHAUSER, Lewis. Bargaining in the shadow of the laws: the case of divorce. Yale Law Journal, v. 88, p. 950-997, 1979. p. 968-969.

${ }^{425}$ FISCHER, Roger; URY, William. Getting to Yes: Negotiating Agreement Without Giving In. 2nd. Random House Business Books, 1991. p. 52.
} 
necessário que "o negociador saiba calcular e avaliar seu BATNA, e que faça constante esforço para aprimorá-lo, pois assim terá mais alavanca em uma negociação"426.

De acordo com a teoria da sombra do direito, caso as negociações em curso falhem e o acordo não possa ser alcançado, Mnookin e Kornhauser argumentam que a possibilidade de revisão judicial dos acordos pode reduzir as possibilidades de acordos injustos. Isso, pois, se há a possibilidade de que as próprias partes levem o acordo ao judiciário, elas negociarão entre si de uma forma mais justa, havendo maior possibilidade de se chegar a um acordo que reflita as normas sociais apropriadas ao caso.

Entende-se que, quanto mais pálida ou fraca, ou até mesmo, caso não exista a sombra do direito, as partes não terão garantia de que haverá um recurso ou implementação via solução judicial de controvérsias, no caso de falha do método alternativo de solução de disputas eleito. Isso resultará, portanto, em um aumento de acordos injustos e não equânimes, o que foge ao propósito do alcance de um resultado mais favorável possível a ambas as partes ${ }^{427}$. De outro lado, se a sombra do direito é bem definida, há maior imparcialidade e se assegura um mínimo de justiça, pois se sabe que haverá a possibilidade de resolução pelo judiciário com a aplicação dos preceitos legais já estabelecidos.

Nesse contexto, destaca-se que a teoria da sombra do direito não ficou adstrita apenas ao Direito de Família, segundo sua concepção original, tendo se adequado também a outras áreas do direito, haja vista que os preceitos relativos à negociação podem ser plenamente transplantados para que se possa compreender como o direito afeta o comportamento dos agentes em outras esferas. Desse modo, esta teoria já tem sido expandida e aplicada academicamente no âmbito do Direito da Propriedade Intelectual ${ }^{428}$, do Direito Internacional Econômico e nos procedimentos da OMC, da arbitragem comercial $^{429}$, do Direito dos Contratos $^{430}$, do Direito Privado Europeu ${ }^{431}$, do Direito Internacional $^{432}$, dentre outros ramos que vêm aparecendo.

${ }^{426}$ GABBAY, Daniela; FALECK, Diego; TARTUCE, Fernanda. Meios alternativos de solução de conflitos. Rio de Janeiro: FGV, 2013. p. 28.

${ }^{427}$ ALMEIDA, Rafael Alves de; ALMEIDA, Tania; CRESPO, Mariana Hernandez. Tribunal multiportas: Investindo no capital social para maximizar o sistema de solução de conflitos no Brasil. Rio de Janeiro: FGV, 2012. p. 41.

${ }^{428}$ BUSCH, Marc L; REINHARDT, Eric. Bargaining in the shadow of the law: early settlement in GATT/WTO disputes. Fordham International Law Journal, v. 21, issue 1, p.158-172, 2000.

429 MARSELLI, Riccardo; MCANNON, Bryan C.; VANNINI, Marco. Bargaining in the shadow of arbitration. Journal of Economic Behavior \& Organization, v.117, p.356-368, 2015.

${ }^{430}$ LUMINEAU, Fabrice; MALHOTRA, Deepak. Shadow of the contract: how contract structure shapes interfirm dispute resolution. Strategic Management Journal, v. 32, p.532-555, 2011; CHAKRAVARTY, Surajeet; MACLEOD, W. Bentley. Contracting in the shadow of the law. The RAND Journal of Economics, v. 40, n. 3, p. 533-557, 2009; RUBIN, Edward L. The nonjudicial life of 
Assim sendo, tanto o investidor quanto o Estado receptor de investimentos necessitam de um mínimo de previsibilidade sobre o resultado possível caso o conflito se estenda para um litígio formal na seara dos sistemas jurisdicionais. Para isso, é preciso que se conheça o direito aplicável para que se possa negociar, haja vista que "não se pode transigir sobre o que se desconhece" 433 .

\subsection{MEIOS ALTERNATIVOS DE SOLUÇÃO DE CONTROVÉRSIAS EM INVESTIMENTOS}

Apesar de a arbitragem continuar sendo o meio preferido de solução de disputas em investimentos, devido à popularidade alcançada em função da padronização dos acordos de investimentos, não se pode olvidar que existem também outros meios eficientes para se atingir a mesma pretensão, que implicam em solução de controvérsias mais rápida, informal, amigável e menos custosa ${ }^{434}$. Nesse ínterim, verifica-se uma proliferação dos meios alternativos de solução de controvérsia também na seara dos investimentos.

Estes mecanismos consistem em procedimentos alternativos aos métodos primários, como a adjudicação pela arbitragem de investimentos e pelas cortes nacionais ${ }^{435}$. Assim sendo, conforme a UNCTAD, essas formas não tradicionais de resolução de litígios podem se dividir em negociação direta, com contato imediato e estreito entre as partes, ou negociação facilitada, através da intervenção de um terceiro, nos seus mais variados

contract: beyond the shadow of the law. Northwestern University Law Review, v. 90, n. 1, p.107-131, 1995.

${ }^{431}$ VERBEKE, Alain. Negotiating [in the shadow of a] European Private Law. Maastricht Journal of European and Comparative Law, v. 15, p.395-413, 2008.

${ }^{432}$ SCHNEIDER, Andrea K. Bargaining in the shadow of (international) law: what the normalization of adjudication in international governance regimes means for dispute resolution. New York University Journal of International Law and Politics, p.789-822, 2009.

${ }^{433}$ BRILLO, Romulo. A prevenção de controvérsias investidor-Estado e alternativas à arbitragem investidorEstado. In: RIBEIRO, Marilda Rosado de Sá. Direito Internacional dos Investimentos. Rio de Janeiro: Renovar, 2014. p. 289.

${ }^{434}$ FRANCK, Susan. Challenges facing investment disputes: reconsidering dispute resolution in international investment agreements. In: SAUVANT, Karl P. (Ed.), Appeals Mechanism in International Investment Disputes. Oxford: Oxford University Press, p.143-192, 2008, p. 158.

${ }^{435}$ Ademais, a UNCTAD pontua que a arbitragem de investimentos envolve certos obstáculos como os altos custos com representação legal, com os árbitros e experts, inclusos durante todo o tempo que durar a arbitragem, o que afeta tanto os investidores, quanto os Estados. Além disso, para as partes, lidar com a arbitragem mista envolve dificuldades de cunho político, haja vista que estas resultam, muitas vezes, de esquemas de privatização ou de contratos de concessão. Cf. UNITED NATIONS CONFERENCE ON TRADE AND DEVELOPMENT. Series on International Investment Policies for Development. InvestorState Disputes: Prevention and Alternatives to Arbitration. New York and Geneva: United Nations, 2010. p. xii e p. 4. 
graus ${ }^{436}$. Desse modo, pretende-se nesta seção pormenorizar ambas as formas de negociação, bem como suas subespécies, seus benefícios e entraves.

\subsubsection{Negociação Direta}

Dentre os meios alternativos de solução de controvérsias destaca-se a negociação direta, que consiste na negociação por meio de contato pessoal e imediato entre as partes. Desse modo, passa-se a expor as principais características da negociação direta, bem como os desdobramentos teóricos que este instituto tem alcançado na academia, com especial enfoque na Teoria da Negociação com Base em Interesses, que prioriza os objetivos e inquietações das partes, solidificando seus interesses, para então, se alcançar um acordo satisfatório.

\subsubsection{Características}

A negociação direta trata-se de método que visa à conciliação de interesses por intermédio de técnica de comunicação imediata, direta e recíproca entre as partes, com o propósito de se chegar a um acordo, através da troca de propostas e contrapropostas, e se evitar o contencioso ${ }^{437}$. Normalmente esse meio não envolve a assistência ou facilitação de terceiras partes no processo de negociação, por isso, trata-se do método em que as partes mantêm o máximo controle da disputa ${ }^{438}$. Ademais, além de consistir no meio "mais fluido, básico, e elementar, de se resolver controvérsias; é também o menos custoso"439, em função da ausência de gastos decorrentes da inclusão de terceiros.

${ }^{436}$ Segundo a UNCTAD, as abordagens alternativas podem ser consideradas perda de tempo e de recursos se não forem conduzidas de forma satisfatória, e não podem ser adequadas para todos os tipos de controvérsias sobre investimentos. Exemplo disso é que os Estados, com seus atributos únicos como partes na disputa pode enfrentar dificuldades específicas em utilizar meios alternativos. Por exemplo, sua flexibilidade em alcançar soluções mais comprometidas é limitada pelas fronteiras estabelecidas através de leis e regulamentos existentes. Cf. UNITED NATIONS CONFERENCE ON TRADE AND DEVELOPMENT. Ibid., p. xxiv.

${ }^{437}$ URY, William; BRETT, Jeanne; GOLDBERG, Stephen. Resolução de Conflitos. Lisboa: Actual Editora, 2009. p. 38. CARREAU, Dominique; JUILLARD, Patrick. Droit international économique. 5 . ed. Paris: Dalloz, 2013. p. 580.

${ }^{438}$ MERRILS, J.G. International dispute settlements. 4th. Cambridge: Cambridge University Press, 2005. p. 18.

439 GABBAY, Daniela; FALECK, Diego; TARTUCE, Fernanda. Meios alternativos de solução de conflitos. Rio de Janeiro: FGV, 2013. p. 19. 
Conforme pontua Merrils, para que uma solução negociada seja possível, as partes devem acreditar que os benefícios de um acordo excedem as perdas ${ }^{440}$, o que motivará um investidor a engajar uma negociação com o Estado receptor de investimentos, de forma a criar uma solução que abarque as necessidades e interesses exclusivos das partes. De acordo com Susan Franck, entidades privadas e Estados hospedeiros devem alocar esforços para negociação tanto quando envolver projetos mais vultosos de infraestrutura, como quando se deseja minimizar o tempo e os custos na resolução de pequenos conflitos ${ }^{441}$.

O processo negociador varia muito de acordo com os negociadores e com a matéria a ser negociada, por isso, faz-se necessário, primeiro, que as partes delineiem ou estruturem como se dará o processo (negociar como será a negociação). Estas, então, farão suas considerações iniciais, variando conforme a complexidade do caso, partindo, em seguida, para uma agenda de negociação, construída de forma conjunta entre as partes, sendo o mais importante, a identificação de pontos e interesses que deverão ser tratados na mesa de negociação, para que se crie uma zona de possíveis acordos. Isso se dá para que os dois lados tenham clareza sobre as questões realmente relevantes e que precisam ser discutidas no momento da negociação.

O próximo passo da negociação se trata da pertinência de se abordar fatos pretéritos, pontos de vista fáticos e jurídicos para, então, abrir espaço para a discussão de interesses das partes, com o intuito de se desvendar as reais necessidades, intenções e receios. Em seguida, a negociação segue para o levantamento das opções (segundo a literatura sobre resolução de conflitos, é o momento em que brainstormings são altamente recomendáveis), a ponderação de critérios objetivos a serem aplicados e os demais meios de distribuição que poderão auxiliar na busca por dissolver barreiras para que se consiga o acordo. Finalmente, as partes se encarregarão de avaliar as alternativas resultantes do sopesamento de todos esses elementos e, em caso de interesse das partes, firmam acordo.

Ressalta-se que, alguns tratados de investimentos preveem a obrigação de se negociar para se resolver o litígio, antes que se acione o mecanismo arbitral ${ }^{442}$. O TBI EUA- Uruguai, por exemplo, em seu art. 23, intitulado Consulta e Negociação está redigido da seguinte maneira: "No caso de uma disputa de investimento, o demandante e o demandado devem inicialmente procurar resolver a disputa por meio de consulta e

\footnotetext{
${ }^{440}$ MERRILS, J.G. op. cit., p. 12.

${ }^{441}$ FRANCK, Susan. Challenges facing investment disputes: reconsidering dispute resolution in international investment agreements In: SAUVANT, Karl P. (Ed.). Appeals Mechanism in International Investment Disputes. Oxford: Oxford University Press, p.143-192, 2008. p.167.

442 CARREAU, Dominique; JUILLARD, Patrick. Droit international économique. 5ed. Paris: Dalloz, 2013. p. 581 .
} 
negociação, que pode incluir a utilização de procedimentos não obrigatórios, procedimentos de terceiros" ${ }^{\prime 43}$. (tradução nossa)

Entretanto, nem todos os APPRIs dispõem sobre isso de forma clara e direta. O tratado bilateral de investimento francês, apesar de não prever a palavra negociação, ressalta sobre a importância de se atingir uma solução amigável entre as partes. Isso pode ser examinado segundo o art. $8^{\circ}$ do TBI França-Argélia: “Qualquer litígio relacionado a investimentos entre uma das partes contratantes e um investidor da outra parte contratante deve, sempre que possível, ser resolvido de forma amigável entre as duas partes interessadas" ${ }^{444}$. (tradução nossa)

O mesmo TBI ainda prevê que, se as partes não conseguirem alcançar acordo amigável no período de 6 meses contados do início do litígio, poderá submetê-lo à arbitragem. Assim sendo, conclui-se que o Direito dos Investimentos também tem delineado bases para a solução negociada de controvérsias, prevendo de forma direta a negociação e conciliação ou de forma indireta esses institutos através da prerrogativa de se aplicar uma forma amigável para resolver as disputas.

\subsubsection{Fundamentos da Teoria da Negociação com Base em Interesses}

Como já exposto, a teoria da sombra do direito, que tem raízes americanas, além de ter sido criada sob inspiração da legislação dos EUA, teve como berço duas das mais renomadas escolas de Direito do país. Não por acaso, um de seus criadores, Robert Mnookin, é proveniente da Harvard Law School, local onde originou-se a teoria da negociação com base em interesses, e é diretor do Programa de Negociação de Harvard, o

\footnotetext{
${ }^{443}$ No Original: "In the event of an investment dispute, the claimant and the respondent should initially seek to resolve the dispute through consultation and negotiation, which may include the use of nonbinding, third-party procedures". Treaty between the United States of America and the Oriental Republic of Uruguay concerning the encouragement and reciprocal protection of investment. TREATY BETWEEN THE UNITED STATES OF AMERICA AND THE ORIENTAL REPUBLIC OF URUGUAY CONCERNING THE ENCOURAGEMENT AND RECIPROCAL PROTECTION OF INVESTMENT. Disponível em: $<$ https://ustr.gov/sites/default/files/uploads/agreements/bit/asset_upload_file748_9005.pdf $>$. Acesso em: 3 out. 2015.

${ }^{444}$ No original: "Tout différend relatif aux investissements entre l'une des parties contractante et um investisseur de l'autre partie contractante est, autant que possible, réglé à l'amiable entre les deux parties concernées". Accord entre le gouvernement de la Republique Française et le Gouvernement de la Republique Algerienne Democratique et Populaire sur l'encouragement et la protection reciproques des investissements. ACCORD entre le gouvernement de la Republique Français et le Gouvernement de la Republique Algerienne democratique et populaire sur l'encouragement et la protection reciproques des investissements.. Disponível em: <http://investmentpolicyhub.unctad.org/Download/TreatyFile/46>. Acesso em: 3 out. 2015.
} 
que dá a entender que, de certa forma, esta teoria compartilha de preceitos parecidos com os da sombra do direito.

Nesse sentido, ao se falar de negociação julga-se necessário abordar a teoria da negociação com base em interesses para que se possa concatenar como a negociação direta, em especial aquela baseada em interesses, é vista como meio eficiente no plano do Direito dos Investimentos para se alcançar uma solução alternativa de conflitos e como tal percepção teórica pode ser útil para a justificação de um espaço que enseje a negociação.

Segundo Ury, Brett e Goldberg, todo conflito e toda negociação envolvem três enfoques diferentes para a sua resolução: poder, regras e interesses. Esses três planos sempre estarão presentes, contudo, em se tratando de um problema mútuo, em uma negociação, cabe às partes escolherem qual aspecto vai ser focalizado. O primeiro deles é a relação de poder em que estão submetidas as partes, haja vista que existindo uma medida de "quanto uma parte está submetida à capacidade da outra lhe impor a sua vontade" seja, do grau de dependência de uma parte em relação a outra na imposição ou ameaça de custos, quanto mais e melhores as alternativas disponíveis na negociação com outra parte, menor sua dependência ${ }^{446}$. Contudo, em função da ameaça que paira na aplicação desse foco específico de negociação, pode haver destruição de valor para as partes.

O segundo corresponde em aceitar um padrão reconhecido como legítimo e justo e, através do direito - por exemplo, da lei ou de um contrato -, determinar quem tem razão. Trata-se de viés de difícil determinação sem o auxílio de um terceiro, pois os direitos raramente são claros e bem definidos, pautando-se por diferentes normativas, que muitas vezes se revelam contraditórias, além de o ser humano, por natureza, ser reticente a se deixar convencer ou a admitir que está errado ${ }^{447}$. No plano do Direito dos Investimentos, a solução de controvérsias respaldada no direito é a proporcionada pelas cortes nacionais e pela arbitragem mista, que irão analisar se o Estado receptor violou ou não o previsto no TBI ou no contrato estabelecido. O terceiro refere-se aos interesses, que são as necessidades, objetivos e preocupações das partes, e compõem a posição defendida por elas em uma mesa de negociação, em que cada lado defenderá sua posição e, caso esta não seja aceita, haverá a ciência de que consequências mais graves ocorrerão a posteriori. Os benefícios deste último enfoque residem no fato de que para cada interesse, existem

445 GABBAY, Daniela; FALECK, Diego; TARTUCE, Fernanda. Meios alternativos de solução de conflitos. Rio de Janeiro: FGV, 2013. p. 22.

${ }^{446}$ URY, William; BRETT, Jeanne; GOLDBERG, Stephen. Resolução de Conflitos. Lisboa: Actual Editora, 2009. p. 40.

${ }^{447}$ URY, William; BRETT, Jeanne; GOLDBERG, Stephen. Resolução de Conflitos. Lisboa: Actual Editora, 2009. p. $40-41$. 
diversas posições possíveis, o que auxilia no incremento da satisfação das partes com os resultados $^{448}$, que identificarão qual abordagem contêm elementos mais relevantes para cada lado, até se chegar a um acordo satisfatório para ambas as partes ${ }^{449}$. Conforme aduzem Ury, Brett e Goldberg (2009, p. 40):

\begin{abstract}
A conciliação de interesses tende a produzir um nível mais elevado de satisfação com os resultados do que a determinação dos direitos ou do poder. Se as partes ficarem mais satisfeitas, o seu relacionamento melhora e as probabilidades de recorrência do conflito diminuem. De um modo geral, estabelecer quem tem razão ou quem é mais poderoso, enfatizando o conceito de vitória ou derrota, apenas contribui para tornar a relação mais tensa a antagónica. Por outro lado, a parte vencida raramente desiste e recorre a um tribunal superior ou arquitecta uma vingança. É certo que a conciliação dos interesses pode, por vezes, ser um processo moroso, nomeadamente quando o número de intervenientes no conflito é elevado. No entanto, estes custos costumam diminuir quando comparados com os custos dos confrontos diretos ou de poder, como acontece nos julgamentos $(\ldots)^{450}$.
\end{abstract}

O processo de negociação baseados em interesse pode abranger tanto negociações diretas, quanto outros processos baseados na intervenção de terceiros como facilitadores, como a conciliação, mediação ou o ombudsman (que neste trabalho, como se verá, está classificado como meio preventivo de controvérsias). Nesse diapasão, apesar de a reconciliação de interesses envolver tempo e esforços, eles acabam se tornando pequenos se comparados aos custos de transação dos conflitos e negociações baseados no poder ou na força e no direito, como litígios internacionais vultosos, ofensivas diplomáticas ou, até mesmo, conflitos de cunho bélico ${ }^{451}$.

Ademais, a opção na abordagem da negociação baseada em interesses não faz com que os outros enfoques desapareçam. Se não houver lei, contrato ou diretriz clara e hábil que vincule a parte a fazer ou deixar de fazer algo, "ou mesmo uma relação de mercado, imagem ou poder relacionada, pode ser muito difícil trazer uma parte para uma

448 GABBAY, Daniela; FALECK, Diego; TARTUCE, Fernanda. Meios alternativos de solução de conflitos. Rio de Janeiro: FGV, 2013. p. 23.

${ }^{449}$ Isso, pois, caso uma das partes ainda se mantenha insatisfeita, é mais provável que esta descumpra o acordo ou, então, se os termos do mesmo forem excessivos, será difícil para que a parte o cumpra, o que também acarretará em descumprimento. O fato é que, o acordo não precisa ser totalmente equilibrado, com ganhos repartidos no meio, contudo, deve satisfazer minimamente o interesse da outra parte. Cf. GABBAY, Daniela; FALECK, Diego; TARTUCE, Fernanda. Ibid. p. 28.

${ }^{450}$ URY, William; BRETT, Jeanne; GOLDBERG, Stephen. Resolução de Conflitos. Lisboa: Actual Editora, 2009. p. 38. CARREAU, Dominique; JUILLARD, Patrick. Droit international économique. 5. ed. Paris: Dalloz, 2013, p. 47.

${ }^{451}$ SMITH, Stephanie; MARTINEZ, Janet. An analytic framework for disputes systems design. Harvard Negociation Law Review, v. 14, p.123-169, 2009, p. 126; BRILLO, Romulo. A prevenção de controvérsias investidor-Estado e alternativas à arbitragem investidor-Estado In: RIBEIRO, Marilda Rosado de Sá. Direito Internacional dos Investimentos. Rio de Janeiro: Renovar, p.271-299, 2014. p. 278. 
mesa de negociação" ${ }^{\text {452 }}$. No entanto, mesmo com o direito, se não houver uma ameaça presumível de que uma parte adotará as medidas legais, judiciais ou arbitrais cabíveis contra a outra, ou seja, a sombra do direito, talvez a última parte não vislumbre motivos para se empenhar para uma negociação e direcionar-se para o enfoque baseado em interesses, para alcançar um resultado mais adequado e efetivo ${ }^{453}$.

\subsubsection{Negociação Facilitada}

Quando as partes constantes em um litígio são incapazes de resolvê-lo diretamente por negociação, a intervenção de um terceiro torna-se meio possível para tentar resolver o impasse e alcançar uma solução aceitável que seja benéfica tanto para uma parte, quanto para outra. Essa intervenção, classificada pela doutrina como negociação facilitada, pode se dar de diferentes maneiras, de acordo com o propósito e o momento da intervenção, porquanto em cada uma delas, o papel que o terceiro desempenhará também será distinto. Este pode simplesmente encorajar os Estados e entidades privadas a retomarem as negociações ou apenas proporcionar-lhes um canal adicional de comunicação.

Nessas iniciativas, as partes detêm maior controle do processo se comparado aos meios judiciais de solução de controvérsias, e preservam seu direito de aprovar ou refutar o acordo proposto ou, ainda, se retirar inteiramente do processo de solução alternativa de controvérsias $^{454}$. Salienta-se que esses mecanismos têm sido incorporados nos APPRIs de formas variadas e há limites para seu uso, bem como também estão previstos em regulamentos institucionais. Desse modo, passa-se a expor os métodos facilitados mais frequentes e relevantes para a análise desejada: mediação, conciliação e fact-finding.

\subsubsection{Mediação}

Quando as partes não conseguem resolver uma disputa internacional por meio da negociação, torna-se viável a ação de um terceiro neutro, para que atue informalmente de forma a auxiliá-las a superarem o impasse e a alcançarem uma solução aceitável. A

452 GABBAY, Daniela; FALECK, Diego; TARTUCE, Fernanda. Meios alternativos de solução de conflitos. Rio de Janeiro: FGV, 2013. p. 24.

${ }^{453}$ GABBAY, Daniela; FALECK, Diego; TARTUCE, Fernanda. Ibid. p. 24.

${ }^{454}$ UNITED NATIONS CONFERENCE ON TRADE AND DEVELOPMENT. Series on International Investment Policies for Development. Investor-State Disputes: Prevention and Alternatives to Arbitration. New York and Geneva: United Nations, 2010. p. 26. 
mediação consiste em um procedimento em que um terceiro (mediador), consentido pelas partes, atua na aproximação destas para que cheguem a um acordo. Isso pode ser realizado com o mediador facilitando o canal de comunicação entre as partes, focando na identificação de interesses e no aclaramento de pontos de vista específicos e criando uma atmosfera que conduza à negociação. Por fim, este oferecerá propostas informalmente, com base nas informações prestadas pelas partes ${ }^{455}$.

Esse meio de solução de controvérsias é estabelecido de forma consensual e envolve a cooperação voluntária dos participantes, portanto, faz-se necessário que haja disposição e boa-fé tanto dos investidores, quanto dos Estados, para que possam dialogar na busca de soluções conjuntas. No Direito dos Investimentos, a mediação é um meio utilizado antes da adjudicação e o papel do mediador consiste, basicamente, em estabelecer um diálogo entre entidades privadas e Estados nacionais, para efetivamente propor e organizar um acordo manejável para a disputa. Apesar de ser requisitado pelas partes para operar ativamente, o mediador assumirá o procedimento apenas até certo grau e, assim, se retirará a partir da tomada de controle das partes. Desse modo, na mediação não há a imposição de uma decisão final por terceiros, nem vinculação em aceitar a sugestão do mediador ${ }^{456}$. A solução da disputa através de acordo, portanto, será o resultado de sua intervenção, certificando a real vontade dos interessados ${ }^{457}$.

O CIRDI não provê um mecanismo de mediação, apesar de já ter demonstrado interesse em implementar uma via para facilitá-la entre investidores e Estados, permitindo que as partes resolvam seus conflitos de maneira mais informal, voluntária e confidencial. Essa sistemática facilitaria a comunicação entre as partes e diminuiria o risco que advém de uma adjudicação ao passo que preservaria custos e tempo. Entretanto, apesar das sugestões para a instauração desse mecanismo, o futuro dele ainda é incerto ${ }^{458}$.

${ }^{455}$ MERRILS, J.G. International dispute settlements. 4ed. Cambridge: Cambridge University Press, 2005. p. 28 e 32. FRANCK, Susan. Challenges facing investment disputes: reconsidering dispute resolution in international investment agreements In: SAUVANT, Karl P. (Ed.). Appeals Mechanism in International Investment Disputes. Oxford: Oxford University Press, 2008. p. 172; OPPETIT, Bruno. Teoría del arbitraje. Bogotá: Legis, p. 143-192, 2006. p.74.

${ }^{456}$ MERRILS, J.G. International dispute settlements. 4ed. Cambridge: Cambridge University Press, 2005. p. 29.

457 UNITED NATIONS CONFERENCE ON TRADE AND DEVELOPMENT. Series on International Investment Policies for Development. Investor-State Disputes: Prevention and Alternatives to Arbitration. New York and Geneva: United Nations, 2010. p. 25.

${ }^{458}$ FRANCK, Susan. Challenges facing investment disputes: reconsidering dispute resolution in international investment agreements In: SAUVANT, Karl P. (Ed.). Appeals Mechanism in International Investment Disputes., Oxford: Oxford University Press, p.143-192, 2008. p. 174. 
Já a Câmara de Comércio Internacional possui Regulamento de Mediação, pelo qual sua mais nova edição corresponde a de $2014^{459}$, o que revela sua proeminência na solução de disputas internacionais. Essas regras se focam em termos contratuais de iniciação da mediação e na escolha do mediador, dando-lhe ampla liberdade para conduzir o processo de acordo com a vontade das partes.

Por fim, nota-se que a mediação comercial internacional pode surgir por uma variedade de formas. Na maioria das vezes, as partes têm concordado na disposição da cláusula med-arb, em que se prevê, preliminarmente, que as disputas provenientes do contrato serão mediadas e, caso esse mecanismo falhe, será dado seguimento à arbitragem.

\subsubsection{Conciliação}

A conciliação baseia-se em um método formal e um processo estruturado de negociação facilitada. Envolve a assistência de um terceiro (conciliador), que encorajará as partes a buscarem a resolução da controvérsia de forma amigável. Ressalta-se que o conciliador pode ou não ser neutro, logo, seu grau de engajamento pode variar, assim como sua autoridade ${ }^{460}$. Apesar de existirem diferenças de caso para caso, os conciliadores usualmente tentam delinear um processo de interação mais produtivo entre as partes e tentam melhorar a comunicação entre elas, enquanto levantam questões substantivas.

A conciliação normalmente segue regras e procedimentos formais e encerra-se com um acordo escrito ou, no mínimo, recomendações por escrito, que demonstram a solução real proposta, porém, esta não é vinculante para as partes. Assim, esse instituto caracteriza-se como formal, estruturado e orientado para resultados. Destaca-se que o conciliador tenta manter o controle substancial durante todo o processo de conciliação e, em razão disso, possui papel mais ativo que o do mediador, o qual é mais dependente da atitude das partes ${ }^{461}$.

Desse modo, a principal distinção entre a mediação e a conciliação é o grau de formalidade do procedimento. $\mathrm{Na}$ mediação, há predominância da informalidade e a atuação do mediador depende das informações cedidas pelas partes, logo, todo o trabalho

\footnotetext{
${ }^{459}$ Para mais informações: CORTE INTERNACIONAL DE ARBITRAGEM CENTRO INTERNACIONAL DE ADR. Regulamento de Arbitragem Regulamento de Mediação. Disponível em: $<$ http://www.iccwbo.org/Data/Documents/Buisness-Services/Dispute-ResolutionServices/Mediation/Rules/2012-Arbitration-Rules-and-2014-Mediation-Rules-PORTUGUESE-version/>. ${ }^{460}$ SMITH, Stephanie; MARTINEZ, Janet. Na analytic framework for disputes systems design. Harvard Negociation Law Review, v.14, .123-169, 2009. p. 166.

${ }^{461}$ OPPETIT, Bruno. Teoría del arbitraje. Bogotá: Legis, 2006. p. 74. COLLIER, John, LOWE, Vaughan. The settlement of disputes in international law. Oxford: Oxford University Press, 1999. p. 29.
} 
de negociação é, de fato, realizado pelas partes. Já na conciliação, o procedimento é formal, podendo o conciliador conduzir investigações e efetuar recomendações ou propostas. Não obstante, nenhum dos dois mecanismos imporá um resultado às partes ${ }^{462}$.

O CIRDI possui Regras de Conciliação para formalmente auxiliar as partes no alcance de uma resolução amigável para o conflito. O mecanismo de conciliação funciona seja através de um único conciliador, seja por meio de um corpo de conciliadores. Há uma lista de conciliadores, caso se opte por utilizá-la, e o acordo não vinculante resultante visa não apenas ao melhoramento da relação entre as partes, mas também atingir uma solução concreta. Por esse motivo, a conciliação é identificada por vezes como arbitragem não vinculante. Segundo o Relatório dos Diretores Executivos do CIRDI, a principal diferença entre os dois institutos é que a conciliação procura levar as partes a um acordo, enquanto a arbitragem visa a uma determinação vinculante da disputa pelo tribunal arbitra ${ }^{463}$. Apesar da existência desse mecanismo, sua utilização ainda é bem baixa, sendo que até os dias de hoje, existem apenas 7 casos resolvidos pela Conciliação através da Convenção CIRDI e 2 casos de conciliação do Mecanismo Complementar do CIRDI, totalizando 9 casos ao todo. Alguns motivos para tanto são que, apesar de ser um procedimento satisfatório, seu uso é limitado em razão do desconhecimento dos potenciais utilizadores e a falta de interesses das $\operatorname{partes}^{464}$.

A UNCITRAL também possui regras de conciliação, intituladas UNCITRAL Model Law on International Commercial Conciliation, que atuam de forma conjunta com a UNCITRAL Conciliation Rules of 1980. Este procedimento é mais discricionário e flexível que o do CIRDI, porém, continua sendo parecido com o de qualquer conciliação, em que o conciliador analisará os pontos de vistas das partes em disputa e, ao final, realizará um relatório sugerindo acordo. As partes, por sua vez, poderão aceitar ou rejeitá-lo, ou, então, poderão utilizar o acordo proposto pelo conciliador como base para futuras negociações. Além disso, o processo de conciliação é voluntário e confidencial, podendo a parte retirarse a qualquer tempo. Ademais, faz-se necessário ressaltar que tanto a mediação, quanto a conciliação não são adequadas para toda e qualquer disputa sobre investimentos. Nas palavras de Daniel Tavela Luís (2013, p. 125):

462 LUís, Daniel Tavela. Proteção do Investimento Estrangeiro: O Sistema do Centro Internacional para Resolução de Disputas Relativas ao Investimento (CIRDI) e suas Alternativas. 2013. 189 f. Dissertação (Mestrado em Direito) - - Faculdade de Direito da Universidade de São Paulo, São Paulo, 2013.. f. 125.

${ }^{463}$ UNITED NATIONS CONFERENCE ON TRADE AND DEVELOPMENT. Series on International Investment Policies for Development. Investor-State Disputes: Prevention and Alternatives to Arbitration. New York and Geneva: United Nations, 2010. p. 55.

${ }^{464}$ Ibid. p. 62. 
Não se pode ignorar a natureza pública de uma das partes do processo, a qual pode sofrer limitações para fazer um acordo e a natureza pública do direito aplicável, haja vista que muitas vezes são feitas acusações de violação a obrigações assumidas internacionalmente. Parte das questões mais difíceis discutidas no âmbito da arbitragem de investimentos diz respeito a requisitos jurisdicionais e a políticas públicas, assuntos que fogem à capacidade negocial do Estado, especialmente. Ademais, em geral, o ato estatal questionado termina a relação Estatal com o investidor, de forma que não há relação futura a se proteger $^{465}$.

Quanto às políticas públicas, ressalta-se que o Estado receptor de investimentos é legítimo para reafirmar sua prerrogativa de regular o domínio econômico, do meio ambiente, do consumidor, dentre outros, com políticas públicas que considera chave e, diante da sensibilidade de determinados temas, o governo pode entender por bem não negociar. Desse modo, diante da negação em se transigir, o caso pode ser levado ao meio jurisdicional de solução de controvérsias (a arbitragem mista).

\subsubsection{Fact-Finding}

O fact-finding trata-se de procedimento privado, voluntário, confidencial e não vinculativo em que as partes submetem informações factuais, como informações técnicas, científicas, contábeis ou econômicas a um expert para que haja uma avaliação neutra dos fatos contestados ${ }^{466}$. Presente como uma das modalidades de inquérito, o grande propósito desse procedimento é conseguir efetuar análises imparciais sobre os fatos, com a finalidade de prevenir futuras disputas. Segundo pontua Susan Franck, o fact-finding trata-se de procedimento que tem potencial de circunscrever ou limitar a matéria em disputa e criar um denominador comum entre as partes ${ }^{467}$.

O Mecanismo Complementar do CIRDI implementou o Procedimento de Constatação de Fatos (fact-finding proceedings) em 1978, estabelecendo um comitê independente encarregado de examinar os fatos presentes na disputa. Como originalmente

${ }^{465}$ LUÍS, Daniel Tavela. Proteção do Investimento Estrangeiro: O Sistema do Centro Internacional para Resolução de Disputas Relativas ao Investimento (CIRDI) e suas Alternativas. 2013. 189f. Dissertação (Mestrado em Direito). Faculdade de Direito da Universidade de São Paulo, São Paulo, 2013. p. 125.

${ }^{466}$ Nessa seara, em razão de a essência ser a mesma, pode-se realizar comparação com o conceito de factfinding presente na Resolução e Declaração sobre Fact-Finding da ONU: "any activity designed to obtain detailed knowledge of the relevant facts of any dispute or situation which the competente United Nations organs need in order to exercise effectively their functions in relation to the maintenance of international peace and security". Cf. COLLIER, John; LOWE, Vaughan. The settlement of disputes in international law: institutions and procedures. Oxford: Oxford University Press, 1999. p. 27.

${ }^{467}$ FRANCK, Susan. Challenges facing investment disputes: reconsidering dispute resolution in international investment agreements In: SAUVANT, Karl P. (Ed.). Appeals Mechanism in International Investment Disputes, Oxford: Oxford University Press, p.143-192, 2008. p.180. 
concebido, o Mecanismo Complementar e o Procedimento de Constatação de Fatos foram propostos a serem "um procedimento para prevenir, em vez de resolver disputas legais, como resultado de uma percepção da necessidade de procedimentos de fact-finding na fase de anterior à disputa" ${ }^{468}$. Será realizada análise imparcial dos fatos, por meio de procedimentos orais, submissões escritas, evidências e inquirição das testemunhas. Conforme já explicitado ao discorrer sobre o Mecanismo Complementar, este instituto detém grande importância para a conciliação ou no caso de uma futura arbitragem, visto que pode auxiliar para o alcance de uma solução negociada, coordenando as posições das partes e uniformizando a matéria de fato ${ }^{469}$. Diferentemente da conciliação e da arbitragem, o Procedimento de Constatação de Fatos não exige que ao menos uma das partes seja membro do $\mathrm{CIRDI}^{470}$, sendo o mecanismo aberto para qualquer investidor ou governo que deseje iniciar o procedimento.

O fact-finding, portanto, colabora para prevenir entendimentos diversos sobre os fatos, que podem escalar para uma futura controvérsia jurídica, realizando uma avaliação preliminar da reclamação. Segundo o art. 16 do Regulamento do Procedimento de Constatação de Fatos, o fact-finding envolve procedimentos orais, submissões escritas, provas materiais e testemunhas e encerra-se com um relatório limitado à matéria de fato, $\mathrm{o}$ qual não é de caráter vinculante e não oferece recomendações às partes, logo, a controvérsia ainda não será resolvida, porém, caberá às partes sopesarem através da análise realizada se valerá a pena seguir com a demanda e qual método será o mais adequado diante do relatório fático exposto.

Contudo, destaca-se que as regras sobre o fact-finding ainda são pouco utilizadas. Até os dias de hoje, esse mecanismo ainda é raro na redação dos APPRIs, não havendo, no âmbito do CIRDI, nenhum caso até o momento. O motivo é semelhante ao da baixa utilização do Mecanismo de Conciliação do CIRDI, qual seja a falta de conhecimento da existência do procedimento, somado também ao fato de não ser vinculativo, o que pode

${ }^{468}$ ICSID Additional Facility for the administration of conciliation, arbitration and fact-finding, 2003, p. vi apud FRANCK, Susan. Challenges facing investment disputes: reconsidering dispute resolution in international investment agreements In: SAUVANT, Karl P. (Ed.) Appeals Mechanism in International Investment Disputes. Oxford: Oxford University Press, p.143-192, 2008. p. 181.

${ }^{469}$ COSTA, José Augusto Fontoura. Direito Internacional do Investimento Estrangeiro. Curitiba: Juruá, 2010. p. 207; COSTA, José Augusto F.; CARREGARO, Ana Carolina C.; ANDRADE, Thiago P. Mecanismo complementar do ICSID: uma alternativa para investidores brasileiros? Revista Direito GV. v. 3, n. 2, p. 59-75, jul/dez. 2007. p. 67.

${ }^{470}$ FRANCK, Susan. Challenges facing investment disputes: reconsidering dispute resolution in international investment agreements In: SAUVANT, Karl P. (Ed.). Appeals Mechanism in International Investment Disputes, Oxford: Oxford University Press, p.143-192, 2008. p. 180. 
torná-lo impróprio para alguns $\operatorname{casos}^{471}$. O fato é que esse mecanismo se torna benéfico visto que, além de sua eficiência, seus custos institucionais de manutenção são mínimos, por isso, faz-se necessário que ele seja mais divulgado para que se torne mais aceitável às partes interessadas, o que virá a aumentar sua aplicação ${ }^{472}$.

\subsection{MEIOS PREVENTIVOS DE SOLUÇÃO DE CONTROVÉRSIAS EM INVESTIMENTOS}

A prevenção de litígios tem como objetivo precípuo minimizar potenciais áreas de conflitos por meio de um planejamento institucional. No Direito dos Investimentos não é diferente, havendo políticas de prevenção de disputas com o envolvimento de agências governamentais domésticas e, também, através da cooperação internacional entre Estados. Desse modo, pretende-se nesta seção discorrer sobre as características e implicações dos meios preventivos de solução de controvérsias em investimentos e, em seguida, analisar alguns exemplos de mecanismos preventivos evidenciados pela doutrina.

\subsubsection{Características}

As políticas de prevenção de controvérsias consistem em práticas que tentam prevenir os conflitos entre investidores e Estados antes mesmo de surgirem, ou seja, antecipam-se para evitar uma escalada de um desentendimento preliminar a uma disputa formal, estabelecendo mecanismos de alerta interinstitucional no âmbito dos Estados ou encorajando o compartilhamento de informações entre entidades governamentais responsáveis ${ }^{473}$.

Segundo a UNCTAD, esse conceito ainda é relativamente novo, porém, os meios de prevenção de disputas já são reconhecidos como uma abordagem contemporânea para se lidar com controvérsias sobre investimentos. Esses mecanismos preventivos, formais ou informais, podem se manifestar de diversas maneiras para a administração de um

\footnotetext{
${ }^{471}$ FRANCK, Susan. Challenges facing investment disputes: reconsidering dispute resolution in international investment agreements In: SAUVANT, Karl P. (Ed.). Appeals Mechanism in International Investment Disputes, Oxford: Oxford University Press, p.143-192, 2008, p. 181.

${ }^{472}$ No contexto do Direito Internacional Público, os organismos que realizam o fact-finding, como o Inquérito (Inquiry) existente no âmbito da Corte Permanente de Arbitragem, têm sido úteis para a efetivação de investigações imparciais dos fatos do litígio.

${ }^{473}$ UNITED NATIONS CONFERENCE ON TRADE AND DEVELOPMENT. Investor-State Disputes: Prevention and Alternatives to Arbitration. New York and Geneva: United Nation Publications, 2010. p. xxiv.
} 
conflito $^{474}$. No entanto, um ponto comum entre todos eles é que estabelecem um mecanismo efetivo de alerta institucional em um estágio inicial. Assim sendo, a partilha de informações entre as agências governamentais sobre questões relativas ao investimento, se realizada de uma forma bem estruturada e organizada pode garantir que os governos sejam advertidos já em fase preliminar à emergência de um conflito, permitindo que uma resposta chegue tempestivamente antes de iniciado o litígio formal. Além disso, o compartilhamento de informações em geral aumentará a atenção dos órgãos governamentais em diferentes níveis de governo (como por exemplo, em nível regional ou municipal) a questões relevantes do Direito Internacional de Investimento ${ }^{475}$.

Os governos, por sua vez, podem dispender maior atenção a setores sensíveis específicos em que haja maior probabilidade do surgimento de disputas e monitorar as atividades de investidores estrangeiros neste setor, o que dirimiria possíveis problemas em fase precoce. Ademais, esse meio possibilita que os governos demonstrem sua insatisfação com determinada política pública ou medida editada pelo Estado receptor de investimentos ou que ofereçam ao investidor estrangeiro o direito de pedir uma revisão administrativa de medidas consideradas insatisfatórias.

Assim sendo, essa abordagem permite dar ao governo informações sobre o problema que emerge, além de tempo e flexibilidade suficientes para analisar os problemas dos investidores, unilateralmente ou em coordenação com entidades privadas. Dessa forma, os mecanismos de prevenção podem ser considerados como uma abordagem promissora para resolver o problema do aumento de litígios formais. Enquanto procedimentos judiciais de solução de controvérsias têm de lidar com uma disputa já existente que necessita ser acordada, a prospecção de não se ter nenhuma disputa deve ser uma opção preferível na visão dos governos.

Os mecanismos interinstitucionais de prevenção de controvérsias implicam na criação de uma agência principal, responsável por lidar com disputas de investimento, em uma única instância, e que possuirá o direito de obter informações de agências governamentais e de autoridades para resolver os desentendimentos surgidos. Nesse contexto, funcionários públicos específicos e designados podem ser habilitados com prerrogativas de operar de forma oficial na análise das negociações com os investidores em busca de uma solução amigável.

\footnotetext{
${ }^{474}$ BRILLO, Romulo. A prevenção de controvérsias investidor-Estado e alternativas à arbitragem investidorEstado. In: RIBEIRO, Marilda Rosado de Sá. Direito Internacional dos Investimentos. Rio de Janeiro: Renovar, p. 271-299, 2014.p. 287.

${ }^{475}$ UNITED NATIONS CONFERENCE ON TRADE AND DEVELOPMENT. op.cit. p. 29.
} 
Outrossim, as políticas de prevenção de controvérsias podem ser instituídas através de dois níveis distintos. O primeiro corresponde ao nível interno, em que serão avaliadas medidas administrativas e políticas que possam melhorar o seu sistema institucional endógeno, introduzindo iniciativas que facilitem a comunicação e coordenação com as autoridades governamentais relevantes para a resolução de $\operatorname{conflitos}^{476}$. Portanto, aqui se refere à coordenação intra estatal para dirimir entraves entre investidores e Estado ${ }^{477}$. O segundo diz respeito ao plano externo, centrada nos Estados por intermédio da cooperação internacional. Esta pode ser exteriorizada através de previsões em tratados ou contratos de investimentos para que as partes fomentem a cooperação na administração de conflitos surgidos. A administração deve ser realizada antes do envio da notificação de instauração da arbitragem, pois, o período denominado cooling-off, que corresponde àquele período de 3 a 6 meses, da notificação até o início da arbitragem, já demonstram a realidade da existência de uma controvérsia. Outra forma de cooperação consiste na previsão em APPRIs de procedimentos de consultas bilaterais entre Estados, que farão análise prévia sobre a espécie de conflito, filtrando a sua remessa à arbitragem ${ }^{478}$ ou elucidarão o conteúdo dos dispositivos aplicáveis dos APPRIs. Por fim, essa prevenção cooperativa também pode ser realizada por intermédio da troca de protocolos de comunicação e consultas intergovernamentais.

Destaca-se que muitos países já começaram a implementar essas medidas de políticas preventivas, que já têm se convertido em boas práticas. Isso não significa que o Estado estará imune à ocorrência de qualquer disputa, contudo, serão tomadas iniciativas concretas rumo a evitar que o conflito evolua e se cristalize em disputas formais sob a égide de um tratado de investimentos. Em razão da pertinência com o presente trabalho, dentre as várias políticas preventivas existentes, serão ressaltadas a instituição do

${ }^{476}$ UNITED NATIONS CONFERENCE ON TRADE AND DEVELOPMENT. Investor-State Disputes: Prevention and Alternatives to Arbitration. New York and Geneva: United Nation Publications, 2010. p.30; BRILLO, Romulo. A prevenção de controvérsias investidor-Estado e alternativas à arbitragem investidor-Estado In RIBEIRO, Marilda Rosado de Sá. Direito Internacional dos Investimentos. Rio de Janeiro: Renovar, p.271-299, 2014. p. 294.

${ }^{477}$ Conforme pontua Romulo Brillo, importante lembrar que "mais da metade das arbitragens diz respeito não aos governos centrais, que negociaram os AIIs e os contratos de investimento, mas aos entes subnacionais e aos órgãos governamentais responsáveis pela regulação de setores específicos da economia". BRILLO, Romulo. Ibid.. p. 294.

${ }^{478}$ Ressalta-se que alguns acordos regionais com capítulos de investimentos preveem essa cooperação, como o NAFTA e o CAFTA, que instituíram comissões compostas por autoridades dos membros legitimados a emitir interpretações. Ainda, existem também TBIs preocupados com a implementação dessa "filtragem conjunta", nas palavras de Romulo Brillo, como é o caso dos TBIs de Canadá com Romênia e Letônia. Cf. BRILLO, Romulo. A prevenção de controvérsias investidor-Estado e alternativas à arbitragem investidor-Estado In: RIBEIRO, Marilda Rosado de Sá. Direito Internacional dos Investimentos. Rio de Janeiro: Renovar, p.271-299, 2014. p. 294. 
ombudsman e outras iniciativas de cooperação para a prevenção de disputas pontuais, como as comissões interministeriais de alto nível e a prevenção de controvérsias setor a setor, em razão de se mostrarem contributivas e evidenciarem a cooperação com o setor privado.

\subsubsection{Ombudsman}

O conceito original de ombudsman foi suscitado inicialmente na Escandinávia - o que explica a origem sueca do termo - para definir uma pessoa designada pelo Estado para investigar as queixas e alegações de abuso de poder ou de má administração - situações em que o desempenho de um departamento do governo encontrava-se abaixo de padrões aceitáveis da administração - por funcionários ou instituições públicas ${ }^{479}$. Com o passar dos anos, esse instituto foi se expandindo para outros países, como o Reino Unido, em que o primeiro ombudsman designado estava sob a égide do Parliamentary Commissioner Act de 1967, operando sob o título do Comissário Parlamentar para a Administração ${ }^{480}$.

Contudo, hoje em dia, houve uma proliferação da utilização do ombudsman também para outras esferas. No Reino Unido, por exemplo, existe a presença de ombudsman na administração pública e em diversas subáreas, como ombudsman que cuida de questões relativas à saúde, no âmbito prisional, para a administração central e no plano de governos locais, bem como na operação de serviços jurídicos, na área bancária e de seguros. Em 2013, o governo anunciou sua intenção de introduzir um único ombudsman de governo local para a Inglaterra. Por fim, salienta-se que, nos países escandinavos, Dinamarca, Finlândia ${ }^{481}$, Noruega e Suécia ${ }^{482}$, o ombudsman também pode atuar na área do direito do consumidor ${ }^{483}$.

Assim sendo, o ombudsman consiste em um indivíduo ou órgão governamental que atua de forma oficial pelo Estado, legitimado em determinadas áreas de atuação para resguardar os direitos dos cidadãos e investigar alegações de má administração pública. Seu papel é suplementar e não substitutivo das vias normais de queixas ou denúncias,

${ }^{479}$ WIEGAND, Shirley A. A Just and Lasting Peace: Supplanting Mediation with the Ombuds Model. Ohio State Journal on Dispute Resolution. v. 12, n. 1, p. 95-145, 1996, p.98. MALONEY, Arthur. The ombudsman idea. University of British Columbia Law Review. v. 13, Issue 2, p. 380-400, 1979, p. 380.

${ }^{480}$ Atualmente, o ombudsman em seu sentido original é adotado por diversos países, como Nova Zelândia, Austrália, Reino Unido e França.

${ }^{481}$ Destaca-se também a figura do Director General of Fair Trading na Finlândia.

${ }^{482} \mathrm{Na}$ Suécia existe também a figura do Ombuds que atua na proteção contra discriminação sexual nas relações trabalhistas.

483 CAPPELLETTI, Mauro. Os métodos alternativos de solução de conflitos no quadro do movimento universal de acesso à justiça. Revista de Processo, São Paulo. ano 19, n. 74, .82-97, 1994., p. 85. 
como tribunais administrativos ou representantes eleitos. Apesar de ser reconhecido como uma instituição eficiente, as investigações e procedimentos realizados por ele raramente possuem força de lei ${ }^{484}$.

Verifica-se que, no Direito dos Investimentos, além dos serviços mais próximos de aftercare (ou cuidado posterior) ${ }^{485}$, que incluem a assistência continuada para a promoção de investimentos através de agências de promoção de investimentos, vários países estão optando pela resposta institucional do ombudsman para enfrentar questões sensíveis. Para os investidores, um ombudsman fornece a possibilidade de um interlocutor institucional a quem recorrer, um canal oficial para abordar questões e problemas em seu estágio inicial ${ }^{486}$. Esse procedimento pode constituir um canal obrigatório ou estar disponível para o investidor como uma opção adicional, além disso, pode operar de acordo com procedimentos estritos ou mais flexíveis.

De qualquer forma, o escritório do ombudsman pode constituir uma forma de o investidor tentar uma resolução pronta, antecipada, potencialmente barata e amigável de um problema relacionado à matéria de investimentos. Para os Estados hospedeiros, o ombudsman consiste em um primeiro ponto de contato ou porta de entrada para se lidar com um problema suscitado por um investidor estrangeiro. Este pode fornecer informações preliminares às autoridades e possibilitá-las de resolver o problema e, também, facilitar uma ação rápida, se necessário, permitindo que as autoridades corrijam a questão antes que ela piore.

${ }^{484}$ HEYWOOD, Andrew. Politics. 4ed. New York: Palgrave Macmillan, 2013. p. 374.

${ }^{485}$ A atração de novos investidores em território estrangeiro consiste em uma atividade visivelmente voltada à promoção de investimentos. Nessa esteira, durante a instalação de novas filiais faz-se necessário também que o investidor conte com o apoio do governo local para que este o auxilie na instalação e reorganização do novo investimento, e para que este, posteriormente, se consolide. Esta função é, muitas vezes, uma das partes mais negligenciadas na promoção de investimentos, por esse motivo, desenvolveuse o conceito de aftercare ou preocupação posterior. Este conceito visa, primordialmente, que o tratamento dos investimentos seja cuidadosamente acompanhado pelo Estado, o que engloba todos os potenciais serviços oferecidos à companhia estrangeira pelo governo, a fim de facilitar a impulsão do investimento e seu contínuo desenvolvimento, com vistas também a maximizar sua contribuição ao desenvolvimento econômico da comunidade local. Nesse contexto, foram desenvolvidas muitas Agências de Promoção de Investimentos (APIs), que objetivam se engajar em dar suporte às empresas transnacionais, para que seu pós-estabelecimento se dê da forma menos custosa possível. Dentre os benefícios desse sistema, encontram-se a maior transferência de tecnologia, o desenvolvimento de uma cadeia de suprimentos globais e o aumento na criação de empregos. Assim, o custo de promover políticas de auxílio aos investidores é menos custoso que o preço de que estes procurem por uma nova locação, logo, se as empresas estão satisfeitas, estas promoverão o Estado receptor. Cf. YOUNG, S.; HOOD, N. Designing developmental after-care programmes for foreign direct investors in the European Union. Transnational Corporations, v.3, n.2, 1994. p. 45-72.

${ }^{486}$ UNITED NATIONS CONFERENCE ON TRADE AND DEVELOPMENT. Series on International Investment Policies for Development. Investor-State Disputes: Prevention and Alternatives to Arbitration. New York; Geneva: United Nations, 2010. p. 87. 
Ocorre que a habilidade do ombudsman ou do escritório do ombudsman em tomar ações corretivas ou requerer que estas sejam designadas por outra agência ou autoridade nacional irá depender de seu posicionamento institucional no governo. $\mathrm{Na}$ prática, o escritório do ombudsman localiza-se em agências de promoção de investimento, em nível central ou regional, com um Ministério ou uma entidade separada diretamente sob os auspícios do Primeiro Ministro ou do Presidente e pode tomar a forma de uma única autoridade ou de uma comissão composta por várias agências.

Também pode haver a criação de uma comissão conjunta composta por representantes dos Estados envolvidos no acordo de investimentos. Esse é o caso da Comissão para Cooperação Ambiental que auxilia na prevenção de potenciais conflitos comerciais e de meio ambiente relacionados ao NAFTA e que deve ser adaptada a potenciais disputas sobre investimentos. Em certa medida, as comissões conjuntas desempenham um papel preventivo e podem ser encontradas em diversos TBIs, em especial, nos chineses ${ }^{487}$.

Contudo, segundo Mauro Cappeletti, sua desvantagem reside no fato deste mecanismo tender a onerar a máquina estatal com mais burocracia e regulamentações, correndo o risco de ser "capturado" pelos próprios interesses que se esperava que controlasse" 488 . O autor cita o caso da Environmental Protection Agency, nos EUA, à época do governo Reagan, em que pode haver um declínio do zelo e do ativismo do órgão.

Um exemplo significativo da aplicação do ombudsman é a abordagem adotada pela Coreia do Sul. Em 1998, com a crise financeira asiática, fazia-se necessária a atração de mais investimentos para o território sul-coreano, por isso, o governo tomou partido da situação promulgando a Lei de Promoção de Investimentos Estrangeiros. Essa lei promovia um regime mais liberalizado de investimentos estrangeiros, e já em seu art. $1^{\circ}$ previa que seu propósito seria atrair investimentos oferecendo benefícios e assistência aos investidores ${ }^{489}$.

Entretanto, o dispositivo de destaque para o presente trabalho reside no art. 15(2), que estabelece um ombudsman para investidores estrangeiros para que possam endereçar

${ }^{487}$ UNITED NATIONS CONFERENCE ON TRADE AND DEVELOPMENT. Series on International Investment Policies for Development. Investor-State Disputes: Prevention and Alternatives to Arbitration. New York; Geneva: United Nations, 2010. p. 88.

${ }^{488}$ CAPPELLETTI, Mauro. Os métodos alternativos de solução de conflitos no quadro do movimento universal de acesso à justiça. São Paulo, ano 19, n.74, .82-97, 1994.p. 85.

${ }^{489}$ UNITED NATIONS CONFERENCE ON TRADE AND DEVELOPMENT. Proceedings of the Washington and Lee University and UNCTAD. Joint Symposium on international investment and alternative dispute resolution, held on 29 March 2010 in Lexington, Virginia, United States of America. New York and Geneva: United Nations, 2011. p. 98. 
suas queixas enquanto estiverem realizando seus negócios na Coreia do Sul. Foi estabelecido em 1999 o Office of the Foreign Investment Ombudsman (OFIO), instituição sem fins lucrativos, com mandato para enfrentar e resolver as dificuldades sentidas por empresas estrangeiras residentes na Coreia e para criar um ambiente mais favorável para investimentos, ao mesmo tempo em que atualiza o sistema administrativo e burocrático do país com os padrões globais.

O escritório do ombudsman sul coreano é reconhecido como um canal oficial em que as companhias estrangeiras podem recorrer para endereçar suas reclamações. Opera no âmbito da Korea Trade-Investment Promotion Agency (KOTRA) e sua direção é nomeada pelo Presidente da República, por recomendação do Ministro do Comércio, Indústria e Energia baseado em deliberação do Comitê de Investimentos Estrangeiros.

Sua função consiste em rastrear e resolver os problemas através de serviços de assessoria e em dar apoio ao investidor estrangeiro sobre como lidar com as legislações nacionais e dificuldades de gestão. Se a reclamação se referir a leis inadequadas ou obstáculos administrativos por parte do governo, o escritório do ombudsman pode ir além e aconselhar o investidor, propor a cooperação das autoridades governamentais e órgãos diretamente vinculados, para que hajam melhorias nas políticas de investimento, procedimentos administrativos ou em leis e regulamentos.

Assim sendo, as prerrogativas do ombudsman se estendem também a requerer a cooperação e a implementação de recomendações a agências administrativas, propor novas políticas governamentais para melhorar o sistema de promoção de investimentos e executar outras tarefas necessárias para conferir assistência às companhias estrangeiras para que resolvam suas questões ${ }^{490}$, o que e indiretamente, afeta as perspectivas e decisões de investimento de uma empresa.

Logo, a instalação de um escritório ou a nomeação de um ombudsman pode servir como um mecanismo bem aparelhado e satisfatório para a prevenção de controvérsias, bem como para dar apoio a investidores estrangeiros, como demonstrado no ordenamento jurídico sul-coreano, denominado como único por suas próprias entidades governamentais. À medida que os resultados do sistema são reconhecidos, esse tem servido como referência

${ }^{490}$ COREIA DO SUL. Office of the foreign investment ombudsman. Overview \& Mission. Disponível em: $<$ http://www.i-ombudsman.or.kr/eng/au/index.jsp?num=3>. Acesso em: 5 out. 2015 . UNITED NATIONS CONFERENCE ON TRADE AND DEVELOPMENT. Series on International Investment Policies for Development. Investor-State Disputes: Prevention and Alternatives to Arbitration. New York and Geneva: United Nations, 2010. p. 90-92. UNITED NATIONS CONFERENCE ON TRADE AND DEVELOPMENT. World Investment Report 2013: Global value chains: investment and trade for development. New York; Genebra: United Nations, 2013. p. 156. 
para a implementação de sistemas parecidos em outros países, como o que se vê atualmente com Rússia e Brasil ${ }^{491}$.

\subsubsection{Comissões Interministeriais de Alto Nível}

Outra estrutura institucional criada com a finalidade de evitar conflitos atinentes a investimentos é a instauração de comissões interministeriais de alto nível, que têm por objetivo evitar arbitragens investidor-Estado. Por intermédio dessas instituições visa-se uma avaliação antecipada da controvérsia pelas autoridades políticas máximas, o que, segundo Romulo Brillo, facilita a efetiva implementação das soluções indicadas ${ }^{492}$. Estas comissões atuam como possíveis instâncias de prevenção de controvérsias, recebendo queixas por parte dos investidores, possivelmente resultantes de violações dos APPRIs ou contratos de investimentos. $\mathrm{O}$ fato dessas comissões atuarem em nível bastante elevado na tomada de decisões faz com que suas decisões sejam mais efetivas. Contudo, caso os esforços dessas comissões falhem em prevenir a disputa, estas atuam também dando suporte ao principal organismo a cargo da coordenação da defesa do Estado nos procedimentos arbitrais mistos ${ }^{493}$.

Segundo a UNCTAD, países como Colômbia e Guatemala já têm implementado esse sistema. No primeiro caso, a Colômbia já tomou várias medidas para empreender esforços para identificar todas as autoridades reguladoras relevantes que podem se envolver em uma disputa e instalar comissões interministeriais. Para facilitar a comunicação entre elas, pontos de contato específicos (funcionários encarregados) em várias agências foram designados para lidar com questões relacionadas a investimentos. $\mathrm{O}$ principal órgão a cargo da defesa do Estado será a autoridade encarregada da coleta e produção de provas advindas de todas as fontes relevantes no seio do Governo colombiano. Já no segundo caso, o Decreto $n^{\circ} 128 / 2009$ estabeleceu temporariamente um mecanismo institucional para lidar com dois casos contra o país, através da criação de uma Comissão interministerial para lidar com esses casos pendentes, e o Ministério da Economia foi designado pelo decreto como agência coordenadora de defesa.

${ }^{491}$ COREIA DO SUL. Office of the foreign investment ombudsman. Notice \& Information. Disponível em: $<\mathrm{http} / /$ www.investkorea.org/ikwork/ombsman/eng/au/index.jsp?num=8\&no=609280001\&bno $=2081400$ 21\&page $1=1 \&$ sort_num $=534>$. Acesso em: 13 set. 2015.

492 BRILLO, Romulo. A prevenção de controvérsias investidor-Estado e alternativas à arbitragem investidorEstado In: RIBEIRO, Marilda Rosado de Sá. Direito Internacional dos Investimentos. Rio de Janeiro: Renovar, p. 271-299, 2014. p. 292.

${ }^{493}$ BRILLO, Romulo. Ibid. p. 293. 
Embora direcionados principalmente à preparação da defesa do Estado nos casos de arbitragem mista, o programa também tem outras funções relacionadas diretamente à prevenção e solução de controvérsias. Nesse sentido, a identificação e fortalecimento de uma agência líder contribui para permitir desde o início as discussões com o investidor lesado, garantindo a necessária cooperação e apoio da agência governamental ou entidade subnacional que analisou a reclamação em estágio inicial ${ }^{494}$.

\subsubsection{Prevenção de Controvérsia Setor a Setor}

Segundo a UNCTAD, a evidência empírica ao se analisar o volume de disputas sobre investimento demonstra que os investimentos estrangeiros em alguns setores e atividades econômicas são mais propensos a disputas entre o investidor e o Estado receptor. Da mesma forma, alguns compromissos jurídicos, tais como os contratos estatais complexos envolvendo concessões de serviços públicos, contratos Build-Operate-Transfer (BOT) ou arranjos de privatização são mais frequentes na origem dos litígios que outros tipos de instrumentos de investimento (dependendo também da extensão das obrigações do Estado). Estas disposições contratuais podem ter respaldo no direito nacional, como leis, regulamentos, práticas contratuais e, por que não, também, compromissos assumidos sob a égide dos tratados de investimento.

Nesse sentido, disputas surgiram em várias áreas, como por exemplo no que tange a contratos de concessão de serviços públicos, tais como a distribuição de água ou coleta de lixo, e projetos de mineração e extração de petróleo. A experiência dos países em lidar com políticas de prevenção de disputa mostra que um passo importante na criação destas políticas é a identificação dos chamados setores sensíveis da economia ou disposições contratuais sensíveis. Uma vez identificados, listado, estudados e monitorados de perto, podem ser instalar medidas preventivas efetivas a serem direcionadas a esses setores, para se evitar violações dos compromissos estabelecidos ou gerar quaisquer outros tipos de controvérsias.

Nesse ínterim, a experiência de outros países na política setorial preventiva pode ser útil na identificação de setores e atividades que são mais sensíveis à intervenção reguladora do Estado anfitrião. Um exemplo disso é o levantamento de reclamações de

${ }^{494}$ UNITED NATIONS CONFERENCE ON TRADE AND DEVELOPMENT. Series on International Investment Policies for Development. Investor-State Disputes: Prevention and Alternatives to Arbitration. New York and Geneva: United Nations, 2010. p. 82-83. 
investidores realizada atualmente pela agência de promoção de investimento da República Dominicana na implementação do DR-CAFTA ${ }^{495}$. Ademais, revisões de políticas de investimento realizadas pela UNCTAD, a pedido de seus países membros também podem fornecer orientações úteis para melhor direcionar os esforços e recursos para políticas mais eficientes de prevenção de litígios ${ }^{496}$.

\subsection{CONSIDERAÇÕES FINAIS}

Segundo Orrego Vicuña ${ }^{497}$, contemporaneamente, o mais significativo passo para o acesso direto de indivíduos aos mecanismos de solução de controvérsias foi promovido pela Convenção de Washington de 1965 com o estabelecimento do Centro Internacional para Resolução de Disputas sobre Investimentos entre Estados e Nacionais de Outros Estados. Esta iniciativa foi especificamente arquitetada para tornar os procedimentos de arbitragem e conciliação disponíveis para investidores estrangeiros e ao fazê-lo, evitar o recurso tradicional à proteção diplomática, por intermédio de um mecanismo despolitizado, e que possibilita que o particular inicie ou responda a uma demanda sem a intermediação de seu Estado de origem.

Apesar de ter tido um início tímido, atualmente o CIRDI é a jurisdição de maior destaque no que se refere à administração de procedimentos de conciliação e arbitragem mistos, os quais ocorrem tanto sob a égide das regras de conciliação e arbitragem do CIRDI, quanto por meio das regras de conciliação e arbitrais de seu Mecanismo Complementar. Entretanto, estas alternativas à arbitragem investidor-Estado não são as únicas presentes nos APPRIs, sendo também muito frequentes as remissões às regras de arbitragem da UNCITRAL e, em menor escala, aos regulamentos de arbitragem da CCI e da CCE.

Ressalta-se que o Brasil é tradicionalmente resistente à arbitragem de investimentos e ao CIRDI. Ao se analisar o parecer do Consultor Jurídico do Itamaraty,

${ }^{495}$ O Tratado de Livre Comércio República Dominicana-América Central (CAFTA-DR) é o primeiro acordo de livre comércio entre os Estados Unidos e um grupo de economias em desenvolvimento menores da América Central, como Costa Rica, El Salvador, Guatemala, Honduras, Nicarágua, bem como a República Dominicana.

${ }^{496}$ UNITED NATIONS CONFERENCE ON TRADE AND DEVELOPMENT. Series on International Investment Policies for Development. Investor-State Disputes: Prevention and Alternatives to Arbitration. New York and Geneva: United Nations, 2010. p. 74-75.

${ }^{497}$ ORREGO VICUÑA, Francisco. International Dispute Settlement in an evolving global society: constitutionalization, accessibility, privatization. Hersch Lauterpacht Memorial Lectures. Cambridge: Cambridge University Press, 2001. p.64. 
pôde-se verificar que o entendimento predominante era de que o Estado não necessita subrogar suas funções públicas essenciais, como a jurisdicional, a tribunal internacional, bem como o mecanismo arbitral do CIRDI violaria a soberania nacional. Assim sendo, mesmo tendo o parecer sido redigido na década de 1960, frisa-se que este é o argumento que predomina até os dias de hoje, haja vista o Brasil jamais ter assinado a Convenção de Washington de 1965.

Nesse ínterim, destaca-se que, concomitantemente ao sistema jurisdicional de solução de controvérsias sobre investimentos, existem também alternativas aos meios adjudicatórios. A primeira delas é a negociação direta, realizada inteiramente pelas partes, sem a intervenção de terceiros e que deve ser empreendida, de acordo com a teoria da negociação com base em interesses, sempre levando em consideração as necessidades e receios das partes à mesa de negociação, para que se obtenha o maior nível de satisfação possível. Salienta-se que esta teoria não é aplicada somente na negociação direta, mas também na negociação facilitada, que abrange processos baseados na intervenção de terceiros, como a mediação, a conciliação e o fact-finding.

Ademais, conclui-se que outra possibilidade que se aventa para as controvérsias sobre investimento é a de neutralizar o entrave em sua fase inicial, para que este não evolua e constitua disputa judicial futura. Para isso, utiliza-se os mecanismos preventivos de solução de controvérsias, dentre os quais, a figura do ombudsman é a que tem ganhado maior destaque nos últimos anos, em razão da experiência bem-sucedida de países como a Coreia do Sul, servindo até mesmo como inspiração para outros países, como se verá no capítulo 5 .

Entretanto, ao associar os mecanismos judiciais, alternativos e preventivos abordados com outra teoria trazida à baila neste capítulo - a teoria da sombra do direito tem-se que as negociações atinentes a investimentos, seja com a intervenção de terceiro ou não, somente progredirão entre as partes, se houver um mecanismo de solução de controvérsias jurisdicional que proveja previsibilidade dos possíveis resultados às partes, o que, aí sim, as levará a empenhar esforços à negociação. Ao analisar a arbitragem investidor-Estado percebe-se que esta possui tal qualidade, pois prevê-se que no mínimo haja um resultado arbitral, o que faz com que se delimite o âmbito de negociação e se incentive o cumprimento das disposições previstas nos acordos de investimento.

Nesse sentido, expostos os padrões de proteção nos acordos de investimentos e as formas de solução de controvérsias internacionais existentes, passa-se, no capítulo 5 , à apreciação do mecanismo de prevenção e solução de controvérsias engendrado nos ACFIs 
brasileiros e seu funcionamento, contextualizando-o com a teoria da sombra do direito aqui apresentada e, por fim, empreendendo análise da existência de incentivos concretos à negociação. 


\section{OS MECANISMOS DE PREVENÇÃO E SOLUÇÃO DE CONTROVÉRSIAS DOS ACFIS}

Ao se empreender um olhar mais atento aos ACFIs brasileiros, percebe-se que enquanto a proteção dos investimentos estrangeiros consiste em uma parte fundamental desses instrumentos, estes são mais ambiciosos no que tange à promoção de investimentos e à prevenção de conflitos $^{498}$. Ressalta-se que a opção brasileira por um reforço da governança institucional do acordo e na prevenção de controvérsias demonstra sua preocupação em encapsular entraves, para que estes não evoluam para uma possível controvérsia judicial. Caso os métodos preventivos não alcancem sucesso, os acordos elegem a arbitragem como próximo passo à resolução de disputas. Todavia, esta não constitui a tradicional arbitragem investidor-Estado contida nos TBIs, haja vista que o novo acordo brasileiro preferiu a escolha da arbitragem entre Estados.

Desse modo, conforme pontuam Cozendey e Cavalcante, os ACFIs partem da premissa de que "os Estados devem cooperar para auxiliar a realização e expansão de investimentos recíprocos" litígio, presente na forma como os APPIs tradicionais foram aplicados, e propõe o desenvolvimento de institucionalidade que fomente o diálogo entre o investidor e o Estado receptor dos investimentos $\$ 500$.

Assim sendo, este capítulo focar-se-á na análise nos pilares restantes dos ACFIs, quais sejam a governança institucional, por meio do Comitê Conjunto e dos Pontos Focais ou Ombudsman e as Agendas Temáticas de Cooperação. Ademais, focar-se-á também na prevenção e solução de controvérsias, pelo que será examinado o mecanismo jurisdicional estabelecido pelo acordo - a arbitragem Estado-Estado. Será abordado também o sistema de solução de controvérsias previsto no tratado bilateral de investimentos da Coreia do Sul e suas características. Entretanto, nesta parte, uma vez que o mecanismo preventivo de solução de controvérsias sul-coreano já foi abordado no capítulo anterior, apenas se fará

${ }^{498}$ PERRONE, Nicolás M.; CÉSAR, Gustavo Rojas de Cerqueira. Brazil's bilateral investment treaties: More than a new investment treaty model?. Columbia FDI Perspectives Perspectives on topical foreign direct investment issues. n. 159, p.1-3, October 26, 2015. Disponível em: $<$ http://ccsi.columbia.edu/files/2013/10/No-159-Perrone-and-C\%C3\%A9sar-FINAL.pdf $>$. Acesso em: 27 out 2015. UNITED NATIONS CONFERENCE ON TRADE AND DEVELOPMENT. World Investment Report 2015: Reforming international investment governance. New York and Geneva: United Nations, 2015. p. 107.

499 COZENDEY, Carlos Marcio Bicalho; CAVAlCANTE, Pedro Mendonça. Novas Perspectivas para Acordos Internacionais de Investimentos - o Acordo de Cooperação e Facilitação de Investimentos (ACFI). Cadernos de Política Exterior, Brasília, . v. 1, n. 2, p. 87-109, out. 2015. p.89.

${ }^{500}$ COZENDEY, Carlos Marcio Bicalho; CAVALCANTE, Pedro Mendonça. Ibid, p. 89. 
referência a este procedimento, que conta com a atuação do Ombudsman de investimentos sul-coreano.

Por fim, será empreendida análise crítica acerca do mecanismo de solução de controvérsias previsto nos ACFIs, contextualizando-o com a teoria da sombra do direito, de modo a extrair-se as supostas desvantagens quanto à opção da arbitragem entre Estados ao revés da arbitragem investidor-Estado.

\subsection{GOVERNANÇA INSTITUCIONAL}

Reconhecida como inovação nos acordos brasileiros, a governança institucional é um dos pilares do acordo de cooperação e facilitação de investimentos. Esta visa reforçar a promoção dos investimentos e a prevenção de controvérsias seja por meio da criação de um Comitê Conjunto, seja através do estabelecimento de Pontos Focais ou Ombudsman ${ }^{501}$. O objetivo principal desses órgãos é prover uma instância de governança que esteja atenta à implementação do acordo por meio de seu monitoramento contínuo, da interlocução com o setor privado, da prestação de informações quando necessário e da prevenção e solução de controvérsias.

A presença da governança institucional nos acordos de investimentos trata-se de estrutura recente, haja vista que, conforme pontuam Federico Ortino e Karl Sauvant, os APPRIs tradicionais não preveem um arcabouço permanente, por exemplo, com reuniões regulares das partes contratantes, com o estabelecimento de um organismo responsável pelo controle do cumprimento do acordo e pela interpretação das obrigações ou com o estabelecimento de um órgão permanente de resolução de litígios ${ }^{502}$.

Por isso, a opção das Partes por um reforço da governança institucional nos ACFIs demonstra sua preocupação, em supervisionar a aplicação do acordo, de melhorar a comunicação com as partes e, também, de resolver pacificamente as reclamações aventadas, de modo a evitar futuras disputas e encapsulando entraves frívolos, para que

${ }^{501}$ Sobre a governança institucional dos ACFIs, Fabrizio Panzini e Constanza Negri aduzem que: "é uma inovação nos acordos brasileiros e endereça uma crítica de que os ABIs em geral carecem de uma instância de governança para sua implementação". PANZINI, Fabrizio; NEGRI, Constanza. O retorno dos acordos de investimentos na agenda comercial brasileira. Revista Brasileira de Comércio Exterior. ano 29 n. 123 , p. 58-72, abr./jun. 2015. p. 69.

${ }^{502}$ SAUVANT, Karl; ORTINO, Federico. Improving the international investment law and policy regime: options for the future Helsinki. Ministry for Foreign Affairs of Finland, 2013. p. 41. Segundo os autores, a existência de um aparato que promova maior diálogo institucional com as partes pode servir como um interlocutor para se chegar também a outras partes interessadas, o que não inclui somente o setor privado quanto aos investidores, mas também aos representantes das comunidades locais e da sociedade civil como um todo. 
estes não evoluam para uma possível controvérsia judicial. Desse modo, passa-se à análise individual dos principais elementos que formam a governança institucional do novo acordo de investimentos brasileiro.

\subsubsection{Pontos Focais ou Ombudsman}

Em sua concepção clássica, segundo Shirley Wiegand, o ombudsman trata-se de estrutura administrativa designada pelo Estado para lidar com queixas e reclamações contra ações promovidas pela Administração Pública. Para o exercício de suas atividades, o funcionário deverá agir com as seguintes premissas: independência, competência, imparcialidade, acessibilidade e exercício de seus poderes de persuasão, ao invés de controle, para resolver as reclamações dos investidores ${ }^{503}$.

Nos ACFIs, o ombudsman - também chamado Ponto Focal - foi criado sob inspiração da Comissão para Cooperação Ambiental no âmbito do NAFTA, instituto que auxilia na prevenção de potenciais conflitos comerciais e ambientais e que pode ser adaptado a potenciais disputas de investimentos ${ }^{504}$, e, também, do modelo sul-coreano do Office of the Foreign Investment Ombudsman (OFIO), que opera no âmbito da Korea Trade-Investment Promotion Agency (KOTRA) ${ }^{505}$

$\mathrm{Na}$ Coreia do Sul, como já abordado anteriormente, o ombudsman consiste em um cargo comissionado, designado pelo Presidente da República, e que exige elevado conhecimento e experiência em matéria de investimentos ou comércio internacional, sendo assessorado por uma gama de experts em diversas áreas afins ${ }^{506}$. Seu serviço não possui custos para quem o procure e sua função consiste em coletar e analisar informações relativas aos problemas enfrentados pelas empresas estrangeiras, solicitar a cooperação e requerer a recomendação da implementação aos órgãos e agências administrativas

${ }^{503}$ WIEGAND, Shirley A. A Just and Lasting Peace: Supplanting Mediation with the Ombuds Model. Ohio State Journal on Dispute Resolution. v. 12, n. 1, p. 95-145, 1996. p. 98. MALONEY, Arthur. The ombudsman idea. University of British Columbia Law Review. v. 13, Issue 2, p. 380-400, 1979.

${ }^{504}$ UNITED NATIONS CONFERENCE ON TRADE AND DEVELOPMENT. Series on International Investment Policies for Development. Investor-State Disputes: Prevention and Alternatives to Arbitration. New York and Geneva: United Nations, 2010. p. 88.

${ }^{505}$ SOUZA, Renato Rezende de Campos. Cooperation and Facilitation Investment Agreement - CFIA. [apresentação de slides no World Investment Forum]. [s.1.], mai 2015. Disponível em: <http://unctadworldinvestmentforum.org/wp-content/uploads/2015/03/Brazil_side-event-Wednesday_modelagreements.pdf $>$. Acesso em: 15 set. 2015; UNITED NATIONS CONFERENCE ON TRADE AND DEVELOPMENT. World investment forum 2014: investing in sustainable development. IIA Conference - 16 October 2014. Daniel Godinho. Disponível em: <http://unctadworldinvestmentforum.org/wp-content/uploads/2014/10/Godinho.pdf $>$. Acesso em: 16 dez. 2014.

${ }^{506}$ COREIA DO SUL. Foreign Investment Promotion Act (Republic of Korea). Artigo 15-2(1). Disponível em: < http://legal.un.org/avl/pdf/ls/Shin_RelDocs.pdf $>$. Acesso em: 26 out. 2015. 
relevantes, propor novas políticas para melhorar o sistema de promoção de investimentos e desempenhar as tarefas necessárias para resolver os problemas dos investidores estrangeiros $^{507}$.

No presente contexto, como exposto pelo atual Ombudsman de Investimentos SulCoreano, Dr. Jeffrey I. Kim, o objetivo desta instituição consiste em auxiliar na melhora do clima de investimentos e promover o sucesso das companhias estrangeiras investidoras na Coreia, resolvendo as dificuldades que elas encontram em suas atividades negociais e em sua administração diária ${ }^{508}$.

Ressalta-se que, durante a elaboração dos dispositivos sobre prevenção de controvérsias nos ACFIs, autoridades governamentais brasileiras realizaram visita oficial ao escritório da KOTRA, na Coreia do Sul, para melhor compreender esse arranjo institucional $^{509}$, o que, aliado ao fato de o padrão sul-coreano ter sido reconhecido como iniciativa bem-sucedida por diversas instituições internacionais relevantes, como a UNCTAD e a $\mathrm{OCDE}^{510}$, motivou a adoção de provisão semelhante no acordo brasileiro.

${ }^{507}$ COREIA DO SUL. Foreign Investment Ombudsman Annual Report 2014. 2015, p.27-35. Disponível em: $<$ http://125.131.31.47/Solars7DMME/004/15Foreign_Investment_Ombudsman_Annual_Report2014. pdf $>$. Acesso em: 05 nov 2015. Assim sendo, segundo o Foreign Investment Ombudsman Annual Report 2014, a comunicação facilitada com os investidores estrangeiros tem consistido em elemento fundamental para a atração de investimentos estrangeiros, contribuindo para a maior condução de investimentos para o território sul-coreano

${ }^{508}$ Segundo comunicado do ombudsman sul-coreano: "OFIO's main task is to help improve the investment climate and promote the success of foreign-invested companies in Korea by resolving difficulties they face both in business activities and in day-to-day management". Cf. COREIA DO SUL. Ombudsman's message, 2015. Disponível em: <http://www.i-ombudsman.or.kr/eng/au/index.jsp>. Acesso em: 26 out. 2015.

${ }^{509}$ Em 2014, durante visita da delegação brasileira ao escritório da KOTRA, na Coreia do Sul, a delegação brasileira realizou diversos questionamentos sobre o quadro institucional do ombudsman sul-coreano (estrutura organizacional, tamanho e função), como são as relações com os governos locais, as qualificações para o ombudsman e as dificuldades enfrentadas no processo de resolução das reclamações. Nesta ocasião, o Dr. Choong Yong Ahn, ex-Ombudsman de Investimentos Estrangeiros e atual Presidente da Comissão Coreana de Cooperação Empresarial, que também estava presente, enfatizou que tanto o ombudsman quanto o serviço dos Home Doctors, para a prevenção de controvérsias, deve tornar-se um instrumento confiável de diálogo para as empresas estrangeiras investidoras, que sentem a necessidade de discutir seus problemas de forma confidencial. Ele também observou a necessidade de precisão na análise das características das queixas e de construir um consenso com as agências governamentais, explicando a gravidade da reclamação e os benefícios que uma solução negociada pode trazer. Cf. COREIA DO SUL. Ombudsman's Office. Sharing Korea's Investment Aftercare Knowhow. A Brazilian government delegation visited Korea for an in-depth discussion on Korea's Foreign Investment Ombudsman system. Disponível em: <http://www.investkorea.org/publish/data/bbs/bulletin/img/10/IKE_03_1410.pdf $>$. Acesso em: 15 set. 2015. COREIA DO SUL. Foreign Investment Ombudsman Annual Report 2014. $2015 . \quad$ p.15. Disponível em: <http://125.131.31.47/Solars7DMME/004/15Foreign_Investment_Ombudsman_Annual_Report2014.pdf >. Acesso em: 5 nov. 2015; UNITED NATIONS CONFERENCE ON TRADE AND DEVELOPMENT. World Investment Report 2015: Reforming international investment governance. New York and Geneva: United Nations, 2015. p. 156.

${ }^{510}$ UNITED NATIONS CONFERENCE ON TRADE AND DEVELOPMENT. World Investment Report 2015: Reforming international investment governance. New York and Geneva: United Nations, 2015,p.156; UNITED NATIONS CONFERENCE ON TRADE AND DEVELOPMENT. Proceedings of 
Segundo a UNCTAD, o ombudsman serve como um sistema one-stop-shop para as queixas aventadas, ou seja, proporciona aos investidores as soluções para todas as reclamações recebidas, para que essas possam alcançar resultados frutíferos e serem dissuadidas. Desse modo, o sucesso dessa instituição reside no fato de que o ombudsman fornece um interlocutor institucional aos investidores que recorrerem a ele, uma via oficial para tratar de questões e problemas ainda em estágio inicial. Logo, este mecanismo preventivo pode constituir uma forma menos custosa, rápida e amigável para resolver preliminarmente um problema relacionado a investimentos ${ }^{511}$.

De forma geral, os ACFIs preveem que cada Parte designará um Ponto Focal ou ombudsman, de caráter oficial e obrigatório, que terá a função de servir como um importante canal de comunicação e apoio entre investidores e o Estado receptor. Este Ponto Focal atuará dentro de um mandato e com obrigações pré-estabelecidas, podendo propor ações específicas em busca da melhoria da governança em investimentos ${ }^{512}$. Segundo os acordos, cada Parte deverá designar um único órgão ou autoridade para exercer as atribuições de Ponto Focal, o qual deverá reagir de forma célere às comunicações e solicitações governamentais e dos investidores da outra Parte. Do lado brasileiro, esta instituição será estabelecida no âmbito da CAMEX, variando a contraparte conforme o respectivo país com que se pactua o acordo.

Dentre as funções previstas nos ACFIs para o Ponto Focal ou ombudsman estão: (i) atender às diretrizes do Comitê Conjunto e interagir com o Ponto Focal ou ombudsman da outra Parte, em consonância com os termos do acordo; (ii) administrar as consultas e

the Washington and Lee University and UNCTAD Joint Symposium on international investment and alternative dispute resolution, held on 29 March 2010 in Lexington, Virginia, United States of America. New York;Geneva: United Nations, 2011; ORGANIZATION FOR ECONOMIC CO-OPERATION AND DEVELOPMENT. OECD Reviews of Regulatory Reform KOREA Progress in Implementing Regulatory Reform. OECD Publishing. Disponível em: <http://www.oecd.org/korea/41399033.pdf>. Acesso em: 26 out 2015; MOROSINI, Fábio; BADIN, Michelle Ratton Sanchez. The Brazilian Agreement on Cooperation and Facilitation of Investments (ACFI): A New Formula for International Investment Agreements? Investment Treaty News. Disponível em: $<$ https://www.iisd.org/itn/2015/08/04/the-brazilian-agreement-on-cooperation-and-facilitation-ofinvestments-acfi-a-new-formula-for-international-investment-agreements/>. Acesso em: 10 ago 2015

511 UNITED NATIONS CONFERENCE ON TRADE AND DEVELOPMENT. Series on International Investment Policies for Development. Investor-State Disputes: Prevention and Alternatives to Arbitration. New York and Geneva: United Nations, 2010, p.30; UNITED NATIONS CONFERENCE ON TRADE AND DEVELOPMENT. Series on International Investment Policies for Development. Investor-State Disputes: Prevention and Alternatives to Arbitration. New York and Geneva: United Nations, 2010, p. 87; NICOLAS, F., THOMSEN, S; BANG, M. Lessons from Investment Policy Reform in Korea. OECD Working Papers on International Investment, OECD Publishing, p.1-44, 2013. Disponível em: <http://dx.doi.org/10.1787/5k4376zqcpfl-en>. Acesso em: 15 set. 2015.

${ }^{512}$ BRASIL. Agência Brasileira de Promoção de Exportações e Investimentos. Boletim de Facilitação de Negócios Análise e estudos de Conjuntura Internacional. ano 2, ed. 3, 2015. Disponível em: $<$ http://arq.apexbrasil.com.br/portal/BoletimNegocios_Edicao03.pdf>. Acesso em: 26 out. 2015. 
reclamações da outra Parte ou dos investidores da outra Parte do acordo com as autoridades governamentais competentes e fazer, quando adequado, sugestões de modo a empreender soluções para os problemas levantados, informando posteriormente aos interessados sobre os resultados de suas sugestões; (iii) prevenir ou mitigar disputas e facilitar sua resolução, em coordenação com as autoridades governamentais e em colaboração com entidades privadas pertinentes; (iv) prestar informações tempestivas e úteis às Partes sobre questões normativas relacionadas a investimentos em geral ou a projetos específicos e (v) relatar ao Comitê Conjunto suas atividades e ações, quando apropriado.

Ademais, cada Parte disporá de regulamento interno próprio para o funcionamento de seu Ponto Focal ou ombudsman, prevendo expressamente, quando cabível, prazos para a execução de cada uma de suas atribuições e competências. Nesse ínterim, as Parte deverão fornecer meios e recursos para que o Ponto Focal possa desempenhar seus encargos, bem como garantir seu acesso institucional aos demais órgãos governamentais envolvidos na aplicação do acordo.

Uma das principais críticas aventadas até o momento sobre a estrutura proposta para os Pontos Focais refere-se à limitação de apenas os governos e os investidores serem os únicos legitimados como interessados a levar reclamações ao órgão. Segundo Bernasconi-Osterwalder e Brauch seria interessante ampliar o leque de interessados hábeis a propor tais reclamações para a comunidade local e a sociedade civil, visto que, levando em consideração os impactos desses investimentos, também deve haver aceitação local dos mesmos e licença para que estes operem. Ademais, ao conduzir qualquer tensão surgida entre investidores e a comunidade local desde o início do projeto, evitar-se-á a escalada do imbróglio para uma disputa legal ${ }^{513}$, o que, por conseguinte, também faz parte do sucesso da prevenção de controvérsias.

Além disso, observa-se que, enquanto o Ponto Focal é estruturado em nível nacional, constituindo parte do arcabouço administrativo do Estado, ele é governado internacionalmente (pelo menos em uma extensão mínima) pelo Comitê Conjunto, pelo que deve atender às recomendações deste, bem como relatar a ele suas atividades e ações quando aplicável. Esta estrutura de governança terá de ser raciocinada e conduzida

${ }^{513}$ BERNASCONI-OSTERWALDER, Nathalie; BRAUCH, Martin Dietrich. Comparative Commentary to Brazil's Cooperation and Investment Facilitation Agreements (CIFAs) with Mozambique, Angola, Mexico, and Malawi. International Institute for Sustainable Development (IISD), p.1-16, September 2015, p.6. Disponível em: <https:/www.iisd.org/sites/default/files/publications/commentary-brazil-cifasacfis-mozambique-angola-mexico-malawi.pdf $>$. Acesso em: 15 set.2015. 
cuidadosamente em nível doméstico, particularmente no caso do Brasil, visto que apesar de possuir órgão fixo como seu ombudsman, terá de se reportar a vários organismos distintos, dependendo do país com que se realizou o acordo, o que pode implicar em opiniões e orientações distintas, e por que não, até mesmo contraditórias ${ }^{514}$.

Desse modo, conclui-se que o ombudsman foi criado com o intuito de prover maior amparo às demandas dos investidores brasileiros, em particular, no que diz respeito ao apoio governamental junto ao governo do Estado receptor de investimentos. A real motivação desse instituto é obstruir a abertura de disputas frívolas ${ }^{515}$, que poderiam ser dissuadidas em estágio inicial, de forma mais célere e menos custosa ${ }^{516}$. Ainda, esse mecanismo influenciará também na obtenção mais rápida de informações relevantes para a operacionalização dos investimentos nos órgãos governamentais do Estado Anfitrião ${ }^{517}$, sempre buscando prover maior apoio aos investidores de qualquer das Partes.

\subsubsection{Comitê Conjunto}

Segundo Shotaro Hamamoto e Luke Nottag ${ }^{518}$, a nova geração de tratados bilaterais de investimentos e de acordos de livre comércio, além de muitos dos TBIs provenientes da velha geração, vêm instituindo em suas disposições a instauração de um comitê conjunto em que representantes do governo discutem e revisam a implementação e operacionalização do tratado ${ }^{519}$. As funções desses comitês não estão adstritas às questões interestatais, mas também abrangem a prevenção de controvérsias, para que estas não progridam ou ascendam em futuras disputas jurisdicionais.

Nesse ínterim, destaca-se o previsto no tratado bilateral de investimentos entre China e Uganda, no art. 9 (4), em que um comitê conjunto poderá ser estabelecido

\footnotetext{
${ }^{514}$ BERNASCONI-OSTERWALDER, Nathalie; BRAUCH, Martin Dietrich. Comparative Commentary to Brazil's Cooperation and Investment Facilitation Agreements (CIFAs) with Mozambique, Angola, Mexico, and Malawi. International Institute for Sustainable Development (IISD), p.1-16, September 2015, p.7. Disponível em: <https://www.iisd.org/sites/default/files/publications/commentary-brazil-cifasacfis-mozambique-angola-mexico-malawi.pdf $>$. Acesso em: 15 out. 2015.

${ }^{515}$ A indicação de controvérsias frívolas e reclamações vexatórias já foi identificada pela UNCTAD como preocupação no que concerne à arbitragem de investimentos de forma geral e, também, à arbitragem de investimentos no âmbito do NAFTA. Cf. UNITED NATIONS CONFERENCE ON TRADE AND DEVELOPMENT. Series on International Investment Policies for Development. Investor-State Disputes: Prevention and Alternatives to Arbitration. New York and Geneva: United Nations, 2010, p. xxxiii e p.19.

${ }^{516}$ PANZINI, Fabrizio; NEGRI, Constanza. O retorno dos acordos de investimentos na agenda comercial brasileira. Revista Brasileira de Comércio Exterior. Ano 29, n. 123, p.58-72, abr.-jun. 2015. p.70.

${ }^{517}$ PANZINI, Fabrizio; NEGRI, Constanza. Ibid., p.70.

${ }^{518}$ HAMAMOTO, Shotaro; NOTTAG, Luke. Japan In: BROWN, Chester (Ed.). Commentaries on selected model investment treaties. Oxford: Oxford University Press, p.393-424, 2013, p.372.

${ }^{519}$ HAMAMOTO, Shotaro; NOTTAG, Luke. Ibid., p. 372.
} 
compreendendo relevantes experts para resolver as disputas. Ou seja, a composição do Comitê Conjunto não deve ser aleatória, mas sim englobar especialistas que possam melhor contribuir para o resultado negociado ${ }^{520}$.

Um dos países que mais utiliza esta estrutura é os Estados Unidos. No acordo de livre comércio entre Estados Unidos e Coreia do Sul, que entrou em vigor em 2012, por exemplo, estabelece-se um Comitê Conjunto. No art. 22.2 do acordo foram estipuladas as previsões de funcionamento do Comitê, em que se estabeleceu encontros periódicos, a criação de grupos de trabalho ad hoc e a adoção de suas próprias regras procedimentais, as quais poderão ser revisadas a qualquer momento ${ }^{521}$. Ademais, o Comitê tem seu procedimento baseado nas regras do Joint Committee Rules of Procedure ${ }^{522}$. Destaca-se que, além dos Estados Unidos, muitos países asiáticos também preveem a instalação de um Comitê Conjunto e utilizam esse sistema, como é o caso do Camboja, China, Coreia do Sul, Japão, dentre outros.

No âmbito do quadro institucional estabelecido pelos ACFIs, encontra-se prevista a instalação de um Comitê Conjunto para a administração e gestão dos acordos e assessoramento das relações comerciais entre as partes. Este será composto por

${ }^{520}$ Ainda, o TBI entre China e Uganda prevê também que caso o Comitê Conjunto não alcance acordo, a disputa será encaminhada à arbitragem ad hoc investidor-Estado. Cf. SHAN, Wenhua; GALLAGHER, Norah. China. In: BROWN, Chester (Ed.). Commentaries on selected model investment treaties. Oxford: Oxford University Press 2013., p.393-424. p. 172.

${ }^{521}$ Segundo a redação do art. 22.2 do Acordo de Livre Comércio EUA-Coreia do Sul: "Article 22.2: JOINT COMMITTEE 1. The Parties hereby establish a Joint Committee comprising officials of each Party, which shall be cochaired by the United States Trade Representative and the Minister for Trade of Korea, or their respective designees. 2. The Joint Committee shall: (a) supervise the implementation of this Agreement; (b) supervise the work of all committees, working groups, and other bodies established under this Agreement; (c) consider ways to further enhance trade relations between the Parties; (d) seek to resolve disputes that may arise regarding the interpretation or application of this Agreement; (e) establish the amount of remuneration and expenses that will be paid to panelists; and (f) consider any other matter that may affect the operation of this Agreement. 3. The Joint Committee may: (a) establish and delegate responsibilities to ad hoc and standing committees, working groups, or other bodies; (b) seek the advice of non-governmental persons or groups; (c) consider amendments to this Agreement or make modifications to the (d) issue interpretations of the provisions of this Agreement, including as provided in Articles 11.22 (Governing Law) and 11.23 (Interpretation of Annexes); (e) adopt its own rules of procedure; and (f) take such other action in the exercise of its functions as the Parties may agree. 4. Unless the Parties otherwise agree, the Joint Committee shall convene: (a) in regular session every year, with such sessions to be held alternately in the territory of each Party; and (b) in special session within 30 days of the request of a Party, with such sessions to be held in the territory of the other Party or at such location as the Parties may agree". Cf. OFFICE OF THE UNITED STATES TRADE REPRESENTATIVE. KORUS FTA. Chapter Twenty-Two Institutional Provisions and Dispute Settlement. Disponível

em: $<$ https://ustr.gov/sites/default/files/uploads/agreements/fta/korus/asset_upload_file973_12721.pdf $>$. Acesso em: 27 out. 2015.

522 OFFICE OF THE UNITED STATES TRADE REPRESENTATIVE. KORUS FTA. Rules of Procedure for the Joint Committee. Disponivel em: $<$ https://ustr.gov/sites/default/files/uploads/agreements/morocco/pdfs/5-16$12 \% 20$ KORUS $\% 20 J$ oint $\% 20$ Committee $\% 20$ Rules $\% 20$ of $\% 20$ Procedure $\% 20$ Final.pdf $>$.Acesso em: 26 out. 2015 . 
representantes governamentais de ambos os Estados Partes, que serão designados por seus respectivos governos. Nota-se que os acordos brasileiros também salientam a periodicidade de reuniões do Comitê, prevendo que este irá se reunir no mínimo uma vez ao ano, em datas e locais a serem designados pelos Estados, havendo presidências alternadas entre as Partes, qualidades estas que contribuem para a dinamicidade desse instituto.

Nesse contexto, conforme previsto nos ACFIs, o escopo do Comitê Conjunto consiste principalmente em: (i) monitorar a implementação dos ACFIs; (ii) discutir e compartilhar oportunidades de investimentos recíprocos; (iii) coordenar a implementação das agendas de cooperação e facilitação; (iv) solicitar e acolher a participação do setor privado e da sociedade civil, quando apropriado, em questões pontuais relacionadas aos trabalhos do Comitê; e (v) resolver amigavelmente quaisquer questões ou controvérsias sobre investimentos.

Quanto ao último objetivo, que se trata do foco deste capítulo, ressalta-se que ao Comitê Conjunto foi delegada a função de conduzir a composição das partes quando da existência de uma controvérsia jurídica. Ainda não está claro como se dará esse procedimento, entretanto, cumpre destacar que este pode ser um processo importante para a instalação de um mecanismo preventivo ${ }^{523}$ que busque uma solução negociada, levando em consideração o interesse das partes.

Partindo-se de uma análise individualizada dos ACFIs, tem-se que o acordo com Angola não possui maior detalhamento relativo à solução de controvérsias entre as Partes, e direciona ao Comitê Conjunto a função de definir ou elaborar um mecanismo padrão para resolver as disputas mediante arbitragem entre Estados. Assim, como esse sistema de solução de controvérsias ainda não se encontra bem delineado, seja no que concerne à composição do tribunal arbitral, à estipulação de prazos e quesitos para a escolha de árbitros, seja quanto ao reconhecimento e execução do laudo arbitral, dentre outras provisões, caberá ao Comitê proceder com todos esses elementos.

Em contrapartida, no ACFI com a Colômbia a redação é um pouco distinta. Designa-se que o Comitê terá a função de desenvolver regramentos complementares de solução de controvérsias arbitrais (se for o caso), ou seja, conforme este acordo, não é atribuição originária do Comitê delimitar o funcionamento do mecanismo arbitral de

${ }^{523}$ BERNASCONI-OSTERWALDER, Nathalie; BRAUCH, Martin Dietrich. Comparative Commentary to Brazil's Cooperation and Investment Facilitation Agreements (CIFAs) with Mozambique, Angola, Mexico, and Malawi. International Institute for Sustainable Development (IISD), p.1-16, September 2015, p.5. Disponível em: <https://www.iisd.org/sites/default/files/publications/commentary-brazil-cifasacfis-mozambique-angola-mexico-malawi.pdf $>$. Acesso em: 15 set. 2015. 
solução de controvérsias, apenas de complementá-lo em consonância com as regras já existentes. Noutro giro, o ACFI com México não delega ao Comitê Conjunto a função de formular regras para a resolução de controvérsias entre Estados, porém, dispõe que este atuará em sua implementação ${ }^{524}$.

Adicionalmente, o ACFI com a Colômbia acrescenta ainda ao Comitê Conjunto o encargo de analisar, caso a caso, quando uma das Partes, não respaldada nos preceitos da utilidade pública ou no interesse social, adota uma medida que impacta economicamente de forma grave um investimento de um investidor da outra Parte, prejudicando-o.

Ademais, assim como nos outros acordos que contêm a previsão do Comitê Conjunto, os acordos brasileiros também estabelecem que as Partes poderão instaurar grupos de trabalho ad hoc, que se reunirão em conjunto com o Comitê ou autonomamente, sendo que o setor privado poderá ser convidado a integrar esses grupos mediante autorização do Comitê.

Nesse ínterim, destaca-se que o ACFI com Angola expressamente permite que o Comitê Conjunto convide organizações não-governamentais (ONGs) para que representem a sociedade civil em certos assuntos. Observa-se que, do ponto de vista da participação da sociedade civil, trata-se de previsão interessante, a qual poderá ser desenvolvida e melhor explorada no futuro, haja vista que esta participação poderá chamar a atenção do Comitê para determinados tipos de comportamentos ou preocupações da comunidade local com relação a investimentos específicos no território do Estado Anfitrião. Ademais, incluir o setor privado e a sociedade civil em certas áreas de atuação pode também levar a novas oportunidades de cooperação em investimentos assim como a alcançar soluções mutuamente aceitáveis a todos.

Por fim, Bernasconi-Osterwalder e Brauch propõem que, de forma similar ao Comitê Conjunto previsto no art. 11.22, $\S 3^{0525}$, do acordo de livre comércio Estados Unidos-Coreia do Sul e outros acordos de livre comércio dos quais os EUA fazem parte, os futuros Comitês Conjuntos dos ACFIs poderiam também ser empoderados para questionar interpretações vinculantes (to issue binding interpretations), o que poderia auxiliar no

\footnotetext{
${ }^{524}$ Por fim, os outros acordos, com Malaui e Moçambique, não possuem previsão específica sobre a elaboração normativa para a solução de disputas.

${ }^{525}$ Segundo o art. 11:22 do Acordo de Livre Comércio entre Estados Unidos e Coreia do Sul: “Article 11.22: GOVERNING LAW. [...] 3 A decision of the Joint Committee declaring its interpretation of a provision of this Agreement under Article 22.2.3(d) (Joint Committee) shall be binding on a tribunal, and any decision or award issued by a tribunal must be consistent with that decision". Cf. ACORDO de livre comércio entre Estados Unidos da América e República da Coreia. Disponível em: $<$ http://investmentpolicyhub.unctad.org/Download/TreatyFile/2542>. Acesso em: 07 nov 2015.
} 
esclarecimento do significado de certos dispositivos dos tratados sem que houvesse necessidade de emenda formal às negociações ${ }^{526}$.

\subsubsection{Troca de Informações entre as Partes}

Os ACFIs também possuem previsões específicas acerca da troca de informações entre as Partes, em especial por meio do Comitê Conjunto e de seus Pontos Focais. Essa iniciativa torna-se extremamente importante à promoção de investimentos ao passo que proporcionará a permuta de oportunidades de negócios, procedimentos e requisitos exigidos à realização dos mesmos no território das Partes, conferindo maior transparência e acesso facilitado a todos esses quesitos ${ }^{527}$.

Com este instrumento, atende-se a uma das principais demandas do setor privado brasileiro, o maior domínio sobre as disposições regulatórias da outra Parte quanto a tratados internacionais, leis, regulamentos, licenças, condições específicas para negócios e políticas públicas nos mais diversos âmbitos, como investimentos (incluída legislação relativa ao estabelecimento de empresas e joint ventures), câmbio, trabalho e previdência, imigração, setores econômicos característicos, incentivos específicos e regime tributário e aduaneiro em vigor, informações sobre a infraestrutura e serviços públicos disponíveis, estatísticas sobre os mercados internos de bens e serviços, compras governamentais e concessões públicas, projetos regionais e acordos em matéria de investimentos existentes e informações públicas acerca de parcerias público-privadas. Assim sendo, um maior conhecimento em todas essas esferas regulatórias capacita o fomento de um ambiente favorável para os investimentos ${ }^{528}$.

\footnotetext{
${ }^{526}$ BERNASCONI-OSTERWALDER, Nathalie; BRAUCH, Martin Dietrich. Comparative Commentary to Brazil's Cooperation and Investment Facilitation Agreements (CIFAs) with Mozambique, Angola, Mexico, and Malawi. International Institute for Sustainable Development (IISD), p.1-16, September 2015, p.6. Disponível em: <https://www.iisd.org/sites/default/files/publications/commentary-brazil-cifasacfis-mozambique-angola-mexico-malawi.pdf>. Acesso em: 15 set. 2015.

${ }^{527}$ Vale ressaltar que a troca de informações é instituto também utilizado no âmbito Direito Tributário Internacional quando, por exemplo, da coleta e troca automática de informações sobre contas em instituições financeiras nos EUA e de residentes em outros países. Cf. SCHOUERI, Luís Eduardo; GALENDI JÚNIOR, Ricardo André. Transparência fiscal e reciprocidade nas perspectivas interna e internacional. In: ROCHA, Valdir de Oliveira. Grandes Questões Atuais do Direito Tributário, v. 19. São Paulo: Dialética, p. 248-287. 2015. p. 256-257.

${ }^{528}$ BERNASCONI-OSTERWALDER, Nathalie; BRAUCH, Martin Dietrich. Comparative Commentary to Brazil's Cooperation and Investment Facilitation Agreements (CIFAs) with Mozambique, Angola, Mexico, and Malawi. International Institute for Sustainable Development (IISD), p.1-16, September 2015, p.7. Disponível em: <https://www.iisd.org/sites/default/files/publications/commentary-brazil-cifasacfis-mozambique-angola-mexico-malawi.pdf $>$. Acesso em: 15 out. 2015.
} 
Ademais, nos ACFIs encontra-se previsto que as partes se empenharão com o câmbio de informações, se comprometendo a fornecer, quando solicitadas e com celeridade, os subsídios solicitados, e respeitarão inteiramente os padrões internos de proteção concedidos a tal informação, em consonância com as respectivas legislações internas acerca da matéria.

\subsubsection{Relação com o Setor Privado}

Em complemento à cláusula anteriormente abordada, os acordos reconhecem também o papel fundamental do setor privado, porquanto este é o maior interessado nestes procedimentos para que se possa alcançar um melhor ambiente de negócios. Nesse diapasão, salienta-se que os ACFIs com Angola e Moçambique abordam mais enfaticamente esse papel do setor privado, ao apontarem que as Partes deverão encorajar o setor privado "enquanto interveniente fundamental e diretamente interessado nos resultados dos acordos" ${ }^{\text {} 29}$ (grifos nossos).

Nesse contexto, todos os ACFIs estipulam que as Partes do acordo se comprometem a envolver e a disseminar, nos setores empresariais pertinentes, as informações de caráter geral sobre os investimentos, os marcos regulatórios que regem a matéria, bem como outras áreas de interesse para suas atividades e informações relativas às oportunidades de negócios no território das Partes.

Essa iniciativa se torna de suma importância, primeiramente, ao considerar que por meio dessa troca de informações entre as Partes e o setor privado estreita-se o canal de comunicação entre eles. Em segundo lugar, com a divulgação dessas informações para os investidores concretiza-se de fato a promoção dos investimentos em território nacional, porquanto com maiores esclarecimentos sobre as realidades e possibilidades de fomento de sua atividade econômica e sobre o sistema legislativo doméstico, os investidores podem vislumbrar maiores oportunidades de negócios. Ainda, com este envolvimento do setor privado, atende-se também às preocupações do setor privado no que concerne falta de informação sobre a legislação nacional e práticas administrativas necessárias à implementação e condução dos investimentos.

${ }^{529}$ BRASIL. Acordo e Cooperação e Facilitação de Investimentos entre a República Federativa do Brasil e o Governo da República de Moçambique. Maputo, 30 de março de 2015. Disponível em: $<$ http://www.itamaraty.gov.br/index.php?option=com_content\&view=article\&id=8511:acordo-brasilmocambique-de-cooperacao-e-facilitacao-de-investimentos-acfi-maputo-30-de-marco-de$2015 \&$ catid $=42 \&$ Itemid $=280 \&$ lang $=$ pt-BR $>$. Acesso em: 30 set. 2015 . art. $7^{\circ}$. 


\subsubsection{Tratamento da Informação Protegida}

Nesse sentido, havendo a troca de informações entre as Partes, em alguns casos, há certas circunstâncias previstas nas legislações nacionais, em que estas informações devem ser protegidas, seja em função dessas relacionarem-se a informações privilegiadas, serem relacionadas ao interesse e a segurança nacionais, à manutenção da ordem tributária e financeira, dentre outras possibilidades, seja por essas informações sigilosas envolverem entes privados, resguardados pelo direito de privacidade das pessoas físicas ou jurídicas, e de seus negócios.

A previsão de tratamento de informação protegida encontra-se apenas no acordo de cooperação e facilitação de investimentos com a Colômbia. Sua motivação consiste em reforçar o compromisso das Partes com o respeito ao nível de proteção da informação estabelecido pela Parte que a tenha apresentado, em observância às respectivas legislações internas sobre a matéria. Desse modo, esclarece-se que para o ACFI com a Colômbia, por informação protegida entende-se aquelas sigilosas de negócios ou as privilegiadas ou protegidas contra divulgação pública, de acordo com o previsto nas leis domésticas das Partes aplicáveis ao sigilo da informação protegida.

Ademais, nada no acordo será interpretado a fim de exigir de qualquer das Partes a divulgação de informação protegida, cuja exposição pudesse dificultar a aplicação da lei ou, de outra maneira, fosse contrária ao interesse público, ou até mesmo pudesse prejudicar a privacidade ou interesses comerciais legítimos. Portanto, conclui-se que a informação protegida, ou seja, aquela de cunho negocial, provavelmente relacionada à atividade econômica do investidor, deve ser resguardada, bem como também o deve ser aquelas que são reconhecidas como não divulgáveis publicamente e as informações que, caso saiam do sigilo impliquem em prejuízo ao interesse público, à privacidade e aos interesses comerciais devidos.

\subsection{AGENDAS TEMÁTICAS PARA COOPERAÇÃO E FACILITAÇÃO DE INVESTIMENTOS}

Examinados os pilares da governança institucional e dos mecanismos para mitigação de riscos e prevenção de disputas, o último pilar fundamental dos ACFIs trata-se das agendas temáticas de negociação para promover a cooperação e facilitação de 
investimentos ${ }^{530}$. Esta diretriz aparece como distinção positiva nos acordos brasileiros, vez que traz à baila compromissos que visam proporcionar condições de maior facilidade para a realização dos negócios, à promoção e ao incremento dos investimentos bilaterais.

A ideia por detrás destas agendas foi desenvolvida, principalmente, diante das demandas do setor privado em razão da burocracia enfrentada ao instalar suas empresas no exterior, como entraves na remessa de divisas e capitais, dificuldades nos procedimentos para a concessão de vistos, licenciamentos e certificações ambientais e demais problemas legais no que concerne à implementação das legislações setoriais. Dessa forma, como aduzem Panzini e Negri, as agendas temáticas, dependendo do que for incluído e acordado pelas Partes, podem focar-se em temas particulares que poderão auxiliar na redução da burocracia e dos custos das atividades econômicas dos investidores, citando-se aqui o exemplo concreto da facilitação de vistos já incluída com Angola e Moçambique ${ }^{531}$.

Os temas e objetivos a serem coordenados e implementados pelo Comitê abarcam justamente o compromisso de facilitar: (i) a remessa de divisas e capitais entre as Partes, no escopo do quadro legal aplicável ${ }^{532}$; (ii) a obtenção de vistos - no que se refere a prazos de validade e estadia, direito de múltiplas entradas e maior celeridade no procedimento de concessão - e (iii) a livre circulação de funcionários que tenham o intuito de realizar atividades que sejam ligadas ao investimento ${ }^{533}$.

Além disso, essas agendas temáticas também abarcam iniciativas de cooperação nos seguintes âmbitos: (i) cooperação entre Estados no que tange à promoção de intercâmbio de experiências legislativas setoriais e na elaboração e gestão de outros marcos regulatórios; (ii) cooperação tecnológica, científica e cultural mediante ações mútuas; ações conjuntas para a capacitação de mão de obra; (iii) criação de foros de cooperação

${ }^{530}$ UNITED NATIONS CONFERENCE ON TRADE AND DEVELOPMENT. World investment forum 2014: investing in sustainable development. IIA Conference - 16 October 2014. Daniel Godinho. Disponível em: <http://unctad-worldinvestmentforum.org/wp-content/uploads/2014/10/Godinho.pdf $>$. Acesso em: 16 dez. 2014.

${ }^{531}$ PANZINI, Fabrizio; NEGRI, Constanza. O retorno dos acordos de investimentos na agenda comercial brasileira. Revista Brasileira de Comércio Exterior, ano 29, n. 123, p. 58-72, abr.-jun. 2015. p.70.

532 O ACFI com Moçambique especifica, no Anexo I, que as autoridades monetárias dos Estados, respectivamente o Banco Central do Brasil, a Agência Brasileiras de Cooperação e o Banco de Moçambique, tratarão dos temas previamente identificados, como gestão de riscos; sistema de pagamentos; inclusão financeira; auditoria interna; gestão documental, de contratos e patrimônio; planejamento estratégico e recursos humanos e novos temas que venham a surgir.

${ }^{533}$ UNITED NATIONS CONFERENCE ON TRADE AND DEVELOPMENT. Op.cit; UNITED NATIONS CONFERENCE ON TRADE AND DEVELOPMENT. Investment policy monitor. n.14, October 2015, p.5-6. Disponível

em: $<$ http://unctad.org/en/PublicationsLibrary/webdiaepcb2015d14_en.pdf?utm_source=World+Investment + Network+\%28WIN\%29\&utm_campaign=1daa03da05-

Blog+Post+\%231\&utm_medium $=$ email\&utm_term=0_646aa30cd0-1daa03da05-70020601>. Acesso em: 27 out. 2015. 
para a troca de experiências de economia solidária, avaliando mecanismos de fomento a cooperativas, programas de agricultura familiar, dentre outros empreendimentos solidários; (iv) cooperação para o fomento de maior integração logística e de transportes, como empenhar-se na abertura de novas rotas aéreas, incrementando as rotas marítimas e frotas mercantes já existentes; e (v) cooperação institucional para o desenvolvimento e planejamento energético, inclusive na gestão de entidades transfronteiriças, além de modelos de preservação ambiental e gestão de carbono e água ${ }^{534}$.

A implementação e evolução das Agendas Temáticas serão efetuadas por meio de discussões entre as autoridades governamentais competentes de ambas as Partes, e após realizadas análises conjuntas, estas resultarão em protocolos adicionais aos acordos ou instrumentos jurídicos próprios, com o intuito de se avançar nas respectivas agendas temáticas e nos compromissos futuros.

Ademais, o ACFI com a Colômbia aduz, em seu art. 24, $\S 6$, que, para maior clareza, o propósito da cooperação deve ser compreendido em um sentido amplo, e não apenas em um viés de cooperação ou assistência técnica ou similar. Assim sendo, pode-se afirmar que colocando todas essas áreas em prática haverá maior entendimento mútuo em temas que possam suscitar entraves burocráticos às partes, bem como gerará maior intercâmbio institucional e de experiências em temas relevantes para todos, reduzindo-se os custos das atividades das empresas.

De todo modo, conforme salientam Michelle Badin e Fábio Morosini, as agendas temáticas acabam expressando o entendimento de que o benefício para o país de origem não deve vir exclusivamente da exportação de capitais ao Estado Anfitrião, mas também do impacto global que o investimento terá nesta nação ${ }^{535}$, elevando o nível de cooperação nas mais diversas áreas e, consequentemente, trazendo benefícios nas esferas econômicas, sociais, legislativas, logísticas e, até mesmo, energéticas ${ }^{536}$.

\footnotetext{
${ }^{534}$ O ACFI com o México é bem sucinto ao prever a facilitação de pagamentos e transferências de capital e divisas entre as Partes; a facilitação na concessão de vistos; a facilitação na expedição de licenças ambientais e outros documentos relacionados ao investimentos e cooperação institucional para o intercâmbio de experiências sobre o desenvolvimento e gestão de marcos regulatórios.

${ }^{535}$ MOROSINI, Fábio; BADIN, Michelle Ratton Sanchez. The Brazilian Agreement on Cooperation and Facilitation of Investments (ACFI): A New Formula for International Investment Agreements? Investment Treaty News. Disponível em: < https://www.iisd.org/itn/2015/08/04/the-brazilian-agreementon-cooperation-and-facilitation-of-investments-acfi-a-new-formula-for-international-investmentagreements/>. Acesso em: 10 ago. 2015.

${ }^{536}$ Contudo, observa-se que esses acordos podem acobertar desigualdades no futuro ao passo que a ideia de facilitação do investimento, na prática, pode não cobrir a todos os investidores de forma igual, mas principalmente as empresas que detém maior poder financeiro e influência junto a seus governos de origem e, também, nos Estados receptores de investimentos.
} 


\title{
5.3 PREVENÇÃO DE CONTROVÉRSIAS NOS ACFIs
}

Ressalta-se que, no mecanismo de prevenção de controvérsias, o ombudsman atua como primeira fase preventiva, haja vista que, no âmbito dos ACFIs, havendo qualquer problema ou reclamação, o investidor a levará ao Ponto Focal ou ombudsman, que empreenderá esforços para mitigar os riscos existentes, administrando a controvérsia, em coordenação com as autoridades governamentais e em colaboração com entidades privadas pertinentes e promovendo a negociação entre as partes, levando em consideração os interesses de ambas. Segundo Cozendey e Cavalcante (2015, p. 107-108):

\begin{abstract}
Cabe ao Ponto Focal receber questionamentos do investidor, que podem ser dúvidas sobre legislação aplicável ou oportunidades de investimentos, ou ainda podem ser questionamentos sobre situações específicas, como a demora na obtenção de alguma licença necessária para a operação de um investimento. $\mathrm{O}$ Ponto Focal analisa o questionamento do investidor e o encaminha para seus contatos nos órgãos diretamente responsáveis pelo tema específico da dúvida ou dificuldade enfrentada pelo investidor. O objetivo é colocar à disposição do investidor estrangeiro no Brasil, e do Brasil no exterior, meios de orientação e solução efetiva das dificuldades para realizar o investimento de forma a alentar os investimentos recíprocos ${ }^{537}$.
\end{abstract}

Esses pontos focais deverão, portanto, interagir com os investidores estrangeiros que se sentirem prejudicados de forma a mitigar as reclamações levadas até eles, propondo, ao final, sugestões para que estas se resolvam. Como caberá a cada parte adotar seu próprio regulamento acerca do funcionamento de seu Ponto Focal ou Ombudsman, com os prazos cabíveis e competências, não caberá detalhar isso no presente trabalho, pois ainda não há regulamento publicado dos institutos de nenhuma das partes dos acordos.

Entretanto, caso a via preventiva do Ponto Focal ou Ombudsman não alcance sucesso, há ainda a opção pelo Comitê Conjunto. Contudo, neste, distintamente da fase anterior, os legitimados para apresentar a reclamação não são exatamente os mesmos, visto que o investidor não possui mais o direito de pleito nesta fase. A parte legitimada a atuar junto ao Comitê, neste caso, é apenas o Estado de origem do investidor, que poderá submeter as dificuldades aventadas pelo investidor com relação ao Estado receptor ao crivo do Comitê Conjunto e solicitar uma reunião com este organismo, que deverá ocorrer em 30 dias da solicitação. Para que este procedimento se inicie, a Parte deverá apresentar a solicitação por escrito, especificando o nome do investidor afetado e as questões

537 COZENDEY, Carlos Marcio Bicalho; CAVALCANTE, Pedro Mendonça. Novas Perspectivas para Acordos Internacionais de Investimentos - o Acordo de Cooperação e Facilitação de Investimentos (ACFI). Cadernos de Política Exterior, Brasília, v. 1, n. 2, p.87-109, out. 2015. p.107 e 108. 
enfrentadas. O Comitê, por sua vez, terá o prazo de 60 dias, o qual pode ser prorrogado por igual período, de comum acordo e mediante justificativa, para que avalie as informações pertinentes ao caso e prepare um relatório.

Observa-se que, de forma a auxiliar a resolução do caso, sempre que possível, poderão participar da reunião do Comitê Conjunto os representantes dos investidores afetados e os representantes das entidades governamentais ou não governamentais envolvidas na medida ou situação do objeto de consulta, iniciativa esta que abre espaço para a participação também da sociedade civil na condição de também afetada.

Nesse caso, faz-se a ressalva de que, mesmo possibilitando a presença do representante do investidor na reunião bilateral do Comitê Conjunto, este continuará sem ter legitimidade de ação para a propositura da reclamação no Comitê, o que faz toda a diferença, ao se considerar que a queixa só será prevenida neste âmbito, e o representante somente poderá estar presente na reunião, se o Estado de origem do investidor assim o quiser lá atrás, quando decidir sobre remeter a reclamação ao Comitê Conjunto.

Nesse sentido, ocorrerá o processo de diálogo e consulta bilateral entre as Partes, para o alcance da melhor solução considerando os interesses das Partes, que deverá contar com o empenho destas, e se encerrará por iniciativa de qualquer um dos envolvidos após esgotados os 60 dias, mediante o relatório efetuado pelo Comitê Conjunto e apresentado na reunião subsequente, convocada 15 dias contados da data em que a Parte tenha requerido o encerramento das conversas e consultas ${ }^{538}$. Segundo o ACFI com o México, caso uma das Partes não compareça à reunião estabelecida pelo Comitê Conjunto para a instauração de diálogo e consultas bilaterais, a controvérsia poderá ser submetida à arbitragem EstadoEstado pela outra Parte.

Ainda, os acordos detalham os requisitos formais obrigatórios a estarem contidos no relatório preparado pelo Comitê Conjunto, quais sejam: (i) identificação da Parte; (ii) identificação do investidor afetado; (iii) descrição da medida objeto da consulta; (iv) relação das gestões efetuadas; e (v) posicionamento das Partes quanto à medida. Ademais, ressalta-se que as reuniões do Comitê, bem como toda a documentação entregue a ele e as medidas adotadas no âmbito do mecanismo estabelecido serão reservadas, com exceção dos relatórios apresentados.

Entretanto, caso neste âmbito institucional não se consiga promover o acordo entre as partes legitimadas, resta ainda a opção pelos meios jurisdicionais internacionais de

\footnotetext{
${ }^{538}$ O Comitê Conjunto também estará apto a convocar reuniões extraordinárias, sempre que possível, para melhor avaliar as questões que lhe foram submetidas.
} 
solução de controvérsias, neste caso, a arbitragem entre Estados. Desse modo, passa-se à análise deste mecanismo arbitral e suas implicações.

\subsection{SOLUÇÃO DE CONTROVÉRSIAS NOS ACFIs: ARBITRAGEM ENTRE ESTADOS}

A maioria dos tratados de investimento existentes incluem não apenas proteções substantivas sobre investimento, mas também previsões procedimentais para que os investidores possam pleitear diretamente no âmbito internacional a reparação de seus prejuízos diante de violações do Estado receptor de investimentos. Este procedimento normalmente é efetuado através da arbitragem mista investidor-Estado, que foi desenvolvida, principalmente, com o intuito de despolitizar as disputas sobre investimentos, que ora permaneciam restritas ao plano interno dos tribunais domésticos do Estado receptor, muitas vezes enviesados em nome do interesse nacional do último, ora dependiam da proteção diplomática do Estado de origem do investidor, que decidiria de forma discricionária se encamparia ou não a demanda de seu nacional ${ }^{539}$.

Contudo, destaca-se que o acordo de cooperação e facilitação de investimentos brasileiro não segue essa previsão. Primeiramente, estabelece o sistema preventivo de controvérsias e o método de governança institucional, em que mesmo antes de a controvérsia surgir, a estrutura administrativa, por meio dos Pontos Focais ou ombudsman, deverá promover a interlocução entre o governo de um país e os investidores estrangeiros instalados em seu território. Caso a solução negociada não seja alcançada pelos governos em questão, os ACFIs preveem que se passe a uma segunda etapa. Apresentar-se-á uma reclamação do investidor, por meio do governo de seu Estado de origem, ao Comitê Conjunto, que deverá avaliar o caso e, por intermédio de consultas e negociações, buscará solução amigável entre os Estados. Por fim, caso o Comitê Conjunto falhe em resolver a disputa amigavelmente, é disponibilizada a opção da arbitragem entre Estados, em que qualquer das Partes poderá submeter demanda a tribunal arbitral ${ }^{540}$. Ressalta-se aqui que,

${ }^{539}$ REINISCH, August; MALINTOPPI, Loretta. Methods of dispute resolution In: MUCHLINSKI, Peter; ORTINO, Federico; SCHREUER, Christoph. The oxford handbook of international investment law. Oxford: Oxford University Press, p. 691-720, 2008, p.712-713; FRANCK, Susan. Challenges facing investment disputes: reconsidering dispute resolution in international investment agreements In:. SAUVANT, Karl P. (Ed.). Appeals Mechanism in International Investment Disputes Oxford: Oxford University Press, p. 143-192, 2008. p. 149.

${ }^{540}$ HAMILTON, Jonathan; GRANDO, Michelle, White \& Case. Brazil and the Future of Investment Protections. Latin Arbitration Law. Disponível em: <http://www.latinarbitrationlaw.com/brazil-and-thefuture-of-investment-protections/>. Acesso em: 15 set. 2015. UNITED NATIONS CONFERENCE ON 
enquanto nos ACFIs com Angola e Moçambique há apenas uma menção a essa possibilidade - após procedimento obrigatório preventivo de controvérsias -, os ACFIs com México e Colômbia mencionam que uma vez "esgotados" os procedimentos de prevenção, poderá ser acionada a arbitragem internacional, dando esta ênfase ao esgotamento das fases anteriores ${ }^{541}$.

A preferência pela arbitragem entre Estados, pelo menos do ponto de vista do Brasil, decorre de uma resistência histórica à arbitragem de investimentos, conforme já exposto ao se examinar o parecer do Consultor Jurídico do Ministério das Relações Exteriores, Augusto de Rezende Rocha, de 1964, sobre a decisão de aderir ou não ao CIRDI e, também, ao se pormenorizar os debates políticos que pairaram sobre o Congresso quando da tentativa de ratificação dos TBIs brasileiros nos anos 1990, que previam cláusula de resolução de disputas investidor-Estado. Esta oposição se sustentava no fato de que: (i) a arbitragem colocaria os investidores estrangeiros em pé de igualdade aos Estados nacionais, o que seria descabido, pois o Estado soberano detém personalidade jurídica de Direito Internacional, enquanto o investidor possui personalidade jurídica de direito privado interno, constituído no âmbito da ordem jurídica nacional do país de origem ${ }^{542}$; (ii) a arbitragem internacional feriria a soberania brasileira, haja vista que a Constituição não exclui lesão ou ameaça de lesão sobre o território nacional da análise jurisdicional, logo, um acordo em que se estabelece a arbitragem mista não pode tirar do Poder Judiciário brasileiro a apreciação de uma controvérsia surgida em território brasileiro e (iii) a arbitragem investidor-Estado proporcionaria privilégios ao investidor estrangeiro, que estaria em vantagem ao poder de recorrer a instâncias internacionais, em detrimento do investidor nacional que limitaria seu pleito aos tribunais nacionais.

Entretanto, nota-se que no mecanismo dos ACFIs não é o investidor o sujeito apto a reclamar diretamente seus prejuízos perante o tribunal arbitral, porém, "qualquer das Partes”, ou seja, os Estados Partes, que, após análise discricionária de conveniência para se seguir com a controvérsia, decidirão se promoverá seguimento à reclamação já passada por duas fases preventivas, ou se encerrará o procedimento. Esta previsão faz com que se faça

TRADE AND DEVELOPMENT. World investment forum 2014: investing in sustainable development. IIA Conference - 16 October 2014. Daniel Godinho. Disponível em: <http://unctadworldinvestmentforum.org/wp-content/uploads/2014/10/Godinho.pdf>. Acesso em: 16 dez. 2014.

${ }^{541}$ PANZINI, Fabrizio; NEGRI, Constanza. O retorno dos acordos de investimentos na agenda comercial brasileira. Revista Brasileira de Comércio Exterior, ano 29, n. 123, p.58-72, abr./jun. 2015. p. 70.

${ }^{542}$ SOUZA, Renato Rezende de Campos. Cooperation and Facilitation Investment Agreement - CFIA. [apresentação de slides no World Investment Forum]. [s.1.], mai 2015. Disponível em: <http://unctadworldinvestmentforum.org/wp-content/uploads/2015/03/Brazil_side-event-Wednesday_modelagreements.pdf>. Acesso em: 15 set. 2015. 
alusão ao tradicional método da proteção diplomática, ainda operante, contudo, com uso menos frequente após a Segunda Guerra Mundial, haja vista o surgimento da oportunidade de os próprios investidores acessarem diretamente mecanismos de solução de controvérsias para resolver suas disputas contra Estados Anfitriões. Desse modo, por intermédio desse acordo, o investidor de qualquer das Partes volta a depender do juízo político de conveniência do Estado para que se siga com o contencioso e para que tenha seus direitos protegidos.

Debruçando-se sobre o mecanismo de solução de controvérsias presente nos ACFIs, é possível vislumbrar duas vias distintas. A primeira trata-se das disposições atinentes aos acordos africanos, tendo em conta que nos ACFIs com Angola, Moçambique e Malaui deixa-se a cargo do Comitê Conjunto o desenvolvimento dos mecanismos de arbitragem entre Estados $^{543}$. Já a segunda refere-se aos ACFIs com México e Colômbia, pois, embora sua essência seja a mesma ao prever a arbitragem entre Estados, os procedimentos são bem mais detalhados e encontram-se em certa medida no corpo do texto.

Nesse ínterim, passa-se à análise dos ACFIs com México e Colômbia em razão de seu maior detalhamento já existente, ao passo que os mecanismos arbitrais relativos aos acordos com os países africanos ainda não foram desenvolvidos ou publicados por seus Comitês Conjuntos. A cláusula de solução de controvérsias nestes dois ACFIs visa examinar se a medida aventada pela Parte encontra-se mesmo ilegal com o acordo. Esta disposição prevê que a arbitragem poderá ser submetida a um tribunal ad hoc ou, alternativamente, de comum acordo, a controvérsia poderá também ser encaminhada a uma instituição arbitral permanente para a solução de disputas em matéria de investimentos, pelo que tal instituição deverá aplicar o disposto nos acordos, salvo se as Partes decidirem o contrário.

Caso seja constituído tribunal ad hoc específico, este será composto por três árbitros. Cada Parte designará um membro do tribunal arbitral dentro de um prazo não superior a: (i) dois meses posteriores ao recebimento da solicitação de arbitragem, conforme ACFI com o México, e (ii) três meses depois de receber a notificação de

${ }^{543}$ Ademais, segundo Jonathan Hamilton e Michelle Grando, a frase contida nos ACFIs com Moçambique e Malaui "quando julgado conveniente entre as Partes" pode sugerir que os governos do Brasil e de Moçambique ou de Malaui devem concordar em ir à arbitragem, exaltando-se assim, que a arbitragem não é automática, mas depende da concordância expressa das partes. Cf. HAMILTON, Jonathan; GRANDO, Michelle, White \& Case. Brazil and the Future of Investment Protections. Latin Arbitration Law. Disponível em: <http://www.latinarbitrationlaw.com/brazil-and-the-future-ofinvestment-protections/>. Acesso em: 15 set. 2015. 
arbitragem, segundo ACFI com a Colômbia. Esses dois membros deverão instituir um outro árbitro nacional de terceiro Estado, que, após a aprovação das Partes ${ }^{544}$, será nomeado Presidente do tribunal arbitral. O prazo para a nomeação do terceiro árbitro será de dois meses a contar da data de nomeação dos outros dois árbitros membros do tribunal, para o ACFI com o México, e três meses para o ACFI com a Colômbia, a partir da data de nomeação do último deles, pelo que neste acordo, a designação do Presidente deve ser aprovada pelas Partes em um prazo de um mês contado da data de sua nomeação.

Se dentro dos prazos especificados não tiverem sido efetuadas as nomeações necessárias, qualquer das Partes poderá solicitar ao Presidente da Corte Internacional de Justiça (CIJ), em se tratando do ACFI com México, e ao Secretário-Geral da Corte Permanente de Arbitragem (CPA) de Haia, no âmbito do ACFI com a Colômbia, que sejam feitas as designações necessárias. Porém, se o Presidente da CIJ for nacional de uma das Partes ou esteja impedido de exercer a referida função, o Vice-Presidente será convidado a realizar as nomeações, contudo, se mesmo este for nacional de uma das partes ou estiver impedido do exercício das funções, o membro da CIJ de maior antiguidade e que não seja nacional de uma das partes será convidado a constituir os árbitros. De mesmo modo, se o mesmo ocorrer no âmbito da CPA, ou seja, se o Secretário-Geral foi nacional de um dos Estados Partes ou estiver impedido de exercer suas funções, o membro da CPA de maior antiguidade e que não detenha impedimentos ou seja nacional de uma das Partes será convidado para promover as designações necessárias.

Contudo, o ACFI com a Colômbia especifica que também as Partes poderão, por intermédio de compromisso arbitral específico, solicitar o exame da controvérsia que se aventa e, neste caso, o compromisso equivalerá à notificação de arbitragem. Ademais, salienta-se que caso a controvérsia já tenha sido previamente resolvida e estiver coberta pelo manto da coisa julgada, esta não poderá ser trazida à arbitragem por meio do compromisso. Este acordo também deixa claro que uma vez submetida a questão ao Comitê Conjunto, caso descubra-se a existência de outra ação tramitando concomitantemente pelo sistema jurisdicional estatal ou arbitral domésticos, a arbitragem entre Estados somente poderá ser iniciada com a renúncia do investidor à reclamação nos tribunais do Estado Anfitrião, mesmo que já tenha sido iniciada a ação, com vistas a evitar-

${ }^{544} \mathrm{O}$ ACFI com a Colômbia especifica que é requisito que ambas as partes mantenham relações diplomáticas com o Estado do terceiro árbitro e que este tenha experiência reconhecida na área relacionada com a controvérsia. 
se a litispendência, ou seja, duas ações com idênticas partes, causa de pedir e pedido concorrendo em jurisdições distintas ${ }^{545}$.

Quanto aos árbitros, os ACFIs estabelecem que estes devem possuir as seguintes qualidades: (i) ter experiência ou capacidade necessária em Direito Internacional Público e na área de Direito Internacional de Investimentos, o que engloba regras internacionais sobre o tema ou sobre comércio internacional ou resoluções de disputas derivadas de APPRIs $^{546}$; (ii) ter independência, sem que estejam direta ou indiretamente vinculados a qualquer uma das Partes (ou receber instruções das mesmas), árbitros ou testemunhas; (iii) serem cumpridores das Normas de Conduta para aplicação do entendimento relativo às normas e procedimentos que regem a solução de controvérsias da Organização Mundial do Comércio (OMC/DSB/RC/1, de 11 de dezembro de 1996), conforme aplicável à controvérsia, ou outra regra de conduta instituída pelo Comitê Conjunto.

Ademais, o tribunal arbitral determinará o seu próprio procedimento, contudo, segundo o ACFI com a Colômbia, subsidiariamente, será aplicado o Regulamento de Arbitragem da UNCITRAL. Quanto à decisão, o tribunal arbitral decidirá por maioria de votos, sendo a decisão vinculante para ambas as Partes ${ }^{547}$, a qual será proferida no prazo de seis meses após a nomeação do Presidente, salvo acordo em contrário.

Salienta-se que, segundo os ACFIs, o objetivo da arbitragem é recolocar a medida ilegal em conformidade com o acordo, contudo, caso se verifique no laudo arbitral a existência de danos causado e se estabeleça compensação monetária por isso, a Parte que a receber deverá transferi-la aos titulares dos direitos sobre o investimento em apreço, após a

${ }^{545}$ ACFI com a Colômbia, art. 23, $§ 14$, letra "b": "[...] Se um investidor tiver submetido uma reclamação sobre a medida questionada no Comitê Conjunto a tribunais locais ou a um tribunal de arbitragem do Estado Anfitrião, a arbitragem que examine prejuízos somente poderá ser iniciada depois da renúncia do investidor à sua reclamação perante tribunais locais ou tribunal arbitral do Estado Anfitrião. Se, depois de estabelecida a arbitragem, chegar ao conhecimento dos árbitros ou das Partes a existência de reclamações nas cortes locais ou arbitrais sobre a medida questionada, a arbitragem será suspensa". Cf. BRASIL. Acordo e Cooperação e Facilitação de Investimentos entre a República Federativa do Brasil e o Governo da República da Colômbia. Bogotá, 09 de outubro de 2015. Disponível em: $<$ http://www.itamaraty.gov.br/images/ed_atosinter/20151009-ACFI-port2.pdf $>$. Acesso em: 10 out 2015, art. $23, \S 14$, letra "b".

${ }^{546}$ O ACFI com o México acrescenta ainda, em seu art. 19, § 7, letra "a", a necessidade de os árbitros serem pessoas de alto nível moral. Cf. BRASIL. Acordo e Cooperação e Facilitação de Investimentos entre a República Federativa do Brasil e os Estados Unidos do México. Brasília, 26 de maio de 2015. Disponível em: $<$ http://investmentpolicyhub.unctad.org/Download/TreatyFile/3458>. Acesso em: 30 set 2015, art. 19, $\S 7$.

${ }^{547}$ O ACFI com a Colômbia especifica ainda, no art. 23, $§ 11$, que a decisão será respaldada nas disposições do próprio acordo e nos princípios e regras de Direito Internacional aplicáveis. Cf. BRASIL. Acordo e Cooperação e Facilitação de Investimentos entre a República Federativa do Brasil e o Governo da República da Colômbia. Bogotá, 09 de outubro de 2015. Disponível em: $<$ http://www.itamaraty.gov.br/images/ed_atosinter/20151009-ACFI-port2.pdf $>$. Acesso em: 10 out 2015, art. $23, \S 11$. 
dedução dos custos do litígio e em conformidade com os procedimentos internos de cada Parte $^{548}$.

Já no que se refere ao reconhecimento e à execução do laudo arbitral, conforme disposto no ACFI com a Colômbia, no art. 23, § 14, letra “c”, o reconhecimento e execução serão realizados como se se tratasse de sentença judicial transitado em julgado, conforme o estipulado na legislação processual de cada Parte em que se pretenda reconhecer e executar o laudo, em observância aos acordos internacionais sobre a matéria de que seja parte, como por exemplo, a Convenção de Nova Iorque para o Reconhecimento e Execução de Sentença Arbitral Estrangeira, de $1958^{549}$.

Ademais, caberá ao Comitê Conjunto a função de aprovar a regra geral para determinação dos honorários a serem pagos aos árbitros, sendo que as Partes incorrerão em partes iguais nos honorários dos árbitros, assim como nos demais custos do procedimento, salvo acordo em contrário.

O ACFI com a Colômbia prevê ainda algumas ressalvas sobre o objeto da arbitragem e o seu âmbito de aplicação. Neste caso, não poderão ser objeto da arbitragem entre Estados matérias como Responsabilidade Social e Corporativa, Medidas sobre Investimentos e Luta Contra a Corrupção e Disposições sobre Investimentos e Meio Ambiente, Assuntos Trabalhistas, Saúde e Segurança, o que se justifica por envolverem direitos indisponíveis, que não podem ser transigidos, como meio ambiente, direitos trabalhistas, saúde e segurança.

Por fim, o mecanismo arbitral não poderá ser aplicado à controvérsia relativa a fato ocorrido ou a medida adotada antes da entrada em vigor do acordo. Além disso, estabelece-se o prazo prescricional de cinco anos do conhecimento ou de quando se devesse ter conhecimento dos fatos que deram ensejo à controvérsia para que esta possa ser instaurada.

Desse modo, tem-se que a arbitragem entre Estados foi melhor desenvolvida nos acordos com México e Colômbia, o que mostra uma evolução nos próprios acordos

${ }^{548}$ Segundo o art. 23, § 14, letra "d" do ACFI com a Colômbia: "A Parte cujas pretensões forem acolhidas poderá solicitar ao Tribunal Arbitral que ordene a transferência da indenização diretamente aos titulares dos direitos do investimento afetados e o pagamento dos custos a quem os tenha assumido". Cf. BRASIL. Acordo e Cooperação e Facilitação de Investimentos entre a República Federativa do Brasil e o Governo da República da Colômbia. Bogotá, 09 de outubro de 2015. Disponível em: $<$ http://www.itamaraty.gov.br/images/ed_atosinter/20151009-ACFI-port2.pdf $>$. Acesso em: 10 out 2015, art. $23, \S 14$, letra "d".

${ }^{549}$ Ressalta-se que a Convenção de Nova Iorque de 1958 foi promulgada pelo Brasil em 2002. BRASIL. Presidência da República. Casa Civil. Decreto $\mathbf{n}^{\mathbf{0}}$ 4.311, de 23 de julho de 2002. Disponível em: $<$ http://www.planalto.gov.br/ccivil_03/decreto/2002/D4311.htm>. Acesso em: 29 out. 2015. 
brasileiros ${ }^{550}$. Entretanto, a dependência do Estado de origem do investidor para que a demanda siga para o mecanismo jurisdicional internacional ainda se mostra um limitador e uma via dotada de incertezas, visto que não necessariamente o investidor pode ter sua demanda encaminhada às vias arbitrais e, caso não o seja, ele continuará em situação desfavorável e prejudicado, sem qualquer compensação.

\subsection{SOLUÇÃO DE CONTROVÉRSIAS NA COREIA DO SUL}

Até meados da década de 1990, a Coreia do Sul tratava-se de país essencialmente importador de capital, tendo emergido durante o século XX como um dos maiores parceiros comerciais recebedores do fluxo de investimentos estrangeiros diretos do mundo. Salienta-se que, após a Guerra das Coreias (1950-1953), o país dependeu em grande medida dos investimentos estrangeiros para sua reconstrução e desenvolvimento econômico. Nessa esteira, o Estado sul-coreano aderiu aos tratados bilaterais de investimento com o objetivo de criar um ambiente favorável à entrada de investimentos estrangeiros, que emanavam dos principais Estados exportadores de capitais ${ }^{551}$, os quais possuíam em seu arcabouço regulatório estes instrumentos. Os primeiros TBIs sul coreanos firmados remontam à década de 1960 e $1970^{552}$, tendo este processo sido intensificado principalmente a partir dos anos 1990.

De acordo com as estatísticas do Trade Policy Review da Coreia do Sul ${ }^{553}$, elaborado pela OMC, a entrada de investimentos na Coreia aumentou 17\% de 2011 a 2012, contabilizando US\$2,3 bilhões durante o primeiro trimestre de 2012, em comparação ao primeiro trimestre de 2011 - nível mais alto desde 2008. O fluxo de investimentos foi puxado primordialmente por investimentos greenfield concentrados principalmente no setor manufatureiro, os quais são provenientes de regiões industrializadas, como União

${ }^{550}$ PANZINI, Fabrizio; NEGRI, Constanza. O retorno dos acordos de investimentos na agenda comercial brasileira. Revista Brasileira de Comércio Exterior, ano 29, n. 123, p. 58-72, abr.jun 2015. p. 71.

${ }^{551}$ SHIN, Hi-Taek. Republic of Korea In: BROWN, Chester (Ed). Commentaries on selected model investment treaties. Oxford: Oxford University Press, p. 393-424, 2013. p. 393.

552 O primeiro acordo bilateral de investimentos assinado pela Coreia foi em 1964, com a Alemanha. Nos anos 1970, o país prosseguiu em sua política de pactuar tratados de investimento, firmando em 1971 tratado com a Suíça (o qual não se encontra mais em vigor). Seguidamente foram assinados TBIs, em 1974, com União Econômica Bélgica-Luxemburgo (já terminado), em 1974, com a Holanda (já terminado), em 1975, com a Tunísia (em vigor desde 1975), em 1976, com Reino Unido, e em 1977 com a França (em vigor desde 1979), dentre outros que vieram posteriormente. Cf. UNITED NATIONS CONFERENCE ON TRADE AND DEVELOPMENT. Investment Policy Hub. International Investment Agreements Navigator. Korea, Republic of. Disponível em: $<$ http://investmentpolicyhub.unctad.org/IIA/CountryBits/111\#iiaInnerMenu>. Acesso em: 31 out. 2015.

${ }^{553}$ WORLD TRADE ORGANIZATION. Trade Policy Review: Republic of Korea. Geneva, 15 ago. 2012, p. 20. 
Europeia e Japão. Em 2009, a entrada de investimentos estrangeiros na Coreia somou US\$ 9,022 bilhões, em 2011, esse valor representou US\$ 9,773 bilhões, já em 2014, esse valor foi de US\$ 9, 899 bilhões.

Atualmente, o investimento sul-coreano no exterior já é superior ao ingresso de investimento estrangeiro direto no país, fazendo com que a Coreia do Sul seja um grande exportador líquido de capital. Segundo o World Investment Report $2015^{554}$, elaborado pela UNCTAD, a Coreia do Sul é um dos maiores países em desenvolvimento na condição de investidores, tendo emitido, em 2009, investimentos na ordem de US\$ 17, 436 bilhões. Em 2011, essa cifra elevou-se para US\$ 29, 705 bilhões e, em 2014, os investimentos no exterior alcançaram US\$ 30,558 bilhões.

Assim sendo, a política sul-coreana de investimentos possui características tanto de um país importador quanto exportador de investimentos, haja vista que acomoda tanto um fluxo de entrada quanto de saída de capital. No âmbito interno, os investimentos estrangeiros são regidos pela Lei de Promoção de Investimentos Estrangeiros de 1998, de caráter liberal, e que possui como escopo, já em seu art. $1^{\circ}$, o propósito de atrair investimentos estrangeiros e oferecer benefícios de assistência ao investidor ${ }^{555}$. Um dos mais relevantes benefícios criados por esta lei foi a instituição do Ombudsman de investimentos sul-coreano, pelo art. 15-2, já citado anteriormente, responsável pela administração de procedimentos preventivos de solução de controvérsias. Contudo, além do método preventivo, a Coreia do Sul também possui arcabouço jurídico internacional de proteção dos investimentos estrangeiros.

Destaca-se que a primeira onda de TBIs assinados pela Coreia, nos anos 1970, adotava os padrões já existentes dos países europeus com que se firmava acordos, na ordem de promover investimentos europeus em seu território. Já em 1980, os TBIs sulcoreanos focaram-se mais nas nações em desenvolvimento, como Sri Lanka (assinado e em vigor em 1980), Senegal (assinado em 1984 e em vigor desde 1985), Malásia (assinado em 1988 e em vigor desde 1989) e Tailândia (assinado e em vigor desde 1989) e, em 1988, com a iminência do fim da Guerra Fria, o país voltou suas atenções para firmar tratados de investimento com economias em transição, como Hungria (assinado em 1988 e em vigor desde 1989), Polônia (assinado em 1989 e em vigor desde 1990) e Rússia (assinado em

${ }^{554}$ UNITED NATIONS CONFERENCE ON TRADE AND DEVELOPMENT. World Investment Report 2015: Reforming international investment governance. New York and Geneva: United Nations, 2015. p. 8 e p. A4.

${ }^{555}$ COREIA DO SUL. Ato $\mathbf{n}^{\circ} \mathbf{5 5 5 9}$, de 16 de setembro de 1998 . Ato de Promoção do Investimento Estrangeiro. Disponível em: <http://legal.un.org/avl/pdf/ls/Shin_RelDocs.pdf>. Acesso em: 9 nov. 2015. 
1990 e em vigor desde 1991). Destaca-se que, a partir do momento em que iniciou a assinatura de APPRIs com países em desenvolvimento, a Coreia primariamente passou a visar a proteção de seus investidores no exterior, baseando-se formal e substancialmente nos padrões europeus de tratados de investimento ${ }^{556}$.

Nos anos 1990, a Coreia do Sul pactuou acordos de investimento com nações com distintos graus de desenvolvimento, como China (assinado e em vigor em 1992), Vietnã (assinado e em vigor em 1993), Argentina (assinado em 1994 e em vigor desde 1996), Qatar (assinado e em vigor desde 1999), Marrocos (assinado e em vigor desde 2001), Chile (assinado em 1996 e em vigor desde 1999) e México (assinado em 2000 e em vigor desde 2002). Em 2002 foi subscrito acordo de investimentos entre Coreia e Japão (assinado em 2002 e em vigor desde 2003), baseado nos acordos dos EUA, que oferecia tratamento nacional com respeito ao estabelecimento, aquisição e expansão de investimentos por investidores da outra Parte. Mais recentemente, a partir dos anos 2000, a Coreia firmou TBIs com Israel (assinado em 1999 e em vigor desde 2003), Eslováquia (assinado em 2005 e em vigor desde 2006) e Kuwait (assinado em 2004 e em vigor a partir de 2007) ${ }^{557}$.

Ressalta-se que, além dos TBIs firmados, o país também aproveitou a onda de liberalização para aderir a diversos tratados de livre comércio, principalmente após os anos 2000. Nestes, o país toma posicionamento de país exportador de capitais, sendo que os capítulos sobre o investimento dos acordos de livre comércio em que a Coreia faz parte incorporam elementos tanto de liberalização do investimento, quanto de proteção, de modo a criar um ambiente mais estável e transparente para o investidor de qualquer das Partes do acordo $^{558}$. Apesar de adotar política de investimentos bastante liberal, quando se trata de parceiros como Japão, Estados Unidos e União Europeia, o Estado sul-coreano tende a agir como importador de capital, pois estes constituem-se as maiores fontes de investimentos no território sul-coreano. Essa política dual reconhece tanto os potenciais benefícios dos TBIs, quanto dos acordos de livre comércio, criando um clima favorável e atrativo aos investidores estrangeiros ${ }^{559}$.

Em 2003, ao firmar acordo de livre comércio com o Chile, a Coreia do Sul passou a incluir capítulo de investimentos em seus acordos pela primeira vez. Destaca-se que, em

\footnotetext{
${ }^{556}$ SHIN, Hi-Taek. Republic of Korea In: BROWN, Chester (Ed). Commentaries on selected model investment treaties. Oxford: Oxford University Press, p.393-424, 2013. p. 393-398.

${ }^{557}$ Segundo Hi-Taek Shin, a Coreia assinou TBIs com Jamaica (em vigor desde 2007) e Gabão (em vigor desde 2009), contudo, conforme pesquisa, estes não aparecem em vigor no sistema da UNCTAD. SHIN, Hi-Taek. Ibid. p. 397.

${ }^{558}$ WORLD TRADE ORGANIZATION. Trade Policy Review: Republic of Korea. Geneva, 15 ago. 2012, p. 20.

${ }^{559}$ SHIN, Hi-Taek. Op.cit. p.393-424, 2013. p. 393.
} 
2012, a Coreia assinou, juntamente com China e Japão, o Acordo de Livre Comércio Coreia, Japão e China (em vigor desde 2014), acordo de caráter trilateral, com o intuito de melhorar o ambiente de investimento na região, o acordo - primeiro acordo de investimentos que abrange a cooperação econômica trilateral - inclui disposições em matéria de transparência, proteção de direitos de propriedade intelectual e, em especial, elege como mecanismo solução de controvérsias a arbitragem investidor-Estado ${ }^{560}$.

Desse modo, conforme aduz Hi-Taek Shin ${ }^{561}$, pode-se inferir que a promoção e proteção internacional de investimentos sul-coreana tem basicamente duas fontes principais: (i) o TBI sul-coreano de 2001, que é baseado nos tratados que a Coreia havia firmado com países europeus, e que é utilizado para negociar acordos com nações em desenvolvimento; e (ii) o capítulo de investimentos do acordo de livre comércio entre Coreia e EUA, que é influenciado pelas diretrizes do tratado de investimentos norteamericano de 2004.

Como o recorte do presente capítulo se foca na solução e prevenção de disputas, serão abordados, portanto, os mecanismos de solução de controvérsias previstos nestes tratados. No primeiro caso, o TBI coreano dispõe que a solução de disputas deve ser realizada de forma amigável, primeiramente, por intermédio de consultas ou através de meios diplomáticos. Caso o diferendo não seja dirimido, encontram-se disponíveis os remédios locais, ou seja, o judiciário nacional, para solucionar o litígio. Ademais, estipulase em seguida que, caso a controvérsia não seja resolvida em 6 meses (cooling-off period) a partir da data em que o litígio tenha sido levantado por qualquer das partes, a disputa pode ser submetida ao Centro Internacional para Resolução de Disputas sobre Investimentos, e caso o seja, o laudo arbitral proferido por este será final e vinculante ${ }^{562}$.

${ }^{560}$ WORLD TRADE ORGaniZATION. Trade Policy Review: Republic of Korea. Geneva, 15 ago. 2012. p.24.

561 SHIN, Hi-Taek. Republic of Korea In: BROWN, Chester (Ed). Commentaries on selected model investment treaties. Oxford: Oxford University Press, p. 399-400.

${ }^{562}$ Segundo a redação original do art. $8^{\circ}$, do TBI entre Coreia e Panamá (2001): “Article 8 Settlement of Investment Disputes between a Contracting Party and an Investor of the other Contracting Party (1) Any dispute between a Contracting Party and an investor of the other Contracting Party, arising from an alleged breach of an obligation under this Agreement shall, as far as possible, be settled by the parties to the dispute in an amicable way. (2) The local remedies under the laws and regulations of one Contracting Party in the territory of which the investment has been made shall be available for investors of the other Contracting Party on the basis of treatment no less favourable than that accorded to investments of its own investors or investors of any third State, whichever is more favourable to investors. (3) If the dispute cannot be settled within six (6) months from the date on which the dispute has been raised by either party, it shall be submitted upon request of the investor of the other Contracting Party to the International Center for Settlement of Investment Disputes (ICSID) established by the Convention on the Settlement of Investment Disputes between States and Nationals of Other States, opened for signature at Washington on March 18, 1965. (4) The award made by ICSID shall be final and binding on the parties to the dispute. 
Desse modo, observa-se que no TBI sul-coreano há, primeiro, a existência de uma cláusula fork-in-the-road, pelo que apresenta a opção dos tribunais internos como disponíveis à resolução de controvérsias, com respaldo no tratamento nacional e no tratamento da nação mais favorecida, ou seja, sem qualquer discriminação. Há também, caso as partes prefiram, a opção da arbitragem internacional, através do sistema da arbitragem investidor-Estado, pelo que o litígio será resolvido por tribunal $a d h o c^{563}$.

Nesse caso, o TBI não requer que primeiro sejam esgotadas as vias internas, ao invés disso, os remédios locais estarão disponíveis na base do tratamento nacional ou da nação mais favorecida, que são mais favoráveis ao investidor. Mas sim, o que se estabelece é que, caso o demandante prefira acionar o CIRDI, estará, consequentemente, abrindo mão dos direitos de recorrer aos tribunais internos na mesma disputa.

Hi-Taek Shin pontua que a previsão da arbitragem investidor-Estado se dá pelo fato de se reconhecer que os investidores não vislumbram os remédios locais como um método neutro de resolução de disputas, especialmente naqueles casos em que o conflito envolve o Estado receptor de investimentos, devido à sua potencial falta de imparcialidade. Ademais, quanto à linguagem empregada, o TBI entre Coreia e Reino Unido prevê que qualquer disputa legal sobre investimentos no território do Estado Anfitrião será objeto de disputa; previsão bastante ampla e que não limita a base da demanda. Uma versão mais direcionada pode ser vislumbrada no TBI entre Coreia e Kuwait, em que se habilita que o requerente submeta à arbitragem uma controvérsia relacionada a investimento em que tenha ocorrido perda ou dano pelo motivo decorrente de uma alegada violação de um $\mathrm{TBI}^{564}$.

Nas disposições sobre solução de controvérsias presentes nos capítulos sobre investimentos dos acordos de livre comércio, em especial o acordo entre Estados Unidos e Coreia do Sul, destaca-se novamente que, de início, devem ser empreendidas consultas e

Each Contracting Party shall ensure the recognition and enforcement of the award in accordance with its relevant laws and regulations".

${ }^{563}$ Os acordos mais atuais, como o TBI entre Coreia e Japão preveem, ainda, mais uma opção, restando a escolha para solução de controvérsias entre: (i) qualquer previsão previamente acordada para o procedimento de solução de controvérsias; (ii) remédios locais, judiciais ou administrativos; (iii) arbitragem investidor-Estado de acordo com o TBI. Cf. SHIN, Hi-Taek. Republic of Korea In: BROWN, Chester (Ed). Commentaries on selected model investment treaties. Oxford: Oxford University Press, p. 393-424, 2013. p. 414

${ }^{564}$ Ressalta-se que as previsões concernentes ao tipo de cláusula fork-in-the-road, cooling-off period, e à submissão às instituições arbitrais competentes variam de TBI para TBI. Os TBIs mais recentes já preveem não apenas o mecanismo do ICSID, mas também que a arbitragem mista possa ser realizada pelo Mecanismo Complementar do ICSID ou de acordo com as Regras de Arbitragem da UNCITRAL ou qualquer outra instituição arbitral ou outras regras de arbitragem. Cf. SHIN, Hi-Taek. Republic of Korea In: BROWN, Chester (Ed). Commentaries on selected model investment treaties. Oxford: Oxford University Press, p. 393-424, 2013. p. 413-414. 
negociação, o que deve incluir a atuação de uma terceira parte. Caso não haja sucesso na solução através destes meios, pode-se acionar o mecanismo da arbitragem mista. Contudo, um tipo diferente de linguagem é empregado para a submissão à arbitragem de investimentos. A disputa deve ser relacionada à quebra de uma obrigação prevista no capítulo de investimentos, uma autorização para investimentos ou um acordo de investimentos ${ }^{565}$.

Ademais, tanto os TBIs sul-coreanos quanto os acordos de livre comércio com EUA e com o Japão preveem a instalação de um Comitê Conjunto, inspirado no tratado bilateral de investimentos americano e no NAFTA. De acordo com o TBI entre Coreia e Japão, suas funções são: (i) discutir e avaliar a implementação e operação do acordo; (ii) rever as medidas mantidas, emendadas, modificadas ou adotadas em consonância com o art. $5^{\circ}$ do acordo com o propósito de contribuir para a redução ou eliminação de tais medidas; (iii) discutir as medidas adotadas ou mantidas de acordo com o art. $4^{\circ}$ do acordo com o objetivo de encorajar maiores condições favoráveis para os investidores de ambas as Partes; (iv) discutir outros assuntos relacionados a investimentos ${ }^{566}$. Ademais, o Comitê poderá fazer recomendações apropriadas por consenso das Partes e, também, segundo o Acordo de Livre Comércio entre Coreia e Estados Unidos, este poderá interpretar as previsões do acordo, sendo esta declaração vinculante, segundo art. 11:22, $\S 3^{\circ}$ do Acordo. Assim como no TBI dos EUA de 2004, o Acordo de Livre Comércio entre Coreia e Estados Unidos estabelece que a controvérsia pode ser submetida: (i) ao CIRDI sob a égide da Convenção de Washington e as Regras de Arbitragem do CIRDI; (ii) ao Mecanismo Complementar, sob as regras do Mecanismo Complementar; (iii) à arbitragem ad hoc sob

${ }^{565}$ Acordo de Livre Comércio Coreia-EUA, art. 11.16, $\S 1^{\circ}$, letra 1, item (i): “Article1 1.16: Submission of a Claim to ArbitratioN 1. In the event that a disputing party considers that an investment dispute cannot be settled by consultation and negotiation: (a) the claimant, on its own behalf, may submit to arbitration under this Section a claim 11-11. (i) that the respondent has breached (A) an obligation under Section A, (B) an investment authorization, or $(C)$ an investment agreement; [...]". Cf. ACORDO de livre comércio entre Estados Unidos da America e República da Coreia. Chapter Eleven. Investment. Disponível em: $<$ http://investmentpolicyhub.unctad.org/Download/TreatyFile/2542>. Acesso em: 31 out. 2015.

${ }^{566}$ Na redação original: "Article 20 1. The Contracting Parties shall establish a Joint Committee (hereinafter referred to as the "Committee") with a view to accomplishing the objectives of this Agreement. The functions of the Committee shall be:

(a) to discuss and review the implementation and operation of this Agreement;

(b) to review the measures maintained, amended, modified or adopted pursuant to Article 5 of this Agreement for the purpose of contributing to the reduction or elimination of such measures;

(c) to discuss the measures adopted or maintained pursuant to Article 4 of this Agreement for the purpose of encouraging favourable conditions for investors of both Contracting Parties; and

(d) to discuss other investment-related matters concerning this Agreement". ACORDO entre o governo da república da coreia e o governo do Japão para liberalização, promoção e proteção do investimento. Disponível em: <http://investmentpolicyhub.unctad.org/Download/TreatyFile/1727>. Acesso em: 2 nov. 2015. 
as Regras de Arbitragem da UNCITRAL e (iv) qualquer outra instituição arbitral acordada pelas partes sob quaisquer outras regras de arbitragem.

Desse modo, conclui-se que a Coreia do Sul tem evoluído de maneira ímpar nos últimos anos, adquirindo a posição tanto de receptor de investimentos, como de investidor. No plano interno, possui lei específica para a regulação de investimentos estrangeiros, com propósito de promoção e facilitação de investimentos, estipulando a figura do ombudsman de investimentos para que promova a prevenção de controvérsias. Já no âmbito internacional, possui um arcabouço jurídico consoante ao Direito Internacional dos Investimentos, com uma gama de TBIs e Acordos de Livre Comércio assinados.

Analisadas as disposições sobre solução de controvérsias previstas tanto no tratado bilateral de investimentos sul-coreano, quanto no Acordo de Livre Comércio entre Coreia e EUA, verificou-se que a essência das previsões é a mesma, podendo-se afirmar que a opção pela arbitragem mista é uma preferência adotada nas duas espécies de instrumentos jurídicos. O que há de diferente é uma distinção na linguagem empregada, bem como a existência de um leque maior de opções quanto às instituições e regras para a realização da arbitragem mista.

\subsection{SISTEMA DE PREVENÇÃO E SOLUÇÃO DE CONTROVÉRSIAS DOS ACFIs: CRÍTICAS E REFLEXÕES}

Apesar de os sistemas de prevenção e solução de controvérsias presentes nos ACFIs terem sido engendrados com a finalidade de amparar institucionalmente os investidores, ressalta-se que estes possuem algumas características que não colaboram inteiramente para o melhor alcance possível desse objetivo. Dentre elas, destaca-se principalmente a limitação da legitimidade de acesso ao sistema preventivo e jurisdicional de solução de controvérsias, a qual, por não permitir o acesso direto do investidor ao mecanismo arbitral, acarreta também na redução da capacidade de alavancagem das negociações nas fases pré-contenciosas.

Desse modo, nesta seção serão desenvolvidas algumas críticas à sistemática de prevenção e resolução de disputas contidas na estrutura dos acordos brasileiros, destacando com maior ênfase seu caráter avesso à legitimidade procedimental ativa dos investidores e a ausência de alavancagem nas negociações em função da arbitragem entre Estados. 


\subsubsection{Legitimidade na Prevenção e Solução de Controvérsias}

Por todo o exposto, mister reconhecer que os conflitos entre investidores estrangeiros e Estados Anfitriões surgem da contraposição de interesses das Partes, principalmente, quanto à receptividade do investimento estrangeiro em território nacional, às políticas públicas instituídas pelo Estado receptor e, também, aos entraves burocráticos ao investimento estrangeiro, haja vista que os investidores necessitam de permissões, licenças e alvarás para explorarem suas atividades ${ }^{567}$.

Após empreendida análise sobre os sistemas de prevenção e solução de controvérsias dos ACFIs pode-se afirmar que é perceptível que estes instrumentos dão primazia à solução negociada. Esta é observada primeiramente no método preventivo do ombudsman ou ponto focal, em que o investidor levará sua reclamação até o conhecimento de terceiro investido pelo Estado e especialista na área, que administrará as queixas trazidas à baila, dando o pontapé inicial à identificação e exame do que vem maculando ou causando problemas aos investimentos do investidor estrangeiro no território nacional da outra Parte.

Nesta fase, vislumbra-se, portanto, que em havendo conflito ou reclamação, os agentes negociadores consistem no próprio investidor e no Estado receptor de investimentos, ambos interessados diretos em ter a questão resolvida. Durante o desenvolvimento deste processo, o ombudsman interagirá com o investidor estrangeiro e com o Estado (e até mesmo com o ombudsman da outra Parte), como facilitador buscando mitigar essas reclamações, levando em consideração seus interesses e temores. Dessa forma, a raison d'être da política de prevenção instituída nesta fase é reconhecer que os conflitos são inevitáveis, porém, que se faz necessário filtrar certos tipos de conflito (os denominados conflitos frívolos), administrando-os antes que eles evoluam para futuros litígios e, daí em diante, motivado pelo custo econômico do conflito não administrado, o

\footnotetext{
${ }^{567}$ Ademais, segundo Romulo Brillo, o risco de controvérsia na relação com o Estado é consideravelmente maior porquanto esse é formado por um conglomerado de entidades, muitas vezes independentes entre si, no âmbito central, regional e local e, por isso, "uma parte dos órgãos que regulam a atividade econômica não está familiarizada com as obrigações contidas nos acordos e contratos de investimento. Comunicação e coordenação limitadas entre órgãos públicos - e até desentendimentos abertos entre os mesmos - estão com frequência na raiz de diversos conflitos entre investidores estrangeiros e Estados hospedeiros". Cf. BRILLO, Romulo. A prevenção de controvérsias investidor-Estado e alternativas à arbitragem investidorEstado In: RIBEIRO, Marilda Rosado de Sá. Direito Internacional dos Investimentos. Rio de Janeiro: Renovar, 2014. p.271-299.
} 
investidor explore outras alternativas para a resolução do conflito ${ }^{568}$, como por exemplo, a arbitragem entre Estados.

Entende-se que esta abordagem preventiva se encontra em consonância com os preceitos da teoria da negociação com base em interesses, já explicitada no capítulo 4, haja vista que, para resolver a queixa, o enfoque escolhido por este método se baseia claramente na comunicação e interação das partes e na avaliação e consideração dos interesses do investidor, os quais são representados por seus objetivos e preocupações, e que são levados até o ombudsman.

Como tanto o investidor, quanto o Estado receptor tem a intenção comum de evitar que suas relações se deteriorem, partilhando o interesse de promover a atividade econômica por um longo prazo, visa-se através da cooperação a busca por uma solução que detenha o maior nível de satisfação para ambas as Partes ${ }^{569}$. Desse modo, assevera-se que, assim como na teoria citada, caso não se consiga lidar da melhor maneira possível com os interesses trazidos à baila e não se alcance a solução esperada, consequências mais gravosas advirão, como a escalada da queixa em fase posterior para uma futura controvérsia jurisdicional $^{570}$.

No contexto dos acordos de cooperação e facilitação de investimentos, se de fato não se alcançar desenlace neste âmbito institucional, passa-se ainda a um próximo passo, em que a solução negociada sai do nível em que os atores legitimados consistiam no investidor estrangeiro e no Estado receptor de investimentos e evolui para uma nova fase. Nesta, o Estado de origem do investidor perfilha a prerrogativa de apresentar reclamação proveniente de seu nacional ao Comitê Conjunto, instituição intergovernamental composta

${ }^{568}$ BRILLO, Romulo. A prevenção de controvérsias investidor-Estado e alternativas à arbitragem investidorEstado In: RIBEIRO, Marilda Rosado de Sá. Direito Internacional dos Investimentos. Rio de Janeiro: Renovar, 2014. p.271-299. p. 284 e p. 295.

${ }^{569}$ URY, William; BRETT, Jeanne; GOLDBERG, Stephen. Resolução de Conflitos. Lisboa: Actual, 2009. p. 40. Salienta-se, ainda, que conforme assevera Romulo Brillo: "Contudo, é preciso assinalar que não é possível solucionar todas as controvérsias por esse método, que pode sequer ser desejável em certas situações. Onde há assimetrias significativas de poder entre as partes, o juízo baseado em direitos pode ser mais apropriado do que a negociação puramente baseada em interesses. O direito pode pôr partes desiguais em relativo pé de igualdade. Pode haver casos ainda em que os interesses das partes, ou pelo menos de uma delas, sejam mais bem atendidos pela busca por uma vitória total. Tal resultado só pode ser o caso quando uma das partes precisa estabelecer um precedente claro, sem transigir em qualquer medida. Um exemplo seria o de quando um dado Estado hospedeiro busca reafirmar a sua prerrogativa de regular o domínio econômico perseguindo políticas públicas que considera chave”. BRILLO, Romulo. A prevenção de controvérsias investidor-Estado e alternativas à arbitragem investidor-Estado. In: RIBEIRO, Marilda Rosado de Sá. Direito Internacional dos Investimentos. Rio de Janeiro: Renovar, 2014. p. 271299. p. 278.

${ }^{570}$ URY, William; BRETT, Jeanne; GOLDBERG, Stephen. Ibid. p. 40-41. GABBAY, Daniela; FALECK, Diego; TARTUCE, Fernanda. Meios alternativos de solução de conflitos. Rio de Janeiro: FGV, 2013. p. 23- 28. 
pelos representantes de ambos os Estados Partes, que tem por finalidade assessorar as relações entre as Partes, bem como conduzir procedimentos para que se atinja acordo entre as Partes de forma amigável.

Para o presente estudo, faz-se necessário destacar que neste novo domínio, mesmo ainda preponderando a premissa da prevenção, a sistemática de atuação em prol da negociação muda de figura quanto aos agentes legitimados, ao passo que depende de o Estado receber a demanda de seu nacional e analisar se toma para si a queixa e, então, oferecer reclamação perante o órgão institucional responsável, qual seja, o Comitê Conjunto. Nesse ínterim, recebida a reclamação serão empreendidas consultas e negociações entre os Estados, que irão expor de um lado os interesses de seu nacional investidor, e de outro o do próprio Estado Anfitrião. Dessa forma, apesar de a negociação entre Estados ser direta entre as partes legitimadas e também baseada em interesses, nesta esfera prática não é o verdadeiro interessado quem promove a reclamação ou participa da negociação, mas sim seu Estado de origem.

Por fim, passadas as duas fases institucionais preventivas para que o conflito seja dirimido, caso este ainda não tenha sido solucionado, e mais, tendo este evoluído para um litígio, haja vista a insatisfação ter se enrobustecido após diversas tentativas, há adicionalmente uma última fase, agora, no âmbito jurisdicional. De acordo com os ACFIs, a opção escolhida é a arbitragem internacional, entretanto, a preferência das Partes do acordo quando da elaboração da redação deste foi em prol da arbitragem entre Estados. Nesta, apenas os Estados são legitimados a submeter e prosseguir com a controvérsia no mecanismo arbitral internacional e, assim como no instituto da proteção diplomática, dependerá da "capacidade dos investidores de convencer o governo de seu país de origem de que vale a pena dispender recursos financeiros e capital político na defesa de seus interesses" ${ }^{571}$, sendo o acesso da reclamação do investidor ao foro arbitral incerto e improvável ${ }^{572}$.

Faz-se necessário ressaltar que Angola, Moçambique, Malaui, México ${ }^{573}$ e Colômbia possuíam de antemão tratados bilaterais de investimentos com outras nações e que nestes instrumentos internacionais, encontra-se previsto mecanismo arbitral de solução

${ }^{571}$ COSTA, José Augusto Fontoura. Os ACFIs e (a falta de) proteção dos investidores Valor Econômico, Brasília, 30 de jul. 2015. ACFIs e (a falta de) proteção dos investidores. Disponível em: $<$ http://www.valor.com.br/colunistas/Jos\%C3\%A9\%20Fontoura\%20Costa $>$. Acesso em: 6 nov. 2015.

${ }^{572}$ COSTA, José Augusto Fontoura; GABRIEL, Vivian Daniele Rocha. O Brasil, ACFIs e a arbitragem de investimentos. In: Associação Portuguesa de Arbitragem. (Org.). Revista Internacional de Arbitragem e Conciliação. Ano VIII - 2015. 1ed.Lisboa: Almedina, 2015, v. 1, p. 63-82.

${ }^{573} \mathrm{O}$ México, ainda, possui acesso à arbitragem de investimentos em função de ser membro do NAFTA, regido pelo capítulo 11 , em que se prevê a arbitragem mista. 
de controvérsias investidor-Estado, sob os auspícios das regras de arbitragem do CIRDI ou da UNCITRAL. Desse modo, infere-se que a arbitragem de investimento não é instituto tão avesso para esses países assim como o é para o Brasil, como já explicitado anteriormente, e que os países com que o Brasil firmou acordo de investimentos possibilitam em outros tratados que os investidores abarcados por esses tratados com países terceiros acionem diretamente a arbitragem investidor-Estado. No entanto, mesmo assim, no âmbito dos ACFIs preferiu-se adotar a arbitragem Estado-Estado como mecanismo oficial, prevalecendo nesses instrumentos o condicionamento da reclamação à passagem pelo crivo estatal, para que só então se possa acionar o mecanismo arbitral.

Assim sendo, conclui-se que, segundo os parâmetros estabelecidos nos ACFIs, surgindo um conflito entre investidor e Estado, sua forma preliminar de resolução, fundada em mecanismos preventivos, tende a ser caracterizada por um processo negociador baseado em interesses. Entretanto, nas duas fases que envolvem o método preventivo, ombudsman e Comitê Conjunto, repara-se uma distinção nos atores legitimados para o pleito, o que não deixará de afetar seus resultados, haja vista que, no primeiro, o investidor pode recorrer ao ponto focal diretamente apresentando sua queixa, porém, no segundo, o investidor perde legitimidade, tendo de levar a controvérsia ao seu Estado de origem, que decidirá, após analisar sua conveniência, se vale a pena seguir em frente com a reclamação junto ao Comitê ou não. Nesse sentido, a confiança fica depositada exclusivamente nas instâncias políticas estatais internas para que o interesse do investidor seja levado à cabo, o que, dependendo do exame de admissibilidade realizado, pode suprimir esta possibilidade.

Persistindo a disputa, leva-se ainda, em última análise, às discussões baseadas em direitos, ou seja, permite-se o acionamento de mecanismo jurisdicional arbitral entre Estados. Contudo, como o próprio nome indica, a legitimidade é exclusiva dos Estados, excluindo-se novamente o investidor do direito de ação e, restando a ele nova situação de dependência das instâncias governamentais domésticas para que sua demanda seja resolvida por tribunal arbitral.

Portanto, assevera-se que as normas e instituições criadas nos ACFIs não admitem legitimidade ativa e passiva aos investidores em todas as etapas do sistema de prevenção e solução de controvérsias, apenas na fase de acionamento do ombudsman, deixando nas outras fases o investidor à mercê de seu Estado de origem. Isto causa estranhamento, ao passo que mesmo em se tratando de prevenção, contudo, não se envolve uma das partes afetadas. Ainda, destaca-se o fato de que essa dependência do Estado vulnera o investidor e o sujeita a possíveis "abusos estatais, os quais podem decorrer de fragilidades 
institucionais e instabilidade política" ${ }^{, 574}$, não havendo certeza ou previsibilidade se a sua controvérsia será realmente encampada e levada adiante para ser resolvida.

\subsubsection{A Aplicação da Teoria da Sombra do Direito na Solução e Prevenção de Controvérsias dos ACFIs}

Para que a negociação com base em interesses seja alcançada na fase preventiva de solução de controvérsias faz-se necessário que as partes se encontrem estimuladas para empreender esforços na promoção de propostas e contrapropostas e, assim, chegarem a um acordo que seja minimamente satisfatório a ambos os lados. No entanto, trazendo-se à baila a teoria da sombra do direito, explanada no capítulo 4, aplicada inicialmente no direito de família americano e, depois, transbordando para outras áreas do direito em razão de seus preceitos fundamentais aplicados para explicar o comportamento dos atores em uma negociação, observa-se que esta incitação à negociação decorre também da determinação de um sistema de solução de controvérsias adequado e que favoreça alavancagem ao investidor.

No âmbito do Direito dos Investimentos, as reais motivações para que os investidores e os Estados receptores alcancem soluções negociadas repousam na premissa de evitar a demora e os altos custos que as partes irão enfrentar se instaurados os procedimentos arbitrais; de evitar os riscos e as incertezas da litigância atinentes a todo processo; de preservar as relações entre investidor e Estado, que normalmente compartilham do interesses comuns de promover a atividade econômica em discussão por um longo prazo, e da pretensão de que a solução negociada seja mais efetiva que a imposta por um tribunal arbitral, visto que englobaria as preferências de cada parte, as quais foram aceitas pela outra parte no momento da negociação.

Ocorre que, além dessas motivações, para negociar, tanto o investidor, quanto o Estado receptor de investimentos necessitam também conhecer o direito aplicável e ter um mínimo grau de previsibilidade com relação ao resultado do conflito, caso este evolua para um litígio e seja encaminhado ao mecanismo jurisdicional ${ }^{575}$. Ter uma margem de previsibilidade do possível resultado da disputa em que se sabe da aplicação de

${ }^{574}$ COSTA, José Augusto Fontoura; GABRIEL, Vivian Daniele Rocha. O Brasil, ACFIs e a arbitragem de investimentos. In: Associação Portuguesa de Arbitragem. (Org.). Revista Internacional de Arbitragem e Conciliação. Ano VIII - 2015. 1ed.Lisboa: Almedina, 2015, v. 1, p. 63-82.

${ }^{575}$ BRILLO, Romulo. A prevenção de controvérsias investidor-Estado e alternativas à arbitragem investidorEstado In: RIBEIRO, Marilda Rosado de Sá. Direito Internacional dos Investimentos. Rio de Janeiro: Renovar, 2014. p. 271-299 p. 289. 
determinadas regras jurídicas se torna importante ao passo que, dessa maneira, se tem alguma estimativa do impacto que essa decisão terá sobre as partes. Nesse ínterim, estando tanto o investidor quanto o Estado cientes do que a sombra do direito projetará em uma estimativa de futuro, é possível delimitar o espaço de negociação das partes.

O sistema de prevenção e solução de controvérsias propugnado pelos ACFIs é oficialmente inspirado no aparato de solução de controvérsias desenvolvido pela Coreia do $\mathrm{Sul}^{576}$. Neste último, havendo uma controvérsia sobre investimentos, os investidores estrangeiros são aptos a enviá-la diretamente à agência responsável, no caso, a KOTRA, que atua no âmbito do escritório do ombudsman de investimentos sul-coreano. Encaminhada a demanda, a Investment Aftercare Division designará os Home Doctors responsáveis, espécie de consultores executivos vinculados à instituição, que irão recebêla, analisá-la e administrá-la, mantendo o investidor informado de cada passo tomado para a resolução do conflito. Assim sendo, esta estrutura atua de modo preventivo na recepção de queixas dos investidores, conciliando os interesses do investidor e do Estado receptor na busca de uma solução concreta, com a intenção primordial de prevenir um problema antes que este se enrobusteça.

Nos últimos anos, o serviço de resolução de conflitos efetuado no âmbito do ombudsman sul-coreano tem se mostrado bastante satisfatório. Segundo relatório oficial do governo da Coreia do Sul, intitulado Foreign Investment Ombudsman Annual Report $2014^{577}$, de 2005 a 2014 foram submetidos 3.748 casos ao ombudsman. Só em 2005, este número chegou ao montante de 351 casos, tendo se elevado em 2010 para 385 casos, e se mantido estável em 2013, com 383 casos para, finalmente, alcançar o seu maior patamar em 2014, com 437 casos. Dentre os serviços prestados e registrados pelo relatório estão o melhoramento do sistema, que se refere à reforma regulatória e/ou a mudança de leis; a intervenção administrativa, que se trata dos passos tomados para fazer melhorias em um quadro legal já existente e a resolução das queixas pelos Home Doctors, que consiste nos problemas resolvidos internamente por estes agentes, frequentemente através de consultas.

Quanto à prestação de serviços de resolução de conflitos trazidos por investidores, de 2005 a 2014 foram resolvidas 2.866 controvérsias, sendo que, em 2005 estas somavam

${ }^{576}$ COREIA DO SUL. Foreign Investment Ombudsman Annual Report 2014. 2015. p.66-67. p.15 Disponível $<$ http://125.131.31.47/Solars7DMME/004/15Foreign_Investment_Ombudsman_Annual_Report2014.pdf >. Acesso em: 5 nov. 2015.

${ }^{577}$ COREIA DO SUL. Foreign Investment Ombudsman Annual Report 2014. 2015. p. 42. Disponível em: $<$ http://125.131.31.47/Solars7DMME/004/15Foreign_Investment_Ombudsman_Annual_Report2014.pdf >. Acesso em: 5 nov. 2015. 
264 casos solucionados; em 2010 este número se elevou para 335 casos; em 2013, este montante decresceu para 238 casos e, em 2014, registrou-se 316 controvérsias dirimidas. Esses dados podem ser melhor observados no seguinte gráfico:

\section{Gráfico 4 - Controvérsias Resolvidas pelo Sistema Home Doctors}

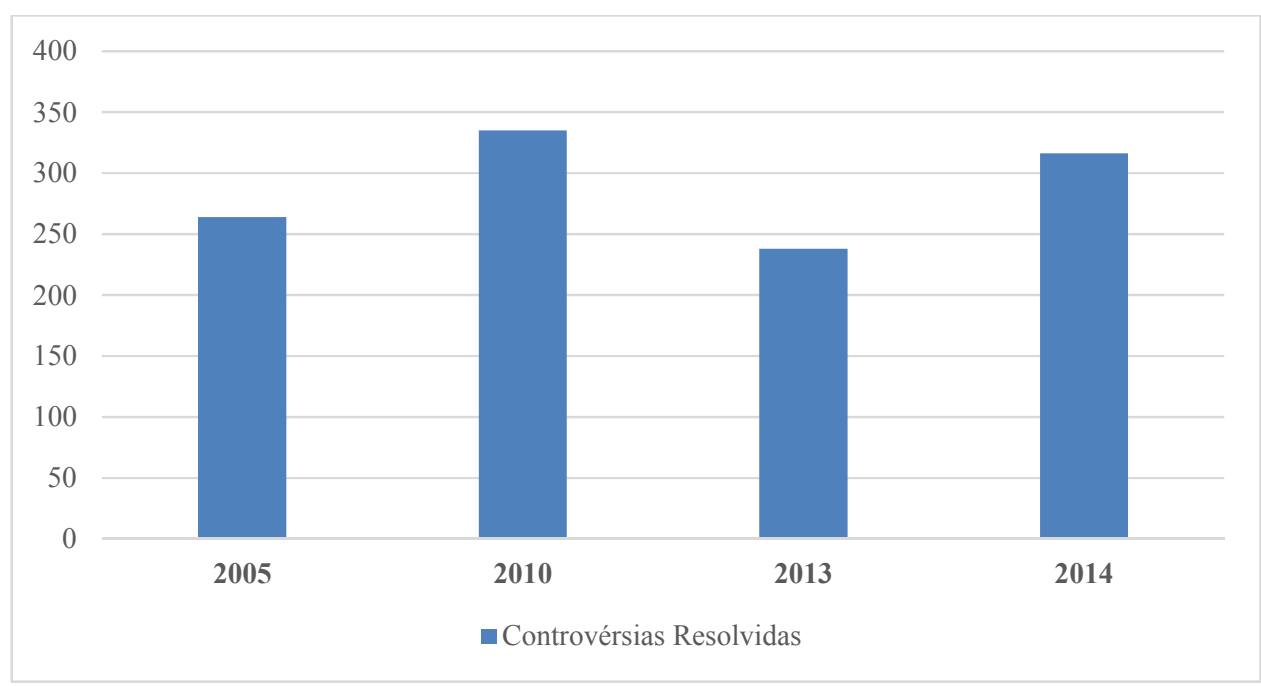

Fonte: Coreia do Sul, $2014^{578}$.

Entretanto, o arcabouço jurídico sul-coreano na proteção e solução de investimentos estrangeiros não envolve apenas a instância preventiva do ombudsman. Caso a queixa do investidor não seja resolvida nesta esfera institucional e evolua para um litígio, pode-se recorrer às vias jurisdicionais tanto nacionais quanto internacionais. No plano internacional, ressalta-se que a Coreia do Sul possui extensa gama de tratados bilaterais de investimentos firmados com os mais diversos países e, neles, está contida cláusula de solução de controvérsias, que elege a arbitragem investidor-Estado como mecanismo apropriado de resolução ${ }^{579}$. Ou seja, caso a controvérsia não seja resolvida de antemão pelo ombudsman, o investidor poderá acionar tribunal arbitral e demandar diretamente o Estado receptor através da arbitragem mista ${ }^{580}$.

${ }^{578}$ COREIA DO SUL. Foreign Investment Ombudsman Annual Report 2014. 2015. p. 42. Disponível em:

$<$ http://125.131.31.47/Solars7DMME/004/15Foreign_Investment_Ombudsman_Annual_Report2014.pdf >. Acesso em: 5 nov. 2015.

${ }^{579}$ Nota-se que as regras de arbitragem e a submissão institucional na arbitragem de investimentos prevista nos TBIs sul-coreanos varia entre o CIRDI e a UNCITRAL e seus respectivos regulamentos de arbitragem.

${ }^{580}$ De acordo com pesquisa efetuada no sítio eletrônico do CIRDI, observa-se que até então, existem apenas 2 arbitragens de investimento acionadas por investidores sul-coreanos sob os auspícios do Centro, quais sejam os casos Samsung Engineering Co., Ltd. v. Sultanate of Oman, ICSID Case No. ARB/15/30 e 
Nota-se, portanto, após a análise dos dados expostos, que o sistema preventivo de solução de controvérsias da Coreia do Sul tem alcançado sucesso, ao passo que, de 2005 a 2014, 2.866 controvérsias foram resolvidas por intermédio do Home Doctor, e caso estas não tivessem sido dirimidas no âmbito do aparato institucional do ombudsman e de seus funcionários, estas possivelmente teriam evoluído para litígios e seriam encaminhadas à arbitragem investidor-Estado para que se alcançasse uma resolução efetiva.

Nesse diapasão, para explicar o comportamento das partes nesta negociação, trazse à baila a contextualização da teoria da sombra do direito ao caso sul-coreano. No caso do método da Coreia do Sul, prevê-se, em um primeiro momento, a possibilidade de resolução negociada por meio da composição dos interesses das partes, ou seja, há uma negociação baseada em interesses, que é realizada por intermédio do ombudsman. Entretanto, caso esta resulte infrutífera, a outra parte, ou seja, o Estado receptor, terá ciência de que o conflito certamente evoluirá para o mecanismo arbitral, haja vista que o investidor é habilitado a efetuar a própria reclamação, sem depender do consentimento de seu Estado de origem, e assim o fará se ainda se sentir prejudicado.

Se a sombra do direito é bem projetada, existirá uma estimativa das partes quanto aos possíveis resultados condenatórios que cada uma irá auferir quando do prosseguimento da arbitragem e da prolação do laudo arbitral, o que consequentemente implicará no pagamento de compensações para a parte vitoriosa, além dos custos com taxas e honorários frente à possibilidade desse futuro resultado. Nesse sentido, havendo um mínimo de previsibilidade sobre o resultado, conforme as partes vislumbrem quais serão seus possíveis prejuízos por uma decisão arbitral e em que temos o serão, isto alargará o espaço de negociação e aumentará a capacidade dos investidores de alavancarem estas negociações. Haverá então um incentivo maior para o cumprimento das normas dos acordos internacionais, as partes estimarão quais termos poderão ser melhor negociados e tentarão alcançar uma saída que seja mais satisfatória do que aquela calculada caso o litígio prossiga para a arbitragem. Este empenho se mostra até mesmo no sentido de preservar as relações econômicas entre as partes no futuro, ao invés de encararem um resultado que seja

Ansung Housing Co., Ltd. v. People's Republic of China, ICSID Case No. ARB/14/25, ambos pendentes. Enquanto isso, a Coreia do Sul foi demandada no CIRDI somente 3 vezes, nos casos Hanocal Holding B.V. and IPIC International B.V. v. Republic of Korea, ICSID Case No. ARB/15/17 (pendente); LSFKEB Holdings SCA and others v. Republic of Korea, ICSID Case No. ARB/12/37 (pendent) e Colt Industries Operating Corporation v. Republic of Korea, ICSID Case No. ARB/84/2, em que foi atingido acordo entre as partes e a demanda descontinuada. Ressalta-se que, optou-se por realizar este levantamento no CIRDI em razão de ser o mecanismo de solução de controvérsias investidor-Estado mais popular, o que não faz com que o dado seja absoluto, visto que não afasta a possibilidade de haverem mais arbitragens no âmbito de outras regras ou centros, como por exemplo sob a égide da UNCITRAL. 
comparativamente menos benéfico. Assim sendo, o resultado que o direito imporá, caso não haja acordo, dá a cada uma das partes uma espécie de moeda de troca, e estando as partes cientes disso, estas empreenderão esforços para utilizá-las no melhoramento das negociações.

Dessa forma, o fato de a Coreia do Sul possuir o mecanismo de solução de controvérsias investidor-Estado também contribui para o sucesso em seu método preventivo de solução de controvérsias e no elevado número de soluções negociadas obtidas nos períodos analisados, pois, assim, aumenta-se a capacidade dos investidores alavancarem as negociações, promovendo maior espaço para que as controvérsias sejam resolvidas por acordos mutuamente satisfatórios.

Ocorre que, apesar de o Brasil ter se inspirado neste modelo e ele ser bemsucedido, este foi adaptado apenas parcialmente, prejudicando o alcance de uma solução negociada. O Brasil optou por instituir em seu arcabouço institucional a figura do ombudsman, contudo, foi também estabelecido o mecanismo de arbitragem internacional entre Estados. Nesta sistemática, as partes poderão empreender negociações nas fases preventivas, normalmente, no entanto, não há estímulo para uma solução negociada, pelo fato de, em primeiro lugar, não haver perspectiva de o investidor acionar o mecanismo arbitral, quando do insucesso das negociações, e, em segundo lugar, de os Estados não possuírem estímulo para prosseguir com a demanda, a não ser que o investidor o convença disso, haja vista que além de a demanda não ser propriamente deste, a evolução para a esfera jurisdicional também remonta a desgastes políticos e financeiros indesejados aos entes soberanos.

Logo, o fato de haver uma relação de dependência do Estado de origem para o acionamento do mecanismo arbitral contribui para que a sombra do direito seja fraca, pois sem haver previsibilidade de um possível resultado na arbitragem entre Estados, as partes não conseguirão identificar os termos que poderiam utilizar como moeda de troca e não haverá pressão para que estas se empenhem no alcance de um resultado mais benéfico que o que seria caso se prosseguisse para a solução jurisdicional, bem como também não haverá pressão para que o Estado Anfitrião se esforce nas negociações, pois caso esta não seja alcançada, não há certeza sobre o prosseguimento da demanda.

Assim sendo, conclui-se que o sistema de solução de controvérsias previsto nos ACFIs, por possuir a peculiaridade da arbitragem entre Estados é limitado e inibe a 
capacidade de os investidores negociarem à luz da lei ${ }^{581}$ e alavancarem as negociações na etapa anterior à fase jurisdicional. Diferentemente do sistema da Coreia do Sul, em que o investidor pode acessar diretamente a arbitragem de investimentos caso continue se sentindo prejudicado, o que acarreta previsibilidade do resultado futuro e pressão necessária para que as partes estruturem um acordo que seja mais benéfico que o resultado estimado, na esfera dos ACFIs, mesmo que se tente aferir o resultado da arbitragem Estado-Estado, a sombra do direito projetada é fraca e cheia de incertezas, pois primeiro se depende de o Estado de origem ser convencido a encampar o litígio e acionar a arbitragem, logo, há maior dificuldade em termos de previsibilidade de resultados.

Portanto, como o investidor e o Estado receptor, no âmbito do acordo brasileiro, não têm como prever se o Estado de origem do investidor tomaria para si a controvérsia e prosseguiria à arbitragem, nem quais são as garantias do resultado da solução arbitral, as duas partes negociadoras atuarão sem pressão suficiente. Isso faz com que não se aumente a capacidade ou esforço para alavancarem as negociações, principalmente no que se refere ao Estado receptor de investimentos, que caso não firme acordo com o investidor, poderá, até mesmo, permanecer nas mesmas circunstâncias em que se encontra, ou seja, violando obrigações e direitos previstos no acordo de investimentos, o que faz com que persista quadro prejudicial ao investidor.

\subsubsection{A Falta de Coordenação Institucional entre os Mecanismos}

Outros fatores que, segundo Romulo Brillo ${ }^{582}$, explicam o motivo de um número elevado de conflitos entre investidores e Estados não terem sido administrados de modo eficaz, evoluindo para a condição de litígios, são a falta de comunicação e coordenação entre as instituições. Nesse sentido, ao analisar os ACFIs brasileiros, evidencia-se novamente que, o aparato institucional que cuida da etapa preventiva são os pontos focais ou ombudsman e o Comitê Conjunto, em que o investidor se encontra legitimado apenas para acessar diretamente o Ponto Focal, enquanto no Comitê Conjunto são aptos a acionálo apenas os Estados.

\footnotetext{
${ }^{581}$ BRILLO, Romulo. A prevenção de controvérsias investidor-Estado e alternativas à arbitragem investidorEstado In: RIBEIRO, Marilda Rosado de Sá. Direito Internacional dos Investimentos. Rio de Janeiro: Renovar, 2014. p. 271-299. p. 289.

582 BRILLO, Romulo. A prevenção de controvérsias investidor-Estado e alternativas à arbitragem investidorEstado In: RIBEIRO, Marilda Rosado de Sá. Direito Internacional dos Investimentos. Rio de Janeiro: Renovar, p.271-299, 2014. p. 284.
} 
Ocorre que no plano dos ACFIs, a ausência de coordenação pode ser observada pelo fato de que nem o investidor poderá levar reclamações ao Comitê Conjunto, nem o ombudsman ou ponto focal, que já havia administrado anteriormente a questão, poderá levar a queixa invocada pelo investidor a este órgão institucional. A primeira hipótese já foi discutida, concerne à ausência de direitos subjetivos aos investidores, haja vista a legitimidade de acesso ser restrita apenas aos Estados, contudo, na segunda, seria no mínimo plausível, em função da economia processual e, também em alusão à premissa da cooperação, que o ponto focal encaminhasse as reclamações que não alcançaram sucesso em sua esfera para a próxima etapa, até mesmo como forma de prosseguir sua função precípua de continuar auxiliando o investidor.

Isto seria benéfico ao passo que a reclamação direta efetuada pelo investidor, no âmbito do ombudsman, seria apenas encaminhada por este ao Comitê Conjunto. Ressaltase que o ponto focal designado, além de se tratar de um organismo dotado de especialistas e grandes conhecedores da matéria de investimentos e de comércio internacional (da parte brasileira, a CAMEX), acompanhou todo o processo inicial para a solução da controvérsia, tendo o condão de avaliar se a disputa encaminhada se trata ou não de controvérsia frívola, e se esta merece prosseguimento ao Comitê Conjunto.

Ademais, este encaminhamento conteria a reclamação original realizada pelo investidor, com todos os seus pleitos e consternações, contudo, considerando o procedimento de acesso ao Comitê, quando da reclamação feita pelo Estado, não se sabe se esta seria exatamente igual ou melhor elaborada, deixando alguma margem de incerteza. Por fim, também seriam enviadas todas as provas e outras evidências já levantadas nesta etapa para o Comitê Conjunto, o que caracterizaria uma comunicação institucional entre os órgãos em prol da cooperação.

Assim sendo, além de restringir o acesso do particular às negociações, essa sistemática faz com que a comunicação do real interessado com a outra parte, ou seja, o Estado receptor, torne-se mais difícil, pois dependerá da interlocução do Estado de origem do investidor para isso. Além disso, o propugnado nos ACFIs também limita a articulação e cooperação institucional entre seus dois institutos de governança, responsáveis pela mitigação das controvérsias existentes, o ombudsman e o Comitê Conjunto, haja vista que não prevê a possibilidade de encaminhamento da ação ao Comitê pelo ombudsman, o que seria benéfico ao passo que direcionaria a reclamação original e feita pelo investidor ao Comitê, bem como articular-se-iam informações entre os órgãos para a melhor compreensão da queixa, tudo isso corroborando para uma melhor articulação institucional. 


\subsection{CONSIDERAÇÕES FINAIS}

Após empreendida análise sobre os mecanismos de prevenção e solução de controvérsias dos acordos de cooperação e facilitação de investimentos, pode-se afirmar que, seguindo a linha de acordos de investimentos mais recentes, a prevenção de controvérsias prevista nos ACFIs, baseadas no Comitê Conjunto e nos Pontos Focais ou Ombudsman, trata-se de uma das inovações mais benéficas do acordo, contudo, com ressalvas.

Esses mecanismos têm como principal premissa o alcance de uma solução negociada, de modo que se consiga resolver a reclamação ainda nas instâncias preventivas, para que se evite o prolongamento da controvérsia até a fase arbitral. Nesse sentido, o fato de o investidor poder levar diretamente e de modo facilitado sua queixa ao ombudsman se mostra favorável, visto que esta instituição terá o condão de mitigar os conflitos que se aventam, promovendo para isso a interação tanto com entidades privadas, quanto com autoridades governamentais. Assim, o fato de haver um canal de comunicação aberto para o investidor, bem como organismo designado exclusivamente para dar-lhe suporte e resolver seus problemas, inclusive promovendo a interação com a outra parte, faz com que se espere que este seja utilizado da melhor forma possível para a prevenção de litígios.

A ideia por trás do Comitê Conjunto também se mostra interessante, ao passo que se cria uma estrutura fixa focada na implementação e operacionalização do acordo, além de atuar também na prevenção de controvérsias (e, quando aplicável, na implementação das regras da solução arbitral entre Estados). Contudo, neste âmbito, apenas o Estado será o agente legitimado para levar a reclamação ao Comitê. Mesmo que na reunião bilateral seja possível a presença de representante do investidor, a queixa deste somente será submetida ao órgão após avaliação e determinação do Estado, restando o investidor à sua mercê.

No entanto, mesmo havendo o sistema preventivo e que ele tenha se mostrado satisfatório na prática em outros tratados, o próprio sistema de solução de controvérsias estruturado já inibe que negociações na fase pré-contenciosa sejam mais pujantes e que atendam o real interesse das partes. Essa condição pode ser explicada através da teoria da sombra do direito, que apesar de ter sido desenvolvida em outra seara do direito, já tem sido utilizada em outras áreas, e pode também ser aplicada ao caso em tela.

No contexto dos ACFIs, a teoria da sombra do direito faz com que se perceba que, sem a previsibilidade de que o investidor poderá recorrer à arbitragem de investimentos no 
futuro e qual será esse resultado, baseado no direito aplicável conhecido pelas partes, investidor e Estado receptor não terão alavancagem para empreender mais esforços para uma solução negociada, haja vista que se nenhum acordo for alcançado, ainda paira a dúvida se o Estado, legitimado para a outra fase preventiva e para a fase postulatória na arbitragem, irá proceder com a reclamação. Essa situação de dependência, regida pela incerteza e imprevisibilidade da vontade Estatal, faz com que se volte no tempo, aos episódios em que se predominava a proteção diplomática e os investidores nada podiam fazer, senão tentar convencer seu Estado de que mereciam ter seu direito reclamado e sua compensação pela violação paga.

Dessa forma, o que se nota com esse sistema de solução de controvérsias é que, apesar de esforços para o estabelecimento de um arcabouço institucional que atenda o investidor, há uma desproteção processual do mesmo e uma falha no ambiente institucional da negociação, tendendo para uma falta de alavancagem da capacidade das partes em negociarem e, caso esta realmente não seja alcançada, em uma situação de desamparo. 


\section{CONCLUSÃO}

De todo exposto, vislumbra-se que o Direito Internacional dos Investimentos Estrangeiros, atualmente, tem passado por uma mudança em seu arcabouço regulatório, e o Brasil inclui-se ativamente nesse contexto. Além de novas iniciativas que finalmente se aproximam da concretude, como os mega acordos, consubstanciados na Parceria Transpacífica (Trans-Pacific Partnership - TPP) e na Parceria Transatlântica de Comércio e Investimento (Transatlantic Trade and Investment Partnership - TTIP), que possuem capítulos sobre investimentos, há também iniciativas pontuais de alguns países na atualização, mudança ou, até mesmo, na criação de novos padrões regulatórios de promoção e proteção de investimentos.

A preocupação com a regulamentação internacional dos investimentos não é recente, como se pôde notar no segundo capítulo, tendo raízes que remontam ao século XVII, com os Tratados de Amizade, Comércio e Navegação e ao século XIX, com o regime de capitulações, instrumentos pioneiros que tentavam garantir alguns direitos aos nacionais dos Estados envolvidos que investissem na outra Parte. Contudo, a prática mais frequente de proteção até a primeira metade do século XX era a proteção diplomática, em que o Estado de origem do investidor, decidido a encampar sua reclamação, levava esta adiante perante os foros internacionais.

No entanto, o regime internacional dos investimentos veio a florescer com mais intensidade após a Segunda Guerra Mundial, em que, passados os insucessos para se instituir um marco multilateral que regesse o tema, como por exemplo, por meio da Carta de Havana, do Projeto de Código Internacional para o Tratamento Justo do Investimento Estrangeiro e do Projeto Ab-Shawcross, a matéria passou a ser normatizada pelos acordos de promoção e proteção de investimentos, e mais intensamente pelos tratados bilaterais de investimentos.

A proliferação desses instrumentos não foi imediata, tendo se intensificado apenas a partir dos anos 1980 e 1990, quando da liberalização econômica e financeira e da expansão dos investimentos estrangeiros por todo o mundo. Países em desenvolvimento, que antes se mostravam reticentes a estes instrumentos, principalmente nos anos 1960 e 1970, no âmbito das discussões sobre a soberania permanente dos recursos naturais e da 
Nova Ordem Econômica Internacional, demonstradas no capítulo 2, passaram a aderir aos APPRIs com o intuito de atrair capital para o fomento de seu desenvolvimento econômico.

Esses instrumentos foram criados com o escopo de prover maior proteção aos investidores em território alienígena contra ações soberanas dos Estados receptores que pudessem afetar seus investimentos de forma negativa, como expropriações sem a devida compensação, interferência na livre remessa de capitais ou qualquer tipo de tratamento discriminatório. O padrão de tratamento insculpido tradicionalmente nos tratados abrange uma diversidade de cláusulas, dentre as quais se destacam as de definição de investimento e investidor, de admissão e estabelecimento, de padrões de tratamento (nacional, nação mais favorecida e justo e equitativo), de expropriação, de compensação, de transferência de fundos e de resolução de conflitos.

Quanto às previsões acerca da instauração de um mecanismo de solução de controvérsias, traz-se à baila outro sustentáculo do Direito Internacional dos Investimentos, qual seja a arbitragem investidor-Estado. Esta é caracterizada pela doutrina como uma grande evolução, haja vista que possibilita ao investidor estrangeiro, ou seja, ao particular, o acesso direito à arbitragem internacional para resolver seus litígios contra violações dos Estados receptores, sem a necessidade de se envolver o Estado de origem do nacional investidor na relação, assim como ocorria na proteção diplomática.

Nesse ínterim, a principal instituição voltada à resolução de conflitos sobre investimentos é o Centro Internacional para Resolução de Disputas sobre Investimentos, estabelecido em 1966, sob o respaldo jurídico da Convenção de Washington de 1965. Como organismo independente e despolitizado, este provém regras e mecanismos para a resolução de disputas sobre investimentos por meio dos métodos de conciliação, arbitragem e fact-finding, fornecendo também listas de árbitros e um aparato administrativo para a condução desses procedimentos. Destaca-se que, a priori, apenas os membros CIRDI têm acesso ao Centro, contudo, esta sistemática também pode ser estendida a países não membros por meio do Mecanismo Complementar do CIRDI, que amplia a possibilidade de acesso ao Centro. Entretanto, apesar de a proporção ser bem menor que comparado ao CIRDI, há também de se destacar a atividade de outros mecanismos arbitrais na resolução de controvérsias sobre investimentos, como é o caso das arbitragens sob os auspícios das regras da UNCITRAL e das arbitragens administradas pela Câmara de Comércio Internacional e pela Câmara de Comércio de Estocolmo, cada qual com suas próprias regras e procedimentos. 
Constatou-se que o Brasil foi resistente ao regime regulatório e à arbitragem de investimentos desde a sua gênese, alegando, principalmente, que esta última violaria a soberania estatal e colocaria o Estado em condição de igualdade com os particulares, além de sub-rogar funções públicas essenciais, como as judiciais, a tribunais arbitrais internacionais. São argumentos que já não convencem. Aliás, na década de 1990 vislumbrou-se um lampejo de mudança, quando da assinatura pelo Brasil de 14 tratados bilaterais de investimento, todos com cláusulas de resolução de disputas investidor-Estado. Estes instrumentos foram alvo de várias críticas dos congressistas brasileiros, motivo pelo qual não foram ratificados, tendo sido tirados de pauta ao final do governo Fernando Henrique Cardoso. Dentre as críticas mais pungentes estavam as de que: (i) os TBIs poderiam limitar a capacidade do Estado de regulação estatal; (ii) havia problemas com a constitucionalidade dos textos dos TBIs no que tange à compensação por expropriação, com a ausência de possibilidade de indenização por títulos da dívida pública - instituto previsto no direito brasileiro para os casos de desapropriação de imóveis urbanos e rurais para fins de reforma agrária -; (iii) ausência de exceções quanto à livre transferência de capital, quando da ocorrência de graves crises financeiras ou desequilíbrios na balança de pagamentos e, novamente, (iv) sobre o mecanismo de solução de controvérsias, com base nos argumentos de afastamento da competência do judiciário brasileiro, ante ao descumprimento do esgotamento dos recursos internos antes de se acionar a arbitragem internacional e do afastamento da apreciação do judiciário de lesão ou ameaça de lesão e, por fim, a condição de o Estado restar no mesmo patamar que o particular perante o tribunal arbitral.

Pouco mais tarde, nos anos 2000, percebeu-se uma transição da condição do Brasil de apenas grande receptor de investimentos, que ainda o é, para também investidor. Atento a isso, o governo brasileiro instaurou um grupo de trabalho intergovernamental, em conjunto com a iniciativa privada - representada pela CNI e pela FIESP - para identificar os principais pontos de consternação dos investidores brasileiros no exterior, bem como estruturar um novo acordo de investimentos para o país que melhor os protegessem. Assim, fica evidente que a visão de que o Brasil deveria permanecer ao largo dos acordos de investimento ficara para trás, tendo sido assinados em 2015, até o momento, cinco Acordos de Cooperação e Facilitação de Investimentos com Moçambique, Angola, Malaui, México e Colômbia. 
Como se verificou no terceiro capítulo, esses acordos aliam alguns elementos à estrutura protetiva dos APPRIs tradicionais, com algumas inovações que já têm sido propagadas nos acordos de investimentos mais recentes, como a menção ao desenvolvimento sustentável, o respeito ao ambiente regulatório interno dos Estados, a previsão de responsabilidade social corporativa, dentre outras disposições. Seus principais pilares de sustentação consistem na governança institucional, nos mecanismos para mitigação de riscos e prevenção e solução de disputas e na facilitação de investimentos mediante agendas temáticas. Como se demonstrou no terceiro capítulo, os ACFIs resolveram algumas questões que geraram polêmica por não estarem previstas nos antigos TBIs brasileiros, como a possibilidade de pagamento através de títulos da dívida pública, e a exceção à livre transferência de capitais quando da ocorrência de graves dificuldades na balança de pagamento e nas finanças externas, aspectos que eram omissos nos TBIs brasileiros dos anos 1990 .

Entretanto, algumas críticas podem ser direcionadas a determinados aspectos materiais relevantes dos acordos, como o fato de o ACFI com Angola não possuir definições, remetendo-as ao ordenamento jurídico doméstico dos Estados, o que, se concluiu, pode levar à coexistência de vários conceitos, além da possibilidade de as leis nacionais das partes serem alteradas, como ocorreu com a lei de investimentos privados de Angola em agosto de 2015. Além disso, quanto à expropriação, o acordo trata apenas de expropriação de forma geral, sem distingui-la, se direta ou indireta, logo, em razão da ausência de especificidade, considera-se que pode haver margem para se considerar que o conceito cobre ambas, apesar de a expropriação indireta não estar especificada.

Os padrões de tratamento estabelecidos nos ACFIs seguem a premissa da não discriminação, com as cláusulas de tratamento nacional e de nação mais favorecida, contudo, encontra-se ausente disposição clara sobre o tratamento justo e equitativo, outro aspecto protetivo relevante atualmente. Contudo, conforme análise empreendida no capítulo três, pôde-se inferir que apesar de o tratamento justo e equitativo não estar diretamente tutelado, existem alguns elementos que pautam a atuação do Estado receptor de investimentos e, que do ponto de vista dos laudos arbitrais, são englobados pela amplitude deste conceito, como o devido processo legal e a transparência.

Ademais, importante registrar a disposição sobre responsabilidade social corporativa, que revela o propósito das Partes em promover um investimento responsável, atendo-se para os direitos trabalhistas, os direitos humanos, as questões ambientais, à 
promoção dos princípios da boa governança, dentre outros aspectos. Nesse diapasão, o respeito a essas premissas faz com que os investidores desses países atinjam uma espécie de selo, sendo reconhecidos como socialmente responsáveis e, ao mesmo tempo, contribuise para o respeito e desenvolvimento da comunidade local.

Noutro giro, salienta-se que a questão que suscita maior discussão nos ACFIs trata-se do mecanismo de prevenção e solução de controvérsias. Nesse contexto, salientase que, ao lado dos mecanismos jurisdicionais de solução de controvérsias sobre investimentos, há também a incidência dos mecanismos alternativos e preventivos de resolução de disputas, conforme demonstrado no quarto capítulo. De um lado, os meios alternativos encontram-se em consonância com os preceitos da solução pacífica de controvérsias, e, sendo aplicados ao Direito dos Investimentos, representam os institutos da negociação direta, da mediação, da conciliação e do fact-finding. De outro lado, no que tange aos métodos preventivos de controvérsias, estes têm sido desenvolvidos com o objetivo evitar futuros litígios, pelo que ao sinal de qualquer conflito de interesses, estes deverão ser resolvidos previamente, de forma a evitar sua evolução para uma disputa pelas vias arbitrais, causando desgastes, altos custos, e incertezas. Destaca-se que ambos os sistemas privilegiam uma solução negociada com base no interesse das partes, para que ao final, o acordo seja dotado de satisfação para os dois lados.

Nesse ínterim, o Brasil e os países com que assinou os tratados optaram por adotar um mecanismo tanto preventivo, quanto jurisdicional de solução de controvérsias. Constata-se que esta escolha se deu em função de o Brasil e os países com que se firmaram os acordos privilegiarem primordialmente uma solução negociada e baseada em interesses, tentando evitar-se ao máximo a resolução através do método jurisdicional arbitral. Como analisado no capítulo cinco, a sistemática preventiva baseia-se em dois instrumentos de governança institucional criados no âmbito dos ACFIs: o ombudsman ou Pontos Focais e o Comitê Conjunto.

Havendo uma reclamação, esta será encaminhada diretamente pelo investidor ao ombudsman, instituto preventivo alegadamente inspirado no ombudsman sul-coreano, modelo mundialmente reconhecido como bem-sucedido. Assim, infere-se que tal inciativa poderá ser benéfica ao investidor, pois, primeiramente, confere-lhe acesso direto ao ombudsman, em segundo lugar, este agente, designado apenas para cuidar do fomento das relações entre investidores e Estado receptor de investimentos, empreenderá esforços para resolver a questão, sempre em busca do melhor interesse das Partes e, por fim, atuará na 
mitigação de conflitos requerendo a cooperação das autoridades governamentais para que se atinjam melhorias nas políticas de investimento, procedimentos administrativos ou no regime regulatório do Estado receptor.

Caso não se alcance sucesso nesta fase, abre-se a oportunidade de que ela seja resolvida, ainda no âmbito preventivo, pelo Comitê Conjunto. Contudo, nesta via, o investidor já não terá mais legitimidade para atuar diretamente, e nem mesmo o ombudsman, que já havia atuado no caso o poderá fazer, dependendo de seu Estado de origem para que, através de seus representantes governamentais, acione o Comitê. Esclarece-se que, apesar de durante as reuniões bilaterais do Comitê se possibilite a presença de representante do investidor, a crítica que se lança é a de que, mesmo assim o investidor permanecerá sem ter iniciativa, pois este representante somente poderá participar da reunião uma vez que o Estado de origem do investidor encampe a reclamação. Caso o Estado de origem não tenha se convencido acerca de sua conveniência, o investidor continuará desprotegido.

Finalmente, caso a reclamação não seja resolvida nas fases preventivas, é possível ativar o mecanismo arbitral de solução de controvérsias entre Estados. Assim, novamente, o Estado de origem do investidor deverá avaliar de acordo com sua discricionariedade se encaminhará a demanda ao tribunal arbitral.

Nesse particular, ao trazer-se à baila o mecanismo de arbitragem estipulado pelos ACFIs e a premissa de valorização da negociação nas fases preventivas, propôs-se a analisar, levando em consideração o sistema de arbitragem entre Estados, se a negociação teria estímulos para prosperar e se alcançar uma solução negociada. Desse modo, o suporte teórico da teoria da sombra do direito, desenvolvida por Mnookin e Kornhauser, foi fundamental, pois disponibilizou bases relevantes que também podem ser aplicadas ao Direito dos Investimentos. A primeira delas é a necessidade de previsibilidade de resultados proporcionada por uma sombra do direito bem forte e definida, em que as partes têm conhecimento do direito aplicável e, juntamente com o mecanismo de solução de controvérsias escolhido, estas conseguirão ter previsibilidade dos futuros resultados do laudo arbitral. $\mathrm{Na}$ arbitragem investidor-Estado, caso as negociações na fase preventiva sejam infrutíferas, sabe-se que a possibilidade de o investidor levar a reclamação para a arbitragem é alta. Nessa hipótese, prevendo que o caso irá para a arbitragem e estimando seus resultados, mais especificamente tendo a percepção de seus futuros ganhos e perdas, as partes poderão engendrar melhores estratégias de negociação para que tentem minimizar 
os impactos dos resultados futuros, o que abrangerá custos de transação e o desgaste do relacionamento em longo prazo das partes, por isso, será de interesse delas empreenderem mais esforços na fase de negociação.

Porém, na arbitragem entre Estados, se findadas as negociações sem resultado negociado, há ainda a predominância da imprevisibilidade se o Estado de origem vai seguir adiante com a arbitragem, haja vista que, além de o investidor nacional ter de convencê-lo a ir adiante com a reclamação, isso envolverá também outros fatores, como os altos custos e o desgaste da relação política com o outro Estado. Logo, a sombra do direito neste caso é fraca, pois, em função desta relação de dependência, que se mostra desfavorável, não há como se prever com um pouco mais de certeza os resultados futuros, logo, não haverá estímulo ou capacidade para se alavancar as negociações nas fases preventivas, haja vista que se a negociação não for alcançada não se sabe se a demanda continuará, podendo a situação permanecer como está, e o investidor prosseguir prejudicado e, inclusive, desprotegido.

Para corroborar este raciocínio, trouxe-se à baila o caso da Coreia do Sul, em função de ter servido como inspiração para o modelo brasileiro. O Estado sul-coreano possui ao mesmo tempo mecanismos preventivos (ombudsman) e arbitragem investidorEstado. Os números que indicam a resolução de conflitos por meio do ombudsman são bastante elevados, alcançando, entre 2005 a 2014, um total de 2.866 casos. Ocorre que, contextualizando-se a teoria da sombra do direito ao caso da Coreia do Sul percebe-se que o sucesso de seu método preventivo também pode ser relacionado com a arbitragem investidor-Estado, haja vista que em razão dela, se aumenta a capacidade de alavancagem dos investidores nas negociações, havendo maior espaço para que os conflitos sejam resolvidos por acordos respaldados em interesses mútuos. Logo, caso estes casos não tivessem sido resolvidos pelo sistema preventivo, seria bem provável que se escalassem para a arbitragem de investimentos.

Desse modo, conclui-se que, considerando que o Brasil teve este arcabouço jurídico como paradigma, porém, o mesmo foi adaptado apenas parcialmente, além de terem corroborado para isso a posição historicamente resistente do país à arbitragem de investimentos, o mecanismo de solução de controvérsias entre Estados instituído acaba inibindo estímulos à negociação das partes nas fases pré-contenciosas, fazendo com que se prejudique o alcance de uma solução negociada baseada nos interesses das partes. 
Assim sendo, tem-se que, diante de um mundo contemporâneo em constante transformação, a criação de um novo acordo de investimentos pelo Brasil demonstra a intenção do país em participar mais ativamente da agenda do comércio internacional e do Direito dos Investimentos. Ainda é cedo para se afirmar se os ACFIs serão bem-sucedidos, contudo, o que se nota é uma recepção favorável dos investidores brasileiros, bem como de importantes parceiros comerciais do Brasil. Trata-se tarefa difícil encontrar um equilíbrio real entre proteção, promoção e facilitação dos investimentos, entretanto, para que se possa verificar se esses instrumentos serão mesmo eficazes, aguarda-se até a sua promulgação, por meio de decreto executivo de promulgação, publicidade oficial que terá o condão de vincular todos os sujeitos e órgãos jurisdicionais às previsões dos acordos. 


\section{REFERÊNCIAS}

ACCIOLY, Hildebrando; SILVA, G.E. do Nascimento e; CASELLA, Paulo Borba. Manual de Direito Internacional Público. 18. ed. São Paulo: Saraiva, 2010.

ACCORD entre le gouvernement de la Republique Français et le Gouvernement de la Republique Algerienne democratique et populaire sur l'encouragement et la protection reciproques des investissements. Disponivel em: $<$ http://www.itamaraty.gov.br/images/ed_atosinter/20151009-ACFI-port2.pdf>. Acesso em: 10 out. 2015 .

ACORDO de livre comércio entre Estados Unidos da América e República da Coreia. Chapter Eleven. Investment. Disponível em: $<$ http://investmentpolicyhub.unctad.org/Download/TreatyFile/2542>. Acesso em: 31 out. 2015 .

ACORDO entre o governo da república da coreia e o governo do Japão para liberalização, promoção e proteção do investimento. Disponível em: $<$ http://investmentpolicyhub.unctad.org/Download/TreatyFile/1727>. Acesso em: 2 nov. 2015 .

ALÉM, Ana Cláudia; CAVALCANTI, Carlos Eduardo. O BNDES e o apoio à internacionalização das empresas brasileiras: algumas reflexões. Revista do BNDES, v. 12, n.24, p.66-89, dez. 2005.

ALLEY, Edwin R. International Arbitration: The Alternative of the Stockholm Chamber of Commerce. The International Lawyer, v. 22, n. 3, p. 837-844, 1988.

ALMEIDA, Rafael Alves de; ALMEIDA, Tania; CRESPO, Mariana Hernandez. Tribunal multiportas: Investindo no capital social para maximizar o sistema de solução de conflitos no Brasil. Rio de Janeiro: FGV, 2012.

ALVAREZ, José E. The return of the State. Minnesota Journal of International Law, Minneapolis, Minn, v. 20, n. 2, p. 223-2264, 2011.

AMARAL JÚNIOR, Alberto do. Curso de direito internacional público. 2. ed. São Paulo: Atlas, 2011.

AMARAL JÚNIOR, Alberto do.; SANCHEZ, Michelle Ratton (Cood.) Regulamentação internacional dos investimentos: algumas lições para o Brasil. São Paulo: Aduaneiras, 2007.

ANGOLA. Lei $\mathbf{n}^{\circ}$ 14/15, de 07 de agosto de 2015. Lei do Investimento Privado. Diário da República Órgão Oficial da República de Angola, Luanda, 11 ago. 2015. Disponível em:

$<$ http://www.embangolacan.org/pdf/LEI\%20DO\%20INVESTIMENTO\%20PRIVADO\%20\%20NOVA\%20_PORTUGUES.PDF>. Acesso em: 27 set 2015. 
Lei $\mathrm{n}^{\circ}$ 20/11, de 19 de maio de 2011. Lei do Investimento Privado. Diário da República Órgão Oficial da República de Angola, Luanda, 20 maio. 2011. Disponível em: $<$ http://www.wipo.int/edocs/lexdocs/laws/pt/ao/ao027pt.pdf $>$. Acesso em: 15 out. 2015.

ARAÚJO, Nadia de; SOUZA JUNIOR, Lauro de Gama e. Os acordos bilaterais de investimento com a participação do Brasil e o direito interno - análise das questões jurídicas. In: CASELLA, Paulo Borba; MERCADANTE, Araminta de Azevedo (Coord.). Guerra comercial ou integração mundial pelo comércio?: a OMC e o Brasil. São Paulo: LTR, 1998.

AZEVEDO, Débora Bithiah de. O capital estrangeiro terá regras estáveis por 25 anos?: os acordos de promoção e proteção de investimentos em tramitação no congresso nacional. Cadernos ASLEGIS, Brasília, v.5, n.4, p.21-30, maio/ago. 2001. Disponível em: $<$ http://bd.camara.gov.br/bd/handle/bdcamara/11190>. Acesso em: 2 out. 2013.

Os acordos para a promoção e a proteção recíproca de investimentos assinados pelo Brasil. Brasília: Câmara dos Deputados, p.1-13, 2001. Disponível em: $<$ http://bd.camara.gov.br/bd/bitstream/handle/bdcamara/2542/acordos_promocao_azevedo. pdf? sequence=1>. Acesso em: 2 mai. 2014.

BAPTISTA, Luiz Olavo. Investimentos Internacionais no Direito Comparado e Brasileiro. Porto Alegre: Livraria do advogado, 1998.

BARBOSA, Denis Borges. Direito de acesso do capital estrangeiro. In: RIBEIRO, Marilda Rosado de Sá (Org.). Direito Internacional dos Investimentos. Rio de Janeiro: Renovar, 2014.

BARROCAS, Manuel Pereira. Manual de arbitragem. Coimbra: Almedina, 2010.

BENTO, Lucas. Time to join the "BIT club"? promoting and protecting Brazilian investments abroad. The American Review of International Arbitration, New York, v. 24, n.2, p. 157-191, 2013.

BERCOVICI, Gilberto. Direito econômico do petróleo e dos recursos minerais. São Paulo: Quartier Latin, 2011.

BERNASCONI-OSTERWALDER, Nathalie; BRAUCH, Martin Dietrich. Comparative Commentary to Brazil's Cooperation and Investment Facilitation Agreements (CIFAs) with Mozambique, Angola, Mexico, and Malawi. International Institute for Sustainable Development (IISD), p.1-16, September 2015. Disponível em: $<$ https://www.iisd.org/sites/default/files/publications/commentary-brazil-cifas-acfismozambique-angola-mexico-malawi.pdf $>$. Acesso em: 15 out. 2015.

BIBAS, Stephanos. Plea bargaing outside the shadow of trial. Harvard Law Review, v.117, n. 8, p.2463-2547, 2004.

BISHOP, R. Doak, CRAWFORD, James, REISMAN, W. Michael. Foreign investment disputes: cases, materials and commentary. The Hague: Kluwer Law International, 2005. 
BJORKLUND, Andrea K. National treatment In: REINISCH, August (Org.). Standards of investment protection. Oxford: Oxford University Press, 2008.

BORJA, Célio de Oliveira. O capital estrangeiro no direito brasileiro. Revista do Advogado, São Paulo, v.26, n.88, p.32-42, 2006.

BRASIL. Acordo de Cooperação e Facilitação de Investimentos entre o Governo da República Federativa do Brasil e o Governo da República de Angola. Luanda, $1^{\circ}$ de abril de 2015. Disponível em: $<$ http://www.itamaraty.gov.br/index.php?option=com_content\&view $=$ article\&id $=8520$ :aco rdo-brasil-angola-de-cooperacao-e-facilitacao-de-investimentos-acfi-luanda-1-de-abril-de2015\&catid=42\&Itemid=280\&lang=pt-BR $>$. Acesso em: 15 set. 2015.

- Acordo e Cooperação e Facilitação de Investimentos entre a República Federativa do Brasil e o Governo da República da Colômbia. Bogotá, 9 de outubro de 2015. Disponível em: $<\mathrm{http}: / / \mathrm{www}$.itamaraty.gov.br/images/ed_atosinter/20151009-ACFIport2.pdf>. Acesso em: 10 out. 2015.

Acordo e Cooperação e Facilitação de Investimentos entre a República Federativa do Brasil e a República do Maláui. Brasília, 25 de junho de 2015. Disponível em: <http://investmentpolicyhub.unctad.org/Download/TreatyFile/3472>. Acesso em: 30 set. 2015.

Acordo e Cooperação e Facilitação de Investimentos entre a República Federativa do Brasil e os Estados Unidos do México. Brasília, 26 de maio de 2015. Disponível em: $<$ http://investmentpolicyhub.unctad.org/Download/TreatyFile/3458>. Acesso em: 30 set. 2015.

Acordo e Cooperação e Facilitação de Investimentos entre a República Federativa do Brasil e o Governo da República de Moçambique. Maputo, 30 de março de 2015.2 Disponível em: $<$ http://www.itamaraty.gov.br/index.php?option=com_content\&view $=$ article $\&$ id $=8511$ :aco rdo-brasil-mocambique-de-cooperacao-e-facilitacao-de-investimentos-acfi-maputo-30-demarco-de-2015\&catid=42\&Itemid=280\&lang=pt-BR >. Acesso em: 30 set. 2015.

Acordo entre o Governo da República Federativa do Brasil e o Governo da República Francesa sobre Promoção e Proteção Recíproca de Investimento. Paris, 21 março de 1995. Sistema [de] Atos Internacionais, Ministério das Relações Exteriores, Brasília, DF, 1995. Art. 30. Disponível em: <http://dai-mre.serpro.gov.br/atosinternacionais/bilaterais/1995/b_17/>. Acesso em: 9 out. 2015.

Acordo para a Promoção e a Proteção Recíproca de Investimentos entre o Governo da República Federativa do Brasil e o Governo da República da Coréia. Brasília, 1 de setembro de 1995. Disponível em: $<$ http://investmentpolicyhub.unctad.org/Download/TreatyFile/509>. Acesso em: 9 out. 2015 .

Advocacia Geral da União. Parecer nºQ-104, de 29 fevereiro 1996. Diário Oficial [da] República Federativa do Brasil, Brasília, 11 de junho de 1996. 
Advocacia Geral da União. Parecer n ${ }^{\circ}$ LA-01, de 03 de outubro de 2008. Diário Oficial [da] República Federativa do Brasil, Brasília, 23 de agosto de 2010.

Agência Brasileira de Promoção de Exportações e Investimentos. Boletim de

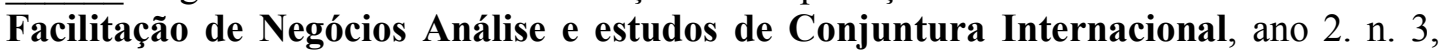
$2015 . \quad$ Disponível em: $<$ http://arq.apexbrasil.com.br/portal/BoletimNegocios_Edicao03.pdf $>$.

Banco Central do Brasil. Capitais Brasileiros no Exterior (CBE) - Ano-Base 2012. Disponível em: <http://www4.bcb.gov.br/rex/CBE/Port/ResultadoCBE2012p.pdf>. Acesso em: 30 mai. 2014.

2013.
. Banco Central do Brasil. Capitais Brasileiros no Exterior (CBE) - Ano-Base
Disponível $<$ http://www4.bcb.gov.br/rex/CBE/Port/ResultadoCBE2013p.pdf $>$.Acesso em: 15 out. 2015

$\overline{\text { Disponível }}$

Banco Nacional do Desenvolvimento Econômico e Social. Foreign Trade. $<$ http://www.bndes.gov.br/SiteBNDES/bndes/bndes en/Institucional/The BNDES Abroa d/Foreign_Trade/>. Acesso em: 01 jul 2014.

Conselho Monetário Nacional. Resolução n 3.689, de 16 de dezembro de 2013. Regulamenta, no âmbito do Banco Central do Brasil, as disposições sobre o capital estrangeiro no País e sobre o capital brasileiro no exterior. Diário Oficial [da] República Federativa do Brasil, Brasília, 17 de dezembro de 2013.

. Conselho Monetário Nacional. Resolução n 3.844, de 23 de março de 2010. Dispõe sobre o capital estrangeiro no País e seu registro no Banco Central do Brasil, e dá outras providências. Diário Oficial [da] República Federativa do Brasil, Brasília, 26 de março de 2010. Senado, 1988.

Constituição (1988). Constituição da República Federativa do Brasil. Brasília:

Exposição de Motivos n³7, de 16 de fevereiro de 1995. Diário do Congresso Nacional, Brasília, 15 de março de 1995.

. Lei $\mathrm{n}^{\circ} 4.131$, de 3 de setembro de 1962. Disciplina a aplicação do capital estrangeiro e as remessas de valores para o exterior e dá outras providências. Diário Oficial [da] República Federativa do Brasil, Brasília, 27 de setembro de 1962.

Lei $\mathrm{n}^{\circ} 5.709$ de 7 de outubro de 1971. Regula a aquisição de imóvel rural por estrangeiro residente no país ou pessoa jurídica estrangeira autorizada a funcionar no Brasil, e dá outras providências. Diário Oficial [da] República Federativa do Brasil, Brasília, 11 de outubro de 1971.

- Ministério das Relações Exteriores. Nota 194 Acordo Brasil-México de Cooperação e Facilitação de Investimentos. Cidade do México, 26 de maio de 2015. Disponível 
$<$ http://www.itamaraty.gov.br/index.php?option=com_content\&view $=$ article\&id=9890:aco rdo-brasil-mexico-de-cooperacao-e-facilitacao-de-investimentos-cidade-do-mexico-26-demaio-de-2015\&catid $=42 \&$ Itemid $=280 \&$ lang $=$ pt-BR $>$.

- Ministério das Relações Exteriores. Nota 244 Acordo Brasil-Malaui de Cooperação e Facilitação de Investimentos (ACFI), Brasília, 25 de junho de 2015. Disponível

em: $<$ http://www.itamaraty.gov.br/index.php?option=com_content\&view=article\&id=10333:ac ordo-brasil-malaui-de-cooperacao-e-facilitacao-de-investimentos-acfi\&catid=42\&lang=ptBR\&Itemid $=280>$.

- Ministério do Desenvolvimento, Indústria e Comércio Exterior. Governo incentiva investimentos de qualidade na África. Disponível em: $<$ http://www.desenvolvimento.gov.br/sitio/interna/noticia.php?area=5\&noticia=13202>. Acesso em: 1 jun. 2014.

. Ministério do Desenvolvimento, Indústria e Comércio. Brasil e Maláui assinam $\overline{\text { acordo }}$ de cooperação e facilitação de investimentos, 25 jun. 2015. Disponível em: $<$ http://www.desenvolvimento.gov.br/portalmdic/sitio/interna/noticia.php?area=1\&noti cia $=13872>$. Acesso em: 10 ago. 2015.

Exterior - CAMEX. $<$ http://www.desenvolvimento.gov.br/sitio/interna/interna.php?area=1\&menu=1920>. Acesso em: 10 ago. 2015.

. Ministério do Desenvolvimento, Indústria e Comércio. Godinho analisa momento de oportunidades no comércio exterior, 25 out. 2013. Disponível em: $<$ http://www.desenvolvimento.gov.br/portalmdic/sitio/interna/noticia.php?area=5\&noticia $=12762>$. Acesso em: 30 mai. 2014 .

. Parecer da Comissão de Constituição e Justiça e de Redação, de 21 de julho de 1997, ao Projeto de Decreto Legislativo n³95 de 2000. Diário da Câmara dos Deputados, Brasília, 20 de janeiro de 2000.

. Parecer da Comissão de Relações Exteriores e Defesa Nacional [ao Projeto de Decreto Legislativo n 367 de 1996]. Exposição do Deputado Luiz Gushiken. Diário da Câmara dos Deputados, Brasília, 4 de maio de 2000.

. Presidência da República. Casa Civil. Decreto no 4.311, de 23 de julho de 2002. Disponível em: <http://www.planalto.gov.br/ccivil_03/decreto/2002/D4311.htm>. Acesso em: 29 out. 2015 .

BRAUCH, Martin Dietrich. The Brazil-Mozambique and Brasil-Angola cooperation and investment facilitation agreements (CIFAs): a descriptive overview. Investment Treaty News. International Institute for Sustainable Development, 21 mai. 2015. Disponível em: <https://www.iisd.org/itn/2015/05/21/the-brazil-mozambique-and-brazilangola-cooperation-and-investment-facilitation-agreements-cifas-a-descriptiveoverview/>. Disponível 14 out. 2014. 
BRILLO, Romulo. A prevenção de controvérsias investidor-Estado e alternativas à arbitragem investidor-Estado. In: RIBEIRO, Marilda Rosado de Sá. Direito Internacional dos Investimentos. Rio de Janeiro: Renovar, p.271-299, 2014.

BROCHES, Aron. The Convention on the Settlement of Investment Disputes between States and Nationals of Other States. Recueil des Cours, n. 2, p. 331-410, 1972.

BROWN, Chester (Ed.). Commentaries on selected model investment treaties. Oxford: Oxford University Press, 2013.

BROWN, Chester. Introduction: the development and importance of the model bilateral investment treaty. In: BROWN, Chester. Commentaries on selected model investment treaties. Oxford: Oxford University Press, p.1-13, 2013.

BUSCH, Marc L.; REINHARDT, Eric. Bargaining in the shadow of the law: early settlement in GATT/WTO disputes. Fordham International Law Journal, v. 21, issue 1, p.158-172, 2000.

CALVO, Carlos. Derecho Internacional teórico y prático de Europa y América. Paris: Durand et Pedone-Lauriel, 1868. t.1. Disponível em: $<$ https://books.google.com.br/books?id=KsBBAAAAYAAJ\&printsec=frontcover\&hl=ptBR\&source $=$ gbs_ge_summary_r\&cad $=0 \# \mathrm{v}=$ onepage\&q\&f=false $>$. Acesso em: 04 out. 2015.

CANADÁ. Agreement Between the Government of Canada and the Government of the Republic of Costa Rica for the Promotion and Protection of Investments, San José, 18 de março de 1998. Disponível em: <http://www.treaty-accord.gc.ca/texttexte.aspx?id=101533 >. Acesso em: 29 set. 2015.

CANÇADO TRINDADE, Antonio Augusto. As Nações Unidas e a Nova Ordem Econômica Internacional (com atenção especial aos Estados latino-americanos). Revista de Informação Legislativa, Brasília, ano 21, n. 81, p. 213-232, jan./mar. 1984.

CAPPELLETTI, Mauro. Os métodos alternativos de solução de conflitos no quadro do movimento universal de acesso à justiça. Revista de Processo, São Paulo, São Paulo, ano 19, n. 74, p.82-97, 1994.

CARREAU, Dominique; JUILLARD, Patrick. Droit international économique. 5. ed. Paris: Dalloz, 2013.

CARVALHO RAMOS, André de. Direito dos estrangeiros no Brasil: a imigração, direito e ingresso e os direitos dos estrangeiros em situação irregular. In: SARMENTO, Daniel; IKAWA, Daniela; PIOVESAN, Flávia. Igualdade, Diferença e Direitos Humanos. Rio de Janeiro: Lumen Juris, p. 721-745, 2008.

CASELLA, Paulo Borba. Fundamentos do direito internacional pós-moderno. São Paulo: Quartier Latin, 2008. 
CASELLA, Paulo Borba; MERCADANTE, Araminta de Azevedo (Coord.). Guerra comercial ou integração mundial pelo comércio?: a omc e o brasil. São Paulo: LTR, 1998.

CASSESE, Antonio. International Law. 2. ed. Oxford: Oxford University Press, 2005.

CERVO, Amado Luiz; BUENO, Clodoaldo. História da política exterior do Brasil. Brasília: UNB, 2008.

CHAKRAVARTY, Surajeet; MACLEOD,W. Bentley. Contracting in the shadow of the law. The RAND Journal of Economics, v. 40, n. 3, p. 533-557, 2009.

CHILE e Brasil discutem acordos de investimento. Revista Exame, São Paulo. Disponível em: <http://exame.abril.com.br/brasil/noticias/chile-brasil-discutem-acordo-investimentos589805>. Acesso em: 30 maio 2014.

COLLIER, John; LOWE, Vaughan. The settlement of disputes in international law: institutions and procedures. Oxford: Oxford University Press, 1999.

COMEX DO BRASIL. Brasil apresenta proposta de investimento na África do Sul, Angola, Moçambique e Nigéria. Disponível em: < http://comexdobrasil.com/brasilapresenta-proposta-de-acordo-de-investimento-na-africa-sul-angola-mocambiquenigeria/>.

CONFEDERAÇÃO NACIONAL DA INDÚSTRIA (CNI). Interesses da indústria na América do Sul: Investimentos. Brasília: CNI, 2015.

. Investimentos estrangeiros diretos no Brasil - 2014 os regimes e políticas de IED: tendências recentes no mundo e no Brasil. Brasília: CNI, 2015.

Os investimentos brasileiros no exterior - 2014: O desempenho exportador das empresas multinacionais brasileiras. Brasília, 2015.

. Relatório dos investimentos brasileiros no exterior 2013: recomendações de políticas públicas par ao Brasil. Brasília: CNI, 2013.

COLLIER, John, LOWE, Vaughan. The settlement of disputes in international law. Oxford: Oxford University Press, 1999.

COZENDEY, Carlos Marcio Bicalho; CAVALCANTE, Pedro Mendonça. Novas Perspectivas para Acordos Internacionais de Investimentos - o Acordo de Cooperação e Facilitação de Investimentos (ACFI). Cadernos de Política Exterior, Brasília, v. 1, n. 2, p.87-109, out. 2015.

COREIA DO SUL. Ato $\mathbf{n}^{\circ}$ 5559, de 16 de setembro de 1998. Ato de Promoção do Investimento Estrangeiro. Disponível em: $<$ http://legal.un.org/avl/pdf/ls/Shin_RelDocs.pdf>. Acesso em: 9 nov. 2015. 
. Foreign Investment Ombudsman Annual Report 2014. 2015. Disponível em: $<$ http://125.131.31.47/Solars7DMME/004/15Foreign_Investment_Ombudsman_Annual_R eport2014.pdf >. Acesso em: 5 nov. 2015.

Foreign Investment Promotion Act (Republic of Korea). Artigo 15-2(1). Disponível em: < http://legal.un.org/avl/pdf/ls/Shin_RelDocs.pdf $>$. Acesso em: 26 out. 2015.

Disponível

Office of the foreign investment ombudsman. Notice \& Information. $<$ http://www.investkorea.org/ikwork/ombsman/eng/au/index.jsp?num $=8 \&$ no $=609280001 \&$ bno $=208140021 \&$ page1 $=1 \&$ sort_num=534> . Acesso em: 13 set. 2015.

Office of the foreign investment ombudsman. Overview \& Mission. Disponível em: <http://www.i-ombudsman.or.kr/eng/au/index.jsp?num=3>. Acesso em: 5 out. 2015.

Ombudsman's message, 2015. Disponível em: <http://www.i-

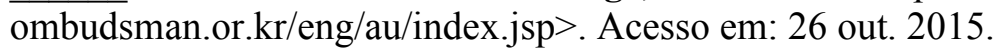

Ombudsman's Office. Sharing Korea's Investment Aftercare Knowhow. A Brazilian government delegation visited Korea for an in-depth discussion on Korea's Foreign Investment Ombudsman system. Disponível em: $<$ http://www.investkorea.org/publish/data/bbs/bulletin/img/10/IKE_03_1410.pdf $>$. Acesso em: 15 set. 2015.

CORRÊA, Daniela; LIMA, Gilberto Tadeu. O comportamento recente do investimento direto brasileiro no exterior em perspectiva. Revista de Economia Política, v.28, n.2, p. 249-268, 2008.

CORTE INTERNACIONAL DE ARBITRAGEM CENTRO INTERNACIONAL DE ADR. Regulamento de Arbitragem Regulamento de Mediação. Disponível em: $<$ http://www.iccwbo.org/Data/Documents/Buisness-Services/Dispute-ResolutionServices/Mediation/Rules/2012-Arbitration-Rules-and-2014-Mediation-RulesPORTUGUESE-version/>.

COSTA, José Augusto Fontoura. Brasil e arbitragem internacional de investimentos: realidades e possibilidades. In RIBEIRO, Marilda Rosado de Sá (Org.). Direito Internacional dos Investimentos. Rio de Janeiro: Renovar, p.247-270, 2014.

. Direito Internacional do Investimento Estrangeiro. Curitiba: Juruá, 2010.

Inversión extranjera: patrones de cooperación y competencia. Revista Aportes para la Integración Latinoamericana, La Plata, año 13, n.16, jun, 2007. Disponível em: $<$ http://132.248.9.1:8991/hevila/Aportesparalaintegracionlatinoamericana/2007/vol13/n o16/4.pdf>. Acesso em: 2 out. 2012.

. Investidores brasileiros e arbitragem internacional. International Centre for Trade and Sustainable Development. Pontes, v.4, n.6, 2008. Disponível em: $<$ http://ictsd.org/i/news/pontes/37062/>. Acesso em: 2 out. 2012. 
Modelos de solução de controvérsia investidor-Estado: os mecanismos nacionais e internacionais. In: AMARAL JÚNIOR, Alberto do; SANCHEZ, Michelle Ratton. (Coord.). Regulamentação internacional dos investimentos: algumas lições para o Brasil. São Paulo: Aduaneiras, p. 325-354, 2007.

Proteção e promoção do investimento estrangeiro no mercosul - uma ferramenta para a implementação de um bom clima de investimentos? Disponível em: $<$ http://www.scielo.br/scielo.php?script=sci_arttext\&pid=S0034-

$73292006000200004 \& \operatorname{lng}=$ pt\&nrm=iso\&userID=-2>. Acesso em: 02 out 2012.

- Proteção internacional do investimento estrangeiro no MERCOSUL. Florianópolis: GEDAI, 2012

. Valor Econômico, Brasília, 30 de jul. 2015. ACFIs e (a falta de) proteção dos investidores. Disponível em: $<$ http://www.valor.com.br/colunistas/Jos\%C3\%A9\%20Fontoura\%20Costa $>$. Acesso em: 6 nov. 2015.

COSTA, José Augusto F.; CARREGARO, Ana Carolina C.; ANDRADE, Thiago P. Mecanismo complementar do icsid: uma alternativa para investidores brasileiros? Revista Direito GV, São Paulo, v. 3, n. 2, p.59-76, jul./dez. 2007.

COSTA, José Augusto Fontoura; GABRIEL, Vivian Daniele Rocha. O Brasil, ACFIs e a arbitragem de investimentos. In: Associação Portuguesa de Arbitragem. (Org.). Revista Internacional de Arbitragem e Conciliação. Ano VIII - 2015. 1ed.Lisboa: Almedina, 2015, v. 1, p. 63-82.

COUTINHO, Luciano; HIRATUKA, Celio; SABATINI, Rodrigo. O investimento direto no exterior como alavanca dinamizadora da economia brasileira. In BARROS, Octavio de; GIAMBIAGI, Fábio (Org.). Brasil globalizado. Rio de Janeiro: Campus, 2008.

CRAWFORD, James. Brownlie's principles of public international law. 18th. Oxford: Oxford University Press, 2012.

CYRINO, Álvaro Bruno, OLIVEIRA JÚNIOR, Moacir de Miranda; BARCELLOS, Erika Penido. Evidências sobre a internacionalização de empresas brasileiras. In: OLIVEIRA JÚNIOR, Moacir de Miranda (Org.). Multinacionais brasileiras: internacionalização, inovação e estratégia global. Porto Alegre: Bookman, 2010.

DAN, Wei. Acordos bilaterais de promoção e proteção de investimentos: práticas do brasil e da china. Nação e Defesa: Visões Globais para a Defesa. Lisboa: Instituto da Defesa Nacional, n.125, primavera, 2010.

DI PIETRO, Maria Sylvia Zanella. Direito administrativo. 27. ed. São Paulo: Atlas, 2014.

DIAS, Bernadete de Figueiredo. Investimentos estrangeiros no Brasil e no direito internacional. Curitiba: Juruá, 2010. 
DOLZER, Rudolph; SCHREUER, Christoph. Principles of international investment law. Oxford: Oxford University Press, 2008.

DUGAN, A.; WALLACE, D.; RUBIN, N.; SABAHI, B. Investor-state arbitration. Oxford: Oxford University Press, 2008.

ELKINS, Zachary; GUZMAN, Andrew T.; SIMMONS, Beth. Competing for Capital: The Diffusion of Bilateral Investment Treaties, 1960-2000. University of Illinois Law Review, Illinois, n.265, p. 265-304, 2008. Disponível em: $<$ http://scholarship.law.berkeley.edu/facpubs/433>. Acesso em: 30 jun. 2014.

EXAME. Chile e Brasil discutem acordos de investimento. Disponível em: $<$ http://exame.abril.com.br/brasil/noticias/chile-brasil-discutem-acordo-investimentos589805>. Acesso em: 30 maio 2014.

FADDA, Fernanda. Regime constitucional e legal dos investimentos estrangeiro no Brasil.In: RIBEIRO, Marilda Rosado de Sá (Org.). Direito Internacional dos Investimentos. Rio de Janeiro: Renovar, 2014.

FEDERAÇÃO DAS INDÚSTRIAS DO ESTAdO DE SÃO PAULO. Position Paper Proposals for the External Integration of Industry - 2014. São Paulo: FIESP, 2014.

FEUER, Guy; CASSAN, Hervé. Droit international du développement. 2ed. Paris: Dalloz, 1991.

FISCHER, Roger; URY, William. Getting to Yes: Negotiating Agreement Without Giving In. 2th. Random House Business Books, 1991.

FLEURY, Afonso, FLEURY, Maria Tereza Leme. Brazilian multinationals: competences for internationalization. Cambridge: Cambridge University press, 2011.

Multinacionais brasileiras: competências para a internacionalização Rio de Janeiro: FGV, 2012.

FOREIGN TRADE INFORMATION SYSTEM. Information on Brazil: bilateral investment treaties. Disponível em $<$ http://www.sice.oas.org/ctyindex/BRZ/BRZBits_e.asp>. Acesso em: 2 out 2012.

FORTUNE. Global 500. 2013. Disponível em: <http://fortune.com/global500/royal-dutchshell-plc-1/>. Acesso em: 1 jul. 2014.

FRANCK, Susan. Challenges facing investment disputes: reconsidering dispute resolution in international investment agreements In: SAUVANT, Karl P. (Ed.). Appeals Mechanism in International Investment Disputes, Oxford: Oxford University Press, p.143-192, 2008.

FRIEDMAN, Thomas. O mundo é plano: uma breve história do século XXI. Rio de Janeiro: Objetiva, 2005. 
FUNDAÇÃO DOM CABRAL. Ranking FDC das multinacionais brasileiras 2013: os impactos da política externa na internacionalização de empresas brasileiras. Disponível em: $<$ http://www.fdc.org.br/imprensa/Documents/2013/ranking_multinacionais_brasileiras 2013.pdf>. Acesso em: 29 jun. 2014.

Ranking FDC das multinacionais brasileiras 2015: a capacidade de adaptação

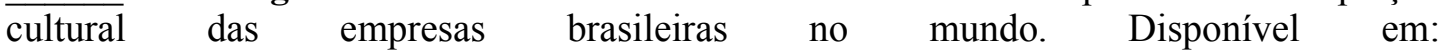
$<$ http://www.fdc.org.br/blogespacodialogo/Documents/2015/ranking_fdc_multinacionais_ brasileiras2015.pdf $>$.

FUNDAÇÃO GETÚLIO VARGAS. Infográfico: nossas empresas ganham o mundo. Disponível em: $<$ http://bibliotecadigital.fgv.br/dspace/bitstream/handle/10438/7121/Ed.\%2022\%20\%20Infografico\%20-\%20\%28Site\%29.pdf?sequence=1>. Acesso em: 29 jun. 2014.

FUX, Luiz; NERY JR., Nelson; WAMBIER, Teresa Arruda Alvim (Coord.). Processo e Constituição: Estudos em homenagem aos Professor José Carlos Barbosa Moreira. São Paulo: Editora Revista dos Tribunais, 2006.

GABBAY, Daniela; FALECK, Diego; TARTUCE, Fernanda. Meios alternativos de solução de conflitos. Rio de Janeiro: FGV, 2013.

GABRIEL, Vivian Daniele Rocha; COSTA, José Augusto Fontoura. O MERCOSUL e as controvérsias sobre investimentos. Revista da Secretaria do Tribunal Permanente de Revisão, ano 3, n. 5, p. 267-284, 2015.

GALANTER, Marc. Compared to what? Assessing the quality of dispute processing. Denver University Law Review, n. 66, issue 3, p. 1989.

GALBRAITH, Jay R. Designing global corporation. San Francisco: Jossey-Bass, 2000.

GARCIA NETO, Paulo Macedo. Investment arbitration in Brasil: the landscape of investment arbitration in Brazil and why Brazil should become a more important player in the investment arbitration arena. In: LEVY, Daniel de Andrade; BORJA, Ana Gerdau de; PUCCI, Adriana Noemi. Investment protection in Brazil. Alphen aan den Rijn: Wolters Kluwer, p.3-16, 2013.

GARCIA, Ana E. Saggioro. A internacionalização de empresas brasileiras durante o governo Lula: uma análise crítica da relação entre capital e Estado no Brasil contemporâneo. 2012. 403f. Tese (Doutorado em Relações Internacionais) - Pontifícia Universidade Católica do Rio de Janeiro, Instituto de Relações Internacionais. 2012.

GIUSTI, Gilberto; TRINDADE, Adriano Drummond C. As arbitragens internacionais relacionadas a investimentos: a convenção de Washington, o icsid e a posição do brasil. Revista de Arbitragem e Mediação, São Paulo, n.7, ano 2, p. 49-77, out./dez. 2005.

GÓMEZ-PALACIO, Ignacio; MUCHLINSKI, Peter. Admission and establishment. In: MUCHLINSKI, Peter; ORTINO, Federico; SCHREUER, Christoph (Coord.). The Oxford Handbook of International Investment Law. Oxford: Oxford University Press, 2008. p. 227-258. 
GORDON, K., POHL, J.; BOUCHARD, M. Investment Treaty Law, Sustainable Development and Responsible Business Conduct: a Fact Finding Survey, OECD Working Papers on International Investment, 2014.

GRAU, Eros Roberto. A ordem econômica na Constituição de 1988: interpretação e crítica. 17. ed. São Paulo: Malheiros, 2015.

GUZMAN, Andrew T. Why ldes sign treaties that hurt them: explaining the popularity of bilateral investment treaties. Disponível em: $<$ http://works.bepress.com/andrew_guzman/15/>. Acesso em: out. 2012.

HAMAMOTO, Shotaro; NOTTAG, Luke. Japan In: BROWN, Chester (Ed.). Commentaries on selected model investment treaties. Oxford: Oxford University Press, p. 393-424, 2013.

HAMILTON, Jonathan; GRANDO, Michelle, White \& Case. Brazil and the Future of Investment Protections. Latin Arbitration Law. Disponível em: $<$ http://www.latinarbitrationlaw.com/brazil-and-the-future-of-investment-protections/>. Acesso em: 15 set. 2015.

HEYWOOD, Andrew. Politics. 4th. New York: Palgrave Macmillan, 2013.

HUCK, Hermes Marcelo. Contratos com o Estado: aspectos de Direito Internacional. São Paulo: Editora Aquarela, 1989.

INGLESIAS, Roberto; COSTA, Katarina. O investimento direto brasileiro na África: características, condicionantes e perspectivas. Pontes, v.8, n.2, 2012. Disponível em: $<$ http://www.ictsd.org/bridges-news/pontes/news/o-investimento-direto-brasileiro-na$\% \mathrm{C} 3 \% \mathrm{~A} 1$ frica-caracter\%C3\%ADsticas-condicionantes-e>. Acesso em: 18 set. 2014.

INTERNATIONAL CENTRE FOR SETTLEMENT OF INVESTMENT DISPUTES. Bayindir Insaat Turizm Ticaret Ve Sanayi A.S. v. Islamic Republic of Pakistan, ICSID Case n. ARB/03/29, Award, 27 Aug. 2009.

Database of ICSID Member States. Disponível em:

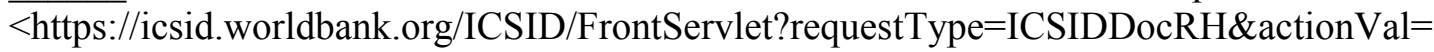
ShowDocument\&language=English $>$. Acesso em: 17 out. 2014.

Cases.

Disponível

em:

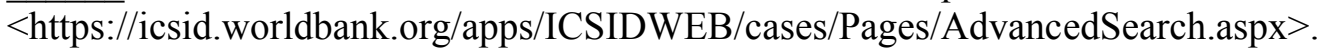
Acesso em: 5 out. 2015.

Emilio Augustin Maffezini v. The Kingdom of Spain, ICSID Case n. ARB/97/7, Award, 13 Nov., 2000.

ICSID Caseload-Statistics (Issued 2015-1). 2015. Disponível em: $<$ https://icsid.worldbank.org/apps/ICSIDWEB/resources/Documents/ICSID\%20Web\%20S tats\%202015-1\%20(English)\%20(2)_Redacted.pdf>. Acesso em: 25 set 2015. 
. Metalclad Corporation v. The United Mexican States, ICSID Case n. ARB(AF)/97/1, Award, 30 Aug. 2000.

.MTD Equity Sdn. Bhd. And MTD Chile S.A. v. Republic of Chile, ICSID Case $\overline{\text { n. } \mathrm{ARB}} / 01 / 7$, Award, 25 May 2004.

ICSID Convention, Regulation and Rules. Report of the executive directors on the convention on the settlement of investment disputes between states and nationals of other states. 2006. Disponível em: $<$ https://icsid.worldbank.org/ICSID/StaticFiles/basicdoc/CRR_English-final.pdf $>$. Acesso em: 27 set. 2015.

. Sempra Energy International v. The Argentine Republic, ICSID Case n. ARB/02/16, Award. 28 Sep. 2007.

Waste Management Inc. v. United Mexican State (Number 2), ICSID Case n. ARB(AF)/98/2, Award, 30 Apr. 2004.

INTERNATIONAL COURT OF JUSTICE. Case concerning the Barcelona Traction, Light and Power Company Limited (Belgium v. Spain). Judgement, 5 fev. 1970. ICJ Reports, 1970.

INTERNATIONAL MONETARY FUND. Balance of payments manual. 15th. Washington: IMF, 1993.

ISMAIL, Mohamed A.M. International Investment Arbitration: Lessons from development in the Mena Region. Burlington: Ashgate USA, 2013.

JAPÃO. Agreement Between Japan and the Socialist Republic of Viet Nam for the Liberalization, Promotion and Protection of Investment, Tóquio, 14 de novembro de 2003. Disponível em: <http://www.mofa.go.jp/region/asia-paci/vietnam/agree0311.pdf>. Acesso em: 3 nov. 2015.

JESSUP, Philip C. Direito transnacional. Brasil: Editora Fundo de Cultura Brasil Portugal, 1965.

JOUBIN-BRET, Anna. Admission and establishment in the context of investment protection. In: REINISCH, August (Org.). Standards of investment protection. Oxford: Oxford University Press, p. 9-28, 2008.

JUILLARD, Patrick. L'évolution des sources du droit des investissements. Recueil des cours, Leiden p. 9-216, 1994.

KAHN, Philippe; WALDE, Thomas W. (Org.). Les aspects nouveaux du droit des investissements internationaux. Académie de droit international de La Haye, Leiden and Boston: Martinus Nijhoff Online, 2007. Disponível em: $<$ http://nijhoffonline.nl/book?id=cdu9789004153721_cdu9789004153721 $>$. Acesso em: 14 out 2012. 
KALICKI, Jean; MEDEIROS, Suzana. Investment arbitration in brazil: revisiting brazil's traditional reluctance towards ICSID, BITs and investor-state arbitration. Arbitration International, v.24, issue 3, p. 441-442, 2008.

KINGSBURY, Benedict; SCHILL, Stephan. Investor-State Arbitration as Governance: fair and equitable treatment, proportionality and the emerging global administrative law. New York University School of Law,Public Law \& Legal Theory Research Paper, New York, n. 09-46, 2009. Disponível em: $<$ http://papers.ssrn.com/sol3/papers.cfm?abstract_id=1466980>. Acesso em: 01 nov. 2015.

KLEINHEISTERKAMP, Jan. O Brasil e as disputas com investidores estrangeiros. In: CHEREM, Mônica Teresa Costa Sousa; DI SENA JÜNIOR, Roberto (Org.). Comércio internacional e desenvolvimento: uma perspectiva brasileira. São Paulo: Editora Saraiva, p. 157-191, 2004.

KLOSS, Karla. Investimentos estrangeiros: regulamentação internacional e acordos bilaterais. Curitiba: Juruá, 2010.

KOLO, Abba; Wälde, Thomas. Capital transfer restrictions under modern investment treaties. In: REINISCH, August (Org.). Standards of investment protection. Oxford: Oxford University Press, p. 205-243, 2008.

KOTERA, Akira. Regulatory transparency. In MUCHLINSKI, Peter; ORTINO, Federico; SCHREUER, Christoph (Coord). The Oxford Handbook of International Investment Law. Oxford: Oxford University Press, p. 617-636, 2008.

LAFER, Celso. O GATT, a cláusula da nação mais favorecida e a América Latina. Revista de Direito Mercantil, Industrial, Econômico e Financeiro, São Paulo, v. 10, n.3, p. 41$56,1971$.

LEO, Sérgio. Brasil cria modelo de proteção a investidor. Valor Econômico, Brasília, 7 out. 2013. Disponível em: <http://www.valor.com.br/brasil/3295402/brasil-cria-modelode-protecao-investidor>. Acesso em: 2 fev. 2014.

LERNER, Diego Fraga. Os regimes jurídicos de proteção ao investimento estrangeiro direto: o papel desempenhado pelos países emergentes. 2009. 122f. Dissertação (Mestrado em Direito) - Faculdade de Direito da UFRGS, Universidade Federal do Rio Grande do Sul, Porto Alegre. 2009.

LEVY, Daniel de Andrade; BORJA, Ana Gerdau de; PUCCI, Adriana Noemi. Investment protection in Brazil. Alphen aan de Rijn: Wolters Kluwer, 2013.

LEVY, Daniel de Andrade; MOREIRA, Rodrigo. ICSID in Latin America: where does Brazil stand? In: LEVY, Daniel de Andrade; BORJA, Ana Gerdau de; PUCCI, Adriana Noemi. Investment protection in Brazil. Alphen aan de Rijn: Wolters Kluwer, p.17-36, 2013.

LOWENFELD, Andreas F. International economic law. 2th. Oxford: Oxford University Press, 2008. 
LUÍS, Daniel Tavela. Proteção do Investimento Estrangeiro: O Sistema do Centro Internacional para Resolução de Disputas Relativas ao Investimento (CIRDI) e suas Alternativas. 2013. 189 f. Dissertação (Mestrado em Direito) - Faculdade de Direito da Universidade de São Paulo, São Paulo, 2013.

LUMINEAU, Fabrice; MALHOTRA, Deepak. Shadow of the contract: how contract structure shapes interfirm dispute resolution. Strategic Management Journal, v. 32, p.532-555, 2011

MAGAlHÃES, José Carlos de. Acordos Bilaterais de Promoção e Proteção de investimentos. Revista de Informação Legislativa, Brasília, ano 34, n.134, p.13-18, abr./jun., $1997 . \quad$ Disponível em: $<$ http://www2.senado.leg.br/bdsf/bitstream/handle/id/248/r135-02.pdf? sequence=4>. Acesso em: 2 jul. 2014.

2012 .

Direito econômico internacional: tendências e perspectivas. Curitiba: Juruá, O controle pelo Estado da atividade internacional das empresas privadas. Revista de Informação Legislativa, Brasília, v. 30, n. 119, p.175-192, 1993.

MALONEY, Arthur. The ombudsman idea. University of British Columbia Law Review, v. 13, Issue 2, p. 380-400, 1979.

MANN, Howard; VON MOLTKE, Konrad; PETERSON, Luke Eric; COSBEY, Aaron. IISD Model International Agreement on Investment for Sustainable Investment: negotiator's handbook. 2th. Winnipeg: IISD, 2006.

MARSELLI, Riccardo; MCANNON, Bryan C.; VANNINI, Marco. Bargaining in the shadow of arbitration. Journal of Economic Behavior \& Organization, v.117, p.356$368,2015$.

MATIAS, Eduardo Felipe P. O Brasil e os instrumentos internacionais de proteção aos investimentos. Revista de Arbitragem e Mediação, São Paulo, v. 6, n. 21, p. 114-132, 2009.

MELLO, Celso Antônio Bandeira de. Curso de direito administrativo. 27. ed. São Paulo: Malheiros, 2010.

MERRILS, J.G. International dispute settlements. 4.ed. Cambridge: Cambridge University Press, 2005.

MNOOKIN, Robert H.; KORNHAUSER, Lewis. Bargaining in the shadow of the laws: the case of divorce. Yale Law Journal, v. 88, p. 950-997, 1979.

MOROSINI, Fábio; BADIN, Michelle Ratton Sanchez. The Brazilian Agreement on Cooperation and Facilitation of Investments (ACFI): A New Formula for International Investment Agreements? Investment Treaty News. Disponível em: < https://www.iisd.org/itn/2015/08/04/the-brazilian-agreement-on-cooperation-and- 
facilitation-of-investments-acfi-a-new-formula-for-international-investment-agreements/ $>$. Acesso em: 10 ago. 2015.

MUCHLINSKI, Peter T. Multinational enterprises \& the law. 2ed. Oxford: Oxford University Press, 2007.

. Corporate Social Responsibility. In: MUCHLINSKI, Peter; ORTINO, Federico; SCHREUER, Christoph (Coord.).The Oxford Handbook of International Investment Law. Oxford: Oxford University Press, p. 637-687, p. 2008.

. Policy Issues. In MUCHLINSKI, Peter; ORTINO, Federico; SCHREUER, Christoph. (Org.).The oxford handbook of international investment law. Oxford: Oxford University Press, p. 3-48, 2008.

MUCHLINSKI, Peter; ORTINO, Federico; SCHREUER, Christoph (Coord).The Oxford Handbook of International Investment Law. Oxford: Oxford University Press, 2008.

NEUMAYER, Eric; SPESS, Laura. Do bilateral investment treaties increase foreign direct investment to developing countries? London: LSE Research Online, 2005. Disponível em: <http://eprints.lse.ac.uk/archive/00000627>. Acesso em: 02 mai. 2013.

NEWCOMBE, Andrew; PARADELL, Lluís. Law and practice of investment treaties: standards of treatment. The Hague: Kluwer Law International, 2009.

NICOLAS, F., THOMSEN, S; BANG, M. Lessons from Investment Policy Reform in Korea. OECD Working Papers on International Investment, OECD Publishing, p.1-44, 2013. Disponível em: <http://dx.doi.org/10.1787/5k4376zqcpfl-en>. Acesso em: 15 set. 2015.

NUSDEO, Ana Maria de Oliveira. A experiência do decreto $\mathrm{n}^{\circ} 57.943$ como acordo de garantia de investimentos entre Brasil-EUA. In: AMARAL JÚNIOR, Alberto do; SANCHEZ, Michelle Ratton (Cood.) Regulamentação internacional dos investimentos: algumas lições para o Brasil. São Paulo: Aduaneiras, p.303-321, 2007.

NYOUNG, S.; HOOD, N. Designing developmental after-care programmes for foreign direct investors in the European Union. Transnational Corporations, v.3, n.2, p. 45-72, 1994.

ODEBRECHT. Ecuador: Odebrecht Clarifies. Disponível em: $<$ http://www.odebrecht.com/en/node/2649>. Acesso em: 1 jul. 2014.

Odebrecht Infraestrutura - África, Emirados Árabes e Portugal. Disponível em: $<$ http://odebrecht.com/pt-br/negocios/nossos-negocios/infraestrutura-africa-emiradosarabes-e-portugal $>$.

OFFICE OF THE UNITED STATES TRADE REPRESENTATIVE. Chile - United States Free Trade Agreement, Miami, 6 de junho de 2003. Disponível em: $<$ https://ustr.gov/trade-agreements/free-trade-agreements/chile-fta/final-text $>$. Acesso em: 3 nov. 2015. 
. KORUS FTA. Institutional Provisions and Dispute Settlement. Chapter

Twenty-Two.

Disponível

em:

$<$ https://ustr.gov/sites/default/files/uploads/agreements/fta/korus/asset_upload_file973_127

21.pdf $>$. Acesso em: 27 out. 2015.

KORUS FTA. Rules of Procedure for the Joint Committee. Disponível em:

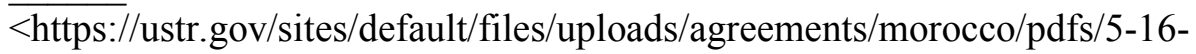

12\%20KORUS\%20Joint\%20Committee\%20Rules\%20of\%20Procedure\%20Final.pdf $>$.

Acesso em: 26 out. 2015.

OLIVEIRA JÚNIOR, Moacir de Miranda (Org.). Multinacionais brasileiras: internacionalização, inovação e estratégia global. Porto Alegre: Bookman, 2010.

OLIVEIRA, Carina Costa de; MONEBHURRUN, Nitish. As implicações de um investimento no setor hidrelétrico equatoriano tiradas da experiência da Odebrecht. Casoteca Direito GV - Produção de Casos, 2011. Disponível em: $<$ http://direitosp.fgv.br/sites/direitosp.fgv.br/files/odebrecht___narrativa.pdf>.

OPPETIT, Bruno. Teoría del arbitraje. Bogotá: Legis, 2006.

ORGANIZATION FOR ECONOMIC CO-OPERATION AND DEVELOPMENT. OECD Reviews of Regulatory Reform KOREA Progress in Implementing Regulatory Reform. OECD Publishing. Disponível em: <http://www.oecd.org/korea/41399033.pdf>. Acesso em: 26 out 2015.

ORREGO VICUÑA, Francisco. International Dispute Settlement in an evolving global society: constitutionalization, accessibility, privatization. Cambridge: Cambridge University Press, 2001. (Hersch Lauterpacht Memorial Lectures).

PANZINI, Fabrizio; NEGRI, Constanza. O retorno dos acordos de investimentos na agenda comercial brasileira. Revista Brasileira de Comércio Exterior, ano 29, n. 123, p. 58-72, abr./jun. 2015.

PARRA, Antonio. The history of ICSID. Oxford: Oxford University Press, 2012.

PENROSE, Edith. A teoria do crescimento da firma. Campinas: Ed. Unicamp, 2006.

PEREIRA, Celso de Tarso. O Centro Internacional para a Resolução de Conflitos sobre Investimentos (CIRDI-ICSID). Revista de Informação Legislativa, Brasília, ano 35, $\mathrm{n}$. 40, p.87-93, out./dez. 1998.

PERRONE, Nicolás M.; CÉSAR, Gustavo Rojas de Cerqueira. Brazil's bilateral investment treaties: More than a new investment treaty model?. Columbia FDI Perspectives Perspectives on topical foreign direct investment issues. n. 159, p.1-3, October 26, 2015. Disponível em: <http://ccsi.columbia.edu/files/2013/10/No-159Perrone-and-C\%C3\%A9sar-FINAL.pdf>. Acesso em: 27 out 2015.

PERRONE-MOISÉS, Claudia. Direito ao desenvolvimento e investimentos estrangeiros. São Paulo: Oliveira Mendes, 1998. 
POLETTI, Arlo; DE BIÈVRE, Dirk; CHATAGNIER, J. Tyson. Cooperation in the shadow of wto law: why litigate when you can negotiate. Working Paper, p. 1-23, 3/2014.

PUCCI, Adriana Noemi. Solução de Controvérsias Relativas a Investimentos Estrangeiros. 2003. 330 f. Tese (Doutorado em Direito) - Faculdade de Direito da Universidade de São Paulo, São Paulo, 2003.

RAMAMURTI, Ravi; SINGH, Jitendra V. Emerging multinationals in emerging markets. Cambridge: Cambridge University Press, 2009.

RAMINA, Larissa. Direito Internacional dos Investimentos. Curitiba: Juruá, 2009.

REED, Lucy; PAULSSON, Jan; BLACKABY, Nigel. Guide to ICSID arbitration. 2nd. Alphen and den Rijn: Kluwer Law International, 2011.

REINISCH, August (Org.). Standards of investment protection. Oxford: Oxford University Press, 2008.

REINISCH, August. Expropriation. In: MUCHLINSKI, Peter; ORTINO, Federico; SCHREUER, Christoph (Coord.).The Oxford Handbook of International Investment Law. Oxford: Oxford University Press, p. 407-458, 2008.

REINISCH, August; KNAHR, Christina. International Investiment Law. Viena: Eleven International Publishing, 2007.

REINISCH, August; MALINTOPPI, Loretta. Methods of dispute resolution In: MUCHLINSKI, Peter; ORTINO, Federico; SCHREUER, Christoph (Coord). The oxford handbook of international investment law. Oxford: Oxford University Press, p. 691-720, 2008 .

RIBEIRO, Marilda Rosado de Sá Ribeiro. As empresas transnacionais e os novos paradigmas do comércio internacional. In: DIREITO, Carlos Alberto Menezes; TRINDADE, Antonio Augusto Cançado; PEREIRA, Antonio Celso Alves (Org.). Novas perspectivas do direito internacional contemporâneo: estudos em homenagem ao professor celso d. de albuquerque mello. Rio de Janeiro: Renovar, p.455-492, 2008.

. Direito Internacional dos Investimentos. Rio de Janeiro: Renovar, 2014.

. Direito dos investimentos e o petróleo. Revista da Faculdade de Direito da UERJ, Rio de Janeiro, v.1, n.18, p.1-37, 2010.

Sovereignty over natural resources investment law and expropriation: the case of Bolivia and Brazil. The Journal of World Energy Law and Business, Oxford, v. 2, n. 2, p. 129-148, July 2009.

RIBEIRO, Marilda Rosado de Sá; XAVIER JÚNIOR, Ely Caetano. Introdução. In: RIBEIRO, Marilda Rosado de Sá. Direito Internacional dos Investimentos. Rio de Janeiro: Renovar, p.1-7, 2014. 
ROCHA, Augusto de Rezende. Parecer DAJ/138: criação de órgão de arbitragem internacional. BIRD, n. 20 ago. 1964.

ROCHA, Valdir de Oliveira. Grandes Questões Atuais do Direito Tributário, v. 19. São Paulo: Dialética, 2015.

RONCOLATTO, Eduardo Lameirão. Investimentos brasileiros diretos no exterior: regime jurídico e perspectivas. 2008. 196 f. Tese (Doutorado em Direito) - Faculdade de Direito da USP, Universidade de São Paulo, 2008.

RUBIN, Edward L. The nonjudicial life of contract: beyond the shadow of the law. Northwestern University Law Review, v. 90, n. 1, p.107-131, 1995.

SALACUSE, Jeswald W.; SULLIVAN, Nicholas P. Do BITs really work? An evaluation of bilateral investment treaties and their grand bargain. Harvard International Law Journal, n. 46, p.67-130, 2005.

SALLES, Carlos Alberto de. Mecanismos alternativos de solução de controvérsias e acesso à justiça: a inafastabilidade da tutela jurisdicional recolocada. In: FUX, Luiz; NERY JR., Nelson; WAMBIER, Teresa Arruda Alvim (Coord.). Processo e Constituição: Estudos em homenagem aos Professor José Carlos Barbosa Moreira. São Paulo: Editora Revista dos Tribunais, p.779-792, 2006.

SALOMÃO FILHO, Calixto. Regulação da atividade econômica: princípios e fundamentos jurídicos. 2. ed. São Paulo: Malheiros, 2008.

SARMENTO, Daniel; IKAWA, Daniela; PIOVESAN, Flávia. Igualdade, Diferença e Direitos Humanos. Rio de Janeiro: Lumen Juris, 2008.

SASSE, Jan Peter. An economic analysis of bilateral investment treaties. Wiesbaden: Gabler, 2011.

SAUVANT, Karl P. (Ed.). Appeals Mechanism in International Investment Disputes, Oxford: Oxford University Press, p.143-192, 2008.

SAUVANT, Karl P. New sources of FDI: the BRICS: Outward fdi from brazil, russia, india and china. The Journal of World Investment \& Trade, Geneva, v. 6, n. 5, p. 639709, 2005.

SAUVANT, Karl P., SACHS, Lisa E. BITs, DTTs and FDI flows: an overview In: SAUVANT, Karl P., SACHS, Lisa E. (Org.). The effect of treaties on foreign direct investment: bilateral investment treaties, double taxation treaties and investment flows. Oxford: Oxford University Press, 2009.

SAUVANT, Karl; ORTINO, Federico. Improving the international investment law and policy regime: options for the future Helsinki. Ministry for Foreign Affairs of Finland, 2013. 
SCHREUER, Christoph. Do We Need Investment Arbitration? In: KALICKI, Jean E.; Joubin-Bret, Anna. Reshaping the Investor-State Dispute Settlement System: Journeys for the 21st Century. Leiden and Boston: Brill Nijhoff, 2015.

SCHREUER, Christoph et al. The ICSID Convention: a commentary. Oxford: Oxford University Press, 2009.

SCANDIUCCI FILHO, José Gilberto. O Brasil e os Acordos Bilaterais de Investimento. In: AMARAL JÚNIOR, Alberto do; SANCHEZ, Michelle Ratton. Regulamentação Internacional dos Investimentos: algumas lições para o Brasil. São Paulo: Aduaneiras, 2007.

SCHLEE, Paula. Transparência em arbitragens internacionais investidor estado. Revista da Secretaria do Tribunal Permanente de Revisão, Assunción, ano 3, n. 5, p.95-113, 2015. p.106. Disponível em: <http://www10.iadb.org/intal/intalcdi/PE/2015/15365.pdf > . Acesso em: 24 mai. 2015.

SCHNEIDER, Andrea K. Bargaining in the shadow of (international) law: what the normalization of adjudication in international governance regimes means for dispute resolution. New York University Journal of International Law and Politics, p.789-822, 2009 .

SCHOUERI, Luís Eduardo; GALENDI JÚNIOR, Ricardo André. Transparência fiscal e reciprocidade nas perspectivas interna e internacional. In: ROCHA, Valdir de Oliveira. Grandes Questões Atuais do Direito Tributário, v. 19. São Paulo: Dialética, p. 248-287, 2015.

SCHRIJVER, Nico. Sovereignty over natural resources: balancing rights and duties. Cambridge: Cambridge University Press, 1997.

SCHWARZENBERGER, Georg. The Fundamental Principles of International Law. Recueil des cours, n. 87, p.181-395, 1955.

SENNES, Ricardo. La inserción económica internacional de Brasil: desafio del gobierno de dilma Rousseff. Revista CIDOB d'afers internationals, n. 97-98, p.151-173, abr. 2012 .

SHAN, Wenhua; GALLAGHER, Norah. China. In: BROWN, Chester (Ed.). Commentaries on selected model investment treaties. Oxford: Oxford University Press, p.131-181, 2013.

SHIN, Hi-Taek. Republic of Korea In: BROWN, Chester (Ed.). Commentaries on selected model investment treaties. Oxford: Oxford University Press, p. 393-424, 2013.

SILVA, Caio Carlos Cruz Ferreira. O regime jurídico brasileiro de tratamento e proteção dos inventimentos internacionais diretos. 2007. 347f. Dissertação (Mestrado em Direito) - Faculdade de Direito da USP, Universidade de São Paulo, São Paulo, 2007. 
SILVA, Silas Thomaz da. Padrões de inserção do Brasil nas cadeias globais de valor: uma análise do investimento direto estrangeiro no país no período de 2003-2012. Boletim de Economia e Política Internacional, n.15, p.47-81, set./dez. , 2013.

SILVEIRA, Eduardo Teixeira. A disciplina jurídica do investimento estrangeiro no Brasil e no direito internacional. São Paulo: Juarez de Oliveira, 2002.

SMITH, Stephanie; MARTINEZ, Janet. An analytic framework for disputes systems design. Harvard Negociation Law Review, v. 14, p.123-169, 2009.

SORNARAJAH, M. The international law on foreign investment. New York: Cambridge University Press, 1994.

. The international law on foreign investment. 2nd. New York: Cambridge University Press, 2004.

. The International Law of Foreign Investment. 3rd. New York: Cambridge

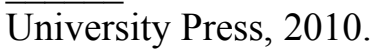

SOUZA, Renato Rezende de Campos. Cooperation and Facilitation Investment Agreement - CFIA. [apresentação de slides no World Investment Forum]. [s.l.], mai 2015. Disponível em: <http://unctad-worldinvestmentforum.org/wpcontent/uploads/2015/03/Brazil_side-event-Wednesday_model-agreements.pdf $>$. Acesso em: 15 set. 2015.

SOUZA, Washington Peluso Albino de. Direito Econômico. São Paulo: Saraiva, 1980.

TEIXEIRA, Egberto Lacerda. Regime jurídico-fiscal dos capitais estrangeiros no Brasil. Revista Forense, Rio de Janeiro, v. 248, 1974. p.456.

TELLI, Isadora Postal. Investimento estrangeiro e meio ambiente: uma análise sobre o tratamento das questões ambientais suscitadas nos casos decididos pelo ICSID entre 2000-2013. 2015. 188 f. Dissertação (Mestrado em Direito) - Faculdade de Direito, Universidade de São Paulo, São Paulo, 2015.

THE BOSTON CONSULTING GROUP. The new global challengers: how 100 top companies from rapidly developing economies are changing the world. Disponível em: $<$ http://www.bcg.com.cn/export/sites/default/en/files/publications/reports_pdf/New_Global _Challengers_May06.pdf $>$. Acesso em: 10 jul. 2014.

THORSTENSEN, Vera. OMC Organização Mundial do Comércio: As regras do comércio internacional e a nova rodada de negociações multilaterais. São Paulo: Aduaneiras, 2001.

TIBÚRCIO, Carmen. A arbitragem no direito brasileiro: histórico e lei 9.307/96. Revista de Processo, São Paulo, v. 104, p.79-99, 2001.

. Arbitragem de investimento no Brasil In: RIBEIRO, Marilda Rosado de Sá (Org.)

Direito Internacional dos Investimentos. Rio de Janeiro: Renovar, p. 233-270, 2014. 
TOURME-JOUANNET, Emmanuelle. What is a fair international society?: international law between development and recognition. Oxford; Portland: Hart Publishing, 2013.

TRATADO entre o governo da República da Indonésia e o governo da Repúbica de Moçambique para a promoção e proteção de investimentos. Maputo, 26 de março de 1999. Disponível em: <http://investmentpolicyhub.unctad.org/Download/TreatyFile/1628>. Acesso em: 29 set. 2015.

UNITED NATIONS. Draft articles on diplomatic protection with commentaries. Geneva: United Nations, 2006. Disponível em: $<$ http://legal.un.org/ilc/texts/instruments/english/commentaries/9_8_2006.pdf $>$.

UNITED NATIONS COMMISSION ON INTERNATIONAL TRADE LAW. Arbitration Rules. Disponível

em: $<$ http://www.uncitral.org/uncitral/en/uncitral_texts/arbitration/2010Arbitration_rules.html. Acesso em: 30 set. 2015.

. Origin, Mandate and Composition of UNCITRAL. Disponível $\overline{\mathrm{em}:}<$ http://www.uncitral.org/uncitral/en/about/origin.html $>$. Acesso em: 30 set. 2015.

UNITED NATIONS CONFERENCE ON TRADE AND DEVELOPMENT. Bilateral Investment Treaties 1995-2006: Trends in Investment Rulemaking. New York; Geneva: United Nations, 2007. Disponível em: <http://unctad.org/en/docs/iteiia20065_en.pdf>. Acesso em: 30 jun. 2014.

. Fair and equitable treatment. UNCTAD Series on issues in international investment agreements II. New York and Geneva: United Nations, 2012.

International investment agreements: key issues. New York; Geneva: United Nations: 2005. $\quad$ v.3. $\quad$ p. 2 2. Disponível em: $<$ http://unctad.org/en/Docs/iteiit200410v3_en.pdf>. Acesso em: 30 jun. 2014.

: Investment Policy Hub. Disponível em:

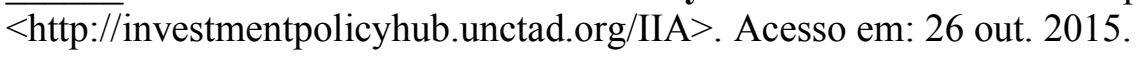

- Investment policy monitor. n. 14, October 2015. Disponível em:

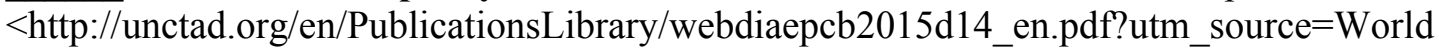
+ Investment+Network+\%28WIN\%29\&utm_campaign=1daa03da05-

Blog + Post $+\% 231 \& u t m \_$medium $=$email\&utm_term=0_646aa30cd0-1daa03da0570020601>. Acesso em: 20 ago. 2014.

Investor-State dispute settlement: UNCTAD Series on issues in international investment agreements II. New York and Geneva: United Nations, 2014. Disponível em: $<$ http://unctad.org/en/PublicationsLibrary/diaeia2013d2_en.pdf $>$. Acesso em: 3 out. 2015.

National Treatment: UNCTAD Series on issues in international investment agreements. New York; Geneva, 1999. 
Proceedings of the Washington and Lee University and UNCTAD. Joint Symposium on international investment and alternative dispute resolution, held on 29 March 2010 in Lexington, Virginia, United States of America. New York; Geneva: United Nations, 2011.

. Recent trends in IIAs and ISDS, n.1. Genebra: United Nations, 2015.

Series on International Investment Policies for Development. Investor-State Disputes: Prevention and Alternatives to Arbitration. New York and Geneva: United Nations, 2010.

. The entry into force of bilateral investment treaties (BITs). IIA MONITOR. New York; Geneva: United Nations, 2006. n. 3. Disponível em: $<$ http://bit.escwa.org.lb/CMSPages/GetFile.aspx?nodeguid=6f33da83-a49d-48fb-8c0da6eec1a0b62e>. Acesso em: 29 jun. 2014.

. World Investment Forum 2014: investing in sustainable development. IIA Conference - 16 October 2014. Daniel Godinho. Disponível em: <http://unctadworldinvestmentforum.org/wp-content/uploads/2014/10/Godinho.pdf $>$. Acesso em: 16 dez. 2014.

World investment Report 2012: towards a new generation of investment policies. Genebra: ONU, 2012. Disponível em: < http://www.unctad-docs.org/UNCTADWIR2012-Full-en.pdf>. Acesso em: 02 mai 2014.

. World Investment Report 2013: Global value chains: investment and trade for development. New York; Genebra: ONU, 2013. Disponível em: $<$ http://unctad.org/en/PublicationsLibrary/wir2014_en.pdf>. Acesso em: 30 jun 2014.

. World Investment Report 2014: Investing in the SDGs: an action plan. New York; Genebra: ONU, 2014. Disponível em: $<$ http://unctad.org/en/PublicationsLibrary/wir2014_en.pdf $>$. Acesso em: 26 jun 2014.

. World Investment Report 2015: Reforming international investment governance. New York; Geneva: United Nations, 2015.

UNITED STATES OF AMERICA. Treaty between the United States of America and the Oriental Republic of Uruguay concerning the encouragement and reciprocal protection of investment. Disponível em: $<$ https://ustr.gov/sites/default/files/uploads/agreements/bit/asset_upload_file748_9005.pdf >. Acesso em: 7 nov. 2015.

URBAN, Tatiana Proença. O processo de internacionalização de uma multinacional brasileira. 2006. 106 f. Dissertação (Mestrado em Administração) - Faculdade de Economia, Administração e Contabilidade, Universidade de São Paulo, São Paulo, 2006.

URY, William; BRETT, Jeanne; GOLDBERG, Stephen. Resolução de Conflitos. Lisboa: Actual Editora, 2009. 
VALE. VALE no mundo. Disponível em: $<$ http://www.vale.com/mozambique/PT/aboutvale/across-world/Paginas/default.aspx $>$. Acesso em: 18 nov. 2014.

VAN HARTEN, Gus. Investment Treaty Arbitration and Public Law. Oxford: Oxford University Press, 2007.

VANDEVELDE, Kenneth J. A brief history of international investment agreements, U.C. Davis. Journal of International Law \& Policy, California, v. 12, n. 1, p. 157-194, 2005.

VEIGA, Pedro da Motta. A África na agenda econômica do Brasil. Comércio, investimentos e cooperação. Revista Brasileira de Comércio Exterior. ano 27, n. 116, p. 4-19, jul./set. 2013.

VEIGA, Pedro da Motta; RIOS, Sandra Polónia. Os investimentos brasileiros no exterior: características, motivações e agenda de políticas. Revista Brasileira de Comércio Exterior, Rio de Janeiro, ano 28, n.118, jan./mar. 2014.'

VERBEKE, Alain. Negotiating [in the shadow of a] European Private Law. Maastricht Journal of European and Comparative Law, v. 15, p.395-413, 2008.

VILLAS-BÔAS, Júlia Covre. Os investimentos brasileiros na África no governo Lula: um mapa. Meridiano 47, v.12, n. 128, nov./dez. 2011.

VIÑUALES, Jorge E.; LANGER, Magnus Jesko. Foreign Investment in Latin-America: between love and hatred.In: AUROI, Claude (Ed.). Latin-America: dreams and legacy, 2010. Disponível em: <http://ssrn.com/ abstract=1652736>. Acesso em: 3 fev. 2015.

VOSS, Jan Ole. The impact of investment treaties on contracts between host states and foreign investors. Leiden and Boston: Martinus Nijhoff Publishers, 2011.

WALD, Arnoldo. A evolução do regime constitucional da parceria público-privada e do capital estrangeiro. Revista de Informação Legislativa, Brasília, v.45, n.179, p. 403-410, 2008 .

. Uma nova visão dos tratados de proteção de investimento e da arbitragem internacional. Revista de Arbitragem e Mediação, São Paulo, v.6, n.21, p.9-29, 2009.

WIEGAND, Shirley A. A Just and Lasting Peace: Supplanting Mediation with the Ombuds Model. Ohio State Journal on Dispute Resolution, v. 12, n. 1, p. 95-145, 1996.

WILLIAMSON, Peter J., RAMAMURTI, Ravi, FLEURY, Afonso e FLEURY, Maria Tereza Leme. The competitive advantage of emerging Market multinationals. Cambridge: Cambridge University Press, 2013.

WORLD TRADE ORGANIZATION. Trade Policy Review: Angola. Geneva, 18 ago 2015 .

. Trade Policy Review: Republic of Korea. Geneva, 15 ago. 2012. 
XAVIER JÚNIOR, Ely Caetano. Direito internacional dos investimentos e o Brasil: uma perspectiva a partir do padrão de tratamento justo e equitativo. $2014.279 \mathrm{f}$. Dissertação (Mestrado em Direito) - Faculdade de Direito da Universidade Estadual do Rio de Janeiro, Rio de Janeiro, 2014.

ZERBINI, Eugenia C.G. de Jesus. O regime internacional dos investimentos - sistemas regional, multilateral, setorial e bilateral (balance da década de 1990, seguido do estudo de dois casos: o Mercosul e o projeto da ALCA). 2003. 250 f. Tese (Doutorado em Direito) - Faculdade de Direito, Universidade de São Paulo, São Paulo, 2003.

ZERBINI, Eugenia. O Brasil à distância do direito internacional dos investimentos. Revista de Direito Bancário e do Mercado de Capitais, n. 35, ano 10, p.11-18, jan./mar., 2007.

ZERBINI, Eugenia C.G.. Regras multilaterais sobre o investimento internacional. In: AMARAL JÚNIOR, Alberto do; SANCHEZ, Michelle Ratton (Coord.) Regulamentação internacional dos investimentos: algumas lições para o Brasil. São Paulo: Aduaneiras, p. 125-149, 2007.

ZIEGLER, Andreas R. Most-favoured-nation (MFN) treatment. In: REINISCH, August (Org.). Standards of investment protection. Oxford: Oxford University Press, p. 59-86, 2008 .

ZIEGLER, Andreas R., GRATTON, Louis-Philippe. Investment assurance. In MUCHLINSKI, Peter; ORTINO, Federico; SCHREUER, Christoph. (Org.).The oxford handbook of international investment law. Oxford: Oxford University Press, p.524-548, 2008 . 